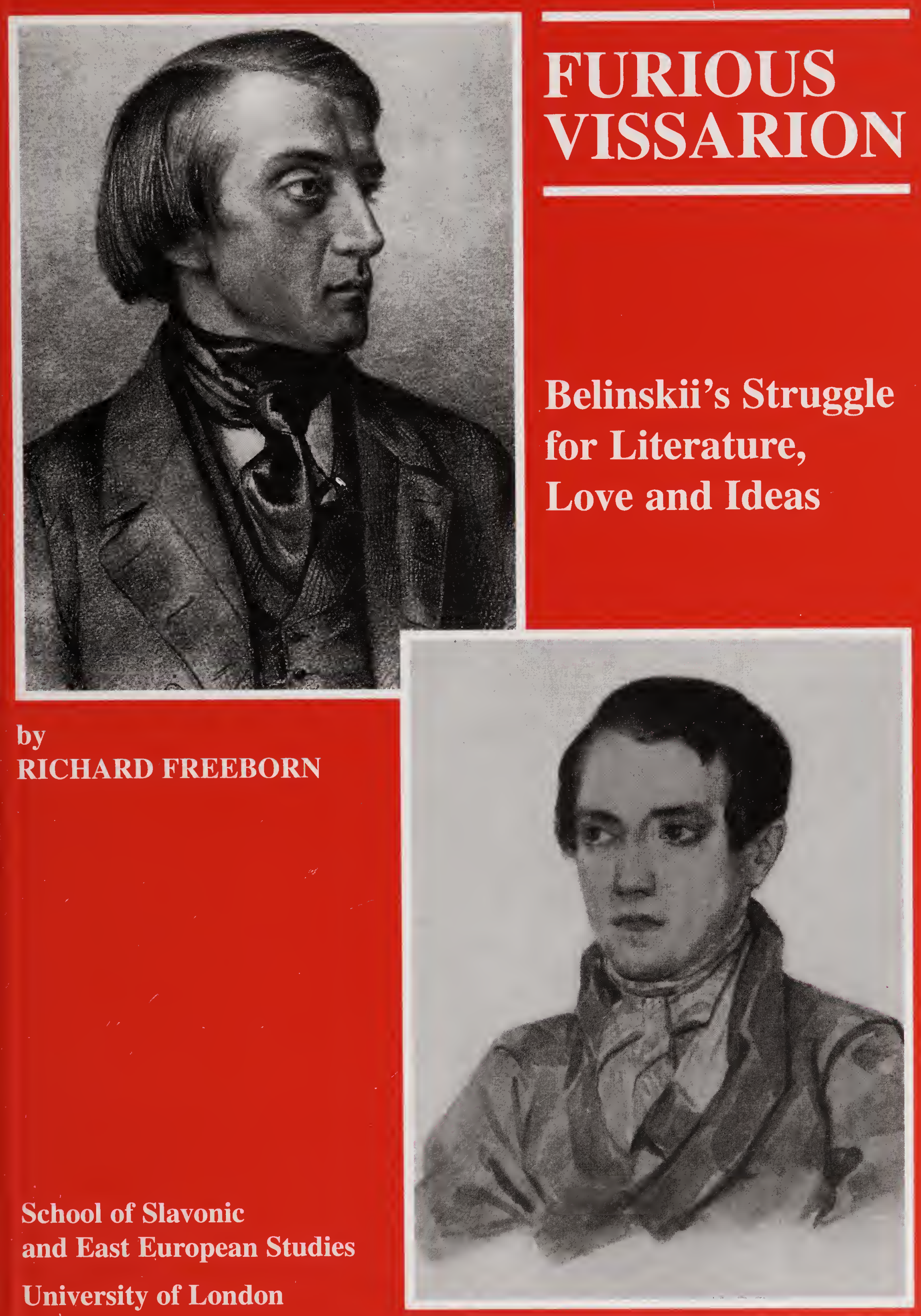


Digitized by the Internet Archive in 2019 with funding from

UCL School of Slavonic and East European Studies (SSEES)

https://archive.org/details/SSEES0025 


\section{FURIOUS VISSARION \\ Belinskii's Struggle for Literature, \\ Love and Ideas}

by

RICHARD FREEBORN 


\section{Also by Richard Freeborn \\ (MA DPhil DLitt, Emeritus Professor of Russian Literature, University of London)}

Monographs: Turgenev, The Novelist's Novelist A Short History of Modern Russia

The Rise of the Russian Novel

The Russian Revolutionary Novel

Translations: Ivan Turgenev, Sketches from a Hunter's Album; Ivan Turgenev, Home of the Gentry; Ivan Turgenev, Rudin; Ivan Turgenev, First Love and Other Stories; Ivan Turgenev, A Month in the Country; Ivan Turgenev, Fathers and Sons; Fyodor Dostoevsky, An Accidental Family.

Editor/Contributor: Russian Literary Attitudes from Pushkin to Solzhenitsyn (with Georgette Donchin and N.J. Anning); Russian and Slavic Literature (with R.R. Milner-gulland and Charles A. Ward); The Age of Realism (ed. F.W.J. Hemmings); The Cambridge History of Russian Literature (ed. Charles A. Moser); Ideology in Russian Literature (with Jane Grayson); Encyclopedia of the Novel (2 vols., ed. Paul Schellinger); Reference Guide to Russian Literature (ed. Neil Cornwell); The Cambridge Companion to Tolstoy (ed. Donna Tussing Orwin).

Novels: Two Ways of Life; The Emigration of Sergey Ivanovich; Russian Roulette; The Russian Crucifix. 


\section{FURIOUS VISSARION \\ Belinskii's Struggle for Literature, \\ Love and Ideas}

by

RICHARD FREEBORN 


\section{FURIOUS VISSARION}

BELINSKII'S STRUGGLE FOR LITERATURE, LOVE AND IDEAS

\section{BY RICHARD FREEBORN}

(C) School of Slavonic and East European Studies 2003

SSEES Occasional Papers No. 58

ISBN: 0903425-69-6

The right of Richard Freeborn to be identified as the author of this work has been asserted by him.

All rights reserved. No part of this publication may be stored in a retrieval system or transmitted in any other form or by any means, electronic, mechanical, recording or otherwise, without prior permission of the School of Slavonic and East European Studies.

Copies of this publication can be obtained from the Publications Office, SSEES, Senate House, Malet Street, London WCIE 7HU. 
'One has often heard it said that so-and-so died at the right time... But to no one does this apply more than to Belinskii. Yes, indeed, he died at the right time! Before his death (Belinskii died in May 1848) he managed to witness the triumph of his most cherished hopes and did not live to see their final defeat... Yet the misfortunes awaiting him if he had lived! It is well known that the police made daily inquiries about his health, about the agony of his dying... Death relieved him of painful torments. In any case, his physical side gave up... What point was there in going on, in prolonging it?

" "One struggle more, and I am free." [Byron]

'That is true, but the living think in terms of what is alive, and one cannot suppress a feeling of regret for those of us whom death has carried off into "the undiscover'd country from whose bourn No traveller returns..."

Ivan Turgenev, 'Reminiscences of Belinskii,' 1869 



\section{Contents}

Preface ix

Introduction 1

Chapter 1 The Early Years: Dmitrii Kalinin 9

$\begin{array}{lll}\text { Chapter } 2 & \text { From Literary Reveries to Hamlet } & 17\end{array}$

Chapter 3 From Hamlet to Reconciling the Real 33

Chapter $4 \quad$ St Petersburg, Fatherland Annals and A Hero of Our Time $\quad 51$

Chapter 5 From Socialism to Dead Souls 63

$\begin{array}{lll}\text { Chapter } 6 & \text { Turgenev, Love and Romanticism }\end{array}$

$\begin{array}{lll}\text { Chapter } 7 & \text { Love Letters to Marie } & 87\end{array}$

Chapter 8 The Role of Literature and the Study of Pushkin 105

Chapter 9 The Discovery of Dostoevskii 125

Chapter 10 The Journey to the South and the Letter to Gogol 135

Chapter 11 Paris, Last Reviews and Death 159

$\begin{array}{ll}\text { Conclusion } & 179\end{array}$

Explanatory List of Little-known Russian Personalities 191

Select Bibliography 197

$\begin{array}{ll}\text { Index } & 201\end{array}$ 



\section{Preface}

A personal note must be struck to start with. I make no apology for using Soviet sources. This applies especially to V.S. Nechaeva's supposedly 'Stalinist' 4-vol. biography of Belinskii (1949-67). It is the only full-scale treatment of Belinskii's life and work and a piece of valuable research in its own right which outlived its Stalinist past during the period of its composition.

My aim in this study has been to rid Vissarion Belinskii's reputation, both Soviet and pre-Soviet, of the myths accruing to it and the spurious, politically correct adulation accorded to it during the Soviet period. For this purpose I have sought to do three things. They are suggested in the subtitle. I have sought to describe Vissarion Belinskii's struggle to 'discover' a Russian literature worthy to be considered part of contemporary European literature, to highlight the role played by love, both personal and intellectual, in this struggle, and to show how he struggled to create for himself an ideal out of the various currents of ideas prevalent in his time. If this study can be regarded as a biography, then it is principally a biography of Belinskii as a literary critic.

I have to express a very warm debt of thanks to Professor Derek Offord who was kind enough to appraise this work very positively when submitted to him and I have altered and expanded it largely on the basis of his close reading and valuable suggestions. I am also indebted to George Kolankiewicz and Christine Fernandes of the School of Slavonic and East European Studies, University College, London for their help in ensuring its eventual publication under the SSEES imprint.

$* * *$

The transliteration of Russian names, titles and texts in this study is based on the Library of Congress system with the acknowledgement of soft signs by inverted commas. The fracturing of names in reasonably common use (e.g. Olga) has been avoided. Gogol in the possessive form has become Gogol's without acknowledgement of the final soft sign.

All translations of Russian titles and texts are my own unless otherwise indicated.

All titles of major prose works and journals have been italicised. Italics have also been used for the titles of narrative poems, major works of drama and noteworthy reviews. Other titles (e.g. of articles, short poems, reviews, etc.) have been enclosed by inverted commas. 
Where a place of publication is unclear, publisher's details have been given. All quotations from Belinskii's published works and correspondence derive from V.G. Belinskii, Polnoe sobranie sochinenii, Vols. I XII, M., 1953-6, the definitive Academy of Sciences edition. Bracketed volume and page number in the text refer to this source.

Moscow has been shortened to M. as a place of publication, St Petersburg (pre-1914 and post-1991) to Spb.

Vosp. sov. + page number refers to V.G. Belinskii v vospominaniakh sovremennikov. Seria literaturnykh memuarov. M., 1977.

Pss. has been used as an abbreviation to indicate Polnoe sobranie sochinenii $[$ i pisem].

Parts of this study have been given as papers at the universities of Cambridge, London and Bristol, and a version of sections from Chapters 5 and 7 has appeared as 'Belinskii, Romanticism and Reality' in The Slavonic and East European Review, Vol. 77, No 2, April 1999, pp. 269-79. Part of Chapter 8 is published separately, in a slightly altered form, as 'Belinskii and Pushkin' in Pushkin's Legacy, Rodopi (Amsterdam and Atlanta, GA), 2001.

An 'Explanatory List of Little-known Russian Personalities' has been appended at the end to aid understanding of the literary background. 


\section{Introduction}

Vissarion Grigor'evich Belinskii (1811-48) has long been acknowledged as Russia's greatest literary critic, the 'discoverer' of Dostoevskii, for instance, author of the famous Letter to Gogol, friend of Herzen and Turgenev, founding member of the Russian intelligentsia, prominent advocate of the West and a moral influence extending far into the nineteenth and twentieth centuries. None of this was achieved without a struggle, as Turgenev intimated in his Reminiscences by quoting from Byron. ${ }^{1}$

Belinskii struggled to find Russian literature as he struggled to find love and ideas. The voluminous correspondence with friends gave rise to masterpieces of confessional writing which posed questions about love for each other as well as love for ideas and he wrote love-letters of remarkable honesty, passion and petulance to his future wife. He struggled to assimilate new ideas from the West, was mystified and infatuated by them, in the end largely repudiated them and yet never abandoned his commitment to a new and idealistic vision of Christ. ${ }^{2}$ His struggle for love has been obscured by the prominence given to his ideological struggle, which has in turn tended to obscure the Christian idealism at the heart of his thinking and the fact that literature was his principal concern to which all other considerations were subordinate.

Belinskii's role as a literary critic has of course become tarnished. Known as 'furious' or 'ferocious' Vissarion (neistovyi Vissarion) for the intensity with which he expressed his ideas, his enmities and his convictions, he has suffered in terms of reputation from the handicap of being considered more a moral teacher than a flesh-and-blood human

1 Turgenev misquoted Byron's poem of $1811-12$ by writing 'A struggle more and I am free!' Vosp. sov. p. 512.

2 The work of Ivanov-Razumnik, V.G. Belinskii, Petrograd, 1918, laid stress on Belinskii's Christianity but was subsequently condemned by Soviet criticism. 
being. As Annenkov put it: 'A sketch of his moral teaching throughout the length of his life would be his real biography, ${ }^{3}$ and this has formed the common practice of virtually every approach to Belinskii. He was largely denied a life, in the sense of a biography, unless it was manifestly 'popular' and angled to read like a secular hagiography. ${ }^{4}$ Far worse, his name - Vissarion - suffered the notoriety of being Joseph Stalin's patronymic: Vissarionovich, and led to him being 'canonised', as Isaiah Berlin put it. ${ }^{5}$ Cast in bronze as a revolutionary democrat, he was transformed as a literary critic into one who wrote tablets of the law designed to promote orthodoxy within the narrow framework of socialist realism.

In fact, Vissarion Belinskii was more passionate, furious, tragic and complex than the conventional luminous image of him as moral teacher ever allowed. At the heart of his literary criticism was a profound love of the very compulsion that led to literary creativity. In defining it in relation to Pushkin's work - and his study of Pushkin was his single greatest critical achievement - he resorted to the term pathos 6 to describe it and used Shakespeare to illustrate it, particularly in relation to Hamlet:

'Pathos turns the simple mental understanding of an idea into love for the idea, a love full of energy and passionate striving. In philosophy the idea is disembodied; through pathos it is turned into action, into real fact, into living being. From the word pathos derives the word pathetic (pathétique), ${ }^{7}$ mostly used in relation to dramatic poetry as being the fullest example of pathos in its essence. But we would rather explain the meaning of pathos by indicating it in great works of art... The pathos of Hamlet is the struggle between discontent over vice and crime and a powerlessness to enter into open, uninhibited conflict with them as a sense of duty demands... How many reasons there are for Hamlet to take

3 P.V. Annenkov, Literaturnye vospominaniia, Gos. izd. khud. lit, 1960, p. 192.

4 One example of a semi-fictional recreation of Belinskii's life was Lev Slavin's Neistovyi: povest' o Vissarione in the series Plamennye revoliutsonery, M., 1973.

5 Isaiah Berlin, Russian Thinkers, London, The Hogarth Press, 1978, p. 185.

6 Belinskii's use of the term probably derives from Hegel. As Victor Terras has claimed: 'Belinskii's usage of pafos definitely coincides with Hegel's.' Victor Terras, Belinskii and Russian Literary Criticism: The Heritage of Organic Criticism, Madison, 1974, p. 136. The extent to which Belinskii was a devotee of Hegel at the time he used the term in this context (1844) must be in doubt.

7 The French word has been given in brackets to indicate the meaning more fully. 
terrible and implacable revenge for the flouting of his rights, for the sin of regicide and fratricide, for his mother's vice, for a crown stolen so basely, for goodness' sake, for majesty's sake, for his own sake!... He knows what he ought to do, what fate has summoned him to do - and he shies away from the deed expected of him, blanches before the summons, procrastinates and in shameful indecision merely talks instead of acting. But if his will is weak, his spirit is as great as it is pure. He is aware of this and with what passion and bitterness he expresses his self-loathing in those long monologues which, as soon as he is alone and the hitherto suppressed feelings are given their head, are torn from him like an enormous river scattering the spring ice before it and flooding the surrounding lands... These emotion-filled monologues express the full pathos of the tragedy, they show forth the inner eccentric force which made the poet take up his pen to relieve his own soul of the burden weighing upon it...8 (VII, 313)

This readiness in terms of feeling to go beyond sympathy or even empathy in understanding what compelled a writer or poet to seek to 'relieve his own soul of the burden weighing upon it' was ultimately what Belinskii meant by criticism at its finest and most intuitive. Influenced though he was by the attitudes and terminolgy of German romantic ideas, by Schelling, Fichte and Hegel, he was never enslaved to them, indeed outgrew and transcended them and brought to an understanding of ideas precisely that pathos referred to above, which turned understanding of an idea into love for the idea, a love full of energy and passionate striving. Isaiah Berlin perceived this in his essay on the critic when he wrote:

'His unique quality as a literary critic, the quality which he possessed to a degree scarcely equalled by anyone in the west, is the astonishing freshness and fullness with which he reacts to any and every literary impression, whether of style or of content, and the passionate devotion and scruple with which he reproduces and paints in words the vivid original character, the colour and shape, above all the moral quality of his direct impressions. His life, his whole being, went into the attempt to seize the essence of the literary experience which he was at any given moment trying to convey."

There was in Belinskii's devotion to his subject a passion for experiencing literature that was often more passionate than wise. He loved

8 From article 5 of 'The Works of Alexander Pushkin', Fatherland Annals, 1844.

9 Isaiah Berlin, op. cit., p. 162. 
literature, true, and was often carried away by praise for the mediocre if he felt he could detect in it something of his own passion. He also despised the pretentious, the overblown, the sugared pill of literature and brought all his contemptuous ferocity to bear upon it when necessary.

There was a passion also in his friendships to which his correspondence often attested. The act of letter-writing was a deeply honest, confessional, therapeutic process for him. He was right when he claimed that all his life was in his letters. His entire capacity for love was expressed at its most articulate and desperate in the twenty or so letters he wrote to his future wife in September and October 1843, just as his anger at Gogol's betrayal of the ideals he revered so greatly in his concern for Russian literature was so unbridled and fierce in his famous Letter to Gogol. Love and anger as emotional extremes were the foremost ingredients of his passion. Though it fed upon ideas, his was a passion that achieved its truest expression in a vision of justice and freedom first intimated in his student drama Dmitrii Kalinin and his earliest work In essence, of course, Annenkov was right: Belinskii's moral stance was of a piece from the beginning to the end. But that was not the sum total of his life.

There is no denying that his attack on Gogol, whom he greatly respected as Russia's leading writer and liked to think of as a friend, was the greatest of his achievements, personally anguishing though it was and terrible in its unforeseen consequences. That it became a sacred text of the Russian intelligentsia and among the founding documents of Russian socialism did not make it any less personal as a last will and testament. There is equally no denying that for all his idealism, his integrity, his courage and thirst for truth there was in his legacy, as Derek Offord has acutely noted, 'a proclivity to schematic generalisation, intolerance and scorn for moderation, a tendency to stretch material on a Procrustean bed of theoretical abstraction, and a willingness to follow ideas remorselessly to conclusions from which there might flow evil, oppression and injustice no more tolerable than those to whose eradication Belinskii's short life was dedicated.' 10 This, the unforgiving destiny of so much idealism, has certainly overshadowed Belinskii's reputation. It may even have unfairly

10 Derek Offord, 'Vissarion Grigor'evich Belinsky (30 May 1811 - 26 May 1848),' in Russian Literature in the Age of Pushkin and Gogol: Prose, ed. Christine A. Rydel (Dictionary of Literary Biography, Vol. 198), Bruccoli Clark Layman, Gale Research, London, 1999, p. 53. 
obscured the man himself from view in the two English monographs devoted to him. ${ }^{11}$

In emphasising the struggle for literature, love and ideas, this study of Belinskii is designed to reveal the man as well as the critic, but it cannot lay claim to be a biography in a conventional sense. So many of the details of his boyhood, adolescence and student years, despite energetic research during the Soviet period, have been clouded by speculation, bias and inaccuracy. ${ }^{12} \mathrm{He}$ was himself reluctant to mention more than snippets about his early life; as for the published correspondence of his maturity, at some stage sections appear to have been erased. ${ }^{13}$ Memoir material, though copious in illuminating his last years, was often composed many years after his death and must necessarily be treated with care. He was also very shy in company, keen on personal privacy and only ready to share confidences with a small group of his most intimate friends. The most fully documented were his St Petersburg years, approximately from

11 Both were concerned principally with Belinskii as literary critic and the evolution of his ideas. That by Herbert E. Bowman - Vissarion Belinskii, 1811-1848: A Study in the Origins of Social Criticism in Russia, New York, 1954 - was mainly a straightforward, chronological account of the stages through which Belinskii's critical opinions evolved, copiously illustrated with translated extracts. The work by Victor Terras (see note 4 above) was a brilliant, wide-ranging, erudite study of various aspects of Belinskii's achievement as a critic, particularly valuable for its treatment of his legacy. Disregard of biographical background and chronology tended to fragment the picture of his organicist criticism which was the study's main object; yet it has remained the most enriching and analytical of monographs in English devoted to Belinskii and this study does not seek to rival it. Also extremely valuable is Sigurd Fasting's V.G. Belinskij: Die Entwicklung seiner Literatur Theorie I: Die Wirklichkeit ein Ideal, Scandinavian University Books, Universitetsforlaget, Oslo-Bergen-Tromso, 1972, although it does not carry the study of Belinskii's ideas beyond 1840 . The most valuable and comprehensive of Russian studies is the 4-volume biography by V.S. Nechaeva published between 1949 and 1967 (as mentioned in the Preface). It suffers from the Soviet habit of tending towards hagiography at the expense of the canonically unpalatable. Other significant works on Belinskii are listed in the Select Bibliography.

12 The first volume of Nechaeva's biography, with its genuflections to Lenin and Stalin, gave a well-documented picture of the circumstances of Belinskii's early life without revealing much of value about his upbringing. Her 4-volume work concentrated on the critic's life and work prior to his departure for St Petersburg in 1839 and tended to be less exhaustive in its treatment of the period when he achieved his greatest fame.

13 These deletions seem to have occurred mostly in intimate correspondence with men friends, particularly 'Michel' Bakunin and Vasilii Botkin, and can lead to the suspicion that they contained scandalous, presumably sexual, references. 
$1839-48$, and it is upon these that this study has concentrated. His life was in any case a struggle due to tuberculosis, poverty, underprivileged social background, unsociability and the endless treadmill of critical work.

It was of course a life lived for love of words, love of humanity and surprising though it may be to assert it - love of God. Not, of course, the God of the Orthodox Church. Belinskii wrote candidly about God, his image of the deity and his commitment to Christ and Christian teaching on many occasions, but his was a very personal, humanistic, utopian God and a pre-Pauline Christ with few disciples and no church. To deny such presences in his life must be to do a disservice to his idea of justice and the role of literature in achieving such justice in Russian society. He wrote po povodu, a propos, within, that is to say, the broad confines of the literary work under review, always aware that he had a duty to his readership to describe the work while appraising it in terms of its moral and artistic worth. This was often subjective, sometimes manifestly biassed, sometimes wrongheaded; yet what is remarkable is how frequently he was right and how frequently his judgment came to be accepted as valid for later generations as well as his own. He wrote out of a growing conviction that literature should have a social purpose and tended to beat this drum too loudly, to the detriment of common sense - never, though, to the detriment of the sincerity which he brought to the conviction. This sincerity encompassed his morality and was essential to his passion; it breathed life into his words; it lifted what he wrote from prosaic exegesis into a fierce colloquy that inspired countless minds to query, re-assess and re-think.

He was genuinely loved and respected by many friends, among the most famous of them being Herzen, Turgenev, Goncharov, Dostoevskii, Annenkov and Botkin. He was loved because he cherished their friendship, recognised they were a precious asset to Russia in its embryonic intellectual state, argued with them and encouraged them; and out of that love and friendship sprang a concept of personality, expressed in Russian by the term lichnost', which was to form the moral and intellectual basis for the classless meritocracy now known as the Russian intelligentsia. This concept of personality was in large part Belinskii's legacy. It became altered, distorted and lost in later generations, under the weight of MarxEngels-Lenin-Stalinism. Because it was based too obviously on respect for individual freedom and belief in justice, and because Belinskii himself assumed in an often preacherly, sermonising fashion that love for others should always be superior to egoism, that it should always be a defining factor in human morality, his concept of personality came to seem too general and idealistic for an intelligentsia intent on finding easily 
assimilable political answers. Belinskii himself agonised all his life over the complexity of such matters and was never content with theory.

He sought initially for role models or human exemplars. This was inseparably part of his search for a guiding idea. The first such exemplar was Shakespeare's Hamlet, whom he did not so much emulate as employ as a mirror to his own condition and whose idealism he endeavoured to reconcile with reality through the study of Hegel. Another such exemplar was Lermontov and his hero Pechorin. More profoundly and maturely he looked for an ideal in Pushkin and his major achievements. Throughout his life he admired and revered the achievement of Peter the Great in turning Russia towards the West. These may be construed as steppingstones on a path to self-realisation which was climaxed by the unsought and unexpected fame of the apotheosis achieved in his Letter to Gogol and his last annual reviews of Russian literature. In the end, of course, he never achieved that total purity of understanding, let alone that prophetic, messianic role sought so keenly and unwisely by Gogol himself, or the vision of a new humanity perceived by the 'sixties', or Dostoevskii's vision of a Russian Christ, or Lev Tolstoi's new religion. He achieved a reputation less as a sage than as a tribune and fighter in the cause of Russian freedom, but it was a reputation derived from and composed of the various facets of Russian literature he wanted his readers to love and respect.

This study aims to highlight what he loved and respected, for, as the subtitle suggests, it is about the struggle for love and ideas as well as the struggle for literature; and in so doing it aims to illumine the man himself. It has concentrated, therefore, on the major critical writings, the major items of correspondence and the major memoirs. It has aimed to avoid wherever possible the obfuscating mythology which has surrounded Belinskii and the idea that he should be treated in any sense as a cultural icon. He has deserved not so much re-assessment as re-portrayal, unique as he was to the literary scene. Literary critics in the west have never received the kind of adulation accorded to Vissarion Belinksii in Russia. Outside his native country his reputation has been largely confined to the background of Russian literary history. In so many ways he in fact occupied the foreground. This study aims to set him in that foreground not only as a critic but as someone who virtually worked himself to death in the service of his own literature and became in the process a reproach to absolutism in his own country and the conscience of the Russian intelligentsia and Russian literature for generations to come. 



\section{Chapter 1}

\section{The Early Years: Dmitrii Kalinin}

Born on 30 May (Old Style, i.e. on 11 June in terms of the Gregorian Calendar) 1811 in Sveaborg, Finland, into the family of a naval doctor with the Baltic Fleet, Belinskii spent his childhood in Chembar in the province of Penza where his father had been appointed to a local practice in $1816 .{ }^{1} \mathrm{He}$ was the first-born of what became a family of three sons and a daughter, but his home life was dominated by quarrels and misunderstandings between his parents. His mother, an ignorant and irascible woman, though kindly and caring, enjoyed the support of her own mother, Belinskii's grandmother, in her claims of noble origin and tended to disparage the lowlier origins of his father who came from a long line of Orthodox priestly families. The mother-in-law problem, ironically similar to Belinskii's later problem with his sister-in-law, aggravated the relationship. The father took the commonest way out by teasing his wife and drinking. Even though he quickly acquired a good private practice as the only doctor in Chembar and was reputed to be reasonably cultured, notable for his sharp Voltairean wit and gifts as a Latin scholar, his drinking soon became uncontrollable. The limited, small-town ethos of Chembar undoubtedly did much to turn him into a persistent drunkard given to violence. Herzen's recollection made the point:

'Born into the family of an official in a provincial town, Belinskii emerged without a single happy memory. His parents were cruel and uneducated as were all people of that depraved class. Belinskii was ten or eleven years old when his father, having come home on one occasion, began scolding him. The boy tried to justify himself. Flying into a rage, the father struck him and knocked him down. The boy climbed to his feet completely transformed: the hurt and injustice once and for all destroyed the relationship with his parents. He thought much how to avenge himself

1 The name appears to have derived from Belyn, a village not far from Chembar. The father always spelled his name Belynskii. 
but recognition of his own weakness developed into a hatred of any kind of family authority which remained with him to the end of his life.'2

Such testimony fitted the image of Belinskii as a champion of justice which accrued to his reputation in later years. Herzen probably heard the story at first hand. Belinskii's relationship with his parents was not in fact destroyed 'once and for all' by his father's violence; if anything, judging by his letters, it grew stronger as they grew older and greater distance came between them; but other evidence is sparse and contradictory. One legacy from the past was Belinskii's grandfather, Nikifor Trifonov. He died in 1825 at the age of 87 and was a deeply religious priest renowned for his monk-like asceticism. ${ }^{3}$ As a boy Belinskii would most certainly have known about him and probably met him. Though we have no direct testimony, it is likely that this saint-like example of the Christian life contributed to Belinskii's Christian idealism, that it informed his defiance of injustice as much as his father's Voltaireanism fuelled his own brilliant defence of Voltaire in his Letter to Gogol and that his later professed atheistic hostility to the established church was consistent with his struggle against authority as well as his respect for the individual and his own selfesteem after his father's physical abuse.

What his boyhood lacked, so far as one can judge, was any evidence of true love between his parents, let alone true love for him. By all accounts, they misunderstood him, but he understood only too well the emotional impoverishment and the hypocritical falsehood of their lives. This was the loveless world of malicious bickering, drunkenness, abuse, leading to gradual moral decline and family breakdown - all the small-mindedness, the poshlost' (in the Gogolian sense) of provincial Chembar - from which he struggled to escape. In a review of 1840 he posed the question of love between father and son, somewhat sententiously but undoubtedly out of the well-springs of a boyish anguish:

'From the moment of birth a father must dedicate his child to service of God in spirit and truth, and this dedication should not involve uprooting him from living reality but making sure that all life and every action of his in life is the expression of a living, passionate love of the truth which is God's. Only such love for children is genuine and worthy to be called love; any other is egoism and selfishness. Does a father love his son if he forces him to respect his bad and immoral acts as if they were noble and reasonable? Does it matter if one demands of a child, no matter

2 A.I. Herzen, Pss., pod red. M.K. Lemke, Vol. VI, P-grad, 1919, p. 383.

3 V.S. Nechaeva, V.G. Belinskii: nachalo zhiznennogo puti $i$ literaturnoi deiatel'nosti, 1811-1830, M., 1949, p. 31. 
what he sees, that white should be called black and black white? There is no love here, only puffed-up self-esteem which elevates its own person above truth itself. Yet a child will always have enough sense to see that when his mother slaps the maidservants on the cheek or his father gets drunk and fights with his mother something bad is happening.' (IV, 76) ${ }^{4}$

There is no doubt that something bad did happen in Belinskii's background, that he 'emerged without a single happy memory' and found his boyhood sufficiently repugnant not to mention it in detail afterwards. The nearest thing to an actual revelation of his suffering as a child occurred in a letter to Botkin (16-21 April, 1840) in which he mentioned the likely cause of his intense social shyness in later life:

'I remember what my mother said once. She was very keen on gossiping and wagging her tongue; I, an unweaned child, used to be left with a nurse, a hired girl, and to stop me disturbing her with my crying she used to smother me and hit me. Perhaps that's the reason. However, I was never breast-fed: I was born sickly and on the point of death, refused the breast and was ignorant of it (I'm doubly fond of it now), was fed by bottle and, if the milk was sour or off, I couldn't take fresh milk. Later my father couldn't stand me, swore at me, humiliated me, nagged me, hit me mercilessly and blatantly - eternal memory to him! I was a stranger in my own family...' (XI,512)

The greater the estrangement between him and Chembar, the better he understood the circumstances of his upbringing, which were by and large a reflection within a family and domestic environment of the far greater social and economic injustice of the surrounding world. He could name and easily analyse the meaning of this injustice. It was serfdom and all his life he was to crusade against it.

As a boy he witnessed its evils and consequences, if not at first hand then closely enough, and it came to be associated with an equally important, lifelong legacy of Chembar - his poor health. Again direct evidence is lacking, though the passage just quoted about the sour milk of his babyhood may suggest a cause. One may speculate, therefore, that he contracted the initial symptoms of his tuberculosis from the unhealthy diet prevailing in his home. Struggle against the ubiquitous injustice of serfdom as against illness, a struggle against personal sickness as against a sick society, was at the heart of the idealism which inspired Belinskii to seek answers in literature long before he had the philosophical or political means to justify and augment his critical approach.

4 The review was entitled 'Detskie skazki dedushki Irineia', 1840. 
Books became his guide to the world. He gained access to them less from his parents' sparse booshelves than from his schooling. If the Chembar school did little for him, the Gimnaziia, or high school, in Penza, the provincial capital, which he entered in 1825 , was where he began to demonstrate his exceptional gifts and discover for himself the appeal not so much of foreign languages or the sciences but of Russian history and literature. What he learned chiefly from the high school in Penza was a lifelong process of self-education.

Literature offered an escape from reality, both the reality of his early years and that reality which in a philosophical sense as well as in terms of lived experience was to prove so intractable and hard to reconcile. Belinskii's became a passionate, instinctive devotion to the imaginative truth of life as revealed through poetry and fiction. He never really fleshed out the bones of this boyish love. He imagined himself Alexander the Great, doted on Voltaire, sated his enthusiasm with such eighteenthcentury Russian poets and writers as Derzhavin, Sumarokov, Dmitriev, Karamzin and half-a-dozen lesser figures. Undiscriminating but always struggling to discover native talent, he did not quickly adjust to the greatness of Pushkin, though it was Pushkin's poetry, especially the early chapters of Eugene Onegin, appearing as they did for the first time during his high-school years (1825-9), which became so essential to his later view of the social purpose of literature and contributed to his own distinctive role as a literary critic.

The political events of December $1825^{5}$ were passed over largely in silence. For the remaining years of the decade and throughout the 1830s he seemed ready to accept the political status quo, at least superficially. If he did not appear to have enlightened political views in any public sense, there can be no doubt that his opposition to serfdom, the socio-economic basis of the autocracy, was privately one of great hostility. Equally certain, though, is the likelihood that it grew out of a romantic concern for freedom and was inseparable from the Byronic influences prevalent at the time, most conspicuous in Pushkin's 'southern' poems. Romanticism and protest against the status quo went hand in hand. The political intent may

5 On 14 December, the day on which guards' regiments in St Petersburg were due to swear allegiance to the new Tsar Nicholas I (after the death of Alexander I in Taganrog the previous month), officers of the leading regiments marched their troops on to the Senate Square and demanded a constitution. Known subsequently as the Decembrist revolt, the show of defiance was dispersed by cannonfire. Five of the ringleaders were hanged and at least a hundred other participants and sympathisers were sentenced to lifelong exile in Siberia. 
have been disguised, but the element of 'romance' - the love story was not. In Belinskii's case, both 'romance' and protest sprang from the same background.

His closest friends in Chembar were his cousins, the Ivanovs, and he preferred to spend time with them during the school holidays. Dmitrii Ivanov, his junior by a couple of years, has provided the fullest memoir picture of his home life and schooldays, with emphasis on the approval he received from teachers, his scholarly and literary interests, his growing self-confidence and his love of the theatre (he played Jago in a domestic production of Othello). ${ }^{6}$ His love of the theatre lasted all his life. It led him to write his only surviving major creative work, his drama Dmitrii Kalinin. ${ }^{7}$ As evidence of his state of mind, his immaturity, his romanticism and the reservoir of experience on which he could draw, this early work was evidently related to his life before he entered Moscow University in 1829 . The setting was provincial, the relationships uneasily reminiscent of Belinskii's home life and the semi-feudal conditions more characteristic of the Russian provinces than of the urbane world of Russia's second capital. If the groundwork for the play's protest was clearly laid in Chembar and Penza, its love story may also have derived from that period. There can be no doubt that the love story was as passionate as the protest.

A gloriously wordy melodrama in five acts, Dmitrii Kalinin had as its eponymous hero a young man from a servile background brought up in a wealthy serf-owning family whose father treated him as one of his own children. He fell in love with Sofia, the daughter of the family, and intended to ask for her hand in marriage, only to learn of the father's sudden death. Having returned to the family home on the occasion of a ball, he violently upheld his rights as an individual by killing one of Sofia's brothers who, notorious for his maltreatment of his serfs, had called Dmitrii 'a slave' ( $r a b)$. Imprisoned for his crime, he managed to

6 D.P Ivanov (1812?-81) was his closest friend from the Chembar period. He composed his reminiscences many years after Belinskii's death and for that reason they have to be treated with caution. See his 'Neskol'ko melochnykh dannykh...' and 'Soobshchenii pri chtenii biografii...' in Vosp. sov., pp 29-34 and 53-99.

7 Though composed in 1830-1, it was not published until 60 years later and only began to receive serious scholarly attention a century and more after it was first written largely because it fitted the orthodox Soviet view of Belinskii as a revolutionary democrat. A very full, if conventionally Soviet, interpretation of the play is given in Ch.s XVI-XVIII of V.S. Nechaeva, op. cit., and an early study which still retains much interest is to be found in S.A. Vengerov, Ocherki po istorii russkoi literatury, Spb., 1907, pp. 326-48. 
escape to see Sofia for one last time and she persuaded him to enter into a death-pact. He killed her as she had asked and then discovered that she and he had a common paternity. In a final gesture before killing himself, he tore off his prisoner's chains and proclaimed he would die as he had lived - a free man - but he was clearly not free of guilt as a fratricide and his sister's killer. Nor was he free of the sin of incest.

In Act I Dmitrii spoke of his love for Sofia to his friend Surskii. It may have begun with all the rapture of first love, he explained, yet soon it became a passion in which all feelings of purity and selflessness were engulfed by mutual physical craving. Dmitrii's description might well bring a blush to a maiden's cheek:

'It was evening. We sat in the garden in rapture as if in paradise. With trembling hands I pressed the burning hot hands of my beloved. The rest of the world vanished from sight. We had eyes only for each other and in trying to express the feelings filling our hearts we could not find the words. Our exchanges became merely broken, halting whisperings of "I love you! I love you!" and devouring looks and hot, fiery kisses. Our hearts beat like mad, our blood ran like molten streams in our veins and we were all afire with a sweet torment of desire. The remoteness of the place, the dusk of evening made darker by the overhanging trees, the rapture of our souls and forgetfulness of our own feelings drove us into each other's arms... and we blended and became dead to the world... only our suppressed groans and the strong beating of our hearts were a sign we were still alive... Ever since then for two whole months I have slaked the thirst of my passion with the nectar of love and sensuality, for two whole months I have plucked the roses of happiness with a carefree hand.' $(\mathrm{I}, 432)^{8}$

In this description he justified to his friend his prior claim that Sofia was more than a virtuous girlfriend:

'Do you think,' he asked Surskii, 'that parental consent and empty rituals are what give two human beings the right to feel love for each other and enjoy it to the full? Surely you're not in favour of such stupid prejudices that are so humiliating to human beings? It is only nature itself that unites people in bonds of love and allows them to enjoy the blessings it can give them. So, I swear to you as my friend, and to everything that lives and breathes, that Sofia is my wife!' (Ibid.)

The verbal Grand Opera rhapsodising of Dmitrii's speeches on his love for Sofia no doubt owed something to Schiller, to Shakespeare

8 Translations are from Dmitrii Kalinin in V.G Belinskii, Pss., Vol. I, M., 1953, pp. 417-503. 
(Othello, naturally) and to Byron. It conformed to acceptable tenets of Romanticism. If it came as a shock to Surskii and provoked the accusation that Dmitrii was no more than a seducer, the prior denial had taken a different form. Belinskii's own voice may be said to resound clearly through Dmitrii's rejection of rituals and prejudices, especially over sexual relationships. It had about it the kind of nihilism, the denial of all authority in such matters, that he was to express so vigorously to his future wife a dozen or so years later when he tried to persuade her to come to St Petersburg for their marriage. Much in his juvenile drama, however melodramatic and overwrought, was to foreshadow his emotional and ideological attitude of later years, particularly the plea for individual freedom and human rights. This, as much as abhorrence of serfdom and hatred of tyranny, was the play's real message.

A vacation in Chembar during the summer of 1830 reacquainted him both with relatives and with the background from which the play sprang. On returning to Moscow later than he should, to the annoyance of the authorities, an outbreak of cholera confined him to the smelly, unhealthy accommodation reserved for poor state students. ${ }^{9}$ Here, among enthusiastic friends who formed themselves into a kind of literary society, he debated literary questions and gave a reading of his play. He was renowned as 'a most zealous advocate of Romanticism' and an opponent of the rhetorical, literary conservatism (staroverstvo) of Classicism, ${ }^{10}$ but during his reading a friend remembered that 'instead of the fresh, natural pinkness of youth his face was suffused with a reddish coloration; his hair stood up on his head in a tuft; his gestures were abrupt, his movements jerky, yet on the other hand [Belinskii's] reading was heated and full of inspiration, exciting his audience with the passionate exposition of his subject and what, for that time, were liberal ideas. But despite the elegance of his explanations, the boldness of the ideas and the depth of the feelings, the play was too long-winded and had more of the lyrical about it than the dramatic.'11

As he put it in a letter to his parents of 17 February 1831, his play portrayed 'the tyranny of those who have arrogated to themselves the perilous and unjust right to torture their own kind. The hero of my drama was a man with a fiery temperament, of wild and unfettered passions; a free-thinker, his actions were mad and he perished as a consequence.'

9 Belinskii was a kazennokoshtnyi student at Moscow University, obliged to survive on the pittance of a state grant.

10 P.I. Prozorov, Vosp. sov., pp. 108-9.

11 Ibid., p. 111. 
(XI, 49-50) ${ }^{12}$ Arguably a work of high moral intent, as he was quite justified in claiming, he earnestly hoped it would be staged and so earn him the means to escape from the penury of his state grant. Encouraged by the enthusiasm with which the play had been received during its reading, he submitted it to the university censorship committee at the end of the year, but by early 1831 revolutionary events in Paris and the Polish insurrection in Warsaw had made the authorities unduly wary of likely student sedition. The play was unceremoniously branded as immoral and rejected as a dishonour to the university.

It came as a profound shock. Writing in the same letter of 17 February, he justified himself by claiming he was the most unfortunate of human beings but added with romantic self-confidence that in my breast there burns strongly the flame of those truths, high and noble, which are the destiny of the few chosen ones...' (XI, 49) To his parents, no doubt, this seemed arrogant as well as silly. Belinskii meant it. Despite complaints about lack of money and other privations (often due to his own poor management), his letters from university displayed a boldness, humour and originality which marked him out as unusually gifted. His special destiny as a chosen one (izbrannik) was not well served by the university which he had been so proud to enter. He was failed at the end of his first year and forced to repeat it. The failure was mutual in the sense that the process of self-education had left him with little respect for the sterile attitudes of his professors, while the suspicion and enmity engendered by his play had made the university authorities particularly unforgiving. When several bouts of illness compelled him to miss much of his second year, there was no forgiveness and he was expelled from Moscow University on the grounds of academic insufficiency.

12 All quotations from Belinskii's letters are taken either from Belinskii: Pis'ma (3 vols.), ed. E.A. Liatskii, Spb. 1914 or from the Soviet edition Vols XI and XII which is the fuller collection, especially for the early years, and the source to which the brackets are keyed. They are to be identified by date (Old Style. i.e. 12 days behind the Gregorian Calendar in the nineteenth century). The edition of 1914 is especially valuable because it reveals the extent of the presumed deletions in the letters and suggests more graphically the possible reasons for such censorship. 


\section{Chapter 2}

\section{From Literary Reveries to Hamlet}

The rejection of his play and expulsion from the university ended his dream of being a playwright and shattered his chances of lucrative employment. Branded with a reputation as a rebel and an atheist, he was understandably embittered, though his failure, judging from his letters, ironically brought him closer to his family. ${ }^{1}$ His university years (1829-32) had been a struggle to outgrow the heritage of Chembar and his parents in much the same way as he had struggled to escape the confining and deadening boundaries of academe. His first love was Russian literature and more of intellectual substance and stimulation about literature was to be gained from reading Moscow journals than attending the lectures of ill-informed and prejudiced professors. If his personal 'literary reverie' came to nothing, his dreams for the future of his native literature matured into his first great critical success.

The penury continued and worsened once he had left the university. He lived with the Ivanovs in their Moscow apartment for a time, surviving on translations from the French, though he was no expert linguist and his proficiency in French was never great. It was not until he had a fortuitous meeting with Nadezhdin, a professor at Moscow university and the publisher of two Moscow journals, The Telescope (Teleskop) and The Rumour (Molva), that he found himself in any kind of real employment. By 1833 Nadezhdin had apparently lost interest in editorial work. His journals had become padded out with translations. Belinskii gladly seized the opportunity to help as a translator and perform subordinate, not to say menial, tasks in helping to run the journals with the result that he very

1 His letters to his brother Konstantin of 27 January 1832, to his father of 21 May, again to his brother of 21 June and of 15 October, or his letters to both parents of February and April, 1833, as well as others for the same year, testify to his concern for his family, although when his mother died in 1835 he did not return to Chembar, nor did he return the following year when his father died. 
soon found himself assuming a nearly autonomous editorial role. Quite suddenly, at the age of 23, in 1834, the expelled student of Moscow University became famous as Russia's leading literary critic, the author of what proved to be little short of a manifesto for the future development of Russian literature, his Literary Reveries (Literaturnye mechtaniia).

Vissarion Belinskii may only have been semi-educated in a conventional sense, but he 'sat at others' feet' in the sense of being a willing member of the group of privileged young men, mostly from the nobility, who formed the so-called Stankevich circle. ${ }^{2}$ Meetings of this group introduced him to German philosophy and a great many ideas which had found no place in the archaic curricula of Moscow University, particularly the ideas of Schelling. Schelling's influence became clearly apparent in Literary Reveries, almost, one feels, in demonstration of the young critic's knowledge of what was philosophically modern or supposedly upto-date. However much he may have garnered from membership of the Stankevich circle, he nevertheless stood out in two distinct ways. He was socially a commoner and intellectually and temperamentally he was more concerned with literature than philosophy.

Among those who knew him, Herzen was particularly appreciative of this. Although referring to a Belinskii of a slightly later date, he described him as 'completely free of the influences to which we surrender when we have no way of defending ourselves from them.'3 Belinskii was devoid of scholasticism and refused to take things at their face value. We have a brilliant little cameo in Herzen's description of how, on one occasion, Belinskii rose to his feet during some heated debate over the latest ideas emanating from Berlin and declared in a voice quivering with passion:

'You want to assure me that the aim of mankind is to make the Absolute Spirit accessible to our consciousness of self, and you are satisfied with playing this role! Well, I am not silly enough to serve as the unwilling instrument of anything! If I think, if I suffer, then it's for my own sake! Your Absolute Spirit, if it exists, is not for me! There's no point in my knowing it because I have nothing in common with it!'

A typically Russian attitude, suggested Herzen, and Belinskii was above all a Russian who treated German philosophy as realistic only in a verbal sense, as essentially an earthly religion 'without a heaven', as

2 For a detailed examination of this 'circle', see E.J. Brown, Stankevich and his Moscow Circle, Stanford U.P., 1966. It is possible, incidentally, that Stankevich may have introduced Belinskii to Nadezhdin.

3 The following quotations are from Herzen's 'O razvitii revoliutsionnikh idei $v$ Rossii’, A.I. Gertsen, Sochineniia, Vol. III, M., 1956, pp. 484-6. 
Herzen put it, 'a monastery of logic where people took refuge from the world in order to lose themselves in abstractions.' When he wrote, Herzen noted of Belinskii, 'his style was often a bit awkward, but always full of energy. He used to convey his ideas with the same passion as he had taken them up. In his every word you felt that here was a man writing with his own blood, you felt how he was squandering his strength, burning himself out...' But there was never any doubting his sincerity.

The twenty-three-year-old critic's Literary Reveries had a passion laced with freshness and vigour, a fluent articulacy allied to memorable rhetoric, an eager display of knowledge coupled with a confident critical manner. No doubt could be left in readers' minds that here was a master. It was a mastery evident in the range of literary awareness directed to the task of answering the question 'Does Russia have a literature?'; and if it does, what role should be ascribed to it in the national life?

The style initially mixed the conversational, bordering on a parody of itself, with the magisterial and hortatory in a tone of mildly absurd professorial levity. What is literature? The answer was threefold: it was the entire intellectual activity of a nation expressed in written form (so some authorities maintained); or it was a collection of the chef d'oeuvres de littérature; or, more elaborately, it was a collection of those artistically literary works which gave expression to the spirt of the people ( $d u k h$ naroda) to which the writers belonged. In this sense a literature should be regarded as 'organic', loosely speaking, meaning that it constituted a natural, seamless evolution unaffected by outside influences. In other words, such a literature cannot be simultaneously French, German, English, etc. At which point Schellingian ideas leave their mark on this 'Elegy in Prose' as Belinskii subtitled it.

Literature may be a reflection of society, meaning, in the French derivation of the expression, that it may reflect high society or the beau monde, but this definition, which was always of the utmost importance for the critic when it referred to the whole of society, required to be made more precise. Here he insisted that literature had to be the expression or the 'symbol', as he put it, of the inner life of the nation, because (the Schellingian vision here emerges) 'the whole limitless, beautiful, divine world is nothing other than the breathing of a single, eternal idea (the thought of a single, everlasting God) manifest in countless forms as a magnificent spectacle of absolute unity in endless variations.' (I, 30)

In the light of this revelation man should recognise with pride and humility that he was the creation of a divine idea living within each individual, that life itself was action and action involved struggle and that the utmost, everlasting bliss was to be obtained from the obliteration of one's 
ego in a feeling of love. The moral life of the eternal idea involved a struggle between good and evil, love and egoism, without which there was no merit in living, just as without merit there was no reward, and without action there was no life. Art therefore became the expression of the great idea of the universe in its endlessly varied manifestations. The poet was given the unique role of allowing the reader to survey in miniature the whole of nature, so that he may perceive the very breathing of the life that inspired the universe and the reader may feel in his very soul the fire within it. 'The pleasure of art must involve a momentary forgetting of our ego in a living empathy with the universal life of nature; and a poet always achieves this beautiful aim if his work is the fruit of highmindedness and passionate feeling, if it has flowed freely and uncaringly out of his soul...' (I, 34)

Romantic this may be, yet for all the ideological or political changes he underwent in the course of his career as a literary critic Belinskii retained by and large throughout his life this exalted view of the poet as one essentially passionate in pursuit of his craft and sullen art. The main purpose of the Reveries, though, was more specific and related directly to the fact that, in Russian circumstances, society and people were irreparably divided. If, in the course of Russian history, the mass of the people, meaning the peasantry (narod), remained culturally backward, high society (obshchestvo) civilised itself in the sense that it attempted to Europeanise or Frenchify itself. Ironically the first figure of any real importance in Russian literature, the 'Peter the Great of our literature,' as Belinskii called him, Lomonosov, was self-made and of humble origins. Still, he was not as gifted, poetically speaking, as Derzhavin, the fullest expression of the era of Catherine the Great; and Karamzin, if unfairly branded here as a children's writer, at least received the accolade of recognition as a good historian. None, however, earned as many plaudits as did Pushkin and his, the so-called 'Pushkin period', was the richest in literary terms of any that Russian literature had so far experienced.

As the leading Soviet biographer of Belinskii put it: 'Pushkin was for the author of Literary Reveries the conspicuous mountain peak which could serve as a measure of all other literary achievements. ${ }^{4}$ Pushkin

4 V.S. Nechaeva, V.G. Beklinskii: uchenie v universitete i rabota v 'Teleskope' $i$ 'Molve' 1829-1836, Izd. Akad. nauk, 1954, p. 287. The analysis of Literary Reveries which Nechaeva offered was exceptionally broad-minded and objective by the standards of the Stalinist period. The analysis offered in Herbert E. Bowman's Vissarion Belinskii 1811-1848: A Study in the Origin of Social Criticism in Russia, Harvard U.P., 1954, was the first extended one in English (pp. 54-70), although it polemicised with its subject and stressed the 'disorder' of the Reveries. 
did serve as such a measure, and for personal reasons. He may have been 'a son of his time in the full sense of the word,' so the critic expressed it, 'a complete expression of his time,' but he was much more than this. He was a magician. The effect of his magic in national terms was felt by all who fell under his spell. This was true of the remotest parts of Russia, even of despised Chembar in the very depths of Penza province, where Vissarion Belinskii had his earliest experience of the poet:

'Like a magician, he at one and the same time elicited from us both laughter and tears and played at will with our feelings... He sang, and the whole of Russia was astonished by the sounds of his songs. And no wonder - she had never heard anything like them! How hungrily she listened to them, and no wonder - every nerve in her life quivered at their sound! I remember that time, the happy time when, in the depths of the provinces, in the peace and quiet of a small country town, on summer days there floated through open windows sounds resembling the breaking of waves or the soft murmurings of a stream...' (I, 72)

No other poet or writer mentioned in this precociously bold survey of Russian literature earned the personal praise reserved for Pushkin. Other talents were given the fullest recognition - Zhukovskii, for example, Krylov and Griboedov - and Belinskii was to conclude by answering his own question about Russian literature by denying that such a literature existed in the true meaning of the word but it had four principal 'representatives': Derzhavin, Pushkin, Krylov and Griboedov. In fact, such pedagogic pats on the head mattered a lot less in the context of the critical approach than did the attempt to offer a philosophical framework for the appraisal of Russian literature and the attempt to define its evolving character. If the philosophical framework, in the shape of a rather awkwardly inserted Schellingianism, had little real meaning and was seriously at odds with the critic's main function of surveying and evaluating Russian literature in historical and social terms, the attempt to define its evolution was bold and far-sighted. The criteria may have been broad and rather sketchy, but by introducing and endeavouring to define what, in Belinskii's terms, was meant by narodnost', or 'popular', truly 'national', feeling, he was performing a vital service. He was defining, in short, what Russian literature was to be: not the literature of official Russia, of official nationalism, with its threefold pillars of autocracy, orthodoxy and narodnost' (as 'nationalism' in a jingoistic, xenophobic sense), but a literature which was national in its truthful depiction of Russian life. Such 'true-to-life' literature had only begun to appear with Pushkin, in what Belinskii dubbed the 'Pushkin period' of Russian literature, meaning in a 
loose sense the $1820 \mathrm{~s}$. But what Russia needed, he concluded, was not so much a literature as 'enlightenment' (prosveshchenie). A literature would appear regardless, but what Russia needed was civilisation in a Western sense, just as its literature should ultimately be judged in terms of its European counterparts.

In the final estimate, there was nothing very systematic about Belinskii's exposition of his views and nothing very specific about his conclusions apart from his insistence on respect for the individual, freedom of speech and access to new ideas. In the autocratic Russian empire of the 1830 s, with its millions of enserfed, illiterate peasantry and possibly no more than fifty thousand semi-educated noble serf-owners, Belinskii's voice did not sound loud. It was little more than a whisper of common sense in an asylum for the insane. But it spoke of the need for Russia to look westwards for the source of enlightenment and civilisation. It also spoke loudly of Belinskii's erudition, practically wholly selftaught, and his love of literature.

Most of all, it spoke of the need to ask questions. There is no evidence to suggest that at this stage in his career he had any clearcut political aims. What he had was a desire to ask questions and his critical articles were full of them. Mostly of a pedagogic kind, to which the answer was always ready to hand, but no reader could fail to be aware of the dialectical nature of the exercise or the informative, educative and mind-broadening intent of the critical treatment. Add to this format the subjective pathology of the questioner and in embryo you have the characteristic question-andanswer manner of Dostoevskii's Devushkin and Underground Man. The mannerism, if hardly deriving from Belinskii, became so inseparably his that much of the dialogism of later Russian fiction and publicism evolved from it. ${ }^{5}$ To this extent his work as a critic was fundamental in encouraging and nourishing the growth of a question-asking intelligentsia. It was also fundamental, as his work for Nadezhdin's journals in 1835-6 was to

5 Lydia Ginzburg has taken the notion a step further in her valuable examination of the relationship between Belinskii's prose and his ideas by pointing not so much to the dialogism as to the psychological implication of this method when she writes: '...it should be remembered that this habit of detailed and, at the same time, generalized examination of psychic life laid the groundwork for the psychological novel, since the characteristic feature of the Russian sociopsychological novel is, after all, that in it ideology permeates the material of ordinary social life, and that the facts of private life are raised to the level of philosophical generalization.' On Psychological Prose, Princeton U.P., 1991, pp. 64-5. 
show, in making readers aware of the European models against which Russian literature should be judged. ${ }^{6}$

His first extended critical examination of prose writing in Russian literature - 'About the Russian Short Story and the Short Stories of Mr Gogol (Arabesques and Mirgorod)' (O russkoi povesti i povestiakh g. Gogolia: Arabeski i Mirgorod) - became the first work of his to appear above his full name. In the absence of Nadezhdin, who had gone abroad, Belinskii had temporary charge of The Telescope in which the article was published in 1835. It was the most important item it published that year, to be rivalled in significance in the following year only by the publication of Piotr Chaadaev's influential and subsequently notorious first 'Philosophical Letter' (Lettre philosophique). ${ }^{7}$

'Our entire literature,' Belinskii declared, 'has been turned into the novel and short story.' (I, 261) The influence of European literatures was principally responsible for this, and the question naturally arose whether there could be such a phenomenon as an indigenous Russian novel. $\mathrm{He}$ began his answer with a discussion of theory and a historical review and suggested theoretically, in a very broad sense, that there were two kinds of poetry or literature - the 'ideal' and the 'real'. The latter clearly interested him more because it admitted the existence of 'the individual with his free will, his passions, his desires and deprivations,' (I, 263) something which was not to be found in Greek literature and only became apparent with the arrival of Christianity. Although the short story was a recent phenomenon in Russian literature, Gogol could be regarded as having achieved lasting fame due principally to "the simplicity of his ideas, his national spirit (narodnost'), complete truth to life, originality

6 For an enumeration of the writers and their works which Belinskii helped to promote while working for Nadezhdin's journals, see Nechaeva, op. cit. The list includes Victor Hugo, Bulwer Lytton, Alfred de Vigny, Balzac, Heine, Goethe, Molière, Walter Scott, Shakespeare, Schiller and Byron.

7 Chaadaev's first 'Philosophical Letter' (1836) came to be regarded as a treasonable attack on the doctrine of 'official nationalism' because it offered a bitter indictment of Russia's lack of indigenous culture and attributed the cause of such backwardness to the fact that Russia had received Christianity from the 'corrupt source' of Byzantium. Chaadaev held strongly pro-Catholic views but was in no sense politically dissident. Declared mad by the authorities, he was subjected to compulsory medical inspections, but he was not exiled, as was Nadezhdin, who had authorised the publication of his 'Letter' (the first of eight) in The Telescope, which was subsequently banned. 
and comic inspiration which is always overlaid by a deep sense of sadness and despair.' (I, 284) Such qualities made Gogol 'the poet of real life.' This said - and however much later criticism may have altered and enriched our understanding of this writer's complex personality - Belinskii immediately set about trying to define what he meant by making such a claim.

Creativity, the act of being inspired to write, had priority over subjectmatter, but it was an act involving a great mystery. The moment of creation was akin to the performance of a religious rite. It drew into it, as an act, an idea which possessed the writer's soul, with the result that 'the chief defining characteristic of creativity is a kind of mysterious clairvoyance, a poetic somnambulism,' (I, 286) words which came close to parodying the Romantic notion of the poet/writer as one inspired by an opiate. But the essential message of Belinskii's concern with priorities was to insist that the poet/writer was, if his talent and genius were truly great, subservient to his subject, 'because he had no say in its choosing, nor in its development, because he cannot create to order or on command, nor by his own will if he is not inspired, which certainly does not depend on him: consequently, what is created is free and independent of the person creating it, who here is as much a sufferer as he is a doer.' (I, 288)

About Gogol himself as a writer the critic may have seemed too simplistic, even naive and onesided in his judgement. The emphasis on the writer's 'simplicity' allied to his 'humour', his supposed 'impartiality' and 'truth-to-life', his 'originality' and his 'comic inspiration' was perfectly justifiable in the light of the St Petersburg stories and the works in Mirgorod. Throughout his review Belinskii was quite ready to treat Gogol as justifiably the equal of European writers, in particular of Shakespeare in certain instances, but his uniqueness resided in his humour. It had a twofold edge, distinguished, on the one hand, by the calmness of its indignation and the warmth of its cunning, and on the other by the way it could 'draw blood with its bite, bite down to the bone, strike straight from the shoulder, whip right and left with its knout made of hissing snakes a humour bilious, poisonous and merciless.' (I, 299) These were strong and forceful claims for the power of Gogol's satire. That Belinskii was also aware of a darker and more complex side to Gogol can be discerned from his tirade about the writer's ability to depict two types of human nonentity (nichtozhestvo) or what may be called poshlost':

'There is a base, crude nonentity, naked, unadorned, filthy, stinking and in rags; and there is also an arrogant kind of nonentity, self-regarding, opulent, magnificent, giving rise to doubts about the true nature of things in the purest and most ardent of souls, a nonentity who travels in a 
carriage adorned with gold, who talks intelligently and bows so politely you are overwhelmed by him and prepared to think he is really one of the great and knows the purpose of life and you are kidding yourself, you are just chasing after a will o' the wisp. For each kind of nonentity a special kind of scourge is needed, and a strong one, because both kinds have hides of brass. Each kind of nonentity needs its own Nemesis, because it's essential that people should sometimes wake up from their senseless dormant state and recall their nobility as human beings; because it's essential that they hear a thunderclap from above and be reminded of their creator; it's essential that... the desolate and triumphant tolling of a church bell should suddenly interrupt their mindless pleasure and remind them of God's sanctum which all must approach with repentance in their heart and a hymn on their lips!...' (I, 300-1)

The Gogol who could wield his satirical knout to this effect and for this purpose was the Gogol who, in Belinskii's final estimate, now stood at the head of Russian literature and would take the place previously occupied by Pushkin, but it is not hard to discern in this analysis the suggestion that the ultimate criteria were religious and likely to prove less abrasive and more conservative than the satire might have led one to believe.

Before Pushkin's tragic death in a duel in January 1837, he had known of Belinskii and even contemplated the possibility of inviting him to contribute to his own journal The Contemporary. He thought of him as showing talent and promise. 'If along with the independence of his opinions and his wit he combined more scholarship, more evidence of reading and more respect for tradition, more circumspection - in short, more maturity - we would have in him a very remarkable critic. ${ }^{8}$ Gogol was also to approve of Belinskii's estimate of his work, particularly what he regarded as the 'compassion' shown by Gogol for the sadness of Russian life. This was to form a large part of what Belinskii was later to call the 'subjectivity' of Gogol. It never exactly measured up to the critic's hopes for the author's satire as a scourge of the nonentities in Russian life, though it was precisely this image of the knout or scourge that the critic was to use against him in his Letter to Gogol of 1847.

In 1836 his career as a literary critic seemed on the point of ending. The Telescope was closed on government orders for the publication of

8 Nechaeva, op. cit., p. 415. 
Chaadaev's 'Philosophical Letter' and Nadezhdin was exiled. But literature yielded to life more passionately than ever. Though Belinskii found himself implicated in the closure of the journal and had his rooms searched for dissident material, he was implicated, in emotional terms, in other matters. In the second half of August of that year he went to the Bakunin estate of Priamukhino and spent almost three months there in the company of Mikhail Bakunin (whom he knew familiarly as Michel) and his sisters. It was here, not for the first time in his life, and not perhaps for the last, but certainly in a crucial sense, that he confronted his own 'nonentity' and undertook to alter it with Michel Bakunin's help. The change did not occur immediately, it seems. Only when a year had passed was he able to assess, in deeply emotive terms, the effect of his Priamukhino holiday, judging at least from the fact that he did not express it in writing until his letter of 16 August 1837 when he wrote at great length to Michel describing it as a moment of 'harmony':

'The Priamukhino harmony did not directly assist my awakening but was its chief cause. I felt myself in a new sphere, saw myself in a new world; all around everything breathed harmony and bliss, and this harmony and bliss penetrated in part into my very soul.' (XI, 173)

In fact, the long sojourn at Priamukhino (near Tver) was not quite as harmonious as this makes it sound. Being in the company of Bakunin's sisters may have been cause for great delight and the beginnings of a platonic love for at least two of them, Aleksandra and Tatiana, but some unduly radical words of his about the French Revolution alienated their conservative father. His relations with Michel combined love and hate. The lengthy correspondence between the two of them in 1837 and later had evident candour (judging from Belinskii's letters; Bakunin's have not survived) and could tempt one to imagine that it was romantically as much homophile as philosophical. A degree of infatuation must certainly have existed between them at first. In the light, though, of Bakunin's emotional volatility and jealousy, his attachment to Belinskii may have turned sour as a result of the latter's interest in his sisters. In any event, Belinskii left Priamukhino in a hurry to return to his Moscow apartment. He had apparently been forewarned of the likelihood of a police search in the wake of the closure of Nadezhdin's journal and this may have been the reason for the destruction of private correspondence, since practically nothing remains of his correspondence for 1836 .

By the summer of 1837 he was at Piatigorsk in the Caucasus taking the waters and bathing to alleviate his consumption. It was a trip paid for by his friend Botkin and others and he hoped to repay such generosity through the publication of a work he had been preparing since 1834 , his 
The Foundations of Russian Grammar for Primary Instruction, compiled by Vissarion Belinskii. Published in the summer of 1837 while he was in the Caucasus, it in fact sold slowly and enjoyed no financial success. ${ }^{9}$ The real success of this period of recuperation in the Caucasus related not so much to his physical health, improved though it was, as to the health of his own personality, due to contemplation of the ideas about the ego which he had discussed with Michel Bakunin the previous autumn at Priamukhino. It led him to contemplate a project dear to his heart and deeply expressive of his own personality - a book containing an exchange of letters. It would be a logical extension of the sort of dialectic which formed the dynamic of his critical articles. Nothing came of this plan, strictly speaking. Posterity can only glimpse it through the correspondence of intense personal honesty and depth of feeling which he conducted with Michel over the next couple of years.

The world of Piatigorsk, its social complexion, its loves, enmities and feuds, must exist for us principally as it is mirrored in Lermontov's famous novel $A$ Hero of Our Time (1841), particularly the longest section 'Princess Mary'. The hero Pechorin would no doubt have had as little time for Vissarion Belinskii as he had for the honourable and puzzled Shtabs-Kapitan Maksim Maksimych. Lermontov himself had equally little time for him when they did meet and disagreed, it seemed, over Voltaire. ${ }^{10}$ On this occasion Lermontov was far too frivolous for Belinskii's tastes and they parted with mockery on the one hand and cold disdain on the other. Whether or not they had known each other when they were coevals at Moscow University in the late 1820s and early 1830 s, or perhaps even eariier, must be in doubt.

But for Belinskii the cultivation of his own personality had priority in both a private and a public sense. The private aspect can be seen at its most explicit in a long confessional, condescending, hortatory epistle to his relative D.P. Ivanov of 7 August 1837. Hectic and passionate, oscillating crazily between the sublime and the ridiculous, the letter revealed its author as engaged in a turbulent process of self-examination.

9 A detailed description of Belinskii's Grammar may be found in Ch. II of V.S. Nechaeva's V.G. Belinskii: zhizn' i tvorchestvo 1836-1841, Izd. Akad. nauk, 1961.

10 It is described by N.M. Satin, a mutual friend, in his Reminiscences. See Vosp. sov., pp. 136-8. Lermontov had spent some of his childhood on his grandmother's estate not far from Chembar. It is tantalising to think that Lermontov might have heard of his slightly older contemporary either at that time or later at Moscow University, since there is a character in his early drama The Strange Man (Strannyi chelovek,1831) with the name of Belinskoi. 
He had, for example, certain standards, he declared. Snobbish ones, it can be said, which would prevent him from inviting a shoemaker to dine with him not because he was of low social standing but because he was 'a swine, a beast in the crudeness of his ideas, habits and behaviour,' (XI, 142) because no matter how kind-hearted, honest and intelligent he was he had no 'aesthetic feeling'; and without that a man would inevitably remain a beast. Similarly, scholarship, as epitomised by the professors at Moscow University, was mediocre and rubbishy. In short, people should adopt new standards, even new religious standards in a New Testament sense. In a highly revealing passage he insisted:

'...there is no friendship between people and cannot be, but there is the brotherhood which Christ preached, there is a kinship between them based on love, and a striving towards God, and God is love and truth, God is not something separate from the world, but God is in the world because he is everywhere. Yes, as the great apostle John, Christ's beloved disciple, has said, no one has seen him; but he is present in every noble impulse of man, in his every enlightened thought, in every sacred movement of his heart. The world or the universe is his temple, and the heart and soul of man or - better - the inner "I" of man is his altar, throne and holy of holies.' (XI, 145)

For all the presumed agnosticism or atheism attributed to him, this passage has a ring of conviction about it which should not be overlooked in any ultimate assessment of Belinskii's ideas. As for the inner ' $\mathrm{I}$ ', the ego, it comprised thought clothed in a body, where priority should be given to the idea rather than the phenomenon. Yet, even though philosophy should be the true focus of one's activity, art must be the startingpoint; and art must be treated worshipfully as a means of achieving a higher enjoyment accessible only to the spirit. Love must be the key, a love stronger than Sampson's prodigious strength, for love may lead to perfection. Education, on the other hand, was the path to true happiness.

When it came to politics, Belinskii's views had a bizarre idealism made deliberately obscure, perhaps, in view of likely perlustration. He acknowledged the enormous contribution of Peter the Great in transforming Russian backwardness, but he had also to admit that Russia was still in a state of childhood and freedom for the people could only mean licence (ozornichestvo). True freedom would only come from 'enlightenment'.

The extent to which Belinskii was reconciled with reality and therefore became an apologist for the political status quo was highlighted by this letter of 1837 . He was obviously no 'progressive' long before he became closely acquainted with Hegel. 'Autocratic power,' he insisted in this 
letter, 'gives us complete freedom to think and form ideas, but limits our freedom to talk loudly and interfere in its affairs.' (XI, 150) He went on to give his warm approval to the policies of the autocratic government and the need to preserve Russia from 'damaging' political influences. Politics was a heady wine which in Russia could even turn into opium. As for himself and those like him, the Russian intelligentsia in embryo, they were to be 'apostles' of enlightenment. 'So we will copy the example of Christ's apostles who did not make conspiracies and did not found either secret or open political groups but who never denied Him in front of kings and judges and never feared either fire or sword.' (XI, 151) It was an unsullied vision of the intelligentsia's purpose and role, a denial of politics in the name of knowledge that was simultaneously a repudiation of French thought and the French concern with history in favour of German philosophy as a development and explanation of Christian teaching. Its true value lay in the importance Belinskii ascribed to individual man. Man is free, duty does not exist for him, he concluded, on the supposition that man should be virtuous out of love, not out of duty. By the same token, therefore, it was not Peter the Great that transformed Russia, but Providence, just as a poet is born a poet and will die a poet. Forget usefulness, he insisted, and remember love. 'It is not love of one's country that must make us do good, but love of goodness, not usefulness deriving from good, but goodness itself.' (XI, 154)

As an exercise in self-examination designed to instruct himself, one assumes, as well as his addressee, the letter was no real manual of future conduct. Its sublimities scarcely outweighed its manifest absurdities. It should be considered the private accompaniment of the public exploration of personality which Belinskii offered in his study of Shakespeare's Hamlet published the following year. ${ }^{11}$

The study, amounting to about 100 pages in length, was composed mostly during his stay in Piatigorsk and inspired both by recollections of seeing the famous actor Mochalov ${ }^{12}$ playing the role on the Moscow stage in the early months of 1837 and by renewed visits to the theatre to see him after his return to Moscow that autumn. He published it in The Moscow Observer of which he became editor at the beginning of 1838 .

11 It was published as 'Hamlet, Shakespeare's drama. Mochalov in the role of Hamlet' in The Moscow Observer in the March, April and June Nos, 1838, signed 'Vissarion Belinskii'.

12 P. Mochalov (1780-1848), of serf origin, was the leading actor of his age and the first to create Hamlet on the Russian stage in the prose translation of N.A. Polevoi (1796-1846). Mochalov's acting was erratic but noted for its emotional expressiveness and its power at moments of inspiration. 
Hamlet was a new experience for Russian audiences and this extended critical article was the first major attempt in Russian to deal with it both as a play, as a study in a particular type of hero related to other dramatis personae within the play, and as a performance, as the interpretation of the role by a Russian actor of undoubted talent verging at times on genius. It was therefore as a study more a scene by scene exposition of the play for a readership unacquainted with the work than a disquisition on the character of the Prince of Denmark. But its assumptions were noteworthy.

It assumed, for instance, what for Belinskii in much of his later criticism was to be axiomatic, that great art had a human immediacy and universality. 'Hamlet!' he exclaimed. 'Do you realise what the word means? It is great and profound: it is all human life, it is man, you and I, it is each of us, more or less, in an exalted or comic, but always in a sad and pitiful sense...' (II, 254). Consequently, Belinskii emphasised the human relevance of Shakespeare's play and its hero and the further assumption that, as a replica of life, it was organically self-contained: 'Hamlet is an entire separate world of real life, and look how simple, ordinary and natural this world is despite all its extraordinariness and high nobility.' (II, 290) As for Hamlet himself, the interpretation put upon him in part reflected Belinskii's own profound process of self-discovery as well as the desire, however obliquely expressed, to see in him a model for the type of enlightened individual who could be a future 'apostle' of the intelligentsia. For Hamlet had to have faith, a belief in himself and his purpose, and he had found that faith challenged by the death of his father, his uncle's machinations and his mother's betrayal. 'Love was his second life' (II, 291) we are told and his love had been betrayed. This must account for the bitterness he displayed towards his erstwhile love, Ophelia.

Hamlet, in short, was an idealist shaken to the roots of his being by the reality of his world. 'And the higher is a man in spiritual terms, the more terrible is his fall, and the more triumphant his victory over his ultimate state, the deeper and more sacred his blessedness. That is the meaning of Hamlet's weakness. Ask yourself in fact: What brought him to such terrible disharmony and condemned him to such a painful struggle with himself? The incompatibility of reality with his ideal of life - that's what did it...' (II, 293) So the conclusion offered was:

'The idea of Hamlet is: weakness of will as a consequence of breakdown, not by nature. By nature Hamlet is a strong man... He is great and strong in his weakness because a man who is strong in spirit is greater even in his fall than a weak man in his highest state. This idea is as simple as it is profound; and it is what we have striven to demonstrate.' (Ibid.) 
Vissarion Belinskii aimed to become 'strong in spirit' for there was no denying that, even though improved, his physical health remained weak despite the months spent in Piatigorsk. He looked to Michel Bakunin as the guru who would help him in his search for an ideal, a philosophical means, that is to say, of achieving an ideological reconciliation with the real. The political implication of such a search may not have been immediately apparent, no more than the idea of an intelligentsia as 'apostles' had any reality at that time. The gospel for such 'apostles' was as yet neither fully prepared nor properly uttered, but buried in Belinskii's study of Hamlet was the model for the future. 



\section{Chapter 3}

\section{From Hamlet to Reconciling the Real}

Hamlet's dilemma as Belinskii defined it - the incompatibility of reality with his ideal of life - clearly reflected his own problem. He sought to develop his own personality through trying to discover an ideological truth that would both satisfy his inherent idealism and reconcile him with reality. One such means seemed to be offered by Hegel. In one of his customary long letters written over several days (29 September-8 October 1839), this time to his friend N.V. Stankevich ${ }^{1}$ shortly before the latter's early death, he referred to what happened after his return from the Caucasus:

'I arrived in Moscow from the Caucasus, Bakunin arrived, and we lived together. During the summer he had looked at Hegel's philosophy of religion and right. A new world opened before us: might is right, right is might. No, I can't describe to you what I felt when I heard those words - it was a liberation! I understood instantly the fall of kingdoms, the legality enjoyed by conquerors. I understood that there is no such thing as an untamed material force, no power wielded by the sword and bayonet, nothing arbitrary, nothing accidental — and my burdensome guardianship

1 N.V. Stankevich (1813-40), the founder of the 'Stankevich circle', not only introduced Belinskii to the ideas of Schelling but also became interested in Hegel under the tutelage of Karl Werder while in Berlin in 1837. His influence on his contemporaries was due as much to his endearing personality as to his learning. The comparison which Turgenev made between Pokorskii and Rudin in his first novel Rudin (1856) offers the best summary of the difference between Stankevich (Pokorskii) and Bakunin (Rudin) as early and formative influences on the ideological development of the Russian intelligentsia. Marshall Shatz has, however, challenged the idea that Rudin was based directly on Bakunin; the portrayal may have been coloured by Belinskii's attitude to Bakunin. See Marshall Shatz, 'Bakunin, Turgenev and Rudin,' The Golden Age of Russian Literature and Thought, ed. Derek Offord, Macmillan, London, 1992, pp. 103-14. 
of the human race was at an end, the significance of my fatherland appeared in a new light...' (XI, 386-7)

The need for a faith remained an essential adjunct in the personalitybuilding process and there is no doubt that Hegelian thought acted upon Belinskii as a catalyst much as it did for Bakunin himself, for Herzen and Turgenev. In Hegel he was to find something more relevant to his needs than the ego-centred universes revealed by Schelling and Fichte because external reality for Hegel was implicit in the self even though related to it by a dialectical idealism. The slogan 'What is rational is real and what is real is rational' may have achieved an importance virtually synonymous with 'Might is right, right is might' and led to conclusions of extreme conservatism in interpreting the state of the body politic in Russia (although, of course, it had an exactly opposite effect on Herzen), but the correspondence with Michel Bakunin reveals conclusively how deeply personal were the impact and influence of Hegel's thought almost wholly perceived as it was through the prism of Bakunin's personality since Belinskii himself knew no German. ${ }^{2}$

There is no doubting that what drew Belinskii and Bakunin together was not the deference of the former for the latter, though Belinskii clearly admired his friend, but his love for Bakunin's sisters, particularly Aleksandra and Tatiana, or - rather - for the idea of love itself as perhaps idealised in these women who were (so he claimed in his letter of 16 August 1837 from Piatigorsk) 'a thousand times better than you, a thousand times more perfect than you.' (XI, 161) In this, the first of his longer, confessional letters to Michel, he was already berating his friend for not taking account of the fact that 'Love does not despise the fallen but sheds tears over them...' (Ibid.) and that he himself divided human beings into two classes, those who have the germ of love in them and those who don't.

To all intents and purposes Michel lacked the germ, certainly in the sense that Belinskii meant it, whereas he himself was only too conscious of being a fallen one: 'A man, liberated from the fetters of his own nothingness and aware of the Kingdom of God within him, weeps with joy and begs his fellow men, as if he were offering them alms, to share with him in his blessedness.' (XI, 162) Michel by contrast was a triumphalist consumed by his own need for victory and much less honest than his correspondent. The honesty with which Belinskii subjected his own

2 Bakunin's ideas and the sources from which he derived them are excellently described in Chapter I of Aileen Kelly's Mikhail Bakunin: A Study in the Psychology and Politics of Utopianism, Clarendon Press, Oxford, 1982. 
personality to scrutiny and 'confessed himself' must be considered one of his most appealing traits. He recognised that he had two principal defects: self-esteem (samoliubie) and sentimentality (chustvennost'). The latter defect, deriving from an excessive emotionalism, naturally drew him to women, and he went on to write a little later:

'How can it be that a man who understands as well as I do the place of women in our lives, who feels for every worthy woman such a sacred, such a deferential sense of worship, whose soul thirsts for a pure and noble love and has maybe more than once quivered and swooned in anticipation of this blessing, can it be that such a man has not the strength to overcome his base emotional urges and be repelled by them?' (XI, 169)

It was a question partly resolved, he claimed, by his stay in the Caucasus, but prompted very largely by his Priamukhino experience of the previous year. This involved the influence of Fichte, though the extent to which he really assimilated Fichtean ideas must remain in some doubt:

'The life of ideas and the life of reality have always been twofold in my understanding of them. The Priamukhino harmony and my acquaintanceship with the ideas of Fichte, thanks to you, convinced me for the first time that ideal life is precisely real life, positive, concrete, while socalled real life is negation, fantasy, nothingness, emptiness. And I learned of the existence of this concrete life in order to realise my inability to assimilate it; I learned of paradise in order to assure myself that only arrival outside its gates, not the pleasure of it, only the anticipation of its harmony and its fragrances was the naturally possible life for me.' (XI, 175)

In terms of personal relationships, however, rather than ideas, Michel's influence on his supposed acolyte was unpleasant in many ways and Belinskii would live to regret it. Significantly, as this letter of August 1837 was to disclose, what he really discovered in the Caucasus was a renewal of his respect for Pushkin, a revival, that is to say, of his love of Russian literature, and fondness, above all, for his friend Botkin who, apart from Michel's sisters, was the 'first saintly person I have ever known.' (XI, 179) ${ }^{3}$

For all that the move from Fichte to Hegel was a 'liberation', the only truly liberating experience in Vissarion Belinskii's life was an emotional commitment to literature and particular people. A recurrent theme in his letters, especially the lengthier, more candid, confessions written to friends before he married, was the need for love. Often it had a faintly

3 This is a curiously ironic claim, for Botkin was to become notorious for his immorality when he later went abroad. 
self-pitying sentimentality, even a sickly 'spirituality' about it, as in his letter to Michel Bakunin of 1 November 1837 when he wrote that 'love weeps and grieves over the vices and errors of those nearest and dearest but does not hate, because life in its goodness does not have any place for endlessly thinking about evil and hatred for it and, what is more... there is no evil in the universal life of the spirit, but all is goodness.' (XI, 186-7)

He depended, he claimed, and his letters abundantly bear it out, on the friendship of those closest to him. But his love at this time found its fullest expression in the realisation that in Pushkin 'there was an unquenchable well-spring of love which could not dry up for whatever reason, and from the cradle to the grave love smiled on him. That is the only kind of life I understand, and if I sometimes live such a life (as a sun seen in a river is only a reflection of the sun itself), then it is not in reality but only in my fantasies.' (XI, 191)

Throughout November 1837 he wrote page after page to his friend Michel. It was obviously a therapeutic exercise involving the most personal of confidences and the resulting confusion between philosophical issues and thoughts on love and literature must be excusable. But there may have been something else. A letter of 15-20 November can provide grounds for believing that the degree of confessional candour in their correspondence had deeper significance than appearances may suggest. Referring to Michel's jealousy over Belinskii's feelings for the Bakunin sisters, he praised Michel's candour in confessing as much. The text then reads:

'...complete candour is the first condition of friendship, and I give you proof of it by saying I not only love you more, but I also respect you more now. I placed you on stilts in my opinion of you, I respected you as an ideal, but my respect was cold; now you have come off your stilts, you have shown yourself in a pitiful, humiliated, even a despised light, but now I respect you warmly and enthusiastically, you are shrouded in my eyes in a kind of fantastic greatness. Yes, my poor and noble Michel, the person who can make such a confession, he is a real man. I regret you didn't do it before: perhaps at that time you'd wanted to curtail your hurt; but perhaps is always merely a supposition and often amounts to perhaps not. The spirit grows in time and through circumstances: the circumstances are essential. You fell horribly, but because you had to fall, because it was only by this means you could reach your present state of development. Your falls are now for you a phantom, but all that matters is that you've got to your feet and you've got to your feet - now I agree about this - so as not to fall again...' (XI, 206)

The obliqueness of the references can make it seem that these 'falls' were ideological, but the fact that at least ten lines of the letter have 
apparently been deleted at this point ${ }^{4}$ and the text then continues with reference to a second 'circumstance' which apparently shocked Belinskii must invite speculation about the emotional content of the missing lines. Belinskii went on to mention the way Michel had behaved badly towards him during the Priamukhino visit:

'Oh, you stuck a knife into my heart and turned it as if you enjoyed torturing me! This is not just phrase-mongering on my part - I can prove it to you: before your last letter (which changed my attitude to you and laid the foundation for my true friendship for you) I loved and hated you. I loved you sincerely, loved you for yourself, loved you because I owed my development as much to you as to Stankevich, loved you because I love all your sisters with the sort of love that ennobles me and serves as a guarantee for me of everything beautiful in life, finally I love you because one of them has more significance for me than the others; ${ }^{5}$ and yet at times I hated you. I used to take a devilish delight in denouncing you and discussing your boyishness.'

What was this boyishness (mal'chishestvo)? Was it Michel's jealousy of Stankevich over the latter's relationship with his sister Liubov'? The boyishness seems to have been a sin of a different kind because, towards the end of the letter, there is a further deletion of even greater significance and length. The text runs:

'Your sincerity shook me and I want to repay you in the same coin because true friendship can only exist in conditions of endless trust and complete sincerity, more especially because now I am horrified by the thought that you think better of me than I deserve. For me to be insincere now would be mean of me and a desire to be superior to you. Your first sin was a little boy's failing to see any divine light either in books or in people; the second sin was worse in that you said nothing about it to anyone, but I understand how difficult such a confession can be for a bold and ambitious soul: that very difficulty shows its unconscious repugnance for such a sin; and your third sin - I pity you for it but also respect you. And what about me? I was not a little boy and finally saw the divine light but averted my face from it; I said nothing as you did before Stankevich who confessed to me his...' (XI, 212)

At this point approximately thirty lines have been deleted. They are followed by Belinskii's words:

4 The number of missing lines in this letter can be judged from the Liatskii (1914) edition of the letters Vol. I, pp. 157-8 and pp. 165-6.

5 It is presumed that this referred to Aleksandra Bakunina. 
'... I am full of one feeling - a kind of sad love for you. Besides, I don't blame you or myself for that kind of reticence: it's hard to confess to that kind of thing, and if you hadn't done it first, then you'd never have heard about it from me. But - I repeat - the nobility of what you did has forced me to be noble towards you. From now on there's no need to hide anything - and that will be our sacred duty. We will know and love each other just as we are. It has been difficult for me to write these words, but it's easier now that I've written them.' (XI, 212-3)

The anguish continued for several pages more, but Michel's sins, his boyishness, his fall from grace were not specified. In view of this, one may be tempted to assume that the deletions, extensive as they are, referred to something so scandalous between the two men that their close initial friendship, leading to Michel's invitation to Belinskii to spend a holiday with his family at Priamukhino, fairly quickly degenerated into jealousy on the one part and hurt feelings and retaliation on the other. If Michel had sexually propositioned his friend, if 'love' had meant more than romantic attachment, if what was confessed was homo- or auto-erotic or sexually shameful in some form, this could explain the anguished manner of Belinskii's letter, its self-conscious magnanimity and its excessive professions of fondness. His sexual interest was directed exclusively towards women, so far as one can judge, but Michel's sexuality was less certain ${ }^{6}$ and may well have been non-existent. He was too flamboyant, exhibitionist and arrogant to acknowledge the full truth about himself.

Belinskii was the exact opposite. He loved truth and required it to be validated in love and literature. Take, for example, what he had written about truth in an earlier passage:

'Truth is in itself something abstract, it is Sein, but not Dasein: we need a certain image for realisation of this truth, and this image must be human, because man is above all truth in a visible form. Why there is a need for a human being of another sex I explain by my theory of harmony in opposites... The moment of awareness of love is the moment of inspiration, and inspiration, according to Hegel, is a sudden capacity for assessing the truth. Truth (I include here beauty and goodness) is one, but it manifests itself in different ways, just as poetry is one, but there is the poetry of Shakespeare, the poetry of Goethe, the poetry of Schiller. Everyone needs truth manifest in a recognisable form.' (XI, 210-11)

The passage is a paradigm of his thinking. The need for a definition of truth, but expressed in a human form, led him both to the need for love

6 Bakunin is known to have been infatuated by his young collaborator, Nechaev, so much so that there were scandalous rumours about the association. 
between the sexes and immediately, in his own case at least, to the need for understanding literature, the recognisable form in which truth always manifested itself to him. A few lines later he wrote about his re-assessment of Tatiana's love for Onegin (in Pushkin's Eugene Onegin); yet he himself had been living a monkish life of sexual abstinence for the past six months, aware though he was that love was the source of everything. We know little or nothing about his actual love life, whether at this time or earlier; but his relations with a certain grisette - nameless but apparently accommodating - preoccupied him during 1836 and there seems to have been at least one other relationship during his Moscow years.

By the end of 1837 he was still in vigorous correspondence with Michel Bakunin and his sisters. He was finding Michel's handwriting hard to read and signs of resentment of the latter's attitude were beginning to show. Meanwhile, in March 1838, he took up the editorship of The Moscow Observer. It became a mouthpiece for Hegelian ideas and German culture. The baleful influence of a prominent German interpreter of Hegel in the sphere of aesthetics, H.T. Roetscher, cast a long shadow over the period of Belinskii's editorship and over his own work. M. Katkov's translation of Roetscher's Das Verhaltniss der Philosophie der Kunst und der Kritik zum einzelnen Kunstwerk (The Relation of the Philosophy of Art and Criticism to the Individual Work of Art) (Berlin, 1837) produced such a list towards Hegel that the whole balance of the journal was imperilled. ${ }^{7}$

Bakunin's own contribution in the first number set the tone. In introducing his translation of Hegel's Gymnasium Speeches of 1809, which gave expression to Hegel's generally very conservative preferences for the Classical languages and strict classroom discipline, he insisted that the whole of the German philosopher's thought could be summed up in the slogan 'What is real is rational'. By any standards, even of high-brow intellectualism, such material was unlikely to attract an enthusiastic readership. ${ }^{8}$ The material might have been leavened by Belinskii's own contributions in the form of his five-act drama The Fifty-Year-Old Uncle, or A

7 He was later to denounce this academic authority on aesthetics as a German sausage and a pawn whose ideas were entirely bookish in character. See his letter to V.P. Botkin of 6 February, 1843.

8 Enthusiasm for it may be found in N.G. Chernyshevskii's Notes on the Gogol Period of Russian Literature, Article 6 (Ocherki Gogolevskogo perioda russkoi literatury: stat'ia 6). The work originally appeared as articles in The Contemporary (Sovremennik) in 1855-6. Apart from examining the role of Hegel in determining the journal's policy, Chernyshevskii also printed in footnote form Bakunin's opening article on Hegel, prohibited though he was by the censorship from mentioning the author by name. 
Strange Illness, his study of Hamlet and an initial attempt to define the significance of 18th-century Russian literature in an article on Fonvizin, which in fact hardly mentioned Fonvizin and instead devoted itself to an outline of Roetscher's aesthetic views. ${ }^{9}$

On the whole the subject-matter of the journal was simply too secondrate. This is not to deny that it made mention of Shakespeare's The Merry Wives of Windsor, the work of Fenimore Cooper, Homer and William Godwin's Caleb Williams, to name a few of the eclectic non-Russian items. ${ }^{10}$ The journal sank for want of adequate support, largely, it seems, because it was little known outside Moscow. It published a good deal of poetry, though little of value apart from the work of A. V. Kol'tsov. ${ }^{11}$ Few worthwhile examples of Russian prose writing appeared because few were available for publication. It ceased publication in 1839 after Belinskii abandoned the editorship in April.

9 The influence of Roetscher's views and their Hegelian legacy pervaded Belinskii's own criticism at this time and such terms as 'unconscious reason' (bessonsnatel'nyi razum), 'conscious feeling' (soznatel'noe chuvstvo) proliferated, but even the pretentious, heavyweight discourse could be lightened slightly by such statements as 'Thus it is precisely that love is understanding and understanding is love, because love is being present in the innermost essence of a loved object and the presence of one subject in another is none other than an understanding of that other subject,' which seems an odd form of philosophical eroticism, but should be understood by the later assertion that: 'The basis of the Christian religion is love of one's neighbour to the point of self-sacrifice. On the other hand, understanding only with the aid of reason, without participation of feeling, is deadly, lifeless and false and in no way reasonable, but merely intellectual. And if in religion a trust in feeling pure and simple leads to fanaticism, then trust in intellect pure and simple leads to lack of faith which is an abrogation of one's human dignity and a moral death.' (II, 558-9)

10 Belinskii reviewed a translation of The Merry Wives of Windsor published in 1838 and spent the entire review condemning the anonymous translator. A 'heavy' translation of Godwin's Caleb Williams (Spb., 1838) also received a review and the novel was commended for its ideas if not for its artistry. See III, pp. 69-71 and 111-12.

11 Kol'tsov (1809-42) became friendly with Vissarion Belinskii when he joined the Stankevich 'circle' and it was largely under Belinskii's influence and encouragement that the poet abandoned his early imitative 'philosophical' manner and engaged in writing 'songs' devoted to the misfortunes of the peasantry. Forced by an authoritarian father to spend much of his time in his native Voronezh, he had only infrequent contact with the literary milieux of Moscow and St Petersburg. He enjoyed a deep and enriching friendship with Belinskii largely by correspondence, the latter recognising in him a native talent of great distinction and publishing 11 of his poems in The Moscow Observer. 
A personal as well as professional catastrophe for him? It is hard to say. It was the high point of his period of so-called 'reconciliation with reality' and yet at the same time it tested his idealism almost to the limit and acted as a catharsis. He was never again to fall prey to such philosophical enticement.

\section{***}

By June and July 1838, though still in vigorous correspondence with Michel on a whole range of matters, love formed a vital component of Belinskii's thoughts. He expressed them to his friend in various ways, whether in connection with what he felt for Tatiana, Bakunin's sister, or the acknowledgement (in a letter from the end of July) that no woman had ever loved him and his face bore some kind of seal of rejection which would always frighten women away. And then tragedy struck as we learn from his letter of 13-14 August 1838 when news reached him that another Bakunin sister, Liubov', had died. She had been convinced that Stankevich was in love with her. It fell to Belinskii to write to Stankevich with news of her death at the beginning of October, by which time his relationship with Michel Bakunin had deteriorated nearly to breaking point.

One may detect the clear beginnings of this process in a letter of 10 September. Here the 'reality' with which he had been 'rationally reconciled' assumed a terrible aspect: 'Reality is a monster armed with iron claws and iron jaws and whoever willingly submits to it will be seized by it and devoured.' (XI, 285) For Belinskii himself this had a specific meaning which differentiated him from all his major contemporaries and most certainly differentiated him from his closest friends.

The reality of his life, despite his idealism, was the need to earn a living. A plebeian, a proletarian, without privilege and any source of unearned income in a society ruled by such things, he had one course open to him: he could enter government service as a civil servant. 'Service', however, was abhorrent. He relied throughout his adult life on what he earned from his writing, aided, to be sure, by financial help from friends and (in 1838, between March and October) by teaching Russian at the Konstantinov Institute of Surveying; but he never forfeited or mortgaged his independence on financial grounds. A significant part of the moral authority which has deservedly attached itself to his reputation must be attributed to the fact that he did not serve, nor did he ever seek to serve, in any office of state, however humble. He was as passionately uncompromised in the way he earned his living as he was passionately uncompromising in his views. 
In the same letter he summarised his role as: 'I am a literary man [literator], because that is my vocation and my trade.' (XI, 293) His correspondent, Michel, had no such vocation or trade. Even what he had as a guru, his concern with philosophy, had contributed to his sister's death, so Belinskii seemed to imply, and made him aware that 'even before feeling the need for love, I, being a boy, created for myself an ideal of love and loved according to the instructions given by this ideal' and so 'idealism [ideal'nost'] is my chronic illness which has taken root in my organism deeper than a haemorrhoid.' (XI, 304)

In the longest of his confessional letters to Michel (12-24 October, 1838) occupying fifty pages, most of his personal and philosophical concerns of the period received an airing, and what must strike any reader is his readiness to acknowledge a belief in God locked very closely into a belief in himself:

'I am not fearful for my future fate because I know I will be what I will be and not at all what I would want to be. There is a simple idea belonging to the mindless masses: "Everything is in God's will." I believe in this idea; it is a dogma of my religion. "The will of God" is the same as Eastern predestination, the fatum of the ancients, Christian providence, philosophical necessity and, finally, reality. I recognise a personal, independent freedom, but I also recognise a higher will. Collisions are a result of hostile enounters between these two wills. Therefore everything is and will be as it is and will be. Should I hold out - good; should I fall - so be it. I am a warrior for God. He commands and I march.' (XI, 316)

Such a confession should be taken seriously. The religious impulse was inseparably part of his commitment to literature and ideas and remained with him to the end of his life. It may have had nothing in common with the doctrines of Russian Orthodoxy or the established church, yet it was deeply ingrained in Belinskii's personality; and it contributed to the severance of his relations with Michel Bakunin in the sense that, as a conviction, it was essentially humane and humanistic, concerned above all with people, whereas Michel was concerned exclusively, it seemed, with ideas. Added to which was something inherently duplicitous in Michel's behaviour towards his friends, even towards his own sisters.

Page after page of reproach, self-justification, minute and obsessive reflection upon the many stages through which his relationship with Michel had gone concluded, firstly, with the accusation that the latter had not practised what he preached in the sense that he had not been 'completely sincere' with his friends, especially with Belinskii himself. 
Secondly, however, he offered his own self-diagnosis in a candid comparison with his erstwhile guru:

'Your blood is fiery and alive but it (if I may draw such an analogy) flows not in your veins but in your spirit; with me my spirit lives in my blood, hot and simmering, and my spirit moves within me when my blood boils and then my blood often obscures my spirit from my own eyes as well as others'. Therefore I am either all quivering, passionate, yearning love or nothing at all, so much rubbish, fit only to be spat on and thrown away, but because there are times when love lives within me, Michel, I know only too well what I am worth at other times... Abstract ideas are not my sphere, I feel stifled and horrible in that sphere, and in thought for its own sake I play a far from brilliant role; my sphere is words of fire and living images - that's where I can spread my wings and feel at home...' 12 (XI, 346)

\section{$* * *$}

The proof of these words may not be adequately validated by the work he published during 1838 and 1839 but the constraining and ultimately distorting effect of Bakunin's ideological legacy, if attributable to Hegel's influence though not strictly speaking 'Hegelian', can be seen in his articles on the anniversary of Borodino and on Menzel. These are the notorious high points in his supposed 'reconciliation with reality'. No such problems arose in any strict sense in connection with the one truly original work published at this time, his five-act drama, The Fifty-Year-Old Uncle or A Strange Illness.

It was not so much a 'drama' as a comedy. Criticism has been coy about it. This work has not become a serious part of the Belinskii canon. Written, it seems, in two or three weeks in November 1838 on the invitation of M.S. Shchepkin, it was staged as his benefit performance on two

12 The relationship between Bakunin and Belinskii has been explored by several scholars, but none has divined the relationship in psychological terms better than Lydia Ginzburg. Her commentary on this passage contains an interesting insight into the paradox of their personalities: '... Belinskii was gazing intently at Bakunin as if into a strange mirror reflecting his own contrasting image. Belinskii's self-awareness passed through a series of such contrastive juxtapositions with Bakunin's personality: love and incapacity for love, feeling and reason, a concrete apprehension of life and abstraction, timidity and despotism, self-revelation and self-importance, and so on. But these contrasts were not merely an abstract set of antitheses; they were bound up in concrete human personalities...' Lydia Ginzburg, op. cit., p. 89. 
occasions in January 1839 . Thereafter it seems to have been largely overlooked and was never staged again in Belinskii's lifetime. ${ }^{13}$

Clearly deriving from Belinskii's study of Fonvizin, Griboedov and Gogol's The Inspector General (Revizor), his drama lacked the bitter criticisim of serfdom so conspicuous in Dmitrii Kalinin. It is not difficult therefore to regard it as displaying a certain 'reconciliation with reality'. In a loose sense, as a fairly light-hearted essay on contemporary attitudes to love, it may be considered a precursor of Turgenev's work for the theatre, especially his three-act play The Bachelor and his five-act masterpiece $A$ Month in the Country. Its provincialism - intimations of the small-town ethos of Belinskii's native Chembar or Penza abound - and its reliance on stereotypical figures could not fail to make it seem derivative and boring. But in the central figures of the two orphaned sisters, Katenka and Liza, and of the fifty-year-old 'uncle' Gorskii, who had been responsible for their upbringing, a degree of heartache and genuine passion can be discerned. It must have been obvious enough to appeal to Shchepkin.

The comparisons quite consciously made between Katenka and Olga Larina (of Pushkin's Eugene Onegin) and Liza and Tatiana (in Act I) evoked deeper levels of emotional involvement than any to be found in

13 The information about the play is drawn from V.G. Belinskii, Pss., Vol. III, M., 1953, pp. 523-90, 658-74, as well as from V.S. Nechaeva, V.G Belinskii: zhizn' $i$ tvorchestvo, 1836-1841, Izd. Akad. nauk SSSR, 1961, pp. 178-92 (and elsewhere). Two editions of the drama exist: the shortened version Belinskii published in The Moscow Observer and the first - fuller - edition of the play, first published under the editorship of A.S. Poliakov (Petrograd, 1923); a version of the play with major cuts, presumably made for publication, was discovered among Belinskii's papers in 1952 and these cuts are given in the notes to the version published in Vol. III of Pss. M.S. Shchepkin, the wellknown actor generally credited with helping to lay the foundations of a realistic Russian theatre, was on terms of close friendship with Belinskii, though precisely why he should have commissioned a play from him is unclear. As a postscript it is of some interest to note that Turgenev chose the name Gorskii for the principal character in his short play of 1848 The String Breaks at the Weakest Point (Gde tonko, tam $i$ rvetsia). According to P.V. Annenkov, Belinskii himself was ashamed of his 'boringly psychological and sentimental comedy' and disliked being reminded of it. It therefore came as a considerable surprise to him to be told by the renowned philologist I. Sresnevskii that he regarded the comedy as a work of genius. (P.V. Annenkov, Literaturnye vospominaniia, Goslitisdat, 1960, p. 186.) Turgenev was less flattering. He labelled the 'comedy' a 'feeble work' in which everything was 'set out at length, tediously and lifelessly... Belinskii had no creative talent. This comedy and his article on Menzel were Belinskii's Achilles heel and to remind him of them meant to humiliate and annoy him.' Vosp. sov., p. 504. 
Fonvizin, Griboedov and Gogol. As for the crisis of conscience and profound self-disgust experienced by the elderly Gorskii when he acknowledged his love for Liza, 30 years his junior, these were sympathetically developed in monologues and confessional exchanges in the drama's final Act. It is true that there was little depth to his character while Liza's, by comparison, was by far the most interestingly drawn of all the portrayals. It may have lacked the vivacity and devil-may-care charm of her younger sibling and never fully transcended the sentimental mould in which her character was cast, but she at least deserved to be taken seriously as a study in purity of feeling on the pattern of Pushkin's Tatiana.

The play's deeper meaning emerged in the broken, exclamatory soliloquies of Gorskii. Though full of melodramatic exaggerations, they were characteristic of an elderly bachelor some twenty or more years Belinskii's senior who had been overwhelmed by the same desire for love and reciprocated passion. All too conscious of the moral ambivalence, the clash between the ideal and the real, his life had become a living hell. The deeps of feeling and meaning lurking beneath the surface of this otherwise innocuous comedy may have seemed incongruous and out of place; yet their pathology had to be respected.

All ended happily after a fashion with Liza finding her real love in Mal'skii and Katenka in the landowner Korkin. All received Gorskii's blessing after his recovery from the 'strange illness' of his love. But happiness... Can they hope for happiness? 'Is it possible there's no complete happiness on earth?' (III, 589) asked Liza at the end. 'Enough... enough,' was the reply. 'We'll wait and see... Now it's time to say goodbye... Be happy, so happy that people can finally believe there is such a thing as happiness on earth... As for me, shed a tear when I die and give me a smile when we see each other...' (III, 589-90) As for the snake that had gnawed at Gorskii's heart, he would tell it to keep quiet: he had done what he had to do.

The play offered a morality and a moral emphasising individual duty. Gorskii struggled with his conscience and eventually surrendered his heart's desire to the sanctions of youth and convention. Nations should behave in the same way, or so Belinskii seemed anxious to emphasise, for a nation was by implication to be interpreted and understood as an individual person, as a personality (lichnost').

He was preoccupied by this view of nationhood in several articles at this time. In the wake of the twenty-fifth anniversary of the Battle of Borodino (of 1812), recognisably the greatest feat of Russian arms in the 19th century, several patriotic works appeared. Of these The Anniversary 
of Borodino by V.: Zhukovskii and F. Glinka's Notes on the Battle of Borodino (Reminiscences of 1812), both of 1839 , prompted suitably patriotic responses which explored Belinskii's ideas on Russian nationhood in several remarkable ways.

He demonstrated what might be called a rational patriotism attempting to be real which expressed itself at its most extreme in a dotty eulogy of the tsar and the historical role of tsarism. It had, of course, more than a grain of truth in it. When Belinskii insisted that government in Russia had 'always been in advance of the people' (III, 246), he was not far wrong. Peter the Great, always Belinskii's hero, had changed Russian orientation forever by turning it towards the West. But when, in delivering his panegyric to tsarism, Belinskii went further and lyrically described the authority of the tsar as always being 'the living well-spring in which the waters of renewal never dried up, the sun whose rays, emanating from the centre, spread throughout the sinews of the giant corporation of the body politic and permeated it with living warmth and light'; when he wrote: 'In the tsar is our freedom, because it is to him we owe our new civilisation, our enlightenment, just as we owe him our life'; when he concluded by acknowledging: 'It is time to recognise we have a rational right to be proud of our love for the tsar, to be proud of our limitless devotion to his holy will, in the way the English are proud of their state edicts and their civil rights, just as the North American States are proud of their freedom' (III, 246-7), he was justifying the arbitrary rule of autocracy in terms clearly more appropriate to a propagandist and apologist than to a true patriot.

His attitude to literature seemed similarly apolitical at this time. His article on 'Menzel, critic of Goethe' has been generally regarded as a defence of the autonomy of literature in much the same terms as his Borodino article had been a defence of autocracy in politics, but it stated something distinctive and consistent in his thinking despite appearances to the contrary. The commitment to literature as an independent repository of the highest human ideals, ideals, that is to say, consistent with the finest artistry as well the highest morality, was a matter of faith for Belinskii. The article argued for literature's independence from society, objecting, for instance, to Menzel's criticism of Goethe for not mentioning the French revolution in his work, while nonetheless insisting that 'Art is the reproduction of reality; consequently its task is not to correct or embellish life but to show it as it is in fact. Only in these circumstances are poetry and morality identical.' (III, 415) Art, in short, should not serve society otherwise than by serving itself.

Yet probably the nub of Belinskii's objection to Menzel was to be found in a sentence towards the end of the article. He quoted Menzel as 
claiming that he took great pride in never having changed his mind. For Vissarion Belinskii this represented a comic excess of arrogance. Struggle, change, search were essential in the dialectic of progress. The poet should struggle, guided always by his visionary nature, to achieve ever higher standards, ever renewing himself in order eventually to arrive im frischen Goetterreich (as Goethe put it), in the eternally spring-like kingdom of the Gods.

Needless to say, as a critic Belinskii made mistakes; and one of his biggest mistakes occurred in his assessment of the famous satirical comedy of post-Napoleonic Moscow life, Griboedov's Woe from Wit (Gore ot uma), a second edition of which appeared in 1839. His review of this printed version of the play rather than a review of a stage performance may have led him to misinterpret the work in its satirical essentials, but other, more fundamental, reasons may be adduced.

Published unsigned in the January 1840 issue of Fatherland Annals and the first major work Belinskii wrote for Kraevskii's journal, the article was most likely conceived and largely written the previous year before he left Moscow to take up permanent residence in St Petersburg. Heavily influenced by Hegelian terminology, in its opening pages it had the air of a treatise. Belinskii's lapidary manner frequently lacked the humour and lightness of tone that characterised his letters and the pomposities of his article on Woe from Wit were conspicuously out of keeping with the comedic elements in Griboedov's masterpiece. This is not to say that he did not make several telling points.

In the opening discussion of the Classical and Romantic periods in the evolution of art, their respective ideologies and ideals, an important role was ascribed to Christianity as a civilising influence. This influence, Belinskii insisted, had persisted to the present day in the sense that 'whatever exists today, everything that contemporary humanity can take pleasure in and be proud of, sprang from the fertile seed of eternal, intransient words of the divine book of the New Testament,' (III, 426) including love and respect for human personality and the courage to sacrifice body and soul for the downtrodden, as well as the idealisation of women as representatives on earth of love and beauty. Art had therefore only achieved its full meaning in the present age, as a reconciliation of Christian content with the plasticity of classical form. This led to a new balance between form and idea, a new reconciliation, just as inimical to romantic art as to classical. Reality had now become the watchword and slogan of the poet who should 'think in images' (III, 431) in order to demonstrate - never to prove - the truth; and consequently a similar inherent ambivalence informed the supposed contrast between the tragic and the comic 
in art, because elements of the tragic, so the argument ran, resided in reality, in affirmation of life, whereas the comic derived from a phantom life which was merely an objective reality, in negation of life.

The terminology, like the thinking, had a cloudy indeterminacy. The most well-intentioned and forgiving reader could find the argument less than lucid. Yet lightning flashes of revelation had a way of suddenly illumining the literary works under consideration.

There was an assumption - more or less consistently argued - that a work of literature, for it to be considered artistic, should depict a particular closed world of its own. Gogol's The Inspector General (Revizor) was a case in point. Belinskii's analysis of this classic comedy was masterly, more masterly and entertaining, perhaps, than his rather pedagogic aim, when stated, might have made it seem. 'Our aim,' he wrote, 'was to hint at what an artistic comedy should be. For this reason we have tried to hint at the idea behind The Inspector General and consequently to draw attention not only to the the naturalness but also to the inevitability of the mayor mistaking Khlestakov for an inspector general, a mistake comprising the plot and denouement of the comedy and through all this to point to the possibility of the play being a whole entity (Totalitaet), a particular closed world of its own.' (III, 470)

This notion of a work of art having an 'enclosedness' (zamknutost') as a prerequisite of its artistic value was noteworthy, ${ }^{14}$ yet, applied to Griboedov's comedy, it tended to find the work wanting for what, with hindsight, could be regarded as the wrong reasons. Belinskii acknowledged that Woe from Wit had many brilliant features. As a verse play it was technically matchless, its language contemporary and conversational, its verbal wit such that many of its lines had become proverbial sayings and it showed, above all, 'a talent that was clear, living, fresh, strong and powerful...' (III, 472) With recommendations of this kind, why bother to criticise the work?

The comedy had, of course, certain manifest absurdities. Chatskii, the hero, for instance, returned to Moscow, still apparently in love with his

14 The term zamknutyi/zamknutost' was Katkov's translation of the German abgeschlossen', described by Sigurd Fasting as 'Roetschers Bezeichnung der organischen, konkreten Einheit von Gehalt und Gestalt im Kunstwerk.' Fasting, S., V.G. Belinskij. Die Entwicklung seiner Literatur Theorie I, Scandinavian University Books, 1972, n. 29, p. 240. A. Lavretskii in his Estetika Belinskogo, M., 1959 devoted a section to zamknutost' (pp. 108-12) which largely denied the influence of Roetscher but claimed that the term was virtually synonymous in Belinskii's thesaurus of such terms with wholeness based on a unity of form and content. 
childhood sweetheart Sophie after several years absence abroad, and called on her at six o 'clock in the morning! He had not shaved or changed his clothes but assumed he would receive an instant loving welcome. Did he genuinely love Sophie? Belinskii asked; and all readers or spectators of the play might well have their doubts. If he did not, then the comedy as a whole had no unifying idea and Chatskii himself must be branded as shallow, simply a loud-mouth, a phrasemonger, an idle chatterer constantly engaged in profaning everything sacred about which he speaks. So the conclusion reached was that 'In general Woe from Wit is not a comedy in the sense of being a work of art, a single whole enclosed in a world of its own in which everything springs from a single source - its basic idea...' (III, 484) Despite this, even if classified as a 'satire' (which Belinskii insisted could not make it a work of true art), it had claims to be a 'poetic' work in the highest degree - a confusing judgement which did little to enhance the critic's reputation for acumen or insight but acknowledged that Griboedov's masterpiece was a lesser work than Gogol's $A n$ Inspector General.

There was some justice in Belinskii's ambivalence and confusion. The satire of Moscow types in Woe from Wit lacked the crisp, comedic directness of Molière and Chatskii's twin roles of ardent lover and corruscating wit sat oddly together. As a playwright of sorts in his own right, Belinskii was entitled to be critical. If he could not discern the depth of the satire or admit publicly to its historical relevance, he had a perfect right to question whether any true feeling, let alone love, impelled Chatskii in his relations with others and to this extent he could brand both the play and its hero as lacking in that emotional honesty which, to him, was always so essential in his relationships and so precious in his assessment of true value in a work of literature.

This critique, however muddled, was brilliant in its discursive concern for larger meanings. It demonstrated Belinskii's rare ability to confront and define issues of literary criticism over a broad spectrum encompassing Classicism and Romanticism, the role of Christianity, poetic truth and its relation to reality and the difference between comedy and tragedy. No other Russian of his generation could match his competence. Similarly, no other Russian of his generation deserved a wider forum in which to express himself. To find such a forum he had to move to the imperial capital where his most famous work as a critic was to be done. He would always retain a slightly ambivalent fondness for the Moscow of Griboedov's Woe from Wit, his - Belinskii's - alma mater and the place where he achieved his earliest success, although later in life he would grow to dislike it as the source of a hypocritical, anti-Western, Slavophile culture. 

Chapter 4

\section{St Petersburg, Fatherland Annals and A Hero of Our Time}

He had long wanted to move to St Petersburg and there had been soundings as early as 1837 in a letter to A. A. Kraevskii, but it was not until the summer of 1839 that terms could be agreed through the good offices of his friend Panaev. Kraevskii was by then proprietor and editor of Fatherland Annals (Otechestvennye zapiski), a leading St Petersburg so-called 'fat journal'. In late October Belinskii accepted the post of literary critic on the journal and travelled to St Petersburg in the company of Panaev and his wife.

The move was professionally crucial to him. It gave him an income, even if at best only poor, and it gave him status. Fatherland Annals under the management of Kraevskii was intended to be a major journal covering every branch of life in Russia and the West. Kraevskii himself was hard-nosed as a proprietor but no literary critic and piled work on his unfortunate employee with little thought for the resultant strain. Despite this, the relationship between the two men was warm and remained so, relatively speaking, for the first few of years of Belinskii's employment.

St Petersburg was a shock. A 'European' capital in appearance, the creation of his hero, Peter the Great, it was in many ways an artificial city built as the capital of empire and designed by its architecture to subordinate nature and humanity to the apparatus of statehood as if to a godhead. The individual could be dwarfed by it. The poor Evgenii chased through the streets of St Petersburg in Pushkin's narrative poem 'The Bronze Horseman' was merely the first of many literary victims of the 'fantastic' city. Like Gogol's wretched Akakii Akakievich of The Overcoat or Dostoevskii's Goliadkin of The Double, Vissarion Belinskii quickly felt the same oppression and impoverishment of spirit, the same sense of alienation. 
The worst aspect of his new-found state was loneliness. He acquired new friends but they were not soul-mates. He missed the easy-going habits of Moscow. What he found in St Petersburg, as he put it in a letter to Botkin of 3-10 February 1840, was 'a frightful cliff face against which my beauty of soul (prekrasnodushie) came to grief.' (XI, 437) Once the initial shock of the change had passed he acquired a deeper awareness of society, a fuller sense of literature's role in relation to it and a certainty that the answers lay less with philosophy than with politics.

Jokingly perhaps he was to speak of literature as 'a governess of society' (XI, 453, letter to Botkin, 18-20 February, 1840) and he was to compare his own role as a journalist with that of a university professor. A pedagogy of manner as well as of purpose always motivated his criticism, sometimes to the point of obscuring his genuine love of Russian literature. Though the idea as well as the artistic accomplishment in a work of literature remained all-important, the emphasis in his criticism was increasingly placed on the human and humanitarian relevance of literature to life and society. In a specific sense for Belinskii in 1840, the 'year of crisis' in his life, ${ }^{1}$ the break with the past came in two ways, both personal and ideological. Firstly, there was the comic circumstance of his final break with Michel Bakunin.

He described the 'drama' of it graphically, with the artfully faux-naif manner of a Dostoevskian narrator, in a letter to Botkin of 12-16 August 1840. There were three participants: Belinskii, Michel and Katkov. Belinskii learned with some anxiety that Michel was coming to St Petersburg before leaving for abroad and wished to 'explain' things to him, a situation which Belinskii felt sure would involve a good deal of swearing and bad language on his part. He was therefore relieved to have Katkov visit him with the news that Michel had actually arrived the previous night and stayed with Panaev who could not conceal his coldness towards him (related, one assumes, to Michel's persistent scandalmongering, especially at that time about a romantic entanglement between Maria Ogareva and Katkov who happened also to be staying with Panaev, although

1 Nechaeva devoted a chapter to what she entitled 'The Year of Crisis' (V.S. Nechaeva, op. cit., Vol. III, Izd. Akad. nauk, 1961, pp. 293-315.) though she attributed the fairly abrupt change in orientation of Belinskii's ideas to the influence of Herzen. Judging from his extant correspondence, there is no direct evidence of this. 
Michel did not know this). Belinskii was glad to have Katkov with him when Michel arrived to see him:

'... Suddenly I looked out of the window and there, in the courtyard, was his long, ugly figure in an appallingly filthy, outlandish peaked cap asking for me. I shouted at him wildly from the window: "Bakunin, here!" My heart beat like mad. Finally he came in and I ran into the hallway to take his hand and stop him from kissing me, but he nonetheless thrust his rough hard lips at mine and, going through the bedroom, entered my study where he came face to face with Katkov.

'Katkov began thanking him for sticking his nose into his business. Bakunin, as if suddenly struck by fire from the heavens, staggered backwards into the bedroom and collapsed on to a divan saying something about "Facts, a few facts, I only wanted a few little facts to be known, my dear sir!", his face and voice changed out of all recognition and trying hard to be nonchalant.

" "Facts, indeed! You've cheapened and debased me! You're a scoundrel, sir!" Bakunin sprang to his feet. "You're a scoundrel yourself, sir!"

"Eunuch!"

'This accusation affected him far worse than being called a scoundrel and he was violently startled as if he'd received an electric shock. Katkov gave him a shove with the obvious intention of starting a fight. Bakunin seized his stick and a struggle ensued. I cannot remember what I did exactly except shout "Stop it, gentlemen, what on earth are you doing!" as I stood stock still in the doorway. Bakunin turned away and waved his arms without so much as a glance at Katkov. Seizing his chance, he struck Katkov across the back with the bamboo stick you had given him, but that outburst of strength and courage was all he could manage and Katkov delivered a couple of sharp slaps to his face. Bakunin's state was now all the more shameful because Katkov thrust his face directly into his and Bakunin bent double in order to hide himself. He had been shouting out during the struggle:

"'If that's how you want it, then we'll fight a duel!"

"Having got his own back by hitting Bakunin twice in the face, Katkov heeded my pleadings and retreated to the study. I closed the doors. Bakunin's peaked cap was lying on the study floor and my bedroom was covered in plaster which had come down from the ceiling during the row.'

Belinskii was fully on Katkov's side over this incident, although he could not help feeling sorry for his erstwhile friend despite Bakunin's repellent ugliness - 'His face was pale,' so the description ran on, 'yet his cheeks had two unpleasantly crimson marks on them and his 
usually repellent lips were literally shaped into a parallelogram,' so much so that Belinskii wondered how his attractive sisters could ever have made themselves kiss him on the lips. The episode, of course, ended their relationship and the threatened duel came to nothing. (XI, $541-3)^{2}$

Bakunin was now a 'eunuch' in an ideological sense, impotent to exert any formative influence over the Belinskii who had once been his closest disciple. This was the first decisive break of his Petersburg years. The second was more far-reaching and involved a basic re-orientation of his ideological sympathies. He now renounced his earlier 'reconciliation with reality' or as he put it in his letter to Botkin of 4 October 1840: 'I curse my disgusting striving to achieve reconciliation with disgusting reality!... Long live reason and let darkness be cast out, as the great Pushkin exclaimed! For me now human personality is above history, above society, above humanity!' (XI, 556)

The emphasis upon human personality led him to change his mind about the focus of literature. For one thing, it made him reassess much more positively Griboedov's Woe from Wit (Letter to Botkin of 1 March 1841) and the role of Chatskii. For another, in the same letter it led him to declare boldly that 'The fate of the subject, of the individual, of the person is more important than the fate of the whole world and the health of the emperor of China (i.e. of Hegel's Allgemeinheit)...' (XII, 22) This was a repudiation of the Hegelian notion of the universal in favour of an assertive faith in humanity that anticipated one of the greatest nihilistic moments in Russian literature. Dostoevskii expressed the idea through the most paradoxically nihilistic of his heroes, Ivan Karamazov. He described to his brother Aliosha why he refused his entry ticket to God's world and hoped to write a poem about Christ's second

2 Belinskii's account, slightly shorthanded in its epistolary form, has been reparagraphed in my translation. In his biography of 1937, E.H. Carr delighted in this episode, which cast Bakunin in such an unfavourable light (E.H. Carr, Michael Bakunin, London, 1937, pp. 86-7). That Belinskii was a hostile witness is true, but he could hardly be considered unreliable; a later study of Bakunin, Aileen Kelly's, dismissed Belinskii's 'ironic' version of the affair by claiming that he 'said in two pages what could have been said in two words'. (Aileen Kelly, op. cit., 1982, p. 64). One wonders. Maria Ogareva was the wife of Nikolai Ogarev, but her reputation was far from unblemished and her unfaithfulness notorious, as E.H. Carr pointed out in his entertaining The Romantic Exiles (London, 1968, pp. 143-50). 
coming. ${ }^{3}$ Belinskii addressed Hegel in an approximately similar anguished, assertive spirit bordering on blasphemy:

'If I ever succeeded in climbing to the highest stage of development, I would ask you to give me an account of all the victims of conditions of life and history, of all the victims of accidents, of superstition, of the inquisition of Philip II and so on and so forth; otherwise I would throw myself down from that topmost place head first. I do not want happiness even as a gift if I am to be uneasy on account of each and every one of my blood brothers who is bone of my bone, flesh of my flesh.' (XII, 23)

He had passed through a crucible of doubt since coming to St Petersburg and was ready to admit that a year previously his thinking had been diametrically opposed to the way he thought now. Whether or not this was a matter of happiness or unhappiness, whether or not it was one and the same thing to think and feel, to understand and suffer, he could not say; he was only sure he had to be apprehensive of fanaticism which, in political terms, now meant that he found the government system of the United States the most sensible in the world, followed by that of England and France. In other words, faced by the imperial, autocratic realities of St Petersburg, he began to purge himself of his former German-orientated sympathies. Liberalism and parliamentary democracy became temporary watchwords.

They remained words, no more, because the true focus of his activity was still literature and its human and social relevance. The focus was sharpened by the appearance of Lermontov's novel A Hero of Our Time (1840). The most comprehensive and sympathetic critique of a major

3 The Brothers Karamazov, Part II, Book V Pro and Contra, Chs iv and v, Bunt and Velikii inkvizitor. Belinskii also confessed in the same letter to his friend Botkin (of 1 March 1841) that 'the philosophy of Hegel was only a moment, though a great one, but that the absoluteness of its results wasn't worth a shit, that it would be better to die than be reconciled with it... The subject [for Hegel] is not an aim in itself but a means of giving momentary expression to the universal, and this universal in relation to the subject is a Moloch, for when it has finished showing off in the subject it casts the subject off like an old pair of pants. I have particularly important reasons for loathing Hegel because I felt I was being faithful to him (emotionally) in reconciling myself with the servile reality [of Russia]...' (XII, 22) Belinskii's use of the expression raseiskoi deistvitel'nosti (i.e. 'of servile reality') in this and other contexts has always proved hard to translate, since the epithet (an apparent neologism) tends to suggest both 'servile' (in reference to serfdom) and 'racist'. Other commentators have noted the similarity between Belinskii's statement in his letter and the Dostoevskian text, notably Berdiaev in his The Russian Idea (London, 1947, pp. 75-7). 
contemporary work he ever wrote, Belinskii's review of the novel was undoubtedly influenced by the happy circumstance of an extended private meeting with Lermontov himself. It occurred while the latter was detained in the Ordinance House in St Petersburg as a consequence of a duel, before his final exile to the Caucasus and death the following year. Whether or not the men had met frequently in the editorial office of Fatherland Annals must remain in doubt, ${ }^{4}$ but they had certainly met once before - in Piatigorsk - when they had violently disagreed. Now, over a period of approximately four hours, they struck up an acquaintanceship which came as a revelation to Belinskii.

He found Lermontov had profound aesthetic feeling allied to a sensitive poetic spirit. They discussed English literature, during which Lermontov condemned Walter Scott for being 'dry' and preferred Fenimore Cooper because there was more 'poetry' in his work, a verdict which may seem oddly perverse by any standards. Still, Belinskii felt he had seen the 'real' Lermontov. 'He's a real character!' he is said to have exclaimed; and what this meant was that he was Pechorin to the life. ${ }^{5}$

It was a unique experience. Belinskii now had the opportunity to confront a literary hero in reality. Beneath the sardonic, outwardly supercilious surface of Lermontov, the Byronic poseur, he was able to encounter the sensitive, vulnerable, introspective soul of Lermontov, the poet, and discern the way he had explored himself and his own complex mindset in the probing self-portrayal of Pechorin offered in the novel. But the novel itself, as Belinskii was quick to note at the opening of his review, perfectly characterised the state of Russian literature at that time. Unlike its European counterparts, Russian literature lacked depth and tradition. It consisted of sunbursts of strong and even great artistic talents against the background of a generally characterless mediocrity. Lermontov's A Hero of Our Time was precisely such a sunburst.

Belinskii recognised that the novel was essentially personal and subjective, if not exactly autobiographical. Yet pedagogy, if not common sense, demanded that he should endeavour to explain it in terms of art as a

4 According to Panaev, who gave the fullest account of this meeting between Belinskii and Lermontov (I.I. Panaev, Literaturnye vospominaniia, Gos. izd. khudozh. lit., 1950, pp. 136-7), they had met frequently, but Kraevskii himself disputed this (Ibid., n. 159, p. 386).

5 Letter of 16 April 1840 to Botkin: 'Pechorin is the man himself as he is. I argued with him and I was pleased to have seen in his intelligent, cool and malicious view of life and people seeds of a profound belief in the dignity of the one and the other. I told him this. He smiled and said: God grant!' (XI, 509). 
work possessing a unity of idea. This meant resorting to Roetscher and the legacy of Hegelian aesthetics and involved him in describing at considerable length what he came to refer to as the laws of 'particularity' (zakon obosobleniia) and of 'enclosedness' (zakon zamknutosti) as they applied to what he called the 'individual generality' (individual'naia obshchnost') of every novel and could easily be applied to A Hero of Our Time.

Herbert Bowman has offered an excellent gloss on this idea when he wrote, à propos of Belinskii's earlier review of Woe from Wit, that 'it thus becomes the work of the true artist to build a miniature world-in-itself, an imaginative duplication of the self-contained world of actuality, in which everything that exists is the unfolding of an inner rationale. ${ }^{6}$ Ideally this was what Belinskii aimed to demonstrate in reviewing the novel, for the idea of 'a miniature world-in-itself' (exhibiting, that is to say, the idea of 'enclosedness') was one he emphasised at both the beginning and end of his review. If no 'inner rationale' was ultimately discerned, this was due as much as anything to the abandonment of all 'reconciliation with reality' and a repudiation, very largely, of the terminology associated with it. The confrontation with Pechorin and the manner of his portrayal meant for Belinskii a confrontation with himself and his previous ideals.

The confrontation with the novel meant a conscientious outlining of its content for a readership in need of guidance. Hence not only were there illustrative quotations but also commentaries and, here and there, especially in regard to Pechorin's behaviour towards women, a certain tone of rather high-minded moralising lightened by perceptive insight. Was Pechorin really in love with Bela? Belinskii asked in anticipation of a hostile reaction from readers aligned against the hero's callousness. 'Love,' he declared sententiously, 'needs a rational content... love is the harmonious blending of two related natures in a sense of the eternal.' (IV, 216) Hardly therefore what Pechorin may have had in mind, but even if he might have grown tired of Bela's charms after a few months, and even if her love for him was a full glass of some sweet nectar she would want to swallow to the last drop, his soul, so Belinskii tended to suggest in mitigation, demanded not just a glassful but a whole ocean of such sweetness. Similarly, but with greater sympathy for the heroines in question, Belinskii examined at some length Pechorin's relationships with Vera and Princess Mary.

Of course, Pechorin played the role of 'seducer with nothing better to do' (IV, 234) in his relationship with the innocent and impressionable

6 Herbert Bowman, op. cit., p. 119. 
princess. To Belinskii what mattered were the hero's candour and honesty in confronting himself, his own reality and the reality of the small provincial world of Piatigorsk. The kingdom of truth about himself and his world was a promised land for Pechorin. Art had to show this inner struggle because it was only in such passions and contradictions that the rational and the human became truly evident. Consequently, 'we must demand of art that it show us reality as it is because, no matter what it is, this reality, it will tell us more than all the fictions and teachings of the moralists...' (IV, 237) Art was given the task of showing events in accordance with the laws of a necessity comprehended as rational in order to demonstrate that a man was to be judged by his deeds, that there were necessarily dissonant elements out of tune with the harmony of his moral spirit, that harmony could be restored or shattered at will.

Belinskii's was not ultimately a critical verdict on Pechorin. In the critic's eyes, here was a man of mature self-awareness, disillusioned, cynical, conscious of his twofold nature which constantly judged his actions, as reflective and persecuted by his conscience as a Hamlet, yet in potential strong, sensitive and capable of realising the positive role he might eventually play in life. There was much that was false in Pechorin's ideas, his emotions were distorted, but all this was compensated for by the richness of his nature. Like Pushkin's Onegin, he reflected a necessary moment in the development of humanity or society; Pechorin was 'the Onegin of our time' (IV, 265), the literal hero of our time. At which point Belinskii achieved the most brilliant and memorable summary of the respective heroes' importance:

'In as much as Onegin is superior to Pechorin artistically, Pechorin is superior to Onegin in his ideas.' (IV, 266)

The 'unity of idea' which Belinskii sought to discover in the novel as a work of art strictly speaking eluded him at the end of his review. The novel, 'striking in the astonishing unity of its feeling, does not strike one at all with its unity of idea and leaves one without any perspective... In this novel there is an astonishing enclosedness in the way it is made, but not that higher, artistic enclosedness which is communicated to the creation through the unity of its poetic idea.' (IV,267) It was a defect which made the novel distinctive as a sad reflection on the time of which Pechorin was the hero. It related directly to contemporary social questions and the unity of feeling which pervaded it was consistent with the indefiniteness and contradictions inherent in Pechorin's portrait.

By contrast with Pushkin's Eugene Onegin, in which all the parts were organically interlinked, A Hero of Our Time had several frames set within one large frame which comprised the novel's title and the unifying role of 
the hero. Although this diversity may have adversely affected the portrayal of the female characters, especially in 'Princess Mary', Belinskii was enthusiastically ready to acknowledge the poetry and vitality of the work as a whole. In a purple passage he described the style as at one moment like 'a flash of lightning, at another the blow of a sword, or like pearls poured down on velvet!' (IV, 269)

The review ended with Belinskii permitting himself to speculate. In a final coda which had an evident moralising aim, he conjured with the notion that Pechorin might come to respect the laws of morality and more importantly - learn through a resurrecting love how to overcome his mistrust of the mystery of life and love and know the dignity of womanhood. There was even a suggestion that such a rehabilitation might be anticipated in the Preface to Pechorin's Journal where the surrogate 'author' claimed to possess a thick notebook relating to the rest of the hero's life. Such may have been the promise latent in the hero, but it mattered less than the promise of Lermontov's work as a whole. It provided evidence enough of something specifically Russian in literary terms and was reinforced by the appearance in the same year of a collection of Lermontov's poems.

This review entailed asking the all-important question: What is poetry? and again summoned into being the ghost of Hegel in trying to answer it, though halfheartedly and with pronounced emphasis on the individual rather than on the universal. What is more, the critical voice now seemed more assured and bold for all its assertiveness:

'Each person is a separate and particular world of passions, emotion, desires and awareness; but these passions, this emotion, this desire, this awareness are... attributes of human nature common to all people. And so whoever has more of the universal is more fully alive; whoever is without the universal is one of the living dead... For someone in touch with the universal, personal gain and everyday domestic issues are secondary, while nature and humanity are of the greatest concern. Such a person is an expression of the universal and thirsts after compassion for the nearest and dearest, the quivering joys of love, the simple happiness of friendship, the excitements, storms and difficulties of life, the struggle with obstacles; such a person understands everything, reacts to everything, and in gilded palaces, in the midst of wealth and luxury, will hear the groans of beggars and the needy and find them heartrending and not turn away...' (IV, 486)

A clear example of the way philosophy had turned naturally into philanthropy in Belinskii's thinking, this passage invited the reader to understand poetry as inherently a matter of compassion, of reaching from 
the inner experience towards an externalising of the universal in society and social relations. Patriotism itself came within this remit: it had to be love for one's country linked to love of humanity. And poetry was the agent of inspiration, more alive in its own life than was life in reality because the poet, the artist, while acknowledging what Belinskii called 'the great truth' that the real was rational and the rational real, had only to be concerned with a rational reality, of which he was not the servant but the master, to which he brought his own ideals and which he transformed in the light of those ideals. So that "poetry is life predominantly, the essence of it, the most delicate ether, so to speak, a triple-extract, life in its quintessential... Poetry is the beating pulse of earthly life, its blood, its fire, its light and its sun.' (IV, 493-4)

Somewhat grandiosely within this framework the poet himself was to be esteemed not merely as a passive echo of the real world but as an organising force, impressionable and irritable and always active, shedding electric sparks at the slightest contact, suffering more compassionately than others, experiencing pleasure more vitally, loving more passionately, hating more fiercely and, in short, feeling more deeply. The poet possessed a nature in which the passive and the active aspects of the human spirit were developed in the highest degree. But poetry had no aim beyond itself. This did not alter the fact that the greater a poet might be, the more he belonged to the society in which he was born and the closer his evolution, direction and particular talent related to the historical development of that society.

Lermontov met this criterion much as Pushkin had done, but his poetry was dominated by a sense of hopelessness. The reader could not help being struck by its joylessness, its disbelief in life and human feeling. Although it exhibited a thirst for life and a surfeit of emotions, Pushkin's delight in the feast of life was nowhere discenible in it. It asked questions which darkened the soul and froze the heart.

With a certain guile Belinskii chose to begin his survey of Lermontov's poetry not with the poet's more personal and pessimistic lyrics but with an extended examination of his long dramatic poem 'The Song of Tsar Ivan Vasilievich, the young bodyguard [oprichnik] and the bold merchant Kalashnikov.' The subject was semi-historical. It introduced the figure of Ivan the Terrible as stern, worldy-wise but ultimately harsh. Couched in a folksy and cleverly sustained ternary metre, the story concerned the young bodyguard's attempt to seduce Kalashnikov's young wife, the husband's vengeance upon the would-be seducer and the Tsar's decision that Kalashnikov should be executed. The implications of such autocratic justice would not be lost upon any thinking reader living under 
the autocratic regime of Nicholas I and could be seen to have particular relevance to the 'lines written in blood,' as Belinskii put it, of Lermontov's 'The Thought' (Duma).

The examination of the more embittered and pessimistic lyrics that followed achieved heights of exclamatory praise in Belinskii's assessment of them. It culminated in a lengthy study of the fine narrative poem 'The Novice' (Mtsyri). The Caucasian setting naturally invited comparison with Pushkin's 'Prisoner of the Caucasus' and led the critic to talk of that region as 'the cradle of our poetic talents' (IV, 543) - a reference, among other things, to Lermontov's as yet unpublished (and unfinished) poetic masterpiece, his narrative poem 'The Demon' ${ }^{7}$ Nothwithstanding the romantic settings and ostensibly escapist or metaphysical subjectmatter of the poetry, and equally notwithstanding the vague imagery and imprecision he identified in it, Belinskii proclaimed Lermontov 'an omnipotent master of the kingdom of life's phenomena' who 'reproduces them like a true artist; he is a Russian poet in spirit - the past and the present of Russian life dwell in him; he is also deeply versed in the inner world of the spirit.' (IV, 545) The review concluded with a grandiloquent paean of praise for the poetry and the clear implication that Belinskii himself was the only true arbiter of the poet's originality and greatness.

Despite such rhetoric, the main purpose of his concern for Lermontov's work in both prose and poetry was well served by these two reviews, which represent a high point in his achievement as a critic. The review of $A$ Hero of Our Time had particular significance in its twofold demonstration of the novel's importance in the evolution of a truly national literature and evidence for a specifically Russian contribution to Europe literature as a whole.

7 For a particularly interesting and phallic discussion of Lermontov's relation to the Caucasus as well as Belinskii's, see Chapter 8 of Susan Layton's Russian Literature and Empire: Conquest of the Caucasus from Pushkin to Tolstoy, Cambridge U.P., 1994. 



\section{Chapter 5}

\section{From Socialism to Dead Souls}

More than once in his letters Belinskii lamented his inability to write as well as he hoped, since the pressure of reading and reviewing left him scarcely any time to reconsider or recast. His weak tubercular chest increasingly meant he had to write standing up, which often led to exhaustion. ${ }^{1}$ More keenly still he lamented the lack of love, of female companionship, telling N.A. Bakunin (letter of 6-8 April, 1841) that he had 'a tantalising thirst for love' and:

'There was a time when woman was godlike to me and I found it odd to think of her being able to lower herself enough to love a man, even if he were a genius; but now she's not godlike, she's simply a woman, no more, no less, a being I cannot look at without a certain awareness of my superiority based not on my personality but on the fact of my manhood. We are good but they are better. The best of them are without doubt those who are capable of making a man happy, of blending with him and losing themselves in him without thinking about it, without reservation, in the fullness of madness, which is the only true life.' (XII, 39)

By 1841 he was accustoming himself to living in the imperial capital and even became quite a patriot for the city without feeling truly at home or accepting it politically. 'All my life,' he candidly admitted, 'is in my

1 Annenkov recalled how he would spend days and nights standing before his raised writing bureau or lectern: 'The fairly narrow, tropically warm study with its two windows, between which the raised writing bureau was placed, had a couch set against the opposite wall at a distance of four or five paces with a little table at its head. Belinskii almost always wrote, as was recommended for journal articles, on one side of the sheet and cast it aside the moment he had finished it. He would then lie down on the couch and pick up a book, after which, turning over the dried sheet, he would again seize his pen without these interruptions to his reading and writing affecting his train of thought.' P.V. Annenkov, Literaturnye vospominaniia, Gos. izd. khud. lit., 1960, pp. 172-3. 
letters,' (XII, 42) and his letters showed him veering between extremes in his hopes and convictions. Should he marry, for example? Writing to his friend Botkin (28 June, 1841) he asked: 'Marriage, what is it? It is an institution beloved of cannibals, maneaters, Patagonians and Hottentots justified by religion and Hegelian philosophy.' (XII, 53) It was an extreme to which he obviously did not wish to commit himself at that moment, but by 8 September, writing to the same correspondent, he admitted he was committed to a different extreme, having only recently abandoned the excessive conservatism of his Hegelian period:

'You know my nature: it is eternally at extremes and never gets to the centre of an idea. I abandon an old idea painfully and with difficulty and then deny it utterly and go over to a new one with all the fanaticism of a proselyte. So I am now at a new extreme, the idea of socialism, which has become for me the idea of ideas, the reality of realities, the question of questions, the alpha and omega of faith and knowledge. Everything is from it, for it and towards it...' (XII, 66) And again, while passionately embracing the notion that 'the soil of every reality is society,' (Ibid.) he was condemning Hegel's universal as 'a dead, masturbatory dream' and simultaneously acknowledging that it was not for 'us', meaning Botkin and himself and others of their circle, to become husbands and fathers of families. After an extensive and anguished examination of their personal relations, he admitted that his motto now was 'social consciousness [sotsial'nost'], social consciousness - or death!' (XII, 69) but the main problem was his conscience:

'What's it to me that $I$ understand ideas, that I appreciate the world of ideas in relation to art, to religion, to history when I can't share this with all those who should be my brothers in human terms, my nearest and dearest in Christ, but who are alien and hostile to me on account of my ignorance?' (Ibid.)

This, the commonest of dilemmas facing the consciences of all intellectuals, led him to claim that negation was his God; and in history his heroes were all those who destroyed the old - Luther, Voltaire, the encyclopedists, the terrorists, Byron; but he had a vision of the future which excited human hearts and minds for generations to come and came to be reflected principally, in literary terms, in Dostoevskii. Out of the mouths of Versilov and Ivan Karamazov came publicly acknowledged visions of a new justice and a new paradise very similar to those Belinskii expressed privately to his friend but related very closely to the intellectual spirit of the 1840 s, as were so many of Dostoevskii's ideas:

'And there will come a time, I fervently believe there will come a time when no one will be burnt to death, no one will be beheaded, when the 
criminal will beg to be executed as an act of mercy and salvation and he won't be, but life will be his execution as death is now; when there will be no senseless forms and rituals, no impositions and conditions imposed on feelings, no duties, no obligations, and one person's will will not accede to another's will but only to love; when there will be no husbands and wives but simply male and female lovers... Women will not be the slaves of men and society, but, like men, will be able to satisfy their inclinations freely without losing their reputations... There will be no rich, no poor, no kings and their subjects, just brothers, just people, and in the words of the Apostle Paul, Christ will give His authority to the Father, and the Father - Reason - will reign once more, but in a new heaven and a new earth... I yearn for a golden age, not the former, senseless, bestial golden age, but one conditioned by society, by laws, by marriage, by everything necessary in its time and not the stupid, vulgar way things are now.' (XII, 70-1)

Here were Utopian Socialism, free love, female emancipation, SaintSimon, George Sand and many other influences mixed into a deeply humanistic, neo-Christian and very personal confession of faith which required him, as Belinskii admitted at the end of 1841 (letter to N.A. Bakunin of 9 December), to be 'a fighter in this world... And because of this a dozen people sincerely love me and a hundred hate me.' (XII, 76)

By this time he recognised that he did not belong to those of a purely inner nature: 'I am as little subjective as objective by nature, I am on the border between these two great worlds.' (Ibid.) Evidence in support of Belinskii's growing concern with politics is supplied by I.I. Panaev's memoirs. The latter, excited by recent French re-assessments of the French Revolution and new developments in Utopian Socialism, organised discussion evenings at his home. Belinskii probably attended them on a fairly regular basis during the winter of 1842-3, and possibly earlier. ${ }^{2}$

Throughout the remaining years of the 1840s he sought to express what he thought of as his socialist sympathies as fully as possible. There were always, of course, the constraints of censorship and the equally constraining effect of editorial policy, not to speak of the state of his own health. Less easy to define was the constraint inherent in his own commitment to this new ideology. It was as much subjective as objective and as much emotional in its philanthropy as it was high-minded in its concern for the social role of literature.

2 The direct evidence for this is contained in Pt. II, Ch. VII of I.I. Panaev, Literaturnye vospominaniia, Gos. izd. khud. lit., 1950. The matter is discussed at length in Ch. II of V.S. Nechaeva's V.G. Belinskii: zhizn' i tvorchestvo 1841-48, izd. 'Nauka', 1967. 
Not surprisingly, in 1841-2, he devoted much of his writing to theoretical issues. He sought to understand what literature was in the light of this new ideology, its function in Russian society and its role as an essential aid in defining nationality or national spirit (narodnost'). One of the most interesting examples of this endeavour was never published in his lifetime but was very likely written in 1841: 'The General Meaning of the Word Literature, ${ }^{3}$ and was supposedly intended to form part of a larger 'critical history' of Russian literature.

It emphasised at the outset the need for literature to be organic because such organic consistency in growth could only be produced by a national literature within the context of world literature. But literature did not strictly speaking have a nation as its hero, it had individuals, and relied on public opinion, on society, for its existence, because 'society finds in literature its real life raised to an ideal, brought to consciousness.' (V, 625) This ideal, for Belinskii, was the unity exemplified by the life and culture of classical Greece, a unity being re-achieved in an increasing internationalism caused by the spread of the printed word. The vision he then offered chimed in well with his newly discovered Utopian Socialist and Francophile sympathies, for France struck him as being the new Greece:

'... a Greece which has passed through Christianity, has conquered the climate, nature, space and time and entirely subjugated to its spirit the kingdom of matter; in the new society beliefs and creeds will be the reason and knowledge of society, while knowledge will be belief, belief will be the source of vital activity and vital activity will be a manifestation of belief; and there will be a new earth and a new heaven!' $(\mathrm{V}, 630)^{4}$

Such a statement would be censorable and possibly considered blasphemous and was no doubt the reason for the non-appearance of the article in Belinskii's lifetime. It anticipated quite clearly the vision of a socialist paradise offered in Vera Pavlovna's final dream in Chernyshevskii's famous novel What is to be Done? The article in fact first saw the light of day virtually at the same time as Chernyshevskii's novel,

3 Belinskii's friend, N.K. Ketcher, is thought to have given the manuscript this particular title.

4 Quoted from Mark Poliakov, Poeziia kriticheskoi mysli, M., 1968, p. 105. It has been pointed out, particularly by Nechaeva, that another version of this passage exists. After 'kingdom of matter': the following words had been crossed out: 'The sun of reason will rise over mankind, and no one bearing the title of man will be excluded from the gifts of the universally accessible human spirit, and for all men consciousness will be life, life consciousness, thought will be action and action thought, and for all there will be a new earth and a new heaven.' V.S. Nechaeva, op. cit., p. 65. 
probably more than a couple of decades after it was written. ${ }^{5}$ It concluded with a declaration that Russian literature resulted from the westernising reforms of Peter the Great and began with slavish imitation of western forms before gradually becoming a reflection of Russian society.

These ideas were largely anticipated in the first of what became a series of annual reviews of literature which Belinskii published throughout the 1840s. 'Russian Literature in 1840' (published in Fatherland Annals early the following year) acknowledged publicly the special influence of French thought and literature, its link with Saint-Simonism via George Sand, for example, as well as somewhat speciously claiming a reconciling role for English literature in relation to its French and German counterparts. But how did Russian literature rate in this connection?

Russian literature only began with Pushkin because his poetry beat with the pulse of Russian life, Belinskii insisted. But a literature could not exist without a public, which must have a vital relationship to its writers. The writers may be the producers, the public the consumers, the writers the actors, the public the audience, but literature for the readers must be a matter of public concern, a res publica, a social matter of great importance, a source of high moral gratification and vital excitement. Yet if it were to be a reflection of the life of society, it was society that should give it life and not vice-versa. So although 1840 had seen the appearance of Lermontov's A Hero of Our Time and his poetry, Russian society was by implication not mature enough to have a literature in a precise and definitive sense. 'But we have the beginnings of a literature,' (IV, 447) the critic was prepared to concede.

Belinskii resisted every urge to make boastful claims for the literature of his native country, however earnestly he sought to discover signs of new talent. The urge to discover such new talent naturally involved him in trying to cultivate an informed and sympathetic readership capable of sharing his love of a literature directly concerned with contemporary Russian society. A high proportion of the articles written at this time had this as their aim, but with increasing emphasis given to the role of the personal and the subjective, the personality of the author or poet and the individual in society. An example was the somewhat awesomely entitled 'The Division of Poetry into Genres and Forms' (1841), in which he drew on Roetscher once more for some of the material (as well as notes by Katkov), but went far beyond classification of lyric, epic, dramatic and so

5 It was first published in the edition of Belinskii's works edited by Soldatenkov and Shchepkin in 1862, though with this passage omitted. Chernyshevskii's novel was published by mistake in 1863 . 
forth into a contrast between Hamlet and Boris Godunov. The Shakespearean hero was the source of the play's tragedy through his personal inner struggle with his conscience whereas the Pushkinian hero, clever and ambitious though he was, had no personal greatness and therefore nothing inherently tragic in his character. The tragedy sprang from the epic nature of the events surrounding him.

For all the attempts to define and categorise, Belinskii was always at his most impressive when he suddenly offered flashes of insight. 'The epic of our time is the novel,' $(\mathrm{V}, 39)$ he declared - a statement that may not seem a revelation nowadays, but was a bold claim at a time when the genre of the novel as we now know it scarcely existed in Russia. It was to this genre that he was always prepared to devote the greatest critical care as a mirror of reality. For the novel was not, of course, peopled with mythical figures. It had far greater range than the epic of antiquity. It was a product of contemporary civilisation in which 'all civil, social, family - all human relationships in general - had become endlessly complex and dramatic...' $(\mathrm{V}, 40)$ The greatest asset of the novel was the fact that it could be concerned with private life, something which could never be said of the Greek epic. And private life was highlighted above all in tragedy, in the private conflict between the natural proclivities of the heart and a sense of moral duty. Tragedy might be considered the crowning glory of dramatic poetry, but comedy, its exact opposite, if not ennobling in its treatment of the human dilemma, used humour as a reminder of what life should be like.

Another article, unpublished in Belinskii's lifetime though intended to form part of the projected 'critical history' of Russian literature, was 'The Idea of Art', noteworthy for its opening sentence: 'Art is the unpremeditated perception of truth or a thinking in images.' (IV, 585) Though unfinished, it was rich in insights, but it clearly cannot compare with his 'Speech on Criticism' as an authoritative statement of his views. The 'Speech on Criticism,' published in three parts in Fatherland Annals during 1842, proclaimed the purposes of his work as a critic at some length. ${ }^{6}$

6 The actual speech was delivered by Professor A. Nikitenko at the university of St Petersburg in March 1842 and Belinskii's article was a riposte to the published version. The article was also clearly related to his review of 1842 entitled 'A Guide to Universal History' which spoke of 'our time' as predominantly historical and mentioned the role of satire as 'the highest judgment on a depraved society' (not unconnected, one suspects, with the appearance of Dead Souls) and went on to make a close association between philosophy and history. The essence of history and its purpose, the review claimed, was to present humanity as an individual, as a personality, in order to be the biography of this ideal personality. 
Belinskii acknowledged that a spirit of analysis and criticism characterised the age in which he lived, subjecting everything to scrutiny in a quasi-nihilist sense yet thirsting for convictions and hungering after truth. Reality was the slogan of the times for a world no longer content with the multicoloured kaleidoscope of the imagination but in need of reason's telescope and microscope to bring distance closer and make visible the invisible. The act of criticism therefore meant seeking and finding in the particular the general laws of reason by and through which the particular could be said to exist and defining the degree to which the particular existed in a vital, organic relationship to its ideal.

Criticism must be judgmental, as must art, since the art of 'our time' must involve a criticism of society: 'For our time a work of art is dead if it describes life simply in order to describe life, without any powerful subjective impulse grounded in the prevailing thought of the epoch, if it is not a howl of suffering or a dithyramb of excitement, if it is not a question or the answer to a question.' (VI, 271) Even so, a line was to be drawn between conscious and unconscious art in which the human personality might only demonstrate its real independence through acting irrationally, though in so doing it repudiated the divine source containing its life and strength. Elegance and beauty were not the sum total of art (although Belinskii acknowledged he had once believed this), but beauty for beauty's sake, the self-serving function of art, was the initial stage in a process of understanding which had to accept that all living things grew and developed, meaning that art was not to be defined in terms of an algebraic formula.

It was axiomatic that beauty was an essential condition of art, just as it was an essential condition for ideas, with the consequence that it was not the beauty in empirical reality and its representation or copying in art after which the human spirit yearned but the beauty of an ideal world, a world of the immaterial, of the reason. Consequently, beauty was the daughter of reason as Aphrodite was the daughter of Zeus. Christianity had struck a decisive blow against the unconditional deification of beauty for beauty's sake and 'our time' had repudiated it for good - in the shape, that is, of Byron, Schiller and Goethe, whom Belinskii labelled 'philosophers and critics in poetic form.' (VI, 278) ${ }^{7}$ The greatest of creative talents would therefore only be short-lived if it limited itself to 'birdsong' and created

7 Walter Scott and especially Fenimore Cooper were also quoted as 'poets' imbued with historical and philosophical respect for contemporary society, for its evolution and the individual's relationship to it. 
its own world unrelated to the historical and philosophical reality of its time.

Art was subordinate to the process of historical growth and the art of 'our time' was an expression, or realisation in artistic form, of contemporary consciousness. This was Belinskii's profession de foi. As for criticism, its primary function was to define the degree of aesthetic worth of a work in relation to its epoch, its historical present and the artist's relationship to society. Freedom of creativity, the critic argued, could easily be made compatible with service of the present day. It was only necessary for the creative artist to be a citizen, a son of his society and his epoch.

So far as Russian literature was concerned, it was the product of the Petrine reforms and owed its beginnings and growth to European influences. Russian criticism had similarly to stop being an echo of prevailing European opinions and to strive gradually to reach its own original view of art.

If these constituted, in a broad sense, the basis of Belinskii's views, then they have had to be extrapolated from his often discursive and somewhat cumbersome manner of exposition. Nevertheless, they were novel, assertive and radical for their time and boldly polemical in a Russian context. If he did not always demonstrate them consistently in his criticism, he was always passionate in defending them against enemies; and his main enemies in this respect were the Slavophiles who, in their hostility to the Petrine reforms, were hostile to European influences and a literature celebrating the inadequacies of contemporary Russian society.

The polemic with the Slavophiles was, for Belinskii, as much intuitive as ideological. The most wicked of his attacks on this Moscow-based doctrine and the journal The Muscovite (Moskvitianin), the mouthpiece of Slavophilism in the 1840 s, was a short satirical pamphlet 'The Pedant', published in Fatherland Annals in 1842. It aimed to characterise the type of pedant who believed that literature should 'sugar the pill', moralise and idealise. Belinskii named him Mr Potato (Kartofelin), described his appearance and upbringing and finally excoriated him as the epitome of puffed-up ambition, a literary cynic, a rubbish merchant turned scholar, a speculator ready to convince all-comers he was the soul of honesty, and so on, and so forth. The pamphlet was signed Peter Bulldog and was doggedly plodding in its satire, with rather more bark than bite. It demonstrated what Turgenev claimed for Belinskii: 'he was a good hater'8 and with good reason, since the Moscow professors who gave rise to the

8 I.S. Turgenev, Vosp. sov., p. 509. The words quoted were in English in the original. 
pamphlet had accused him in so many words of committing a crime against the greatness of the Russian people (lèse-nation).$^{9}$ Belinskii did not permit anyone to impugn his patriotism in that respect. 'The Pedant' also demonstrated the extent to which he was prepared to fight for his cause.

This satirical article was the consequence of a short visit he paid to Moscow at the turn of the year 1841-2. It was his first visit since leaving in 1839 and it gave him the opportunity to renew old friendships, if not exactly to settle old scores. There can be little doubt that his hostility to Moscow as a place, as an alma mater and as the home of Slavophilism was due partly to a nagging sense of hurt at the way it had rejected him as a student, impoverished him and no doubt helped to aggravate his tuberculosis.

En route from St Petersburg in Botkin's company he had visited Novgorod at the very moment Herzen was attending the funeral of a newborn baby daughter. Whether or not he actually met Herzen and had the chance to talk is unclear. What is clear is that, on reaching Moscow, he met Gogol, despite the hostility of acquaintances, and apparently agreed to take the manuscript of Dead Souls (Part I) back with him to St Petersburg in the hope of arranging its publication there after it had encountered censorhip difficulties in Moscow. ${ }^{10} \mathrm{He}$ did not succeed in this and was forced to write a letter of 20 April 1842 apologising for his failure. But there can be little doubt that he must have acquainted himself with the contents of the manuscript and been reassured by the work itself that his love for Gogol as Russia's greatest writer was not misplaced.

The real reason for his visit to Moscow was personal, it seems, and involved the renewal of another relationship. In his second annual review of literature 'Russian Literature in 1841', published early in 1842, he explored the genesis of Russian literature more fully than ever before and in a more personal way, due to the dialogue form in which the review was

9 One of the professors in question was S.P. Shevyrev (1806-64) whom Belinskii had earlier attacked for his critical attitude to Gogol's Mirgorod. Another, who seems to have taken it less personally, was the co-editor of The Muscovite, M.P. Pogodin (1800-75)

10 The Moscow censors had objected to the title Dead Souls on the grounds that the soul was immortal. A change of title to Chichikov's Travels, or Dead Souls accompanied by the subtitle $A$ Poem, finally persuaded the Moscow censors to allow the publication of Gogol's masterpiece. 
couched. ${ }^{11}$ Here he appeared to speak very personally when he claimed that Russian poetry began with Derzhavin and that as a boy he knew the poet's work by heart. It had been hard for him to move from Derzhavin's 'intensely solemn' poetry to the world of Pushkin's poetry that was so 'bright, clear, limpid, so definite and loftily free, unstrained, full of content...' (V, 535) and so appreciated by women.

The mention of women's role in the appreciation of Pushkin may well have been the subtext for the Moscow visit. The relationship he sought to renew during the visit, so far as one can judge, was with Marie Orlova, whom he had known since the mid-1830s and who was to become his wife at the end of the following year. Poetry seemed the natural vehicle of romance and a means of equating the sexes, in Belinskii's view, because his claim that women particularly appreciated Pushkin developed into a candid panegyric about women's equal rights and their talent for appreciating the higher spiritual things of life as the equals of men. Women's moral development had been handicapped by crude, muscular male chauvinism, a semi-barbaric, rather eastern social structure and the sugary, arcadian type of education thought fit for them.

The idea of female emancipation, of female equality, was implicit in what he then had to say about Romanticism. It first became evident in Russian literature with Zhukovskii and his translations from German and English. 'The development of Romantic elements is the first condition of our humanity' $(\mathrm{V}, 548)$ were the words used to summarise the debt owed to Zhukovskii, but Romanticism itself received the following definition:

'Romanticism is the world of the inner person, the world of the soul and the heart, the world of sensations and beliefs, the world of striving towards the eternal, the world of mysterious visions and concepts, the world of ethereal ideas... The soil of Romanticism is not history, not real life, not nature and not the external world but the mysterious laboratory in the human heart where all sensations and feelings grow unseen, where questions ceaselessly arise about the world and eternity, about death and immortality, about the fate of the individual, about the secrets of love and bliss and suffering...' (Ibid.)

It was the world, in short, of the Middle Ages which the nineteenth century had reconciled with history and practical activity. In this context

11 Herzen commented on the dialogue format in which Belinskii assumed a hectoring, pedagogic tone towards his interlocutor: 'All right, it's clear you're very clever, but whatever made you want to waste your time with such an idiot?' The anecdote came from both Herzen and Dostoevskii. Belinskii was immensely tickled. See Vosp. sov., p. 272. Also F.M. Dostoevskii, Pss., Vol. 21, Leningrad, 1980, p. 8. 
Pushkin was initially described as a 'Romantic'. He had introduced a reform in Russian poetry distinguished by the artistry of his verse, by a vital, organic correspondence between content and form which made him the equal of his European counterparts in form if not in content, since form belonged to the poet, content to history and the reality of his people. Russian society was as yet immature: Pushkin and Gogol may have been the capital assets of Russian literature, but a literature involved a national awareness, an expression of the inner spiritual interests of society, and in this respect Russia was far from very rich.

It was a personal as well as a public statement of Belinskii's views and an initial attempt at writing a history of Russian literature as well as an annual review. The personal aspect of it was closely connected both with his anti-Slavophile sympathies and with his growing fondness for Marie Orlova, the first extant letter to whom dated from 4 March 1842 (probably in error; 4 April was more likely).

The letter accompanied a gift of Lermontov's narrative poem The Demon which was to be conveyed to her by Botkin. Hardly a love letter, it was couched in politely formal, slightly ironic terms that urged her to receive Botkin 'if only to let me know and reassure me that my forwardness has not exceeded your indulgence if you do not wish to let me know this directly and in that way give the gift of a happy day to someone who has all too few happy days.' It was signed 'V. Belinskii'. (XII, 93) A letter to Botkin of 31 March 1842 referred to her somewhat bluntly as the 'person' (sub'ekt, XII, 91) who had seemingly made his heart beat faster and was probably not indifferent to him, but it was a letter spotted with allusions to past depravities (with accompanying deletions) and it has to be supposed in any case that Belinskii could not contemplate marriage at that time for financial reasons if for no other. He was still too preoccupied with being 'Peter Bulldog', as he signed himself to his friend, accompanied by the promise to send him an uncensored copy of 'The Pedant'.

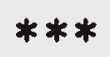

The dominant literary event of 1842 was the publication of Gogol's masterpiece Dead Souls. Belinskii saw it precisely in the light of its title. April 1842 confronted him with death in several forms. Kraevskii's wife had died earlier in the month at the age of 25 and he was provoked into thinking about death (letter to Botkin, 13 April): 'Does not our life hang suspended by a hair every hour of the day and depend on airy nothings? Why do we grieve over the loss of a dear one as if the world should have 
turned back on its axis rather than deprive us of that person?' (XII, 97) Other deaths he then recalled were those of Stankevich and Lermontov (who had died in a duel the previous year) and Pushkin. 'I consider them personal losses,' he wrote, 'and within me there is an unceasing out-oftune, drily grating sound which leaves me in no doubt they are losses personal to me, after which life for me has lost much of its meaning.' (XII, 98) It was in this frame of mind that he wrote to Gogol on 20 April. Regretting Gogol's association with The Muscovite rather than Fatherland Annals in tones which might be construed as harsh, Belinskii confessed, in the light of recent deaths, that Gogol was "now the only one left among us - both my moral existence and my love of art are closely bound up with your fate; if it were not for you, I would say goodbye to the present and future of the artistic life of our country. I would have to live solely in the past, and indifferent to the petty concerns of the present day I would take a sad delight in conversing with the great shades by re-reading their works, of which every letter has long been familiar to me.' (XII, 109)

He wrote, of course, in the light of the fictitious deaths of the innumerable named and anonymous serfs who formed the sinister background and sombre pretext of Gogol's Dead Souls. The novel's appearance in May 1842 provoked the most glowing tribute to a literary work Belinskii ever wrote. Through the subtext of his praise and the interstices of his grandiloquence, as it were, the true meaning of the work can be glimpsed:

'And suddenly amid this triumph of the trivial, the mediocre, the valueless, the talentless, amid these barren flowers and literary rain bubbles, amid these boyish pranks, childish ideas, false emotions, amid the pharisaical patriotism and pretence of popular feeling - suddenly, like a refreshing flash of lightning amid oppressive and noisome heat and drought, there appears a work that is purely Russian, national, taken from the heart of popular life, as truthful as it is patriotic, which mercilessly rips the covers from reality and throbs with a passionate, neural, consanguineous love for the fertile seed of Russian life; a work boundlessly artistic in concept and execution, in the characters of its heroes and the details of Russian conditions, and at the same time profound in its ideas, a work social, communal and historical.' (VI, 217)

No reader was more finely attuned to the novel's deeper meaning than Belinskii and as ready to perceive in it what Gogol himself, judging from his extant statements of intention, failed to acknowledge. Dead Souls (Part I) was therefore to be seen as an exposure of serfdom, the basically unjust, economically backward, semi-feudal system on which the whole 
hierarchical structure of society and government in Russia was based. If Gogol mocked it, he did so for justifiable moral and personal reasons; he did not carry the implication to the point of suggesting, let alone revealing, the political edge to this satire of a corrupt serf-owning nobility. Belinskii underscored the implication by emphasising in his review the 'subjectivity' of Gogol, a subjectivity 'which does not allow him to be apathetically and indifferently alien to the world he depicts but forces him to transmit through his own living soul the phenomena of the external world and thereby breathe a living soul into them...' (VI, 218) And in a further defence of his interpretation, in reply to Konstantin Aksakov's exaggerated claims for Gogol as a latterday Homer and his novel as a new form of epic, ${ }^{12}$ he insisted that the writer owed more to Walter Scott than to Homer and was more important than Pushkin because he was 'more of a social poet, consequently he was more in the spirit of the times... and better able to make the presence of his own subjective presence felt, which must be the sunshine illuminating the creations of a poet of our time.' (VI, 259)

The term 'poet' was used here to designate a writer who, in Gogol's case, subtitled his work $A$ Poem, but the thrust of Belinskii's claims was clear: Gogol's masterpiece signalled a coming of age for Russian literature in that it had begun to measure up to the standards prevailing in European literatures, particularly French and English. In the light of later knowledge, they were claims based on mistaken assumptions. Belinskii was too ready to ascribe to Gogol his own sympathies, his own concern with literature as a mirror of social ills in a programmatic and prescriptive sense. He praised Gogol's 'subjectivity' on these grounds but overlooked or did not want to discern the extremely personal, confessional, introspective and psychiatrically disturbed 'subjectivity' of the Gogol who sought only self-improvement and the opportunity to utter a messianic 'new word' to Russia. Belinskii did not detect any aspiration to sainthood in Chichikov's purchase of dead souls.

He never wrote a full appreciation of Dead Souls and to that extent never understood Gogol fully. He only appreciated what he saw, which was a work 'boundlessly artistic in concept and execution' that was like 'a refreshing flash of lightning amid oppressive and noisome heat and drought.' It was 'a work social, communal and historical' and

12 Konstantin Aksakov's pamphlet 'A few words about Gogol's Poem...' became a significant item in the extended polemic between Belinskii and the Slavophiles over the importance of Gogol's place in Russian literature. 
manifestly different in its concern with the reality of Russian life from the mass of trivia to which he was forced to give short notices in Kraevskii's journal.

By contrast the only literary figures given extended reviews in 1842 were poets and none received the praise accorded to Gogol. The youngest was Apollon Maikov (1821-97), whose anthological poems in classical style were considered by Belinskii to be the 'pearl' of his achievement. Another type of poem in a more contemporary idiom was less highly praised and caused Belinskii to use his pedagogic blue pencil to suggest changes which the poet later adopted. What he lacked, in Belinskii's judgment, was a true sense of tragedy as Attic drama, particularly Sophocles, had bequeathed it and the potential for tragedy implicit in human frailty. More apposite in this respect was Polezhaev's poetry. Aleksandr Polezhaev (1804/5-38), the illegitimate son of a wealthy landowner, proved to be exceedingly clever but injudicious, incurred the disfavour of the tsar and was forced into compulsory military service in the ranks where, despite two years of relative ease (1833-4), he suffered humiliation, brutal punishment and death from tuberculosis in the appalling conditions of a military hospital. Belinskii, possibly unaware of the full horror of the poet's army life, blamed the man himself for his fate but made immediate amends by emphasising his social and historical importance and commending his work both as a poetic confession of his senseless life of suffering and a celebration of freedom. The poet's severest handicap was an excess of strength in his fiery nature which made him revere an even more terrible idol, as Belinskii put it: excessive sentiment (chuvstvennost'). This meant that Polezhaev's poetry was distinguished by unusual strength of feeling while being deficient in actual content. The same reliance on feeling was the bane of Evgenii Baratynskii (1800-44), whose poetry Belinskii respected for its elegiac qualities, its sonority and evident strengths, but whose resistance to ideas and failure to develop he deplored. He was therefore demoted to second rank as a notable poet of the 'Pushkin pleiad' who had forfeited the right to be considered up-todate.

The need for literature to be up-to-date was a dominant theme of Belinskii's review of Russian literature for 1842. 'With us,' he declared programmatically, 'social life is expressed predominantly in literature' (VI, 518) which left little room for 'kindly and innocent' Romanticism, as he called it, a Romanticism which, in its Russian context, had failed to recognise the true greatness of Byron, 'the Prometheus of our time.' (Ibid.) It had been destroyed by prose in 1829 , leaving the field clear chiefly for Gogol as Russia's leading writer, whose Dead Souls had 
been so badly misinterpreted. ${ }^{13}$ But the finality with which Belinskii seemed to dismiss Romanticism at this juncture, on the eve of the crucial year in his life, 1843, has also to be interpreted with care. Romanticism was shortly to dominate both his literary criticism and his personal life.

13 If Belinskii emphasised the social importance of the novel, the notion that Gogol's characters were little more than fools and scoundrels (the claim made by Grech), or untypical (Senkovskii's view), not to mention the yet more bizarre claim that Gogol was a latterday Homer illustrated the extent to which Dead Souls was misinterpreted. 



\section{Chapter 6}

\section{Turgenev, Love and Romanticism}

By November 1842, after a summer in which his friend Botkin had been in St Petersburg and Belinskii apparently wrote few letters, he was in a confessional, reflective mood. Reminded of Michel Bakunin, with whom he had renewed contact, he explained to his brother Nikolai, in a letter of 7 November, how he had recently changed his mind completely. 'I have long repudiated romanticism, mysticism and all "-isms", he claimed, but he was quick to clarify his meaning by adding that he could not live without beliefs, 'however pasionate and fantastic, just like a fish cannot live without water or a tree without rain. That's the reason why you saw me last year so unclear in my own mind and why we could not have an hour's serious discussion. Now I have changed again. And it's odd to think that we - Michel and I - looked for God by different routes and ended up in the same church.' (XII, 114) By which he meant that, if he had found socialism, he knew that Michel had found Left-wing Hegelianism, though he could hardly guess then that this would lead to anarchism. What Belinskii did know was that a man's convictions were paramount and this knowledge persuaded him that 'If I suffer, my suffering has become loftier and nobler because its causes are outside me, not within me. In my soul there is something without which I cannot live - a faith giving answers to all questions. Yet it's not a faith or knowledge, it's a religious consciousness and a conscious religion.' (Ibid.)

By the end of November, writing to the same correspondent after learning that Nikolai Bakunin was intending to marry, he confessed further (letter of 28 November) that, though he had known love in his youth, it had been sad and difficult and far from passionate; that God had to be part of the equation, otherwise a human being was little more than a cold corpse. 'And what is God if it is not man's idea of God? I know that in order to love a woman it is not necessary to subject her ideas to close examination, but $\mathrm{I}$, in my fanatically impatient and subjective nature, I can love a woman who has captivated me with her looks far more for her 
ideas or completely fall out of love with her for the same reason.' (XII, 119-20)

News of the death of the poet Kol'tsov naturally depressed him, which in turn led him to compare himself in caricature fashion to a Prometheus chained to a fat Fatherland Annals with Kraevskii as a bird of prey constantly pecking at him (letter of 23 February 1843 to N.A. Bakunin, referring to a letter to Michel). His arduous work as a journeyman critic had disillusioned him with 'the vulgarity and filth known as Russian literature... What is reading for me if the sight of a book is like a stick to a dog?' (XII, 134) And writing to the Bakunin sisters, whom he had last seen during a brief visit to Priamukhino early the previous year, on his return from Moscow, he described his life as 'so mundane, so dry, cold, colourless and apathetic.' (XII, 141, letter of 8 March) But the same letter emphasised that he needed love now more than ever. He knew 'the importance of the word "love"' but could 'only love on a deeply moral basis. Such love, no matter for whom, if excluding hopes and demands, does not exclude passion, at least in my case. Naturally, in regard to women, this passion is more conspicuous and out of the ordinary, but to turn it into something more serious or to be insulted by it is not to understand me at all.' (Ibid.) How guarded! one might think, except that what followed was a lengthy confessional coda devoted to his own emotional frustrations and concluding with the claim that 'I never used to be lacking in arrogance but it was paralysed by many things, particularly by my romanticism and religious respect for the so-called "inner life", that progeny of German egoism and philistinism.' (XII, 142)

The 'outer life', whether expressed in political terms in his discovery of socialism or in his personal life in the evidently pressing need to find love, still remained challenged, as it were, by the pressures of his situation. He fretted at his work, his poverty, his inability to visit the Bakunin sisters at Priamukhino and at his failure to achieve his most cherished wish, which was to write a 'critical history' of Russian literature. Yet in terms of 'outer life' as biography his meeting with Ivan Turgenev at the turn of 1842-3 proved invaluable, since the latter was to provide the most sympathetic and insightful of all the many memoirs about him. Although there was an age difference of some seven years, Belinskii appreciated Turgenev's talent - he gave a very favourable review to his narrative poem Parasha (first published in 1843) — and singled him out among his friends as someone who was unusually clever, with original opinions full of character and humour. Turgenev returned the compliment in a sense by not only providing a memoir but also one of the few valuable literary portraits of Belinskii at this time. 
His first impression on meeting him in 1842 was of his small stature, slightly bent, irregular but remarkable features and fair hair falling over his forehead, someone "with the kind of severe, restless look which one comes across so frequently in shy and lonely people...' In his Reminiscences he offered a much fuller portrait on the grounds that the Gorbunov 'official' portrait, done in 1843, was just that - too official and formal:

'He was a man of medium stature, rather unprepossessing at first glance and even ungainly and unusually thin, with a sunken chest and head thrust forward. One shoulder was conspicuously higher than the other. Anyone, let alone a doctor, would immediately have been struck by all the major signs of tuberculosis, by all the so-called habitus of this evil disease. Moreover, he was almost constantly coughing.' But what Turgenev remembered most of all were his eyes. 'Blue, with little golden sparks in the depths of the pupils, these eyes, usually half-hidden behind their lashes, would enlarge and flash when aroused; when happy their look would acquire a captivating expression of welcoming kindliness and carefree joy. Belinskii's voice was weak and rather hoarse, but pleasant; he spoke, giving breathy emphasis to words "insistently, excitedly and hurriedly." He used to laugh with all his heart, like a child. He loved walking up and down his room tapping a snuff box with the fingers of his small, elegant hands. ${ }^{3}$

It was only those who knew him personally - and there were probably only three or four such friends whom he truly loved, Turgenev being one of them - who penetrated beyond the ungainly, shy and 'furious' exterior of the public image to the sensitive and ailing human being beneath. Very few, in other words, had the chance of looking deeply into his eyes and seeing what Turgenev saw. ${ }^{4}$ His portrait of Belinskii may not have been flattering, and Belinskii himself more than once acknowledged that his looks were not his strong point; yet to know the man was to be

1 I.S. Turgenev, Vosp. sov., p. 477.

2 Turgenev here quoted from Nekrasov's poem 'In Memory of a Friend' (1853), i.e. Belinskii.

3 Vosp. sov., pp. 485-6. It has to be remembered that Turgenev probably wrote this reminiscence at least a quarter of a century after the meeting. It dates from 1869.

4 Lonely though he might have been in his personal life, Belinskii had one consolation that almost amounted to a vice: he enjoyed playing cards. His fondness for préférence, the most popular card game of the period in St Petersburg, led him to claim in a review of a book on the game that it enjoyed the same status in Russia as art had done for the Greeks and civic rights for the Romans, that science now did for the Germans, theatre, balls and masquerades for the French and parliament and the stock exchange for the English. The book in question was Nekotorye velikie i poleznye istini ob igre v preferans, compiled by P. Remizov, Sankt-Peterburg, 1843. 
deeply impressed. None, it seemed, shared his deepest secret (with the possible exception of his friend Botkin, who was in any case otherwise occupied) and so none could be sure why 'furious Vissarion' behaved as he did during the summer of 1843 , let alone why he wrote as he did.

His major critical piece of the early part of the year (of January and February, 1843) was an extended two-part review of the work of Derzhavin. He had been fond of Derzhavin, the poet of the epoch of Catherine the Great, from early boyhood. Everything about the poet, he now had to admit, was dated. He was of historic rather than artistic interest, as dead as the age of Catherine and yet as alive to a contemporary readership as Catherine's age was to 'our time'. The content of his poetry was morally sententious, expressed rhetorically, couched in the form of dissertations dominated by didactic pronouncements, offering flashes of genius mixed with incomprehensible eccentricities. The review was detailed and generously illustrated with examples of the poet's work. If it could not praise Derzhavin's artistry, it could demonstrate approvingly his mastery of the ode and those characteristics of his poetry that were truly Russian. But he remained ever and always the poet of the royal house of Russia, deserving the title of 'father of Russian poets' whose most important legacy was the influence he exercised on Pushkin.

The review of Derzhavin's work opened the way for the single most important project of Belinskii's career, begun in May 1843. This was his study of Pushkin, something he had long contemplated as part of a larger history of Russian literature and now conceived of primarily as a history of Russian poetry. From the very start one issue at least was clear. Pushkin had been an 'electric shock' to Russian society. He had provided all the evidence needed of a vital movement, an organic development, which gave Russian literature the beginnings of its history. Despite this, Belinskii was cautious enough to insist that Russian literature, especially Russian poetry, was no native-grown phenomenon. It was a transplant. 'The idea of poetry came to Russia by postbag from Europe and appeared among us as an overseas novelty,' (VII, 107) he candidly admitted. French influence in the form of rhetorical poetry had its first successful exponent in Lomonosov, followed of course by Derzhavin.

The second article devoted to the study of Pushkin was passed by the censorship in August 1843 and published in Fatherland Annals, Vol. XXX, bk. ix. In other words, it was very likely written in June and July of that year. It was about Karamzin, the growth of the Russian literary language and his 'sentimentalism'. The Belinskii who had been so keen to 
emphasise social reality ${ }^{5}$ as the content of literature in so many reviews now suddenly digressed from his main thesis by embarking on a lengthy re-examination of the whole issue of Romanticism (virtually dismissed in the annual review of 1842). The reason for this re-examination can be explained more easily by reference to his personal feelings than by the historical subject-matter, the actual literature under review, just as the much more extensive and sympathetic definition of the subject can probably be attributed to an extreme change of heart:

'Romanticism appertains not only to art, not only to poetry: its source is the same as the source of art and poetry - life. Where life is, there is humanity, and where humanity is, there is Romanticism. In its most precise meaning, in essence, Romanticism is merely the inner world of man, the innermost life of his heart. The mysterious source of Romanticism is in the breast and heart of man; feelings and love are how it manifests itself, where it is active, and therefore practically every man is a Romantic...' (VII, 145)

Romanticism, therefore, and the 'inner life' virtually become synonymous, but Belinskii now carried the definition much further into a discussion of love and literature. Love had been treated in art and literature through different phases, from emphasis on love as sensuality in Eastern art to the embodiment of the idea of beauty in Hellenic art and something supremely Romantic in the Middle Ages. The Middle Ages had been characterised by extremes in a world governed not by reason but by the heart and the imagination, where madness comprised the supreme wisdom, death was life and life death, and all existence was divided into a despised here and now and an undefined, mysterious otherness. Love for woman in the Middle Ages was the very air people breathed; woman was the queen of this Romantic world. A man would regard a woman as an ideal being, any sensual feeling for whom would be considered a profanation and a sin. His thinking about her would give him courage and strength. He would call on her name in battle and die with it on his lips. There was no need for marriage in the Middle Ages; indeed, marriage was considered the graveyard of love and happiness. ${ }^{6}$

5 The term 'social reality' is used here deliberately. Belinskii's concept of 'reality' was unclear and inconsistent. Victor Terras commended Herbert E. Bowman's study (op. cit., pp. 100-09) as an excellent presentation of the concept of reality in Belinskii, but added: 'I agree with Bowman when he says that "a systematic exposition of what Belinskii meant by 'reality' is out of the question".' (p. 101) Victor Terras, op. cit., p. 41, n.17.

6 One suspects that Belinskii emphasised this view because he shared it. Marriage as an institution was derided in his early play Dmitrii Kalinin and in his letters to his future wife he insisted more than once that marriage as an institution, especially in terms of ceremony as she wanted it, was abhorrent to him. 
The Romanticism of the Middle Ages did not die and did not disappear. It continued to rule, Belinskii insisted, in contemporary society and in its contemporary form offered an organic fulfilment. Like the sun's rays in the lens of a magnifying glass, Romanticism now encapsulated within it all its different phases throughout the history of humanity. 'Our time,' so claimed Belinskii magniloquently, 'is an epoch of harmonious balance between all sides of the human spirit. The human spirit has innumerable sides to it, but only two principal ones: the inner, emotional side belonging to the heart - in a word, the romantic, and the side of the selfconscious reason, the side of the general, meaning all those interests that transcend individuality and the individual personality. In harmony, that is in the mutual interpenetration of these two sides of the spirit, lies the happiness of contemporary man.' (VII, 158) Life, we are then reminded, cannot be based on love alone, although it provided the poetry and sunshine of life, because man must relate to the real world and accept his civic duty as a citizen and son of his country. Scientific knowledge, art and civic activity comprised for contemporary man the aspect of life that should be linked vitally and organically with his romantic or inner emotional side, but should not pre-empt it.

The high-flown tone of these paragraphs can easily suggest that Belinskii may indeed have intended them for some loving and admiring listener. A clear personal note can be discerned. ${ }^{7}$ He addressed the subject of the relationship between the sexes by asserting that social activity had become essential for both sexes and in this connection, however condescendingly, demonstrated as explicitly as anywhere in his published writings his belief in female equality. It was the prerequisite for appreciating human dignity since 'mutual respect for each other's human dignity

7 Coyly and somewhat obliquely commentators during the Soviet period mentioned the connection between this digression on love and womanhood in Belinskii's study of Pushkin and the circumstances in which it may have been written. M. Poliakov, for instance, wrote: 'It was not accidental that he included an extensive passage about rational marriage in his second Pushkin article, it was not accidental that he wrote to his fiancee that he hated hypocritical marriage...' (Vissarion Belinskii, M., 1960, p. 407) But Poliakov made no effort to enlarge upon Belinskii's personal concerns at this time, no more than did V.S. Nechaeva in the final volume of her definitive 4-volume study when she skated over the issue by claiming that 'The analysis of Romanticism was not for Belinskii merely the analysis of a literary tendency, it was also propaganda and struggle for the social direction to be taken by contemporary literature.' (V.G. Belinskii: zhizn' $i$ tvorchestvo 1841-1848, izd. 'Nauka', 1967, p. 199) 
produces equality and equality leads to freedom in relations with each other.' (VII, 160)

If, as Belinskii then insisted, all human beings of differing ages experienced differing forms of love, then they also evolved in their feelings through different phases, but femal beauty was throughout the principal concern and remained one of the conditions that enhanced the dignity of women. The idea of beauty in 'our time' sought in a woman's face a certain expression of character, of thoughtfulness and signs of spiritual awareness. So that a propensity to seek the moral side of a human being, or perhaps several moral sides, and to know how to understand them and appreciate them, was the ideal of rational, as distinct from imaginary, love in 'our time'. Beauty heightened the moral qualities, but without them beauty existed only in the eyes, not in the heart and soul.

What, then, should be the moral qualities of a woman in 'our time'? Belinskii asked. He had a ready answer: a passionate nature and an elevatedly simple mind (vozvyshenno-prostoi um). A passionate nature presupposed a lively sympathy for everything contributing to the moral existence of humanity; an elevatedly simple mind involved an unsophisticated understanding of even elevated matters, a feeling for reality, the courage not to be frightened of truth unembellished by the imagination. So we arrive at the ultimate question. What, then, Belinskii inquired, was the bliss (blazhenstvo) of love?

'The likely happiness of love in our time involves a capacity for appreciating a human being endowed with a noble soul who, having heartfelt sympathy for you, can understand you as you are (no better, no worse), just as you can understand that human being and understand the attributes of moral being in that person. To look upon and respect a woman as a human being is not only a necessity, it is the principal condition for the likelihood of love for a decent man in our time. Our love is simpler, more natural and also more spiritual and moral than the love of all preceding epochs in the evolution of humanity...

'...for us the moral purity and innocence of womanhood is to be found in her heart, the fullness of her love, in her mind replete with uplifting ideas... The ideal of our time is a woman who lives not in the world of dreams but who lives out the life of her heart in reality, not a woman who feels one thing and does something else...' (VII, 163-4)

Belinskii's reader, confronted by such a digression on love and womanhood during a discussion of the Karamzin period of Russian literature, might well be puzzled. The same reader could appreciate what followed a short digest of European Romanticism from Schiller and Goethe to Byron, Hugo and Lamartine - and no doubt be prepared to accept that 
Russia had no Middle Ages and its literature therefore had no native-born Romanticism; and without Romanticism poetry was like a body without a soul. Again, that reader might accept Belinskii's judgment that only with Zhukovskii can Romanticism be properly identified in Russian literature, although he was no social poet. Moreover, Romanticism, now pronounced by Belinskii as being, like love, an eternal aspect of nature and the human spirit, had to be counterbalanced by social activity where thought became action and the two opposed banks of the river of life - the here and the there - merged, so his metaphor would have it, into 'a single real heaven' ( $v$ odno real'noe nebo...) of historical progress and historical immortality: 'This is the world of ceaseless work, of unending doing and achieving, a world of eternal struggle between the future and the past...' (VII, 195) All this a reader might accept as characteristic of Belinskii's gushing, somewhat undisciplined expository manner which owed not a little to the legacy of Hegel and the fact that his own Idealism, like his relationship with Michel Bakunin, had been abandoned on leaving Moscow in 1839 and been replaced by a much more sober, realistic appraisal of literature and its purpose now that he was in St Petersburg. Yet, as he stressed at the end of the second article of his Pushkin study, youthful enthusiasm was an essential condition for the moral development of humanity and, by implication, for the Russians, who never experienced a Middle Ages of their own and first encountered Romanticism in the poetry of Zhukovskii.

Apart from the obviously contentious interpretation of Romanticism and its history that Belinskii offered here, why in fact should he have written like this? Direct evidence is admittedly slim, and any evidence must be partly conjectural, but it is reasonable to assume he wrote so copiously about Romanticism and love at this time because he was himself in love. It was a secret he apparently kept from everyone. For in June 1843 he had taken leave of absence from Kraevskii's journal and been given some financial help by Herzen and Botkin, it seems, to go to Moscow. Herzen wrote in his diary on 15 May that he awaited Belinskii's arrival with impatience. Although they had not had many face-to-face meetings, he felt they understood each other and 'I love his sharp onesidedness that is always fearless and full of energy.' By the end of June, after their actual meeting (much overshadowed by Botkin's affairs), he was not disappointed: 'Belinskii has not changed by a whisker, he's eternally at extremes.' 8

Herzen was right. Belinskii was at extremes, though in this case they were emotional rather than ideological. The secret reason for his Moscow visit was his love for Marie Orlova.

8 A.I. Gertsen (Herzen), Sobr. soch. v 30 tomakh, Vol. II, M., 1954, pp. 282, 291. 


\section{Chapter 7}

\section{Love Letters to Marie}

Marie Orlova (she always used the French form of her name Mar'ia Vasil'evna Orlova (1812-90)) may have been maligned by memoirists and commentators but posterity owes her a debt of gratitude for saving Belinskii's letters even though she may have destroyed her own. ${ }^{1}$ She was not notably beautiful by conventional standards and it is doubtful whether she fully understood the originality of the man she was about to marry. It was to her credit that she was prepared to marry a man who had already convinced himself he could never be sufficiently attractive to a woman for her to want to marry him. Nor was theirs a love between young people. Both were thirtysomethings. Neither had any money. Neither enjoyed any hereditary status. Belinskii, admittedly, did eventually achieve entitlement to nobility status towards the end of his life, though he always considered himself a worker, a 'proletarian', just as Marie was also, in his description, a 'proletarian'. He fell in love with her partly for that reason.

He wooed her initially, it seems, through what he had written about Romanticism and love in the second article of his study of Pushkin. In one of his earliest letters to her (of 14 September) he asked pointedly whether she had read his article on Zhukovskii in Fatherland Annals No. 9 (i.e. directly referring to the second article of his Pushkin study) ${ }^{2}$ and went on to claim it had elicited a storm of praise. He added that he had no idea why it had turned out so well because 'I wrote it on the eve of the day I was able to go to Sokol'niki,' (XII, 181) on the eve, that is, of the first of many visits he made to the Moscow suburb where she was recuperating

1 Between 3 September and 30 October 1843 he wrote her 20 love letters extending over more than 80 pages of text in both pre-1914 and Soviet editions of his correspondence.

2 There is a further reference to his second Pushkin article in his letter of 20 September (XII, 187). 
from illness. Another reference, in a letter of 18 September, offered a glimpse of the way his joy at seeing Marie at Sokol'niki linked in with his plans for a major literary-critical work in the future. Living in Moscow, he wrote, 'and floating in spirit into empyrean heights, ${ }^{3}$ he had conceived what he called a 'ridiculous plan'. Presumably this was to complete his history of Russian literature on his return to St Petersburg, a project upon which he did not embark for many reasons, not least among them being the pressing need to write letter after letter to Marie herself.

His aim was to persuade her. The daughter of a priest, she had lost her mother early in childhood and been sent to the Moscow Alexandrovskii Institute where she, along with her sister Agrippine, entered a Frenchified atmosphere and somewhat prissily adopted French as their normal language of conversation. Marie was a good pupil and eventually became a klassnaia dama at the Institute. Belinskii had known her in the mid1830 s but infatuation with the Bakunin sisters, not to mention other clandestine relationships and, more importantly, his move to St Petersburg in 1839 , meant the relationship was not renewed until 1842 and assumed importance only after Marie herself had fallen ill in the spring of 1843 and been obliged to relinquish her place at the Institute in favour of her sister. During her recuperation she was living with relatives at Sokol'niki upon whom she was presumably dependent and to whose narrow, provincial ideas she had to defer. He had to persuade her, in the face of these relatives' objections, to leave Moscow and join him in St Petersburg where they would be married.

He himself returned to St Petersburg early in September. Lack of money and time proved the major obstacles. He could not afford to return to Moscow because his work forced him to remain in the imperial capital. In any case, he was indebted to Kraevskii for being allowed to spend time in Moscow that summer and, furthermore, he was occupying what had formerly been Kraevskii's apartment. His was a form of slavery - or esclavage, as Marie herself described her own state — and a slavery compounded by the fact that he felt obliged to send her long letters almost every other day from early September onwards in an effort to persuade her to join him. They were love letters - anecdotal, desperate, pleading, angry and enormously verbose, but they revealed the man himself as lover more candidly than any of his literary critical articles.

3 It is significant that this remark was a quotation from Gogol's An Inspector General (Revizor). The notion may well have been one of the reasons why he made such a significant reference to the role of literature as an 'inspector general' in his annual review of literature for 1843. 
By 20 September the tone of these letters was easily discernible. $\mathrm{He}$ was responding to Marie's pleas of poverty and her apparent obstinacy with some exasperation. ${ }^{4} \mathrm{He}$ wrote in reply to some description of her state which we do not know:

'So far as an old, sick, poor, ugly wife is concerned, sauvage in society [as she had apparently referred to herself] and having no idea how to run a house, which is God's punishment upon me, permit me, Marie, to inform you that you are being plain silly. I am particularly glad about the epithet "poor": in fact, you're maddening me with your poverty - I have never had any intention of marrying some kind of fat merchant's wife with black teeth and a dowry of a hundred thousand! As for you being old, I would be absolutely desperate if, in the first place, I wanted a young wife... and, secondly, if I hadn't seen and known men who suffered quite as much from the youthfulness of their wives as others suffered from their wives being old...

'... I hope we will be happy, but no decision on that question will come from hoping or foreboding or calculating, only from reality. So let's go forward without glancing over our shoulder and be prepared for whatever comes - being humanly worthy of happiness if fate gives us it and, with dignity as human beings, bearing unhappiness for which neither of us will be to blame... Every important circumstance in life is a lottery, particularly marriage; one can't stop one's hand shaking as one stretches into the mysterious urn for one's lot, but is there any need to hold back because one's hand is shaking? You're ill, it's true, but I am also ill; I would be oppressed by having a healthy wife who had no inner knowledge of the meaning of suffering, so we'll have no reason to envy each other and will be able to understand each other in everything - even in our illnesses...

'Give me your hand, my kind, dear friend, and whether leaning on it or supporting it I am ready to set out on the road of my life boldly and in hope. I believe that to feel beside my heart a heart like yours, to be loved by a soul like yours, is no kind of punishment but a reward beyond measure, beyond anything I deserve. You call yourself ugly and even surly; so what? I love your ugly face and find it beautiful - there's

4 All ensuing quotations are taken, as elsewhere, from the Soviet edition (with volume and page number in brackets) which is approximately similar to Belinskii: Pis'ma, Vol. III (1843-48) pod red. E. A. Liatskogo, Spb., 1914.

These letters have never been translated into English before, nor do they appear to have received much scholarly attention. The only reasonably detailed study of Belinskii's marriage is to be found in an addendum to V. S. Nechaeva's V.G. Belinskii: zhizn' i tvorchestvo (1842-1848), M. 1967, pp. $443-78$. 
nothing punishing about that. You're awkward in society - I am too, so we'll be all the happier in our own company. If you were sociable and loved going out, then I would really be severely punished for my sins.' (XII, 187-8)

The tone of such a confession may be loving but it can hardly be called wildly romantic. The letters that he poured out to his intended during late September and throughout October 1843 were a little stiff and formal, mostly signed ' $\mathrm{V}$. Belinskii', always veering between patience and petulance. He had hoped, of course, that marriage would have been as simple a thing for him as, on the face of it, it was for his friend V.P. Botkin and his grisette Armance.

On his return to St Petersburg in early September Belinskii had been astonished to find a young woman sitting in an armchair in his study. This had turned out to be Botkin's Armance. She had taken a great liking to Belinskii's apartment, particularly his pictures and his furnishings (modest though they were). Her verdict was 'Il $a d u$ goût'. Shortly afterwards she and Botkin were married in a simple ceremony attended only by the bridegroom's closest friends.

An ideal arrangement, so Belinskii was to insist more than once in his correspondence with Marie. But that was by no means the way the story began. According to Herzen, ${ }^{5}$ Botkin had been prevented from legalising his relationship with Armance earlier by his father's intransigence. It was therefore decided that Armance should stay with Herzen and his wife at their estate of Pokrovskoe while Botkin arranged for his marriage to be conducted by Father John, a notoriously drunken local priest. On the appointed day Herzen and his wife waited. Dinnertime passed, it struck midnight - still no Armance or Botkin. Suddenly there was the sound of an approaching carriage and Botkin jumped out. Herzen stepped forward to assist his companion, supposing it to be Armance. The person in question seized his hand so tightly he almost cried out with the pain and then proceeded to fling him- or her- self at him with laughter and cries of 'Monsieur Herstin!' It turned out not to be Armance at all but Vissarion Grigor'evich Belinskii in propria persona, as Herzen put it.

What had apparently happened was that Botkin had 'reflected', philosophically speaking, on the implacable fatalism of marriage. He had locked himself away and surrendered to a spirit of tormented research and

5 The story comes from a section of Herzen's memoirs (Past and Thoughts) entitled 'An episode from 1843' (Book IV, Ch. xxviii). Armance's surname was Rul'iar (in Russian transliteration). 
merciless analysis. His apprehensions had mounted hour by hour until there came a knock on his door in Moscow and there stood Belinskii, recently arrived from St Petersburg (presumably earlier that summer of 1843; probably 10 June, though Herzen gives no precise date: he was an unreliable memoirist in respect to dates). Belinskii suggested Herzen should be approached about the problem.

Botkin jumped at the suggestion. He wrote at once to Armance with a dissertation about marriage and his own unhappy reflections on the matter, no doubt referring to Hegel and other authorities. He ended by asking her what he should do.

Armance, of course, a simple soul, of uncomplicated plebeian background, wrote back a sad letter in which she was surprised and hurt, found his 'reflections' incomprehensible and naturally interpreted them as evidence of a cooling towards her. She said that in the circumstances there could be no talk of marriage, freed him of his obligations and declared they should not see each other any more. She concluded by writing: 'I will remember you with gratitude and will in no way blame you. I know you are extraordinarily kind, but even more extraordinarily weak! Farewell and be happy!'

Botkin apparently had a further change of heart while at Pokrovskoe, though he decided to return to Moscow after a couple of days with the intention of going abroad. A few days later Herzen visited him there and was surprised to be part of a farewell party replete with champagne and toasts which hinted at a reconciliation with Armance. This turned out to be the case. Botkin had discovered that he was deeply in love with his grisette. Since he could not arrange a marriage in Moscow, he was taking his Armance off to St Petersburg. There a ceremony was performed in Kazan Cathedral by archpriest Sidonskii, a free-thinking cleric who had written a work on the science of philosophy and knew Botkin as an irreligious Germanist of secular views. Botkin himself was now prepared to concede that Christianity possessed eternal value in its essence and substance. As for Armance, so Herzen waspishly informs us, her marriage as performed by such an archpriest was to have the rare honour of serving as the cause of one of the most comic encounters between the two implacable enemies, science and religion.

A couple of days after their marriage Belinskii saw them off from Kronstadt. Gleefully Herzen tells us that all apparently went well until they reached the Kattegat. At this point Botkin asked Armance what she thought of George Sand's novel Jacques which she had just finished reading. She expressed an opinion with which he disagreed. They entered the North Sea. The disagreement persisted. By this time, almost dying of 
sea-sickness, Armance stubbornly summoned her last resources to defy Botkin's attempts to change her mind.

'So what is there to keep us together after this?' remarked Botkin, deeply upset.

'Nothing,' answered Armance, 'et si vous me cherchez querelle it would be better if we went our separate ways as soon as we reach land.'

'That's your decision?' asked Botkin, taking umbrage. 'You'd rather...'

'Anything on earth rather than live with you! You're unbearable, a weakling and a tyrant!'

'Madame!'

'Monsieur!'

She went off to her cabin and at Le Havre was true to her word: she left Botkin. She was 18 years old. He was at least 32 .

In fact, he was Belinskii's own age and an obvious example of the dangers of marrying a young wife. Belinskii could not, of course, have known that this was to be the outcome of the Botkin-Armance romance, even though he might have guessed as much. Being in love himself, he could see the charm of Armance, her straightforwardness and honesty, and hold up such qualities as an example of true love, true self-sacrifice, to Marie in his efforts to persuade her to join him in St Petersburg.

In his letter of 14 September Vissarion had this in mind when he recalled the small ball given by M-me Charpiot, the principal of the Alexandrovskii Institute, while he was in Moscow. Other women might have been 'fresher, more elegant and prettier' than Marie, he had to admit, but she alone had:

'... facial features that were so firmly symmetrical and exuded such nobility, such dignity. Your beauty has the grandeur and elegance which are endowed by intelligence and deep feeling. You were a beauty in the full meaning of the word... What was yours was what beauty and youth might envy and can never be taken from you. I have long since begun to understand this; but experience is the best teacher, and I recently was more than ever convinced, through another's experience, that there is nothing more dangerous than linking one's fate with the fate of a woman simply because she is young and beautiful.' (XII, 180)

Though the reference could well be to the Botkin-Armance relationship, he had other things on his mind. By 18 September, a Saturday, he was feeling miserable at not hearing from Marie. Having made a bit of a fool of himself at a party the previous evening by being obliged to dance a French quadrille and muddling up the steps, he had drunk too much champagne, developed a headache and, so far as the wedding plans were 
concerned, could not escape the problem of money, let alone the equally problematical need to obtain the necessary papers from his home town of Penza. Nor could he see why Marie should not come to St Petersburg for the wedding. The thought of being wed in Moscow in the church of the Alexandrovskii Institute, in the presence of the principal M-me Charpiot, was quite abhorrent:

'I would rather get married to you in Kamchatka or the Aleutian Islands than in Moscow.' (XII, 185)

This was, of course, the nub of the issue. Marie was finding it hard to accept the likelihood of the shame or social opprobrium which might accompany any decision of hers to go to St Petersburg. The socially acceptable course would have been for him to come to her to get married rather than the reverse. The whole protracted correspondence revolved about this issue. Meanwhile, as he announced in his conclusion to his letter, he had given up taking snuff.

Two days later he offered an addendum to his letter after having received Marie's and been even more deeply dismayed by her pretentious plans for a Moscow wedding. Though loving her, and sure of her love for him, he could not avoid feeling she was being unduly influenced by her relatives, especially by her sister Agrippine. They appeared to be deliberately placing obstacles in the way of a happy outcome. Moreover, her determination [so she apparently claimed in her letter] not to write more than once a week although she had earlier promised to write more frequently left him wanting to tear her letter to shreds (which, for all we know, he might have done).

Again the Botkin-Armance romance cropped up. Marie had apparently misunderstood his reference to Armance's age. He wrote back saying that it was not a matter of age difference, so far as Botkin and Armance were concerned, 'but the bad thing is they don't understand each other and have nothing in common.' (XII, 191) By Wednesday 29 September, on re-reading what he had just written, he was expressing the fear that he had perhaps misinterpreted her attitude. He had not been well. Maybe this had been due to the fact that he was, as he put it, too 'impressionable' and his state of mind may have had an effect on his health. Still, a few friendly lines written in her hand would work wonders! Meanwhile, he had been desperately busy trying to complete his articles for the October issue of Fatherland Annals and his right hand had gone stiff as wood and was on the point of breaking.

By 1 October he was close to admitting defeat. Her letter had apparently been a crushing blow to him in every way. Apart from the fact that he could not spare the time to go to Moscow (money difficulties aside), he 
was appalled at the way she was expecting him to submit to 'comic, ignoble rituals which profane the sanctity of the relations into which you and I are prepared to enter, rituals which I despise and hate on principle and are against my very nature. A formal dinner at uncle's! To hell with all dinners, all uncles, all aunties and all government employees with their filthy rituals!' (XII, 193) Far better she should come to St Petersburg and then arm-in-arm, again like Botkin and his Armance, they should go through a simple ceremony (not, of course, such a clash between religion and science as Herzen had assumed it might be). He had no wish to go to Moscow, that égout, that sewer 'full of uncles and aunties, those social dregs, that social sediment, that fag-end of Tartar civilisation. You write that there will be twenty people present from your side at the wedding ceremony and you want 10 or 15 from my side. Where on earth will I get such a horde from? All the people I know would find such a spectacle of no interest at all. There would probably be no more than three.' (XII, 194)

Her letter then seems to have mentioned something about 'excommunication'. Unless certain ritual visits were made after the ceremony, etc., they could be 'excommunicated'. 'Marie, Marie,' he exclaimed, 'why are you going on about excommunication? Have you so little love and respect for the man you have chosen as your lifelong companion, so little respect and friendship for all those he respects and loves, that you still want to know what people might say about you, people with whom you have nothing in common, who are no more concerned with you than you are with them?...' (Ibid.) He went on to say that he could not hide from her how bitter he felt at seeing her committed to prejudices that were beneath her. He had wanted her to come to St Petersburg so as to avoid such pomp and circumstance. But he was prepared to go to Moscow provided the wedding could take place in a parish where the banns of marriage need not be read and the ceremony would be over by $4 \mathrm{p} . \mathrm{m}$. in order to catch the public stage-coach or 'diligence' leaving for St Petersburg at 6 o'clock.

Shortly on the heels of the letter of 1 October he sent another, dated 2 October. He developed his reasons for not wanting to go to Moscow, though these amounted in some respects to little more than the apprehensions of any intending bridegroom. He was sickened, he wrote, not only by the fact that she was condemning him to the shameful torture of a dinner, etc., but also that 'you are displaying such resignation in regard to your own self. For me that's more difficult than anything. You don't even want to understand the reasons for my horror and revulsion at these shameful ceremonies...' (XII, 196) She had compared him, it seems, to Gogol's Podkolesin, hero of his play The Marriage, who showed the 
utmost reluctance to get married and ended by jumping out of a window. There would be no jumping for Vissarion Belinskii, he assured her, but she appeared not to understand that he found the words fiancee, wife, bridegroom, husband distasteful and what he wanted her to be was ' $m a$ bien-aimée, amie de ma vie, ma Eugénie,' (XII, 197) ${ }^{6}$ because, to him, marriage was merely a legal formality and should be a private matter between two people.

He recognised that two things stood in the way of her coming to St Petersburg, her sister Agrippine's work and her own worries about making such a lengthy journey by public stage-coach all alone. The first could perhaps be solved by his writing an official letter, the second by his assurances that the journey would involve plenty of pauses for rest and little inconvenience. In any case, St Petersburg was a whole century in advance of Moscow in its ideas and her 'Muscovite fear of what people will say about you... is a crime against God and your conscience.' (XII, 199)

The tone now veered between the acerbic and the doting, lightened by touches of self-mocking humour. If she were to be married in St Petersburg rather than Moscow, she would be among strangers, but strangers who were friendly disposed to her. She would be free of all the uncles and aunties and all the Moscow gossips. 'Marie,' he besought her, 'I ask you yet again and implore you in the name of all you consider holy in life this cup will pass! Don't leave me to perish in the flower of my years and my beauty! I particularly regret the latter, my beauty, that is to say, because I will be a very unbeautiful sight throughout such sorrowful time as I spend in Moscow. If it can't be otherwise, so be it!...' (XII, 201) A few lines later, though, he reproached her for her coldness and for adopting such a haughty tone in her third letter to him, as if she couldn't be bothered to look at us:

'... nous autres, pauvres diables. Is that because you're a woman and have to remain true to your woman's nature? If so, that makes me feel no better, because if you're a cat (sorry: all ladies are more or less like cats), then I am a bear, or - worse - a bulldog and have no idea how to penetrate the caprices amd contradictions of the female heart... Pax, Marie, give me your hand, whose enchanting contact I can feel at this very moment, give it to me firmly, so I can hold it firmly and press it to my burning lips and the tear welling up in my eyes may fall on it. At this very moment I can see you standing in front of me, I am looking into your eyes and I am drowning in the depths of your loving gaze.' (XII, 201-2)

6 Heroine of Georges Sand's novel Horace. 
Still prepared though he was to go to Moscow if he must, a further letter of the same date made it clear he would greatly prefer her to come to St Petersburg. Yet again, an extended letter of 3-4 October pointed out that a marriage in St Petersburg would probably mean the loss of only three days' work for Kraevskii's journal while a trip to Moscow would involve as much as twenty-one days, with the inevitable likelihood that he would not be able to complete his article. This could provoke a serious cooling in the relations with his employer. What is more, a trip to Moscow in fulfilment of what he called 'Chinese and Mongolian customs' would oblige him both to play the role of an 'intended', followed by the role of 'young married man' (XII, 204) and for that purpose he would have to waste money not only on the journey but also on buying a frockcoat, a white waistcoat and a white tie. Far better if she came to St Petersburg. No money would be wasted on such frippery and, what is more, all his own friends had got married in unusual and informal ways and she did not need to feel that any scandal attached to such behaviour.

By 4 October, a Monday, he was in a quandary. The thought of the role-playing, the formalities, the submission to 'the humiliation and shame of Chinese and Tibetan customs' (XII, 207), the indignity and hypocrisy of it all if he were to go to Moscow left him in a near-hysterical condition. His reproaches, however energetically expressed and wellmeant, naturally led him to wonder whether their disagreement might lead to a postponement of their wedding until the following Lent. He ended with a further profession of love:

'Oh, Marie, Marie, it is only now I have felt how strongly and how deeply I love you. What I consider your inadequacy makes me feel not anger at you, not cold towards you, but makes me suffer for you. Ever since I received your letter I have not been myself. You recently wrote that you were old, ill and unsociable, that these were faults in you which I had to accept as punishments from God: I laughed and I still laugh although - I say this not in praise of myself - few people are capable of laughing at this sort of thing. But what I see as your greatest fault, which far too few people are capable of regarding as a fault, is your esclavage... Understand what I mean and respect in me what comprises the basis and the best side of my nature and my personality.' (XII, 208)

Suddenly, in the middle of the torrent of beseeching and reproachful letters which he sent to Marie Orlova in October 1843, he revealed himself in all his essential honesty and dignity. Nothing was closer to Belinskii's heart than his belief in freedom and his fierce opposition to slavery in so many forms - the slavery, for example, of serfdom, of 
prejudice, of submission to custom, of ignorance and absence of culture. This - the freedom of the individual in any reasonable and civilised sense - was the cornerstone of his thinking and the basis upon which he set all his hopes for what we now think of as the Russian intelligentsia. But ever-present as a threat to all his hopes, and in the end the one thing that most jeopardised them, was his personal health. By the time he received Marie's next letter he was seriously ill. On 10 October he described how he had fallen ill with a fever and felt 'a hellish fire inside me and unbearable cold outside.' (XII, 210)

$\mathrm{He}$ applied mustard poultices and sent for the doctor. The doctor ordered the application of twenty-four leeches, twelve to each ear. 'The next day, Friday, your letter found me in a most beastly state - lying on a couch, my pillow covered in dried blood, my shirt collar also, my chest all bloody, the bandages round my ears had come away and the blood had coagulated and my face was pale, unshaven and blood-spattered. In a word, not a beautiful sight, but interesting. That day I was so much better that Turgenev spent the evening with me.' (Ibid.) They talked about Byron and other important matters. Meanwhile, to Belinskii's delight, Marie had apparently agreed to his plan to come to St Petersburg and was planning to travel on 15 October, but he suggested she should leave it until 28 October. The rest of his letter of 10 October was devoted to practical matters concerning the documents she would need to have with her and her travel arrangements.

By 12 October he was expressing great satisfaction with Marie's attitude. Her letter, received a couple of days earlier, he described as 'beautiful: as in a mirror it reflected you heart and soul and everything about you that I have respected so highly and therefore loved. In that letter you were entirely yourself, without any extraneous influences.' (XII, 213) But her latest letter was another matter and it drove him into a state of frenzy.

She had been having second thoughts, it seemed, and was less inclined than ever to travel to St Petersburg. What she had written - and we can do no more than glimpse her side of the correspondence through the references or quotations which he offered - prompted the longest, most passionate, ironic and sermonising of his love letters. It is to be read as one side of an irritable exchange between lovers in which he lectured, scolded, mocked but never ceased to profess love while reproaching her for showing less love and understanding than he expected. The issue was again her esclavage.

'I am appalled by the thought that you, whom I considered the best of women, that you, in whose hands now lie the happiness and the misery of my entire life, that you, whom I love, that you should be the slave of the 
opinion of Moscow gossips, scandalmongers and old aunties. This is how God has punished me for my sins and not because you're 32 and unwell!... You have the capacity for limitless self-sacrifice, for love and devotion that are full and complete, but only on the condition that you have the permission of the government and the approval of uncle and auntie. If I were your husband and you my wife, oh, you'd gallop to the ends of the earth to be with me and be offended if someone saw anything extraordinary in this and praised you for it... You say if you'd been an orphan and completely alone you'd not have hesitated one moment about coming to St Petersburg and not been frightened at all about spending two or three days under the same roof with me before getting married. I don't believe you, Marie, I simply don't believe you. There are situations in life for which no conditions can be laid down, which don't permit of "ifs". One of them is love, particularly for a woman. It is her duty, her obligation, her religion, and for a woman there is nothing sweeter than to sacrifice everything for the religion of her heart. Love gives her the strength to do great things and strength enough to put to shame a proud, strong man.' (XII, 215-6)

The nub of their disagreement was, he supposed, that she looked upon him as her affianced, her intended, with whom she was prepared to spend the rest of her life. 'I look on our relations quite differently,' he wrote. 'In my eyes you've long been my wife, from whom there can be no thought of separation. And therefore I think that if, in marrying you, I will have the right to order you to travel five or six hundred miles to start with, why doesn't society recognise my right to do that right now!' (Ibid.)

Selfish? Egotistical? Hard for Marie to understand? One may feel sympathy for her on receiving this, immured as she doubtless was in her gossip-ridden world of Sokol'niki outside Moscow. Still, as he went on to point out, there were practical reasons which prevented him from going to Moscow - money, principally, both the cost of the journey and the fact that he had to earn a living as a workaday critic. His letter ended with a torrent of beseechings and professions of love.

'Marie, my dear, my darling Marie, I am at your feet, weeping, clinging to your knees, kissing the edge of your dress, begging you: Save me from grief and despair, make me as happy as possible - come here! But do decide on this firmly, courageously, consumed by a sense of the obligations which love imposes on you if you really do love me.' $\mathrm{He}$ dismissed as chimeras her fears - probably unjustified in any case that her father's health might be irreparably harmed if she were to go to St Petersburg. 'Oh, Marie, Marie, if only you knew how my heart aches with love for you and how I grieve for you! If only you knew how all thought 
of you has imbued my entire being! And if I sometimes speak so sharply and quarrelsomely to you, believe me, I would never have resolved to do so if the fullness and strength of my feeling for you did not give me the right. You are the dear child of my heart - and sometimes I haven't the strength not to scold you and therefore I haven't the strength not to feel sorry and not feel angry at myself. I can't do a thing for the journal because I'm all the time thinking and dreaming of you. And ill as I was, in the hell-fire of fever, I never for a moment stopped thinking about you and not about myself, but was worried how my state would affect you and took fright at it. I live your life, your grief is like a poison for my life, your death would be my death.' (XII, 218-9)

In a letter of the following day, 13 October (actually written, one suspects, the day after), he was even more passionate. The idea that she should be enslaved to the prejudices of her Moscow relatives still oppressed him deeply. For once in this one-sided correspondence we may catch a glimpse of Marie herself, seen naturally only through his loving recollection, but it has a ring of truth:

'Without you I am losing a meaning to my life and ceasing to understand why I should go on living. Your image, the sound of your voice, your gestures, all of you is all around me all the time. "Didn't you notice this?" - even now I cannot recall you saying this without my heart thumping, without feeling happy. And my memory retains many words and gestures whose meaning is obscure or trivial but which I cannot recall without the liveliest excitement. Yes, Marie, I love you. There is nothing fiery in my love for you, nothing violently passionate, but there is all that's needed for tranquil happiness and noble human (but not apathetic) contentment. It is only with you that I would be able to do what I have to do, to work and live, not without some usefulness, for myself and for society, it is only with you that the best days of my life would not be wasted in vain and I would not drown in apathy and idleness. It is only with you that I would enjoy living in my little corner, leave it unwillingly and always return to it joyfully and impatiently. But no, it's not that I love you merely, I have faith in you, and I am convinced that you must, that you cannot fail to overcome your inner enemy. You have never engaged in a struggle with life and you have never had to find practical answers to theoretical questions, and that's why you're so frightened by the questions I have called upon you to confront. No, you're not worse than I consider you, but you're merely not right in thinking that you can live in this world without a will of your own and without a struggle...' (XII, 221-2)

Would her will-power be strong enough? He reminded her later in the letter that she had earlier written 'I will come, I will certainly come, if you 
want me to!' (XII, 223) His letter was marked by continuing doubts about her firmness of will, in addition to a lecturing tone, despite the protestations of deep love, which might indeed have left her hesitant. By 15 October he was himself regretting what he referred to as 'the crude and harsh tone' of his letters. 'I am horrified by the thought,' he wrote, 'that perhaps my beastly letters have had a bad effect on your health. Oh, I'm a beast, I was born a beast and I will die a beast!' (XII, 224) He quickly went on to reassure her of his love and the first part of his letter concluded with the hope that God will preserve her while his own hopes and prayers will be as inseparable from her as his thoughts.

No sconer had he put his signature 'Yours V. Belinskii' and looked for an envelope in his desk than he received a further letter from her. This time she was apparently not coming to St Petersburg. Again he set out to persuade her. The ensuing tone could be said to be more 'beastly' than ever. Fear at the social disgrace which might accompany such a trip appeared to be the cause of her reluctance and he trotted out most of his former arguments in a hectoring diatribe against her lack of courage and independence of spirit. She had referred to him as a 'despot'. This stung him. 'It shows you still don't know me well enough,' he wrote. 'I am a fanatic, true, but least of all a despot. This is not the time and place to explain to you the difference between despotism and fanaticism, between a despot and a fanatic, and so I will say no more. If we will be united at some time or another, I hope then you will know me better and be fairer to me; but now you are judging me under the influence of the thought of making the journey to St Petersburg.' (XII, 226)

The marriage, it now seemed, would have to be postponed till April when he might find the time to go to Moscow. By the end of the letter he was resigned to this likelihood. But that evening he renewed his assault in a further long and reproachful letter in which he again blamed her for becoming so enslaved to the hidebound ideas of her Moscow relatives. If only, he pleaded with her, she had stuck to her promise in her letter of 5 October! On re-reading that letter, he could at once summon to mind 'the bright and beautiful image of the best woman I have ever met in my life, of a woman who has loved much and suffered much, but a woman with whom I have fallen in love on account of her love and her suffering, on account of her simple highmindedness, her fiery heart and her noble soul...' (XII, 230) That she should demean herself by kowtowing to popular prejudice, more especially the prejudices of her hardly incorruptible, snow-white 'uncle', a minor government employee who reputedly took bribes, was something that Belinskii naturally found hard to stomach. 
Since boyhood, he declared, he had considered it a most pleasant sacrifice to the God of truth and reason to spit in the face of social opinion whenever it was silly or demeaning or both. 'To oppose it whenever there was a chance of achieving such an aim quietly and without fuss was for me a Godsend. Why am I writing this to you? So that in your enlightened moments, when you are really yourself, you'll understand it and say: if he hadn't been that sort of man, I would have loved him more but respected him less...

'Besides, what separates us is education, not nature. I love and respect your nature, I love and respect you as a beautiful opportunity to be something beautiful...' (XII, 231) It was not her fault that she had such a Moscow background, he was ready to concede, and then devoted a lengthy paragraph to his recollections of his own Moscow friends, people characterised by what he called a 'European freedom' of thought and behaviour. They were quite unlike her uncle. He would never be able to confront him without a look of deadly hatred as someone who had dared to come between him and Marie and perhaps destroy their happiness.

He was by now reconciled to a delay in their plans. The hope, as he put it, that the angel of light might conquer the angel of darkness in her heart and bring her to St Petersburg, remained forlorn but undimmed. As for her accusation that he had been writing to her under the influence of his friends, he brushed the notion aside with a laugh. She shouldn't write under the influence of her Moscow relatives but at the dictate of her heart, he scolded in return. So far as he was concerned, he had only one friend who exerted any real influence over him and that was Botkin (who was not of course in Russia at the time). 'I respect and am very fond of my St Petersburg friends, but none of them has any influence over me. I value most of all Turgenev for his intellect, but he has no idea at present that I intend to marry.' (XII, 233) As for his employer, Kraevskii, he was ill and was in any case no party to their problem, save that due to his own illness and the time devoted to writing his love letters Belinskii had not sent a line to Fatherland Annals and October was already half over. Again he implored her: 'Oh, Marie, Marie, life is short and deceitful, seize hold of it - or you may regret it later! In China custom and propriety are rated higher than truth and happiness. Come out of China, i.e. out of Moscow, and hurry to me!' (XII, 234)

By 18 October he was still clinging to the hope that she would come to him in St Petersburg, although he could not help sensing that the effect of his previous letter might have been excessively crude. He was all the more conscious of this because he had had a dream: 
'Today I dreamed I saw you. I had gone to you in Sokol'niki one morning to have dinner with you and your reiatives. After dinner you went to your room and, out of politeness, I felt I ought to go home at once. And I walked away carrying in my hands a big book which I hadn't been able to give you. Taking a few steps from your house, I caught sight of you. You were strolling along a little path or ruelle between the fence of the next house and your own where there were some saplings growing. And I watched you from a distance with an aching heart, tortured by the thought that I hadn't been able to make any arrangement with you about when I could visit next. It was all so vivid, so real, I am now full of thoughts about Sokol'niki and I remember every detail of my visits. It was a happy time! Maybe I'll never have such a happy time again!' (XII, 235)

By 20 October he was dreaming that she had already come to St Petersburg but dreams, he suspected, meant the opposite of reality and he was prepared to contemplate the worst. Still, the weather was beautiful, the sky was clear and the sun shone and he awaited a letter from her. $\mathrm{He}$ received it later that day and therefore resumed his own letter that evening.

Again she could not come; again he could not see how he could get to Moscow before April. Yet the banns of marriage were already being called in St Petersburg and everything was ready for her arrival. 'The whole of St Petersburg knows that I am going to be married. Save me! Please come!' (XII, 237)

Two days later, however, he was fully reconciled to her not coming and had even taken the difficult step of approaching Kraevskii. The whole situation was now suddenly reversed. He would make the journey to Moscow provided he could raise the money. Heartened by her apparent assurances that he would not have to attend any idiotic ceremonies or a formal dinner at uncle's (again he expressed his loathing of the man), he was in some trepidation at the thought of being presented to Madame Charpiot. Most of all he hoped that his decision to marry in Moscow would put an end to the bad feeling and misunderstandings between them. For the time being he was contrite. 'We were both in the wrong,' he wrote. 'Believe me, I am irritable and can get mad, but I am not evil, and it is in my nature for much softness and gentleness to be concealed by a crude exterior. Your influence and power over me will be limitless. I may still be able to fight you by correspondence, but when we're face to face you'll see what a coward I am.' (XII, 239)

By 23 October he was lamenting his fatally pessimistic view of life, though still nursing a slim hope he would receive a letter from her saying 
she was prepared to come to St Petersburg. Meanwhile, he had had a return of the fever and been dosed with some 'hellish medicine' that had produced sweating, nausea and vomiting but by 25 October had had the effect of making him strong enough to write. He would also be well enough to make the journey to Moscow by the end of the week. It was then Monday.

By Wednesday, 27 October, he was writing to say that he had learned from Ketcher, ${ }^{7}$ their mutual friend, that she, Marie, was intending to travel to St Petersburg. This was news to Belinskii. It was he, so he thought, who would be travelling to Moscow. Ketcher, though, insisted that the real obstacle had been Marie's uncle and Belinskii quoted his words: "Her uncle is an inveterate bribe-taker. He has, though, a good and even human side to him. He had been ordered into retirement and that was the cause of his ill health which he had deliberately made out to be due to her stubborn insistence on going to St Petersburg."' (XII, 243)

So in the end Marie came to St Petersburg. They were married in the church of the Building Institute on Obukhov Prospect in November 1843 with Belinskii's friends, the Panaevs, as witnesses. ${ }^{8}$ Afterwards the newly-weds retired to his tiny apartment where Belinskii paced about saying he would have to give up all debauchery now he was married. A woman newly-hired as a cook meanwhile created such clouds of smoke in the kitchen he was unable to work as he had intended. She had done it on purpose, he explained, evidently finding it wrong that a husband should have to work on his wedding-day.

7 N. Kh. Ketcher (1806-86) was a doctor who achieved fame as a translator of Shakespeare and was friendly with Herzen and other members of Belinskii's circle. He was to be the editor of the first edition of Belinskii's works (1859-62).

8 The story of Belinskii's marriage is to be found in Panaeva's Memoirs, e.g. in A. I. Panaeva (Golovacheva), Vospominaniia, M. 1972, pp. 102-4; also Vosp. sov., pp. 289-91. 



\section{Chapter 8}

\section{The Role of Literature and the Study of Pushkin}

The love letters to his future wife involved an arduous effort of persuasion, cajolery and argument, not to mention a violent see-sawing between loving expectation and frenzied despair. There is equally no doubt that Belinskii found his liberalism and free-thinking sorely tested by this crisis in his life. The reference to debauchery may have been a joke - a fondness for card-playing hardly amounted to debauchery — but the gradual worsening of his health, aggravated by the strain of the lengthy correspondence, was no joke at all. He was in a state of crisis and it was not surprising that his review of Russian literature for 1843, composed shortly after his marriage, ${ }^{1}$ should open with a categorical statement that Russian literature was in a similar condition:

'Our literature is now in a state of crisis, there can be no doubt about it. There are many signs that it has finally resolved firmly either to follow a proper path and call itself a "literature" or, as Gogol's Ivan Aleksandrovich Khlestakov puts it, end its life in death (smert 'iu okonchit' zhizn' svoiu).' (VIII, 45)

The reasons offered for such a categorical claim were not exactly clear. That Russian literature had only two principal outlets - the so-called 'fat' journals Fatherland Annals and The Library for Reading - was critical, but otherwise the claims for a crisis in literature during the previous year seemed to boil down to the fact that 1843 had been a lesser year than 1842 when Dead Souls had appeared ('... it would itself make up for a whole ten years without books and would be unique even among a mass of good literary works.' (VIII, 60)) and, secondly, that Russian literature was short on literary genius. Pushkin was naturally quoted as the one exception. Russian literature as an independently identifiable phenomenon had begun with him, but Gogol was now his successor and a

1 Presumably it was composed in late November and December, 1843, since it was passed by the censor at the end of the month. 
genuinely 'national' (natsional'nyi) writer renowned for his humour and comedy.

The crisis, one has to suppose, was not so much in the literature itself as in Belinskii's vision of it. In defining its role, he carried this vision an important stage further than anything he had said publicly before. ${ }^{2}$ His argument was that providence had ordained that printing (knigopechatanie) should have a noble role; and this noble role would be achieved when literature was not a plaything with which to while away the time but something consciously aware of society, when it concerned itself not with versifying and telling fairy tales about people falling in love and marrying, but was a true mirror of society, and not only a faithful echo of social opinion but and here the crucial further stage is reached - 'its inspector general and controller (ego revizorom i kontrolerom).' (VIII, 87)

The opening sentence of the annual review had quoted Khlestakov and here Belinskii quoted Revizor as the 'inspector general' role to be played by literature in controlling social opinion. What he actually meant may be seen more clearly from the next paragraph:

'Society is not like a private person; a private person may be insulted and vilified but society is above insults and vilification. If you have depicted it untruthfully, if you have attributed to it vices and defects which are not there, so much the worse for you; no one will read you, and your works will evoke the laughter reserved for unsuccessful caricatures. To indicate the real inadequacies in society is to do it a service and means ridding it of the inadequacy. Why be angry about that? Who depicted English society in every aspect of its class system more maliciously and more caustically than Hogarth and yet England did not condemn Hogarth for lèse-nation [anti-Englishness], but has taken pride in calling him one of its favourite and most worthy sons.' (Ibid.)

In essence Belinskii never took his ideas on the social role of literature any further than this. Not, of course, that he need have been entirely serious in advancing such a programmatic view of literature's role. He wanted Marie to be his wife; he wanted Russian literature, the sole repository (as he put it in his Letter to Gogol) of life and progress, to exercise a governing, controlling role over social opinion in Russia, just as he wanted Marie to broaden her views and accept his own enlightened view

2 The review of literature for 1843 was admittedly published without any acknowledgement of authorship but Belinskii's style was signature enough. His thinking in private had always been more didactic than in his published work, though tempered by a self-deprecating humour, as, for example, in his letter to Botkin of 18-20 February 1840 when he referred to literature as 'a governess of society.' 
of their relationship. The personal and the public may clearly be seen to interpenetrate in Belinskii's thinking at this juncture as in so many others.

Central to his thinking, as the reference to Hogarth indicated, was that Russian society should measure up to European standards, just as oldfashioned Moscow should accept the westernised standards of St Petersburg, ${ }^{3}$ or Marie accept his passionate effort of persuasion; but the fanaticism of the argument may have inclined him to be despotic despite his own denials, and the despotic aspect of a literature designed to be an inspector general and controller of social opinion as well as its echo could hardly avoid the implication that such a literature might easily become an arm of goverment, like socialist realism, intended above all to promote a party line. A literature betraying such esclavage, such slavery to convention, was precisely the kind of literature Belinskii abhorred.

His review of the notoriously popular novel by Eugene Sue Les Mystères de Paris soon after its appearance in Russian translation (early in 1844) offered him the chance to clarify and expand his ideas. By any standards this was a novel designed to control social opinion and serve as its inspector general, and it did as much, as Belinskii admitted, by achieving the distinction of provoking controversy in the French palace of deputies. That the novel was then branded as immoral by the bourgeoisie served merely to enhance its success. It highlighted the tragedy of the French proletariat, supposedly equal before the law to the capitalist employer, but so economically enslaved by the latter that it was stripped of $99 \%$ of its earnings and forced into the direst poverty. The misery of the populace of Paris as a result of the revolution of 1830 exceeded the wildest imaginings. Yet, Belinskii was to insist, this state of things did not exist in Russia where the term 'to die of hunger' was simply a hyperbole and hard to imagine. ${ }^{4}$

3 His examination of the differences between the two Russian capitals was more subtle and profound than this brief reference may suggest. In his article 'Petersburg and Moscow' (1844, pub. 1845) he not only lavished praise on St Petersburg as Peter the Great's creation and the principal means of spreading European influences in Russian society, but he also criticised its pretentiousness and vulgarity. On the other hand, he condemned the provincial cosiness, the traditionalism and family-orientated character of Moscow while respectfully admitting that its best-informed citizens were superior to their Petersburg counterparts.

4 This statement was not apparently added as a sop to the censorship. Nechaeva, who clearly found difficulty in accepting that it could have been made by the Belinskii whom Soviet adulation had turned into a 'revolutionary democrat', argued that he may have meant it. He repeated the claim more or less word for word in a later letter to Botkin on visiting Dresden in 1847. See V.S Nechaeva (Vol. IV, 1967), p. 100. 
Two important points emerged from this review. Firstly, Belinskii made the telling, obliquely political point that Sue had shown in his novel how French laws ostensibly designed to aid the poor in fact led to ever greater impoverishment and misery, as a lengthy quote from the novel clearly demonstrated, and that this state of things indicted the whole French legal system and social structure. By implication, of course, such an indictment applied even more obviously to Russia despite Belinskii's earlier disclaimer. Secondly, he emphasised that money was the real villain. Its possession led to a hypocritical moralising which afflicted Sue's novel as much as it had afflicted Sue himself by turning the onetime Byronic idealist into a dyed-in-the-wool bourgeois who despised the masses for their ignorance and criminality. As for the novel itself, Belinskii condemned it as didactic and hardly more than an inept fairytale scarcely comparable with the work of Dickens. ${ }^{5}$

By the time he came to write his annual review of literature for 1844 , all mention of a crisis in Russian literature was missing. It had become 'the sole interest available to the public,' (VIII, 430) apart, that is, from card-playing. Literary criticism in Russia might be in a state of crisis, beset as it was by a Slavophile romanticism and Slavophile contributions to the literary scene such as the poetry of A.S. Khomiakov which Belinskii roundly condemned, but the reading public had become more selective and now sought from literature not entertainment so much as ideas, tendencies, opinions, truth and reflections of real life.

Obliged as he was by the journalistic nature of his work to devote most of his time to reviewing, he had little chance to expand his treatments of literary works into scholarly studies, although the longer reviews were always examples of studies in embryo. His review of the work of Krylov, the fabulist, emphasised the potentiality of meaning and reference in the ostensibly simple format of the fable itself by claiming that 'the fables of Krylov are not simply fables: they are stories, comedies, humorous sketches, wicked satires, in a word whatever you like, but not simply fables' (VIII, 573); yet Belinskii had to temper his praise in this general sense by stressing the often less than admirable aspects of Krylov's personal life and ultimate reputation. The work of Kantemir in its historical context elicited fuller praise than it had received in Belinskii's earlier references to him and amounted to the fullest treatment he ever gave to a literary figure from the eighteenth century apart from Derzhavin.

5 The Dickensian novels quoted were Nicholas Nickleby, Oliver Twist, Barnaby Rudge and The Old Curiosity Shop. 
There can be no doubt that his marriage contributed something important to his critical work. Scarcely half a dozen letters of his have survived from the years 1844 and 1845 . One can assume that he had no need to set down his thoughts in long letters to friends, especially to Botkin, as he had done previously. He could express his ideas to his wife, Marie, and to his sister-in-law Agrippine, who joined them in St Petersburg in May 1844. Though it is hard to know whether he in fact did this, there is evidence of greater appreciation of French culture and an awareness of the feminine aspects of Pushkin's achievement in his articles on the poet. They were, apart from the usual digressive tendencies, carefully pondered reflections graced by a general air of informed judgement and a sense of deriving from the secure background of marriage rather than the uncertainties of bachelorhood. He had, as Goncharov observed, two kinds of tribune - the public one of his journalism and the private or domestic one, which probably included his wife as well as his closest St Petersburg friends, where 'he not only knew but was also able to see his strength, as it were, test it, measure it, take pride in it while seeing how others enjoyed it.' Goncharov also went on to observe of him that 'in family life it would be hard to find a man who treated his wife with greater respect than he did. In all his relations with her there was what the French call déférence; this was characteristic of his relations with all other women of his acquaintance, including the wives and families of everyone in his circle.' 6

\section{$* * *$}

In the period immediately prior to his marriage and in the months immediately after it Belinskii devoted himself to his articles on Pushkin. Although they constitute his single greatest achievement as a critic of Russian literature, their worth and their influence were not always taken for granted. Of the most hostile reactions none can quite compare with the radical critic Dmitrii Pisarev's reaction in 'Pushkin and Belinskii' ${ }^{7}$ To do them justice, Belinskii's articles have to be seen partly through the prism of these often hostile, always prickly, sometimes hilarious assessments.

Dmitrii Pisarev was not gifted as a literary critic. His manner and attitude were that of the gadfly who subjected everything to a nihilistic scrutiny and used the sting of utilitarian value to draw blood from his

6 I.A. Goncharov, Vosp. sov., pp. 535, 548.

7 The issue has been examined entertainingly in J. Forsyth, 'Pisarev, Belinsky and Yevgeny Onegin,' The Slavonic and East European Review (April, 1970), pp. $163-80$. 
opponent's weakness. His attitude to Pushkin was frankly unkind; his treatment of Belinskii, his great predecessor in the history of Russian radicalism, combined reverence for his reputation with a pitying distaste for the critic's misguided aestheticism. Pisarev's gadfly sting did have a ready target in Belinskii's often overblown rhetoric. There is a clear instance of this in his treatment of a passage in the fifth article on Pushkin at the point when Belinskii suggested a comparison between the Russian poet and such illustrious predecessors as Homer, Shakespeare, Byron, Goethe and Schiller:

'What poetry it was! An antique plasticity and stern simplicity were combined in it with the charming play of romantic rhyme; all the acoustic richness, all the strength of the Russian language were in it in astonishing fullness; it was gentle, sweet and soft as the plashing of waves, thick and sticky as tar, dazzling as lightning, translucent and clear as crystal, fragrant and sweet-smelling as springtime, strong and powerful as the blow of a sword in the hands of a bogatyr.' (VII, 318)

To Pisarev, of course, this invited mocking parody. He responded with:

'One wonders why Belinskii didn't add that Pushkin's poetry was red as boiled lobster, sweet as a honeycomb, nutritious as pease potage, tasty as cooked grouse, ravishing as balsam and sharp as mustard. If poetry can be compared with waves, tar, lightning, crystal, springtime and the blow of a sword, I see no reason why it couldn't be compared with boiled lobster, pease potage, mustard and generally with every single thing existing in the earth, on the earth and under it. 8

The criticism is often justified. Belinskii's proneness to fine writing was a relatively easy target, but Pisarev's mockery, no doubt deployed for all the right radical reasons and typically fiery in its contempt, must also seem petty. It took no account of Belinskii's real achievement. His articles on Pushkin were the first sustained attempt to make a critical assessment of every aspect of the poet's work and it was an assessment related both to the previous history of Russian poetry and to European literature. Pushkin was therefore unashamedly compared to his European counter-

8 D.I. Pisarev, Izbrannye sochineniia v dvukh tomakh, Vol. II, M., 1935, p. 268. All further quotes from Pisarev will refer to this edition. His two articles under the general heading 'Pushkin $i$ Belinskii' were written approximately twenty years after Belinskii's articles on the poet and appeared in 1865 more or less simultaneously with his notorious 'Razrushenie estetiki' ('The Destruction of Esthetics'). Serious critical reaction to them has been generally sparse and somewhat coy. 
parts as the first Russian poet to enjoy a stature of genuinely international proportions.

The fourth article opened with a recapitulation in summary form of what Belinskii had written about Derzhavin, Zhukovskii and Batiushkov in his three previous articles and went on to indicate some features of their likely influence on Pushkin. ${ }^{9}$ Of Pushkin's earliest Lyceum poems it had little to say beyond describing them as transitional and emphasising the elegiac melancholy in them mitigated by a strength of spirit that allowed the sadness to resound in his poetry without 'drowning out the harmony of other sounds of the soul and permitting it to become monotonous.' (VII, 295) The poems themselves, it was claimed, differed from those of all previous poets in their 'perfection', their 'finished' form. (VII, 298)

The fifth article, composed presumably at the turn of the year 1843-4, began the study of Pushkin's work in earnest. It raised several fundamental points about the study of poetry. It asked:

'Where is one to find safe passage between the Scylla of an unsystematic approach and the Charybdis of theory? Judge a poet without any theories and your criticism will sound as arbitrary as the personal taste, the personal opinion, which is valuable for you alone and for others is no law at all; judge a poet on the basis of some theory, you will develop your theory very well probably, and it may be a very good theory, but you will not reveal your chosen poet in his true light.' (VII, 371)

Which path should criticism of 'our time' choose? Goethe posed the query as to what kind of reader he should like and Belinskii neatly used Goethe's answer to insist that there was an imperative need to study a

9 Pisarev was equally incensed by this connection and the suggestion that there was something 'organic' about the evolution. He belittled Belinskii's fondness for the term: 'I call the idea of organic development an Hegelian left-over which has got deeply lodged in Belinskii's head and which he attempts by hook or by crook to demonstrate even where it is completely inapplicable. Carried away by this idea, he sees something organic and necessary in all the poetic pranks of Batiushkov, Zhukovskii and Pushkin. He supposes that each of these gentlemen had - and fulfilled - their own particular role, their own particular mission in the history of the development of Russian poetry. At the present time [i.e. the 1860s] it goes without saying that such well-intentioned reveries seem strange and laughable. We know very well that in Batiushkov's, Zhukovskii's and Pushkin's times Russian thought was fast asleep and Russian poetry was not even a hothouse plant, but merely a cardboard decoration. We also know that all these gentlemen, to whom Belinskii assigned missions and roles, were simply quelques gentilhommes who, as Madame de Stael put it, se sont occupés de littérature en Russie just as they might s'occuper en Russie with breeding borzoi dogs, or cultivating tulips, or spitting at the ceiling.' op. cit., p. 271. 
poet and the world of his creativity in a Goethean spirit, forgetting the poet himself, oneself and all else in the world. No demands were to be made upon the poet's world, bringing no preconceived ideas to bear upon it, above all no convictions and prejudices. The creative activity of a poet was a special, unified, enclosed world dependent on its own laws, since all his varied works derived from one personality, from one single and indivisible $I$.

If one were to take this notion at its face value, of course, there would be little room left for criticism of any kind. Belinskii's argument, therefore, retreated a little from this position, or modified it, by stressing that the source of the creative activity of a poet was his spirit expressed through his personality and the deeper such personality, the greater the poet. Poets were born, in short; but their biographies were only of value if they were vitally related to their work. Belinskii's treatment of Pushkin admitted little or no biographical matter because he insisted that a poet and his works should only be studied through repeated reading and reliving of the works themselves. To re-live the works of a poet must mean to re-experience them in one's soul. Until one has been for a while under the exclusive influence of a poet - in the case of Byron, for instance, to have been Byronic - one cannot understand the poet. For art, in Belinskii's oddly Romantic concept of it at this stage in his analysis, did not admit of abstract philosophical ideas, even less of ideas per se; it admitted only poetic ideas, meaning not syllogisms, not dogma, not rules, but pathos. ${ }^{10}$

The emphasis on pathos was characteristic of Belinskii, since he relied on intuition in much of his critical approach, and pathos in his view turned the simple, mental understanding of an idea into love for that idea. It was a love full of energy and passionate striving that he chose to illustrate best on the example of Shakespeare's Romeo and Juliet and Hamlet, the pathos, that is to say, of the tragic lovers and the pathos of Hamlet's revenge on his uncle. ${ }^{11}$ Such true understanding of pathos was what Belinskii chose to use as a thread of Ariadne in tracing a way through the labyrinthine variety of Pushkin's works. He did not propose to analyse such pathos, no more than he chose to analyse poetry itself and resorted instead to unhelpful generalisations about poetry being poetry first and

10 This emphasis upon 'feeling', although Belinskii's definition of pathos is vaguer and devoid of religious intent, anticipates the basic notion of art as infection by the artist's original feeling as it is defined in L.N. Tolstoi's What is Art? (1898).

11 See the Introduction to this study for a partial translation of the passage on pathos in relation to Shakespeare. 
foremost and all poetry before Pushkin being no more than a gilded pill, a sugary-sweet medicine.

Pushkin himself, 'the first Russian poet-artist,' (VII, 316) as Belinskii described him, was gifted with an instinct for poetic feeling which was stronger than his rational, cognitive sense. In consequence, a poetry deriving from nature and life rather than books was accessible to his spirit, a poetry that was the smile of life, its bright-eyed look, not coldly beautiful as some women can be who arouse blind adulation rather than love. Hardly surprisingly, in view of his recent marriage, an imagery of female beauty sprang to mind in Belinskii's attempt to define Pushkin's muse and concluded with the assertion that it resembled that of an aristocratic girl 'in whom an alluring beauty and graceful spontaneity combined with elegance of tone and a noble simplicity,' (VII, 323) whose fine inner qualities were made even finer through a virtuoso sense of form that was second nature to her; and all this - above all the sense of form known to all European poets through their study of Greek antiquity - could only be Pushkin's through his manifold and profound artistic instinct, since he knew no Greek himself. Here Belinskii came closer to encapsulating the appeal of Pushkin's poetry than anyone before him, but two features especially attracted his attention. The first - as he went on to illustrate - was the way Pushkin used the banal six-foot iamb as if it were an expensive Paros marble to make wonderful sculptures 'visible in sound'. This, the 'acoustic wealth', (VII, 329) as he called it, was an unparalleled insight into the magic of Pushkin's poetry. A sense of measure and balance, the matching harmony of beginning and ending in his work, were attributes of perfection and entitled Pushkin to be considered an artist in his poetry. But the second claim Belinskii made for his muse has become more famous. Pushkin, he averred, was universal; he encompassed such a broad range of seasons, locales, peoples, nationalities. It was an idea, of course, developed in his eighth article on Pushkin when he claimed that Russians possessed chameleon-like qualities which made them capable of being English in England, French in France, etc., but not elaborated so forcefully as it was in Dostoevskii's famous Pushkin speech of $1880 .{ }^{12}$

Essential to the universality was the concept of nation and nationality; and Pushkin in this connection was declared to be a 'national' (VII, 332) poet (as distinct from 'national' in the sense of 'folk' poet, i.e. narodnyi), but more grandiloquently and prophetically he received the accolade, as

12 'Pushkin alone among the world's poets has the ability to reincarnate himself into another nationality.' F.M. Dostoevskii, Pss. v 30 tomakh, Vol. 26, L. 1984, pp. 145-6. 
Gogol had put it, of being 'Russian man in his development, as he will look perhaps in two hundred years time,' or as Belinskii himself asserted, since Russia was predominantly a country looking to the future, 'a citizen of the universe' (VII, 338) within his own poetic sphere and world view as an artist who saw in history and nature no more than motives for his inspiration, material for his creative work. What he celebrated in his shorter poems were primarily love and friendship, or feeling for life and nature even if it showed a preference for autumnal moods. His was a poetry, Belinskii insisted, 'devoid of the fantastic, dreamy, false and vaguely ideal; it is permeated by reality; it does not apply cosmetic parody or rouge to the face of life but shows it in its natural, true beauty; in the poetry of Pushkin we have a view of heaven, but it is always permeated by awareness of things earthly.' (VII, 339) He illustrated his point a little later by quoting from the harshly sardonic poem of 1830 'My pinkfaced critic, jocular and fat...' (Rumianyi kritik moi, nasmeshnik tolstopuzoi...) with its wretched glimpse of an impassively described rainy autumn village and a peasant carrying the coffin of a child under his arm for burial. The poet, Belinskii says, depicted nature; he did not reflect on it. "And this serves as further evidence of the fact that the pathos of his poetry was purely artistic, was art above all, and of the fact that his poetry should act powerfully on a person to educate and cultivate feeling.' (VII, 350)

Such an accomplishment made Pushkin most comparable to Goethe among the great European poets, in Belinskii's view, but he had earlier pointed especially to the poem 'The Crowd' (Chern') as Pushkin's artistic profession de foi. Although the poem appeared to celebrate the exclusivity of the poet, one who supposedly despised the masses, was unrelated to the everyday, to venal greed, to struggle, one born rather for inspiration, sweet sounds and prayers, Belinskii modified its message by stressing that the masses of the people were the true keepers of a nation's spirit and a poet whose poetry did not spring from the soil of popular life could not be considered a popular or a national poet.

Pisarev fell upon this poem and Belinskii's interpretation of it. If this was Pushkin's profession de foi, then, quoting rather arbitrarily from Belinskii's words, he declared sarcastically:

'There is always something particularly noble (oh, indeed!), something gentle, tender, fragrant and graceful in the contempt with which Pushkin addresses the mindless masses, flinging in their faces such vile swear words as day-labourer and slaves of necessity as if they were sacred oaths. No other Russian poet, not a single one, ever claimed the right to be a teacher of the young, the adult and even elderly reader as Pushkin has 
done, because no other Russian poet, not a single one, is so capable of inducing in his readers such boundless indifference to the people's sufferings, such profound contempt for honest poverty and such systematic abhorrence of useful labour as Pushkin.'13

Faced, of course, by such hammer-blows of political correctness, Belinskii's interpretation might seem to wilt. But implicit in his approach to Pushkin as a lyric poet was the suggestion that he, Belinskii, was among the very few to appreciate the poet's true greatness. Pushkin's poem 'The Poet', for example, contained what he called a 'false' (VII, 346) idea in the sense that, as a personality, Pushkin was never a nonentity; never, that is to say, 'more worthless than all the worthless children of the world' (nichtozhnee vsekh nichtozhnykh detei mira), nor did he ever court popularity in a public largely unable to appreciate him. Therefore, Belinskii highly prized his poem 'To the Poet' with its injunction not to cherish popular acclaim but rather to follow one's own path (...Dorogoiu svobodnoi/Idi, kuda vlechet tebia svobodnyi um). Aligned, as it were, with Peter the Great, Pushkin, in Belinskii's version, was anti-Slavophile yet essentially independent. In many of his shorter poems he saw a way out of the dissonances of life and reconciliation with the tragic laws of fate not in the cloudy realm of dreams, but in a self-reliant strength of the spirit. Thus, in his short review of Pushkin's lyric poetry, the critic tacitly acknowledged that his was a necessarily personal, exclusive, minority appraisal and concluded by letting Gogol have the last word:

'But, alas, it is an incontrovertible fact that the more a poet becomes a poet, the more he gives expression to feelings familiar to poets, the more obviously smaller grows the circle of people surrounding him and, finally, it becomes so small he can count on his fingers the number of those who truly appreciate him. ${ }^{14}$

$* * *$

The sixth article examined Pushkin's first longer poems - 'Ruslan and Liudmila', 'The Prisoner of the Caucasus' 'The Fountain of Bakhchisarai' and 'The Robber Brothers'. Written early in 1844, following directly on the previous article, it was less breathy, less compressed, and therefore more discursive and leisurely in its comment. Nowadays it may seem

13 D.I. Pisarev, op. cit., p. 285.

14 The passage occurs at the end of Gogol's short article 'A Few Words about Pushkin' ('Neskol'ko slov o Pushkine) dating from 1832 and published in Arabeski. See N.V. Gogol, Pss., Vol. VIII, Izd. Akad. nauk, 1952, p. 55. 
unnecessary to defend Pushkin from his detractors. Belinskii felt otherwise and was keen to urge his readers to acknowledge the originality and novelty of Pushkin's achievement even in such an unpretentiously charming work as 'Ruslan and Liudmila'. Its tone may have been jocular after its fashion, with no shred of Romanticism in it, so far as Belinskii could discern, and enlivened mostly by a child-like quality (detskost') that was both its weakness and its strength, but technically it represented an enormous step forward. Its beautiful language, its light, sonorous verse rising on occasion to true poetry, its smooth-flowing, entertaining and lively narrative were quoted as exemplary features of a work without parallel in the Russian literature of its time.

Even so, it was soon eclipsed in importance by 'The Prisoner of the Caucasus'. This poem met with universal approval on its first appearance because here, so Belinskii adduced, Pushkin was both fully himself and representative of his epoch. The poem was permeated by the 'feel' of the epoch, its pathos, though dual in character, since Pushkin appeared to have been attracted by two things simultaneously - the poetic life of the savage and free natives of the Caucasus and the elegiac ideal of a soul disillusioned by life. The first of Pushkin's essays in the type of disillusioned Byronic hero, depicted here in the shape of a Russian officer taken prisoner in the Caucasus and befriended by a local girl, the poem admittedly exhibited a youthful immaturity in its treatment both of the subject and of its Caucasian setting. The latter, seen largely through the eyes of the prisoner, received Belinskii's special commendation for being the first introduction of the area to the Russian reading public. The Caucasus became, as he put it, the cradle of Pushkin's poetry as of Lermontov's. Belinskii's interest was personal: he had been there and could measure the veracity of Pushkin's picture against his own. ${ }^{15}$ But more interesting to him than the travelogue aspect of the poem was its hero. The prisoner was a hero of his time characterised in his disillusionment by a spiritual and emotional froideur, apathy and premature ageing ${ }^{16}$ that were products of a

15 For a valuable discussion of Pushkin's knowledge of the Caucasus and the significance of 'The Prisoner of the Caucasus', see Susan Layton. op. cit., esp. pp. 41-51.

16 It is unlikely that Belinskii knew Pushkin's own - now famous - comment on his hero, in his letter to Gorchakov of October or November 1822 from Kishinev, to the effect that: 'The character of the Prisoner is unsuccessful; it shows that I am not suited to depicting heroes of romantic poems. I wanted to depict in him the indifference to life and its pleasures, the premature ageing of the soul, which have become the characteristic features of the youth of the nineteenth century.' 
society still innocent of the cares of maturity, on the cusp, as it were, of growing from boyhood into adolescence. Pushkin himself was prisoner of this transient moment, so Belinskii claimed, still a student of his craft and not yet its master.

'The Fountain of Bakhchisarai' received a warmer appraisal than Pushkin gave it. In the critic's view, the verse was better, the poetry more sumptuous, more fragrant, although it had to be admitted that this story of the savage Tartar Girei's love for the Christian girl Maria was really beyond Pushkin's reach. Belinskii identified the idea of the poem as the rebirth, if not the civilising, of a savage spirit through an ennobling feeling of love and had to acknowledge that in its heightened moments the treatment became melodramatic. For all its youthfulness and descriptive brilliance, the poem was not the turning-point in Pushkin's career that was the significant feature of his next poem 'The Gipsies'. It was manifestly better, however, than 'The Robber Brothers' about which the comments were quite dismissive.

By April 1844 he had completed his seventh article and his assessment of 'The Gipsies', 'Poltava' and 'Count Nulin'. Of these the first received the fullest treatment. Here Pushkin may have wished to create an apotheosis of Aleko, the hero who sought freedom among the gipsies, but instead he satirised him and his type, in Belinskii's view, by stressing egoism as Aleko's principal weakness and emphasising the fateful role played by his jealousy. These matters elicited a characteristic digression on the moral immaturity of jealousy, its opposition to true love and the offence it gave to human dignity, since 'one of the highest and most sacred principles of true morality is the religious respect for human dignity in every man... in a living, sympathetic awareness of one's brotherhood with all who call themselves "human".' (VII, 392) Devoid of any idea save egoism, Aleko was virtually bound to end as a murderer and outcast, but he was to be judged in the light of the poem as a whole and particularly the chorus-like judgement passed on him as a supposed representative of civilisation by the old gipsy. There was hope for Aleko, Belinskii acknowledged, in that he might rise to true humanity at the cost of his awful crime and equally awful punishment, ${ }^{17}$ but Pushkin, the poet, was greater than Pushkin, the thinker; had these two elements been more

17 Derek Offord suggests that Belinski's interpretation of Aleko's possible destiny invokes 'a major Dostoevskian theme, and indeed it is tempting to see Belinskii's excited tract on "Tsygany", with its diatribe on egoism (treated in Turgenev's Rudin) and its defence of free love (developed in Druzhinin's novella Polin'ka Saks), as itself a seminal influence on the Russian novel' Derek Offord, op. cit., p. 48. 
equally balanced in him, he might then have been equal to the greatest poets of Europe. Nevertheless, the poem was the first attempt by Pushkin to create something important and mature in terms of idea and artistic accomplishment, although Belinskii added the telling and perspicacious comment that, by comparison with Eugene Onegin, 'all the people in "The Gipsies" are idealised like those Greek sculptures whose open eyes do not shine with the light of real eyes because they have the same colour as their faces and are of marble or bronze like their faces.' (VII, 401)

'Poltava', if more accomplished than its predecessor, suffered in the critic's view from Pushkin's wish to write an epic poem. A valuable digression on the classical epic, its Renaissance equivalent in Dante's Divine Comedy and its more recent metamorphosis into Goethe's Faust, led to the conclusion that an epic should be about one significant historical event. 'Poltava' may have been about the famous battle between Peter the Great and the Swedes which led to Russian expansion along the eastern shores of the Baltic, but it was by no means the climactic event of the poem and might be said to be merely an episode in the love story of Mazepa and Maria. Thus, 'the epic poem is destroyed of its own accord!' (VII, 407) claimed Belinskii, for as a poem without a true hero it uneasily mixed the epic and the romantic and was outstanding in each of its parts without being an architectural whole. Yet it was in "Poltava" that Pushkin's verse achieved for the first time its fullest development, became fully Pushkinian, as it were, and demonstrated its power both in describing Peter the Great's appearance at the battle and in portraying Maria and her 'passionate and grandiose love' for Mazepa. 'Here,' Belinskii wrote, 'Pushkin as a poet rose to heights only accessible to artists of the first rank of greatness,' (VII, 421) praise which may seem inordinate by any standards but which must be considered in keeping with his generally high estimate of the female portraiture in Pushkin. His appraisal of Maria was not only deeply felt, as if it were a stage in Belinskii's own process of learning about women in the early months of marriage, but also consistent with the assumption that her portrayal had Shakespearean parallels and needed to be viewed as leading to the portrait of Tatiana in Eugene Onegin. Not surprisingly, in illustrating the light-hearted, parodistic, Flemish-interior manner of the short poem 'Count Nulin', he chose as an example the lively thumbnail sketch of the servant-girl Parasha.

Articles eight and nine, composed over the summer of 1844 and the winter of 1845 , were devoted to Eugene Onegin and have naturally come 
to be regarded as the most important and most often quoted sections of Belinskii's study of Pushkin. In fact, they tended to be more digressive, less clearly focused and in some ways less perceptive than his previous articles. Despite this, they contained memorable, slogan-like statements which have acquired lasting authority in determining the work's meaning.

He approached the meaning of the work through its creator. Nowhere was the personality of Pushkin reflected more clearly than in Onegin. Belinskii especially emphasised the historical significance of the novelin-verse and its distinction as the first work of its kind to concern itself with Russian society since 'Pushkin appears in it not simply as a poet but also as the representative of a newly aroused social self-awareness...' (VII, 432) The poet's great service had been to choose a Byronic model for his novel-in-verse and to be true to his own reality in creating an original work which, along with Griboedov's Woe from Wit, was 'the first instance of poetic depiction of Russian society' (Ibid.) and became the basis for the subsequent work of Lermontov and Gogol.

It is striking that when Belinskii came to describe the work's content he concentrated so much on the role played by Tatiana. He went so far as to claim that the novel had two heroes, as he put it, representative just as much of Pushkin's own class as of both sexes in Russian society. Pushkin's class, that of the serf-owning nobility, was basically what was meant by 'society' in Pushkin's time and he depicted his hero, Onegin, as 'a high-society figure' (svetskii chelovek). Belinskii applauded this. High society was the apogee of social development. Onegin might not be at home in the provincial world of the Larins but he could quickly strike up a friendship with the young poet Lenskii who was roughly speaking from his own world. Provincialdom versus metropolitanism, like the whole vexed question of in-laws and marital relationships (a paragraph and more of vigorous digression puffed out his argument), preoccupied Belinskii at this point, until he returned to the subject of Onegin and labelled him not cold, not dry, not hard-hearted, so much as one with poetry in his soul and by no means ordinary, one who may appear immoral in spirit and embittered in mind, but it was not his nature, not his passions nor his personal blunders that made him so, it was the age. Similarly, if he was an egoist, then he was to be considered a suffering egoist, fated to such egotistical suffering by his society and his time, since in Belinskii's view, somewhat in opposition to Pushkin's, evil was to be found not in man but in society. 'At twenty-six,' he was obliged to admit in assessing Onegin, 'to have experienced so much without having tasted the sweets of life, to be so enfeebled, so tired without having done anything, to reach such unconditional negativity without having come across any convictions: that is 
death!' (VII, 463) It was not death, of course, he encountered on returning to St Petersburg but Tatiana transformed from the provincial girl he had once rejected into a woman graced with a high-society oreole that could not fail to lend her distinction in his eyes. His love for her and her final rejection of him hardly excited Belinskii's interest at this juncture. Onegin was fated to behave as he did, we are told, but there was ultimately promise of his rejuvenation by contrast with Lenskii, his victim, who was conceived of as a romantic never destined to develop had he lived; though many of his type still persisted in society as 'the most unbearable, most empty and trashy of human beings.'(VII, 472)

The ninth Pushkin article, devoted to Tatiana, reads at its opening like a tract for female emancipation. Shades, one feels, of domestic discussions with wife and sister-in-law can be detected in some of Belinskii's comments, especially in the emphasis given to Tatiana's exceptional qualities, her profound, loving and passionate nature, for example, rather than her looks. She was not strictly comparable to an 'ideal heroine' (ideal'naia deva); her natural simplicity and need for love preserved her from the comic aspects of such a type. Moreover, she understood herself as little as she knew and understood Onegin, and she needed to know him if she were to understand herself. The conscious act of understanding began with her visit to Onegin's house after he had departed on his travels following the death of Lenskii. What it revealed to her was initially joyless and depressing. It forced her to abandon her bookish dreams, to accept the reality of what she found and, should she wish to live the life of her heart, to do so only in the depths of her soul. 'The visit to Onegin's house,' Belinskii commented, 'and the reading of his books prepared Tatiana for her transformation from a country girl into the high-society lady who so surprised and astonished Onegin.' (VII, 498) Although the final confrontation between hero and heroine is then discussed briefly, the argument appears to become confused towards the end of the treatment by digressing somewhat inconclusively into a comparison between Tatiana and Vera (of Lermontov's novel) and asserting above all the typicality of the Pushkinian heroine. The issue of typicality, of course, was important for Belinskii's interpretation of the work as a whole. 'Thus,' he wrote, 'in the figure of Onegin, of Lenskii and of Tatiana Pushkin depicted Russian society in one of its phases of development, and with as much truthfulness and as much faithfulness as he ever fully and artistically depicted it!' (VII, 502)

In conclusion came the famous description of Eugene Onegin as 'an encyclopedia of Russian life and a national [narodnyi] work in the fullest degree' and 'an act of consciousness for Russian society, almost the first 
such act, but what an enormous step forward for it!... This step was like the blow of a bogatyr's sword, and afterwards standing still became impossible...' (VII, 503) ${ }^{18}$ Progress, in short, was the conclusion to be drawn from Pushkin's masterpiece and was soon to become Belinskii's watchword. His hope for Russian literature as progressive, always of course latent in all his previous assessments, now asssumed a more specific character.

It is to be discerned, as a kind of epilogue to the interpretation of Eugene Onegin, in the socio-political implication of the treatment given to Pushkin's only major drama, Boris Godunov. In his penultimate Pushkin article, composed presumably in the late summer and early autumn of 1845 , Belinskii could write with the authority of a practitioner on the merits and weaknesses of the drama and did so; but the social and political implications of Godunov's tragedy were what concerned him most. He was prepared to single out sections of the historical drama for praise, especially the monologue of the monk Pimen, but the work as a whole suffered from the fact that history - or Karamzin's version of it as interpreted by Pushkin - was basically to blame for its undramatic nature. The work was really a kind of epic poem in dialogue form. ${ }^{19}$

Easily discernible in such an approach was the further - subversive - critique of the central figure of Godunov himself. In political terms, unless the ruler were a true genius like Peter the Great, he had to acquire the love of the people, for the voice of the people was equivalent to the voice of God; and Godunov never received such divine approval. His

18 Pisarev violently disagreed: '... Eugene Onegin cannot be called either the first or an enormous or any kind of step forward in the intellectual life of our society. As for it being like the blow of a bogatyr's sword or the impossibility of standing still after Eugene Onegin, it goes without saying that a reader faced with such bold and purely fantastic hyperbole can only stop and smile, shrug and recall that recent past which, with each passing minute, like a stubborn and poorly treated disease, still makes itself felt at the present time.' (op. cit., p. 253). Pisarev, it has to be pointed out, had in mind the fact that, although serfdom had been abolished in 1861, a serf culture (upon which, of course, the world of Pushkin's time subsisted) was still much in evidence in Russian society in the mid-1860s.

19 It is undeniable that nowadays the work is known virtually exclusively through the famous opera by Musorgskii. Belinskii's suggestion that Karamzin's history may have influenced Pushkin unduly is not borne out by a comparison between the history and Pushkin's text. 
reputation was tainted from the start by the suspicion that he was responsible for the murder of the rightful heir to the Muscovite throne and the consequent appearance of a Pretender not only highlighted this likelihood in the popular mind, it was the pretext for Godunov's own anguished sense of guilt at his illegitimacy as a ruler. Belinskii piled Pelion on Ossa by suggesting that, for all his cleverness, Godunov was more of a minister than a king, a parvenu, a man without ideas or principles, cleverer than his time, for sure, but not above his time, and guilty through introducing serfdom of reifying the peasantry, of transforming personae into res. As a result, he could not help being a tyrant.

As political critique concealed within literary exegesis, this was masterly, but Belinskii pressed home the socio-political implication by suggesting that Pushkin himself was too traditional in his views to understand such an interpretation of Godunov's place in history. Pushkin was in spirit more of a landowner, a member of the nobility, conservative and anti-Byronic than one should anticipate in a poet. The real meaning of Boris Godunov's story and Pushkin's treatment of it was evident almost by default, not through his portrayal as a monster like Shakespeare's Richard III but rather through his portrayal as a remarkable man who had been destined by fate to do something beyond his powers. When called upon to acclaim the Pretender as Godunov's successor, the people are silent. Belinskii glossed this with: 'This is the final word of the tragedy which contains within it a profundity worthy of Shakespeare... In the people's silence one may hear the awful, tragic voice of a new Nemesis pronouncing judgement over a new victim - over those who destroyed the Godunov line...' (VII, 534) By implication, those who destroyed the Godunov line were the Romanovs. Belinskii's words, as well as the three dots, had a deeply ironic but pertinent political meaning.

One may increasingly discern such political meaning in the final article on Pushkin, even if the social satire is more obvious. That Belinskii chose to open the article by examining the fragment 'The Genealogy of My Hero' (Rodoslovnaia moego geroia) could scarcely be accidental. The humorous, yet sharp-edged commentary had the serious purpose of pointing the finger of scorn at privilege, at the gentry, at aristocratism; and the immediately ensuing examination of The Bronze Horseman stressed that the Eugene who was its hero had no need of a genealogy, just as the entire meaning of the poem was in the confrontation between 'the giant on the bronze horse,' the personification of rational will, and the single individual who was a victim of historical necessity. Though the poem was declared to be an apothesosis of Peter the Great, 'a colossal work' (VII, 547), its message was probably best summarised in the 
verdict on the short poem Galuba which, despite its Chechen' setting, had universal application in that it represented 'the eternal struggle of the general with the particular, of reason with authority and tradition, of human dignity with social barbarism!' (VII, 551)

The most affirmative judgements on Pushkin's achievement were to be found in Belinskii's interpretation of what are commonly known as the Little Tragedies. Of Pushkin's portrayal of Mephistopheles (in 'A scene from Faust') he wrote that he was no more than a shallow minor devil or eighteenth-century wit whose scepticism now induced yawns rather than disillusionment; and of Pushkin's Faust that he was little more than un homme blasé. But of 'The Feast in the Time of the Plague' he was more complimentary, proclaiming its idea as 'truly tragic' yet emphasising the 'graveyard lust' (VII,556) which it portrayed. ${ }^{20}$ If these were less than impressive assessments, his critiques of such minor masterpieces of verse drama as 'Mozart and Salieri', 'The Covetous Knight', 'Rusalka'21 and, most especially, 'The Stone Guest' were remarkably perceptive and appreciative. The examinations of these works, previously so neglected in Belinskii's opinion, demonstrated Pushkin's psychological mastery of small-scale portraiture and in this respect showed the critic at his best. They also emphasised the fact that Belinskii was throughout his study of Pushkin determined to concentrate on the poetry; and his faint praise for the prose works, not to mention his unfair dismissal of 'The Tales of Belkin' as 'beneath their time' (VII, 577), was consistent with this purpose.

His conclusion, at the end of article eleven, made fewer claims for his subject than might have been expected. The European models with whom Pushkin invited comparison - Goethe, for example, Shakespeare, Mozart - were little more than ghosts at the ultimate celebration of his achievement. All the emphasis was placed on the fact that 'Pushkin was primarily a poet and artist and could not be other than that by his very nature.' (VII, 579) This meant that he would forever be a great and

20 Based on John Wilson's The City of the Plague (first published in 1816), Belinskii evidently did not know the work even though he claimed it was 'great' and John Bayley commented quite justifiably in his Pushkin: A Comparative Commentary, C.U.P., 1971, p. 233 that [Belinskii] 'seems to miss the significance of Pushkin's adaptation.'

21 Belinskii was not to know, of course, that this work was not unfinished or fragmentary, as had long been supposed, but complete, as has been revealed in Vladimir Retsepter's The Return of Pushkin's Rusalka (illustrated by M. Chemiakin), Pushkin State Theatre Centre, Spb., 1998/Angel Books, 1998. Translated by Antony Wood. 
exemplary master of poetry, a teacher of the art, and his poetry would nurture in people a sense of elegance and a sense of humanity, by which was meant everlasting respect for the dignity of human beings as human beings. Pushkin by his very nature was loving, sympathetic, ready to offer the hand of friendship to anyone he considered 'a human being' despite - and Belinskii's precondition was noteworthy - 'his genealogical prejudices.' (Ibid.)

In other words, although Pushkin would in due course become a classic, Belinskii evidently found something missing. It is striking that no claims were made for Pushkin's international status. He might nurture a sense of humanity and human dignity and cultivate moral as well as esthetic feeling through his work, but there was a distinct reluctance on Belinskii's part to claim for him any lasting reputation that might equate with the greatest literary figures of the European past or present. And this limitation was due to Pushkin's background, it would seem, his traditionalism, his prejudices.

It was also due to the fact that in the three or so years since Belinskii began his study of Pushkin he had literally travelled far. This final article was published after his return from the only prolonged trip he ever made through Russia. From the experience came the truth about his native country which inspired him to write his famous Letter to Gogol, the most cogent and devastating critique of Russian backwardness ever written and his most passionate plea for justice and the role of literature in achieving it. 


\section{Chapter 9}

\section{The Discovery of Dostoevskii}

The first years of Belinskii's marriage were marked by growing frustration at having less money than he needed to support his wife Marie and his sister-in-law Agrippine. This put him increasingly at odds with Kraevskii over the poor remuneration he received for the enormous burden of reviewing. His literary friends helped financially up to a point, but on the whole they were at best lukewarm about his marriage and Marie herself. Agrippine naturally sprang to her sister's defence by claiming she was a high-minded, intelligent woman with a loving, selfless devotion to her husband, such as few women could match, who had to run her household under the twin constraints of penury and sickness. ${ }^{1}$

Marie left no memoir. It is to Agrippine we owe such glimpses as we have of Belinskii en famille. Of these the first concerned their summer holiday in a draughty dacha at Lesnoi outside St Petersburg. The weather was wet and cold and they huddled together for warmth on a divan with their pet dogs. On one occasion Agrippine dashed in to find Belinskii lying on the divan, the floor beside him spattered in coughed-up blood. On another occasion he fell off the divan and the dogs began playing with his long hair, at which he laughed so much he started coughing again. Then there was the time he did not finish his favourite glass of tea laced with rum and let the dogs have it. They fell about drunkenly and he laughed like a child and Marie scolded him, fearing they would go mad. At once he rushed out to the well and doused them with water till they were sober.

During the summer Turgenev used to make frequent visits. He was staying not far away at Pargolovo. On one occasion he recalled having

1 A.V. Orlova, Vosp. sov, pp. 566-7. Agrippine wrote her memoir in 1891 shortly after her sister's death, more than forty years after Belinskii's, and no doubt her recollection and her judgement may have been distorted by the lapse of time. 
spent two or three hours in excited conversation with Belinskii and was exhausted and hungry. Despite Marie's pleadings and reminders about the doctor's advice, Belinskii reproached him with the cry:

'We've not yet decided about the existence of God and you want to eat!'2

The existence of God should naturally have had priority, but as second best he learned from Turgenev about developments in Hegelian studies in addition to acquainting himself with Marx through reading Ketcher's translation of his critique of Hegelian philosophy, which in turn led him to express himself frankly to Herzen (letter of 26 January 1845):

'The truth I have taken upon myself is that in the words God and religion I see obscurity, fog, chains and the knout and I now love those two words as much as I love the four others. That's how it is, but as before I cannot say in print what I really think and why. What's the good of truth if it can't be popularised and broadcast? It's dead capital.' (XII, 250) ${ }^{3}$

It was 'dead capital' which only came to life in his Letter to Gogol and then through its notoriety. During this period he was much exercised by religious issues, as can be seen from Turgenev's evidence. Other evidence is supplied by Turgenev's literary rival, the young Fedor Dostoevskii, although he cannot be considered the most consistent or reliable witness to Belinskii's state of mind. When taxed by his friend Strakhov to clarify his thoughts at the beginning of the 1870 s while busy completing his most overtly political, anti-socialist novel The Possessed or Devils (Besy), he appeared to become almost incoherent with loathing at Belinskii's name. Particularly objectionable to him was the latter's attitude to Christ. ${ }^{4}$

2 I.S. Turgenev, Vosp. sov., p. 488.

3 As has been acknowledged (cf. Vol. XII, 531, n. 14), this 'truth' may reflect Marx's famous dictum that 'religion is the opium of the people.' Belinskii probably came across it in Ketcher's translation of Marx's article from the Deutsch-Franzosische Jahrbucher (Paris, 1844), a copy of which was said to be in his library.

4 'You never knew him, but I knew him and saw him and now I've understood him through and through. That man used foul language to me about Christ. He couldn't see what petty self-regard, malice, impatience, irritability and sheer baseness, but particularly self-regard, there was in him and in them. In abusing Christ he never asked himself what we could put in his place apart from ourselves when we're after all so repulsive. No, he never thought of himself as repulsive. He was self-satisfied in the highest degree, and this was a filthy, shameful insensitivity on his part. You say he was talented. He wasn't...' F.M. Dostoevskii, Pss., Vol. 29, bk 1, Leningrad, 1986, p. 215. Letter to Strakhov of 18 (30) May 1871 from Dresden. 
He was never, of course, really close to Belinskii, who was ten years his senior, but there is little doubt that he was influenced by him in the period of their first meeting, in 1845-6. The hostility of his letter to Strakhov has to be set against what he said two years later in his The Diary of a Writer for 1873. Here he wrote:

'Belinskii was not predominantly a person given to thought, but he was wholeheartedly passionate at all times and throughout his entire life. My first work Poor Folk delighted him (afterwards, almost a year later, we drifted apart for different reasons, which are now, however, completely unimportant); but then, in the first days of our acquaintanceship, drawn to me with his whole heart, he at once threw himself, with the utmost wellintended haste, into the task of converting me to his beliefs. I don't exaggerate his fierce attraction to me, at least in the first months of our acquaintanceship. I found him a passionate socialist and he at once began talking to me about atheism. I found much of significance in this - to be precise, his astonishing sensitivity and unusual ability to be profoundly penetrated by an idea... Above all, valuing reason, science and realism, he understood better than anyone that reason, science and realism could only lead to an ant-hill world and not to the social "harmony" in which mankind could feel at home. He knew that moral issues were the basis of everything. He believed to distraction and unquestioningly in the new moral bases of socialism (of which not one so far has been pointed out, however, apart from some disgusting perversions of nature and common sense); all he had was enthusiasm. But as a socialist he had to start by denigrating Christianity; he knew that the revolution would certainly begin with atheism...'5

Dostoevskii's abhorrence of atheistic socialism, so conspicuous in his thinking at the beginning of the 1870 s, must have influenced his view of Belinskii at this time because some four years later, in his The Diary of a Writer for 1877, he recalled their first meeting with true excitement and warmth. ${ }^{6}$ The recollection began with a description of Dostoevskii's visit to the poet Nekrasov on his deathbed and led to his recall of what happened when he first met Belinskii and became famous.

In 1845 he had been sharing a room in St Petersburg with D.V. Grigorovich. Both were keen to become writers, but Grigorovich had no idea what his rather secretive room-mate had been writing. Knowing that Nekrasov needed material for his projected Petersburg Almanac (Peter-

5 F.M. Dostoevskii, op. cit., Vol. 21, Leningrad, 1980, p. 10.

6 What follows is based on F.M. Dostoevskii, op. cit., Vol. 25, Leningrad, 1983, pp. 28-31. 
burgskii sbornik), he showed him Dostoevskii's manuscript. Unaware that it was a short epistolary novel entitled Poor Folk (Bednye liudi), Nekrasov and Grigorovich thought they would read the first ten pages just to test its worth. They read the first ten pages, then the next ten and finally spent much of the night reading the whole work in ever deeper astonishment. So moved were they that, early in the morning, they burst in on a still wakeful Dostoevskii to congratulate him.

That very day Nekrasov took the manuscript to Belinskii.

'A new Gogol has appeared!' he cried.

'With you new Gogols grow like mushrooms,' Belinskii remarked tartly.

He took the manuscript and read it. When Nekrasov paid him a visit that evening to hear his verdict, Belinskii excitedly commanded that Dostoevskii be brought to him at once.

'I remember at first glance,' Dostoevskii wrote, 'being very struck by his appearance, by his nose and his forehead; I had imagined him as quite different - "the frightening, the terrible critic." He received me unusually solemnly and coldly. "Right, that's how it should be," I thought, but before a minute had passed everything changed and the solemn look left his face, he wasn't the great critic meeting a twenty-two-year-old firsttime author, he was solemn, so to speak, out of respect for the feelings he wanted to express to me as soon as he could and for the important things he was dying to tell me. He began a fiery speech, his eyes blazing.

" "Have you yourself any idea," he said over and over in a high-pitched voice, "what you've written here?" His voice used to become highpitched whenever he spoke with strong feeling. "It's only through your direct awareness as a writer that you've been able to write like this, but have you really understood the terrible truth you've revealed to us? It can't be that at twenty or so you've been able to understand it all.",

Belinskii went on to refer to the episode in the novel when Devushkin, the wretched civil servant clerk, was summoned to his superior and profoundly humiliated by a button flying off his uniform and running across the floor. The superior might have been indignant but instead took pity on Devushkin and handed him money. Endowed with a black humour and a psychological perception unique to Dostoevskii, such humiliation of a 'little man' naturally invited comparison with the plight of Gogol's Akakii Akakievich Bashmachkin in The Overcoat (Shinel'). To Belinskii, though, Devushkin's readiness to grovel in servile gratitude for his superior's favour was horrifying.

" "The entire horror of it is in that show of gratitude! It's a real tragedy! You've gone to the very heart of the matter, you've shown it all up in a 
flash! We, publicists and critics, merely rationalise things, but you as a writer, at one stroke, in a single image, have exhibited the very essence of it for all to see, so that one can literally feel it with one's fingers, so that the most unthinking reader can understand it! That's the secret of true artistry, that's the truth of art! That's how a writer should convey the truth! You have had the truth revealed to you and made manifest as a writer, you've received it as a gift. Treasure your gift and remain true to it and you'll be a great writer!"

'He said this to me at the time. He said the same thing about me later to many others who are still alive and can bear witness to it. I left him in a state of ecstasy. I stopped on the corner of the street where he lived, ${ }^{7}$ looked up at the sky, at the sunny day, at the people walking by and felt with my whole being, all of me, that I had experienced a moment of triumph in my life, I had made a breakthrough, something completely new had begun but something I had never imagined even in my wildest dreams. (I was a great dreamer at that time.) "And is it really true I'm as great as that?" I thought guiltily in uncertain excitement. Oh, don't laugh, I never again thought myself great, but at that moment it was hardly bearable! "Oh, I will be worthy of such praise, what people they are, what people! This is where there are real people! I will do my duty and try to be as fine as they are, I will remain true! Oh, how superficial I am, and if only Belinskii knew what rubbishy, shameful stuff I have inside me! And everyone says these literary people are arrogant and self-regarding! Yet these are the only real people in Russia, they alone, they alone know the truth, and truth and goodness are always victorious and always triumph over evil and vice, and we will win! Oh, to join them, to be with them!"

'This is what I thought and I recall that moment with the utmost clarity. And I could never forget it. It was the most exciting moment in my entire life. Remembering it in penal servitude, I always felt uplifted in spirit...'

Dostoevskii owed his initial, virtually overnight, fame to Belinskii's penetrating appraisal of Poor Folk. This was what he remembered into his maturity as the most exciting moment in his life despite the fact that he was later to repudiate and condemn what might be called the atheistic humanism of Belinski's thinking. The exalte interpretation of the human condition implicit in such humanism, its atheistic arrogance, was one of the factors in the critical duel between God-man and Man-God which so

7 The corner presumably of the Lopatin house on the Nevskii Prospect (No. 7 , now No. 68) and the Fontanka (No. 41, now No. 40). See V.A. Manuilov and G.P. Semenova, Belinskii v Peterburge, Lenizdat, 1979, p. 331. 
dominated Dostoevskii's thinking and found direct expression in the ideological pro and contra of The Possessed or Devils (Besy). It may well have had its source in the crisis that overtook his relationship with Belinskii in 1847. Joseph Frank has noted that in Dostoevskii's case 'the long-range effect of this crisis was to sharpen his sense of the absolute incompatibility between reason and faith. ${ }^{8}$

In Belinskii's case, for all his interest in ideas, he was always more moved by the pathos of the human predicament. Though he appraised Poor Folk very warmly, he published his sentiments within a review of Nekrasov's Petersburg Almanac ${ }^{9}$ to which he had himself contributed (though he carefully refrained from reviewing his own contribution) and ended his review with a lengthy quotation from Herzen's 'Caprices and Thoughts'. Part of the quotation posed a question of the utmost relevance and importance:

'Whenever I walk along streets, particularly late in the evening, when everything is quiet and dark and only here and there is there a dimly burning night-light or a guttering candle, I am filled with horror. Behind every wall I imagine the unfolding of a drama, behind every wall one can glimpse hot burning tears, tears no one knows about, tears of hopes deceived, tears carrying away not only youthful beliefs but all the beliefs of humanity, sometimes life itself. There are, of course, houses in which people eat and drink well the whole livelong day, grow fat and sleep away the whole night undisturbed, and yet even in such houses there may be a female relative who is bullied and oppressed, a maidservant, a manservant, someone or other whose life has been made a misery.

'Why should this be so?' (IX, 580)

This question posed by Herzen writing as Iskander underscored the philanthropic intent of the Almanac as a whole. It can also explain Belinskii's horror at Devushkin's servility in Poor Folk. As a question it went to the heart of Belinskii's humanitarianism and his evolving idea of the

8 Joseph Frank, Dostoevsky: The Seeds of Revolt, 1821-1849, London, 1977, p. 198.

9 This collection of new literary works, both prose and poetry, was generally recognised as a landmark publishing event in Russian literature during the 1840s. Published in 1846, it followed on the success of The Physiology of Petersburg (Fiziologiia Peterburga, 1845). Apart from Belinskii's own 'Thoughts and Notes on Russian Literature', it contained Dostoevskii's first work, Herzen's 'Caprices and Thoughts', 'Three Portraits' and 'The Landowner' by Turgenev and works by V.F. Odoevskii. Sollogub, Panaev and Maikov as well as poems by Nekrasov, among them his very moving ' $V$ doroge'. 
purpose of literature; and it exactly fitted his sentiments in reviewing Dostoevskii's first work and proclaiming aloud what he had said to the young author in private.

The most remarkable feature of Belinskii's appraisal was his confidence in placing Dostoevskii in direct line of descent from Pushkin and Gogol. Here was a new star in the literary firmament, an exponent of the new school of literature, the so-called 'natural school' 10 of which Gogol was proclaimed the head. In this connection Gogol was described as a writer having no forerunner in Russian literature and there was no one like him (nor could there be) in any foreign literature. Even though Dostoevskii owed something to Gogol, Belinskii prophesied that his debut with Poor Folk 'clearly shows the place Dostoevskii will occupy in Russian literature and the fact that, if he has not stood side-by-side with his forerunners as an equal, we will have to wait a long time before we have a talent who is closer to them.' (IX, 552)

As for his novel, it required close study for it to be understood properly and Belinskii summarised his main impression of it in the following way:

'In general the whole of this novel is deeply pervaded by a tragic element. And this tragic element is the more remarkable for being conveyed to the reader not only by the words but also by the thoughts of Makar Alekseevich [Devushkin]. At one and the same time to amuse and profoundly move a reader's soul, to make him smile through his tears what ability, what talent!' (IX, 554)

For what Belinskii had stressed throughout his review was the increasing naturalness of Russian literature, its 'true to life' quality, so that it was quite in keeping for him to stress the absence of all melodramatic and theatrical effects in Dostoevskii's first work. Nowadays few readers, one suspects, on reading Poor Folk would feel it offers such obvious promise of future greatness. But Belinskii did not stint in his praise of Dostoevskii's humour and originality, his humanitarianism and his sense of pathos. No beginning writer could have anticipated greater praise and appreciation. If Belinskii grew less enthusiastic later, this was due not so much to ideological misgivings on his part as to the fact that the element of the fantastic, the 'dreaminess' (mechtatel'nost'), became more marked in Dostoevskii's later work.

Turgenev's story 'Three Portraits' and his narrative poem 'The Landowner' were accorded due praise, but he, along with Louis Viardot, was singled out for having performed a particularly noteworthy service for

10 The term 'natural school' was not initially used by Belinskii; it was a pejorative term in its original sense as used by Bulgarin in The Northern Bee. 
Russian literature by translating Gogol into French. Greater praise still, though, was due to Herzen/Iskander for it was he, with his novel Who is Guilty?, who had posed the most significant question of all. Belinskii was content at the end of his review to leave it to the reader to decide whether humanity was as yet mature enough to provide an answer.

It was left to Belinskii's own contribution to the Almanac, his 'Thoughts and Notes on Russian Literature', to offer a definition of literature's new role. If Romanticism had yielded to a literature that had lost its exclusiveness and now mirrored society, that among the works most to be commended in this respect was Count Sollogub's Tarantass, subtitled 'impressions of a journey', then there still remained a further dimension to literature's purpose which Belinskii sought to emphasise. This was its civilising influence. Earlier claims that it should be a controller of social opinion were reinforced and redirected by the more general notion that it now encompassed 'the entire intellectual life and the entire poetry of our lives' (IX, 388) and that only in literature was individuality truly identifiable. This notion was to give rise later to the stress laid on 'personality' (lichnost'), but for the present Belinskii drew attention to the disunity evident among the social classes in Russia and the need for society, as he conceived it, to unify, to achieve sociabilité, to become an organic whole. The Petrine reforms had undermined the walls dividing the classes; the railways would break down those walls more swiftly still and help create the cohesion necessary for social growth; yet civilisation could only be achieved through the direct influence of literature on the ideas and morals of society. Such a process had begun with Lomonosov and had made literature both a source of practical morality and a means of unfying people in a social sense.

Such assertions could well have a hollow ring to them, Belinskii admitted, since Russian literature was still in its infancy. Moreover, the Russian national character was given to extremes. All claims for literature's role were to be qualified by acknowledging that, though with Gogol it might have become exclusively Russian in its orientation, it remained virtually unknown in Europe and was as yet barely a national literature, let alone universal. Just as Russian nationhood was questionable, so there was no Russian poet who could strictly speaking stand in comparison with Europe's best. The need was for content in literature, of the kind, that is to say, admired by the French and generally of a European standard. Of still greater urgency was the need for talent, if not for genius. In this connection Belinskii ended his musings by referring to genius as the kind of personality whose work was so original it could not be imitated. ${ }^{11} \mathrm{He}$ was

11 Belinskii claimed at this point that the most obvious genius in Russian literature in this sense was the fabulist Krylov, though his own review of Krylov's work scarcely illustrated this to the full. 
to return to this issue of personality and nationality in his penultimate review of Russian literature (for 1846) which was to prove of lasting value for the orientation of the leading radical journal of its day, The Contemporary (Sovremennik).

\section{$* * *$}

A couple of years after his marriage (in his letter of 26 January 1845) he was able to inform Herzen that in the spring he was hoping to become a pater familiae because 'my wife is in that happy condition in which Queen Victoria of England finds herself at least two or three times a year' (XII, 250-1); and his daughter Olga was indeed born on 13 June that year and christened ten days. later. That summer a holiday dacha was hired in the region of Pergolovo and he unwisely bathed in the local lake. He contracted pneumonia and became so seriously ill his doctor feared for his life. He never recovered fully from this illness.

It left him more than ever anxious about his health and his financial future. The treadmill of reviewing to a deadline combined with these considerations and Kraevskii's vampire-like proclivity (as he put it in another letter to Herzen of 2 January 1846) for sucking the blood and soul out of his employee and then throwing out the remains like a squeezed lemon (he was to use the graphic metaphor more than once) finally made him decide to leave Fatherland Annals. Any unofficial work would be better. Almost simultaneously rumours sprang up about the founding of a new journal in St Petersburg.

Belinskii continued working for Kraevskii until April 1846. In the meantime he began collecting material for a literary almanac of his own. He persuaded Goncharov, for instance, to contribute his first novel $A n$ Ordinary Story (Obyknovennaia istoriia) and he obtained the promise of two works from Herzen. These and other contributions were finally handed over to Nekrasov late in 1846 for inclusion in early numbers of The Contemporary, a journal originally founded by Pushkin but rejuvenated in 1847 under Nekrasov's editorship.

What Belinskii knew he needed more than anything was a chance to rest and recoup. Physically close to exhaustion though he was, he seemed to have become more than ever outspoken as a result of his illness. Impatience with his physical weakness and the recognition that he had little time left tended to make him increasingly militant. Annenkov testified in his memoirs that Belinskii even caused ill-feeling among some of his former Moscow friends with his support for St 
Petersburg and his unwillingness to reconcile differences between the two 'parties' of Westernists and Slavophiles. ${ }^{12}$ Luckily old friendships proved robust enough to provide him with what, on the face of it, was the chance he sought.

12 P. V. Annenkov, Vosp. sov., pp. 420-35 


\section{The Journey to the South and the Letter to Gogol}

Belinskii's journey to the south, into what is now the Ukraine, occupied the six months from May to October 1846. It supplied him with a firsthand knowledge of provincial life and helped to fuel his anger on reading Gogol's Selected Passages from a Correspondence with Friends. His Letter to Gogol derived partly from this often painful journeying on dreadful roads to visit dirty provincial centres in Russia in the late spring and then to dusty, recently built towns along the northern shore of the Black Sea and the Crimea in the high summer of the year. Springtime mud and scorching summer heat left him wiser if not healthier.

Although financed and arranged by Herzen as a means of improving his health, it was actually a tour in the company of the famous actor M.S. Shchepkin and the itinerary was not of Belinskii's choosing. This fact alone made it hazardous. It began auspiciously enough with a very successful two-week visit to Moscow where he was feted by close friends and former enmities were put aside. As for more domestic matters, he informed Marie (letters of 1 and 4 May) he had lost a dental filling and worse - visited her father. The 'dearest one,' to whom he had referred disrespectfully in his love letters of 1843 , was a 'genuine representative of the absence of good and evil, emptiness personified' (XII, 276, letter of 4 May), who gave him tea, listened to news of Marie and Agrippine and then dwelt on his own poverty by complaining of the likelihood that he would be sent to a monastery on the death of his protectress, a princess.

The characteristically unflattering reference to Marie's father prompted a bickering, rather acerbic tone in subsequent letters. Again, as with the love letters of 1843 , we only have Belinskii's side of things and his letters were presumably preserved on his insistence, since he hoped to write a travelogue based on his journey to the south. Hardly surprisingly, the reference to 'the dearest one' provoked a cool response from Marie, to which Belinskii responded in a letter of 14 May by saying a little sharply: 'I wrote you about him not in a tone of reproof to you but I simply 
conveyed to you the impression which he produced on me.' (XII, 279) $\mathrm{He}$ went on to say he was delighted to learn that Olga now had a seventh tooth but annoyed by Marie's apparently neurotic despair at being badly treated by the apartment manager and taking everything so to heart that she had a pain in her chest and was likely to become bedridden. He was looking forward to more comforting letters from her, otherwise his journey would be far from happy. As it turned out, his correspondence with Marie over these summer months offered a barometric reading of the state of their marriage. There can be no doubt that Belinskii loved his wife, but she irritated him with her henpecking, her nerves, her complaints and the way in which she and her sister seemed to gang up against him. In a letter of 11-12 June he put it as succinctly as possible in reply to what she had written:

'You write that separation will make us more tractable to each other, but also more alien to each other. I think that both will be equally good. The first needs no explanation: it's clear of itself; the second's good because it'll give the opportunity of getting to know each other on a better basis. I am not at the stage in life to be comforted by fantasies, but I have also not yet reached the dry-as-dust despair of not knowing hope. And so I anticipate much good for both of us from our separation... I have always relied on a profound awareness that I have never had any wish to humiliate you, while you have always seen the facts but not my inner feelings and, so far as you are concerned, you have been right. If the separation makes you look into yourself more deeply and catch sight of what you have so far not been able to see in yourself, then it will be useful to us: we will be more indulgent, more patient towards each other's inadequacies and will explain them in terms of ill health, nervous irritability, lack of education and not in terms of bad feelings which, I hope, are foreign to both of us.' (XII, 283)

He had not, of course, walked out on his wife and daughter in making this trip to the south, though it might have appeared so. Some of the arrangements of Marie's own summer holiday at Gapsal' (Haapsalu) on the Baltic had probably been left to Dostoevskii and his brother Mikhail. ${ }^{1}$

1 Dostoevskii's letter to his brother of 26 April 1846 begged him to find a nanny for Belinskii's year-old daughter, preferably a German, not a Finn, he insisted. 'I am fond of and respect these people,' he wrote. '... M-me Belinskii, a very feeble, middle-aged woman in poor health, is obliged to travel all on her own and with a small child. You cannot be of better service to them. They are kind people, have a reasonable living and treat people admirably.' Dostoevskii sent this letter on the very day Belinskii left St Petersburg, so it must be assumed that the arrangements for Marie's holiday were still not complete before he left. F.M. Dostoevskii, Pss., Vol. 28, Leningrad, 1985, p. 122. 
In any case, judging from his letters, Belinskii remained irritated by Marie for one reason or another despite his love and his concern, above all, for little Olga. Cross purposes as well as his own inconsiderateness scarred the correspondence. He wondered, for example, why she wrote so prissily about being pregnant (letter of 8 July), yet he seemed to express little concern beyond a certain fretfulness for her nerves, her periodic ill health and her search for doctors in Revel', where Mikhail Dostoevskii was living and could doubtless find one for her. What is more (letter of 12 July), Agrippine had apparently been suggesting that he, Belinskii, had said disparaging things about Dostoevskii's relatives. She figured again at greater length in a letter of 30 July when he responded to Marie's description of her sister being seriously angry with him and spitting at his name because all his references to her had been offensive.

'Living together,' he wrote, 'I often had words with Agrippine (because - I repeat this under pain of being spat at once again - we both of us, she and I, have the worst possible characters - childishly petty, morbidly irritable, and neither of us has been educated to a mature awareness of what is called delicacy and tactfulness), but never, neither waking nor sleeping, have I nursed any hostile feelings towards her...' (XII, 304-5)

Obviously he was having to smoothe ruffled feathers in the family, but he could console himself with thoughts of little Olga, shocked though he was to learn she had been unwell for ten days (letter of 13 August). His spirits were restored by the receipt of a lock of her hair along with news of her recovery and by 4 September he had had a dream about her in which she was 'so pretty, so charming, and chattered away all the time and all of us watched her.' (XII, 315) Most of all he then looked forward to returning to St Petersburg.

The itinerary of his journey to the south took him from Moscow in midMay to Kaluga and then to Voronezh and Kursk. The weather had been good and his health had improved, but in Kursk heavy rain led to deep mud on the roads. If the conditions were appalling, there was the consolation of Mikhail Shchepkin's company. Kursk was where the actor's career had begun and the area was familiar to him. An expert raconteur, he kept Belinskii entertained, even though circumstances prevented him from acting before audiences until they reached Khar'kov where his 
performances were greatly appreciated. ${ }^{2}$ Belinskii's cough had improved meanwhile (letter of 14-15 June) despite the appalling roads and wayside halts and became markedly better when they reached Odessa. Here, if the sun were out and there were no wind (letter of 24 June), his chest felt much easier, but the moment a cloud obscured the sun and the wind picked up he would start coughing again, although not as badly as before.

They had travelled to Odessa by way of Ekaterinoslav, Potëmkin's projected southern capital, avoiding Kherson. Odessa proved to be delightful in its foreign, Italianate character. Their inn was situated at sea level, it seems, below the famous Odessa steps, and here Belinskii was able to have a bath in sea-water but even after four attempts failed to wash all the dust out of his hair. It was 35 degrees in the sun and the nights offered little respite from the heat. Shchepkin knew a doctor in Odessa who diagnosed Belinskii's cough as due not so much to a weak chest as to maladjustment of his entire organism, principally the nervous system. $\mathrm{He}$ assured the sick man he would return him home fully cured and prescribed sea bathing as a treatment. It did temporarily alleviate some of Belinskii's symptoms and he managed, for example, to climb the 200 steps into the city with only two stops on the way.

By early July he suffered a setback. He haemorrhaged and the sea bathing was stopped for a time. Though the heat and the dust of Odessa took their toll on his health, Shchepkin by contrast received plaudits for his acting from Odessa's cultured audiences. By mid-July, after moving to the naval port of Nikolaev, Belinskii was unable to sleep due to bedbugs, flies and the overwhelming heat and Shchepkin found the local actors absolutely abominable. Worse still, Nikolaev was devoid of schools or any kind of culture. The visit would have been unendurable had it not been for the Berkh family. Lieutenant-General Moritz Berkh (a rear-admiral of the fleet) was a keen reader of Belinskii's work and it was on his insistence that his relative, the young Alexander Berkh, later became closely associated with Belinskii in St Petersburg shortly before the latter's death.

Unhappily, on the eve of leaving Nikolaev their host's two-year-old little girl suddenly died. It was a bad omen. Belinskii's health had worsened; his chest was again hurting; he was constipated. Thankfully, the pills prescribed for him, after causing spasms, finally eased his chest

2 The most detailed account of Shchepkin's acting experience during the trip is to be found in Chapter VIII of V.S. Nechaeva, op. cit., Vol. IV, 1967, pp. $216-82$. 
pains and he was able to breathe better. By 13 August they found themselves stranded in Kherson surrounded by dusty, treeless steppeland and an appalling scarcity of greenery. It was from here he wrote the single most striking description of his whole trip:

'Last Tuesday I saw what was for me an amazing sight. I was travelling to have a bathe and saw terrible clouds of dust on the other side of the Dnepr rising in the direction of Kherson. I am looking at it and thinking, no, it's not dust, it's thick smoke, but where's it from and why? I hear alarm bells ringing out from one of towers in Kherson. That's strange, why should they be doing that? If it's a fire, it must be in one of the villages on the outskirts of Kherson. Finally I see it's not dust, it's not smoke, it's a cloud of locusts stretching for several miles and flying over Kherson. They were ringing the bells to frighten them and stop them settling on Kherson, otherwise they would have left not a single tree nor blade of grass untouched... The locusts I saw had already devoured en route all the reeds in the vicinity...' (XII, 310)

They left Kherson for Simferopol' in the Crimea on 26 August. Here a Dr Andrei Fedorovich Arendt urged him to inhale some herbal tobacco which proved a useful palliative and he enjoyed the town itself, its surroundings and the plentiful supplies of fresh melons and succulent grapes. ${ }^{3}$ They then had to move on to Sevastopol' for one of Shchepkin's engagements. Belinskii had grown a respectable enough beard meanwhile, or so he informed Herzen (letter of 6 September); and it was with this beard that he finally returned to St Petersburg in mid-October.

In the same letter to Herzen he noted jokingly that he and Shchepkin had seen three new types of nationality while travelling through the Crimean steppes: sheep, camels and Tartars. They all seemed to be different branches of the same tribe with one thing in common: 'They look exactly like Slavophiles.' He then added:

'But, alas, in the faces of the Tartars even the genuine, basic, eastern, patriarchal Slavophile look has been undermined by the influence of the cunning West: the Tartars for the most part wear their hair long but shave off their beards! Only the sheep and the camels stubbornly uphold the

3 A brief eye-witness account of Belinskii's stay in Simferopol' has survived. Apart from mentioning the general interest aroused by his presence in the town, it emphasised the poor state of his health and how frequently he would clasp his weak chest. I. Shmakov, Vosp. sov., pp. 552-5. 
sacred customs of their forefathers dating from the time of Kotoshikhin ${ }^{4}$ by having no opinions of their own, fearing an independent will and independent mind worse than the plague and eternally paying respect to their elders...' (XII, 316)

Belinskii may indeed have mentioned the Slavophiles and their fondness for sporting beards among other attributes of pre-Petrine Russia because he had himself grown a beard, but there was a more serious, hidden agenda at work here. It related directly to issues which became especially contentious in the light of Gogol's Selected Passages from a Correspondence with Friends because one of the 'friends' was a formidable lady, Aleksandra Osipovna Smirnova. She was the wife of the Governor-General of Kaluga and Belinskii met her during his visit to the town. 'C'est une dame de qualité' was his verdict, a woman supposedly unaffected by high society and 'a great friend of Gogol' (XII, 282, letter of 11-12 June). One account of their meeting - unflattering to Belinskii for obvious reasons - has been left by the Slavophile, Ivan Aksakov, who was staying in Kaluga at the time. He described how at first the critic began with polite exchanges but became annoyed by slighting references to George Sand's liberal ideas which in turn led Smirnova to condemn loudly the Frenchwoman's depravity and 'plebeian heart'. ${ }^{5}$ Belinskii's own recollections of the meeting were more complimentary to Smirnova, perhaps because her cool exterior ('cold as ice' (Ibid.), as he put it) was a reminder of Marie's and, in any case, such an opportunity for conversation was much preferable to staying in the unbearably cold, filthy conditions of his hotel room in Kaluga. He acknowledged, though, that he was invited to dine with Smirnova merely 'as a tail following in the wake of a fat comet' (Ibid.), i.e. as the travelling companion of the real celebrity, M.S. Shchepkin.

The hidden agenda to this meeting probably remained concealed from Belinskii to the end of his life. Smirnova was the recipient of several letters from Gogol. The first such letter in his Selected Passages 'Woman

4 Belinskii actually wrote Koshikhin. The reference is to G.K. Kotoshikhin (1630?-67), author of a famous critical description of pre-Petrine Russia, first published in 1840 , which was frequently used by Westernist writers to denigrate Slavophile claims about the superiority of pre-Petrine society.

5 I.S. Aksakov v ego pis'makh, Vol. I, M., 1888, pp. 337-8. Belinskii wrote warmly to Herzen about Ivan Aksakov (letter of 4 July from Odessa): 'A great young man! A Slavophile, but so good-looking he seemed no Slavophile at all. On the whole I am falling into a terrible heresy and beginning to think there might be some decent people amongst the Slavophiles. Sad to think so but the truth must out!' (XII, 296-7) 
in Society' (Zhenshchina v svete) had her as its addressee and urged her among other things to use her influence to stop bribe-taking among officials, since it was Gogol's belief that such bribe-taking was largely due to the cupidity of officials' wives. This was one measure of the fatuousness of Gogol's blinkered moralising. In a much longer letter reproduced almost word for word in his original version of the Selected Passages but prohibited by the censor on first publication, he admitted that his view of Russia was blinkered by ignorance. He urged Smirnova as wife of the Governor-General of Kaluga to provide him with as much information as she could about the town's officials. This did not prevent him from moralising about Russia and its present state from the far blue yonder of his European emigration - the letter in question in fact came from Prague ${ }^{6}$ - and showing some irritation at the way she had apparently claimed in a letter to him that 'It's sad and even wretched to see the state of Russia at first hand. ${ }^{7}$ Gogol did not want to imagine Russia as sad and wretched; he was concerned with present-day Russia and its potential for moral rejuvenation. Like hers, his final answer was religious. ${ }^{8}$

Belinskii very likely did not know of Gogol's letter since it could hardly have reached Smirnova before he met her. But he did know the religious bias in her Slavophile sympathies. It contrasted starkly with the religious fact of Russian life as he knew it. On the road to Kursk, for example, (on 8 June) near the site of a muddy fairground, he saw a religious procession engaged in carrying the icon of the Virgin Mary to the nearby monastery. 'Imagine twenty thousand people, packed tight and up to their knees in mud,' he wrote graphically but unemotionally to his wife (letter 11-12 June), 'who, after travelling some twenty miles, will lie down to sleep under the open sky, in mud and rain, in a temperature of only 5 degrees.' (XII, 284) He knew what it might be like because a short

6 N.V. Gogol', Pss.: Pis'ma, Vol. XIII, izd. 'Akad. nauk.', 1952, pp. 67-80.

7 Ibid., p. 79.

8 A.O. Smirnova (née Rosset) (1809-82) has enduring literary fame as the living prototype for Turgenev's portrait of Dar'ia Lasunskaia, mother of the heroine, in his first novel Rudin (1856). She was famous for knowing many of the leading literary figures of the period, but Turgenev's less than flattering portrayal was given a final twist from the lips of Bazarov in Fathers and Sons when, in Ch. 25, acknowledging his break with Arkadii, he spoke of feeling 'bloody awful' (prepakostno) just as if he had been reading and re-reading Gogol's letters to the wife of the Governor-General of Kaluga. In fact, Bazarov could hardly have had the opportunity to read, let alone re-read, Gogol's sententious apothegms in the letter to Smirnova since they were not published until 1860 and Bazarov supposedly died in 1859. 
while later his carriage became stuck in the mud and the peasants had to pull it out.

Stuck in the mud of its backwardness, Russia was unlikely to be pulled out by religion. Education, of course, was an answer, but Nikolaev demonstrated the cultural bankcruptcy only too clearly. Appalled at the state of the Russian provincial theatre, Belinskii intended to write an article about it, but any change in such cultural stagnation would take time and he was short of time. The influence of literature, on the other hand, especially a new journal, could make a fundamental difference. He returned to St Petersburg in the immediate expectation of becoming an editorial colleague, or even editor, of the newly reconstituted journal The Contemporary.

He was not well. Goncharov first met him personally in 1846 and was convinced his health had worsened since his trip. ${ }^{9}$ All the activity associated with the renewal of the journal also impacted on Belinskii's health. In turn, this may have been the reason why he did not join the editorial board of the journal; ${ }^{10}$ nor did he accept a contract of employment, although in all but name he was recognised as its guiding spirit.

He was happy, at least in one sense. Dostoevskii bore witness to this more than twenty-five years later in his The Diary of a Writer when, not without irony, he recalled being teased by Belinskii over the way the mention of Christ always brought tears to his eyes. The meeting betwen the two men very likely occurred in late 1846 , probably in the presence of Botkin who had recently returned from Europe. ${ }^{11}$ Belinskii claimed that if Christ were to be born again he would literally be eclipsed by contemporary science and contemporary leaders of humanity. He would become a socialist, meaning - so Dostoevskii was careful to point out - he would subscribe to the ideas of George Sand and Proudhon and Feuerbach, among others. Belinskii always pronounced the name Fierbach, so Dosto-

9 I.A. Goncharov, Vosp. sov., p. 533.

10 The editorial board of The Contemporary comprised Nikitenko, Panaev and Nekrasov, of whom the last was by far the most important.

11 Botkin had spent approximately three years in Europe. According to Annennkov, after the abrupt collapse of his marriage to Armance, he 'gave himself up completely to a life of sensuality' in Paris, to be followed by travels which led to his best-known work, Letters from Spain, published in The Contemporary in 1847 and in a separate edition ten years later. (P.V. Annenkov, Literaturnye vospominaniia, Gos. izd. khud. lit., 1960, p. 331) 
evskii claimed and added: 'With such a warm belief in his idea, he was, it goes without saying, the happiest of men.' 12

The recollection was naturally coloured by Dostoevskii's hostility. $\mathrm{He}$ dismissed the idea, for example, that Belinskii might have ended as a Slavophile but speculated that he might have gone into exile. He was probably 'the happiest of men' for the simple reason that he now had an opportunity to express his own vision of Russia's future in a forum largely of his own choosing. If the meeting with Dostoevskii occurred late in 1846, then it may well have been during Belinskii's drafting of his 'View of Russian literature for 1846' which claimed in its opening paragraph to be a programme statement for the new journal.

The distinctive feature of contemporary Russian literature, Belinskii asserted, was its ever greater closeness to life and reality and its consequent maturity. If this was not exactly new, nor was the subsequent historical survey of Russian literature from Peter the Great onwards. What was new was the concern with Slavophilism. The Slavophiles were, of course, hostile to the 'natural school' of Russian literature and its emphasis on the squalid aspects of Russian life. The number of their sympathisers was growing. Belinskii did not condemn them for their hostility, he condemned them for their negativity, the fact that the positive side of their doctrine amounted to no more than vague, mystical forebodings about the victory of the East over the West. Blind worship of the West for being non-Asiatic was equally obnoxious; what mattered was the humanitarianism of the West. In the context of Russian national life - the sole independent Slav nation, as Belinskii patriotically insisted - with a literature that had only existed approximately 107 years, the Slavophiles were nonetheless to be welcomed, even though their ideas might be directly opposed to his own.

The measure of this opposition, as of his own theoretical superiority, was the importance he now ascribed to 'personality' (lichnost'). A concept in some ways as indefinable as it was appealing, it was given a quasi-materialistic significance in Belinskii's interpretation by the stress he placed on the connection between body and mind: 'Mind is a human being in a body or - better - a human being through a body, in short, $a$ personality.' $(\mathrm{X}, 27)$ He illustrated what he meant by emphasising the role of love:

'When you fall in love with a woman, don't say you are fascinated by the beautiful qualities of her mind and heart, otherwise when someone else is pointed out to you who has superior moral qualities you will be

12 F.M. Dostoevskii, Vosp. sov., p. 522. 
obliged to abandon the first object of your love for a new one, as you might abandon a good book for a better one. It is impossible to deny the importance of moral qualities in a feeling of love, but when you love someone you love the whole of that person not as an idea but as a living personality; you love in that person particularly what you don't know how to define or name.' (Ibid.)

Geniuses were of course easily recognisable as personalities and created in their works worlds easily recognisable as their own, but definition of personality as such, as Belinskii admitted, was as much of a mystery as life itself. His principal object was to relate the idea to nationality (narodnost'):

'What personality is in relation to the idea of man, nationality is in relation to the idea of humanity. In other words, nationalities are the personalities of humanity. Without nationalities humanity would be a dead logical abstraction, a word without content, a sound without meaning.' (X, 28-9)

He would rather join the Slavophiles than remain on the side of the humanistic cosmopolitans over this question, since the former might be wrong but they would be wrong as human beings, whereas the latter would simply have logic on their side. Man can only be strong and secure in a society, but for a society to be secure it had to have the inner, immediate and organic links offered by nationality; and a nation should not be riven by competing divisions between majority and minority interests but by the competing interests of new versus old. In this struggle great men, always as national as their nation, have the special role of advocating the new versus the old, ideas versus empiricism, reason versus prejudice. 'Consequently,' Belinskii wrote, 'the source of all progress, of any forward movement, is not to be found in the duality of nations but in human nature itself, because that is also the source of deviations from the truth, backwardness and stagnation.' $(\mathrm{X}, 32)^{13}$

Progress in Russian society could therefore only be achieved by personalities who would advocate the new versus the old, ideas versus empiricism, reason versus prejudice. Unspoken but implicit in such a

13 This rather simplistic conclusion flew in the face of a dialectical approach, let alone a historical and dialectical materialist approach of the kind favoured by GV. Plekhanov, and was evidence of the way Belinskii had neglected 'dialectics' in favour of the notion that 'ideas govern the world.' It made him, as Plekhanov put it, a founding father of 'our educators' (nashikh prosvetitelei), Dobroliubov, that is to say, and other 'men of the sixties.' GV. Plekhanov, Estetika i sotsiologiia iskusstva. V dvukh tomakh, Vol. II, M., 1978, p. 209. 
programmatic statement was the idea of an intelligentsia and its role in promoting social progress.

As Belinskii went on to admit, the importance of such theoretical questions depended on their relationship to reality. In many cases Europe had already decided them; it remained for Russia to confront them and literature would be the forum. What followed as a revue of literature in 1846 emphasised in particular Dostoevskii's contribution. Not only was there the much-praised and highly popular Poor Folk which exactly matched the philanthropic concern with human reality advocated by Belinskii, but there was also The Double. It was a less successful work, in the critic's view, because of its 'fantastic coloration', yet a work in which 'the author has revealed the enormous power of his creativity and the character of the hero belongs among the most profound, bold and truthful concepts of which Russian literature can boast, intelligence and genuine truthfulness are limitless in this work, as also is artistic mastery.' $(X, 40)$ His main caveat was that the author had shown a frightful inability 'to control and manage economically his own excessive powers,' (Ibid.) which meant that he had been unable to place a reasonable restraint on the artistic development of his idea. Such criticism was always to accompany assessments of Dostoevskii's second work; less often was Belinskii's praise to be remembered. That praise was the high point of what was otherwise scarcely more than a bibliographical account of items published during the preceding year.

$* * *$

Much of his correspondence in the early months of 1847 was concerned with the business of The Contemporary and the state of his health. The two combined in a concern for money. Nekrasov as editor of the journal could not promise him enough money to go abroad for a cure, although he had shown Belinskii considerable generosity, financially speaking. The relations between the two men were generally good when they were not prickly. Botkin had promised he would try to find funds for Belinskii's trip abroad; so did Annenkov. Meanwhile, Herzen had been tardy in keeping his promise to help with the costs of the trip to the south. 'A poor man,' Belinskii observed (letter to Botkin of 7 February, 1847) 'is a social pariah.'(XII, 325) Poverty and poor health were foremost in his thoughts as the frosts of February grew more severe. He thought of abroad as he thought of new ideas and spent a couple of pages of a long letter to Botkin (17 February) giving his impression of the ideas of Auguste Comte, concluding with the thought that 'Genius is a great matter: like Gogol's Petrushka it carries its own smell about with it: Comte does not smell of 
genius.' (XII, 332) ${ }^{14}$ Belinskii had by this time become thoroughly mistrustful of systems. As he went on to say in connection with his own vague recall of Schelling's mystical ideas:

'Poor old humanity! That dear chap, Odoevskii, ${ }^{15}$ once assured me quite seriously that there's nothing separating insanity from a normal state of mind and you can't be sure anyone isn't insane. How true that is when applied to Schelling! Whoever has a system, a conviction, must be seriously concerned about his normal state of mind.' (Ibid.)

He was not systematic himself. His principal interest was the moral world of humanity, and of humanity those who most interested him, to whom he felt most drawn, were writers. When Turgenev left for abroad he addressed him (letter of 19 February) in the most superlatively affectionate terms and lamented his absence very greatly. He was, of course, already very appreciative of the early prose works which were to form the basis of Turgenev's reputation ( his famous Sketches from a Hunter's Album: Zapiski okhotnika), but he was even more appreciative of Turgenev as a friend and godfather to his recently born son. Turgenev, after all, was an oasis of sanity, whereas the affairs of The Contemporary were in genial disarray and kept going largely through good luck. It was a mad world, though, and little Olga knew as much. She found a picture of madmen in an illustrated journal and insisted that one of them looked exactly like Turgenev (Tentenev, as she called him).

She could well have insisted that the maddest of the lot was Nikolai Gogol. Belinskii's letters of early 1847 were full of references to Selected Passages from a Correspondence with Friends, 'surely the strangest and most edifying book ever to have appeared in the Russian language,' (X, 60 ) as he described it ironically in the opening sentence of his review of the book in January. Irony and mockery dominated his appraisal. The full extent of his distaste must remain in doubt because the censor apparently made serious cuts. What remained of the review contained lengthy quotes at which Belinskii had little trouble pointing the finger of scorn.

The book deserved an epigraph, he felt, such as 'Vanity of vanities, all is vanity' or Du sublime au ridicule il n'y a qu' un pas. His anger at Gogol could not help showing through when he mentioned such bizarre aspects of

14 August Comte (1798-1857), famed for his positivism and sociology, evidently had some influence on Belinskii's thinking. The idea of social progress offered in the review of literature was much more Comtean than Marxist. The name Petrushka refers to one of Chichikov's servants in Dead Souls.

15 V.F. Odoevskii (1804-69), a leading romantic writer, received several warm mentions from Belinskii and an extended review of his Collected Works when they were published in 1844. See Neil Cornwell, The Life, Times and Milieu of V.F. Odoyevsky, London, Athlone Press and Ohio UP, 1986. 
the work as Gogol's opening Last Will and Testament and his hope that his compatriots would buy it in large numbers for distribution to those who could not afford it and to ensure that he, Gogol, might afford to make a pilgrimage to the Holy Lands. As for the 'selected passages', the advice, that is to say, dispensed to readers, Belinskii stressed Gogol's selfconfessed illness amounting to religious mania, his sermonising tone, the fact that he taught, insisted, advised, exposed, blamed, forgave and generally behaved towards his readers like a curé $d u$ village. Particularly dreadful was the advice to a landowner to dispense justice to his peasants by ensuring that both parties to a dispute were punished equally regardless of right or wrong. The crude advice that peasants should be addressed as 'You unwashed snout, you!' (nevymytoe rylo! X, 69) elicited outrage. Worse still was Gogol's obscurantist notion that it would be wrong to teach illiterate peasants to read simply so that they could acquaint themselves with 'the useless little books European philanthropists publish for the masses.' (Ibid.)

On literary matters, of course, Gogol was entitled to be heard. His praise for Zhukovskii's translation of the Odyssey was welcomed, but how, Belinskii asked, would the masses of the people have access to it if they were illiterate? As for the four letters referring to Dead Souls and Gogol's own denial of his talent, Belinskii naturally concluded that this was grist to the mill of those who denigrated Gogol's works and defended his own praise of them by enquiring 'What's it to us that he does not recognise the worth of his own works if they have already been recognised by society? These are facts whose reality he himself is in no position to overturn...' (X, 76) Nor could Gogol escape the final censure: 'Woe to him whom nature has created as an artist, woe to him if, dissatisfied by the way he is going, he darts off down a route alien to him! He is bound to fall down on this new route, after which it may not always be possible to return to the right path...' (X, 77)

On the surface a somewhat restrained appraisal in view of Turgenev's assertion that Belinskii was 'a good hater.' Beneath the surface there is no doubt he harboured a deep and unforgiving anger at the Gogol who had so betrayed his high calling as Russia's foremost writer.

\section{$* * *$}

The death of his baby son came as a terrible blow. ${ }^{16}$ 'I am not alive, I am dying a slow death,' Belinskii wrote (XII, 353, letter to Turgenev of 12

16 Born on 27 November 1846, he was christened Vladimir and died in March the following year. The description of the medical treatment prescribed for the poor baby and Belinskii's inconsolable grief at his death can be found in A.V. Orlova, Vosp. sov., pp. 559-60. 
April). He was convinced now that he should move back to Moscow for financial as well as health reasons, but that would not be until he had returned from Europe hopefully cured of his tuberculosis. Early in May, he left St Petersburg for Salzbrunn by ship. The sea journey was terrible. As he explained to his wife (letter of 5 June/24 May), he knew now what it must have been like for negroes packed into the slave ships, so closepacked and unpleasant was the 'Vladimir' on which he sailed to Stettin. He had hoped Turgenev would meet him, but for some reason he did not arrive, so he managed to catch the train to Berlin and find the place where Turgenev was staying. At least in a physical sense he now began to feel better. His lack of German, though, and his social phobia made the inevitable meeting with Pauline Viardot ${ }^{17}$ (the singer was appearing in Meyerbeer's 'Les Huguenots') even more socially trying, since she inquired after his health and he understood not a word, whereupon she broke into Russian so comic she could not help laughing and he eventually understood what she meant and 'in the worst possible French, such as even horses can't speak,' (XII, 367) answered that he was better. He was invited to one of her concerts, though what she sang seemed to matter a lot less to him than the scenery along the Elbe. He was soon bored. He was a poor traveller, he had to admit, and homesick for his family.

Sickness was what most struck Annenkov on first seeing him at Salzbrunn. 'I scarcely recognised Belinskii,' he wrote. 'There stood before me an old man in a long jacket and a straight-peaked cap, a thick stick in his hand, who, as if taken by surprise from time to time, would quickly straighten up and try to put things right by looking the way he supposed he ought to. The attempts lasted no time at all and fooled no one. He looked like a man whose organism had been half destroyed. His face had grown white and smooth as porcelain and there was not a single healthy wrinkle in it that could indicate a man's persistent struggle against the advancing years. A terrible thinness and a hollow voice compounded the impression..." 18

Annenkov had learned of Belinskii's poor health from Botkin and had agreed to stay with him in Salzbrunn during his treatment. To start with,

17 Pauline Garcia-Viardot (1821-1910), the famous singer, became the object of Turgenev's affections in 1843. He remained devoted to her for the rest of his life and his visits abroad were largely dictated by her operatic engagements, especially during the 1840s. Incongruously, perhaps, in view of this, he was also on terms of close friendship with her husband, Louis Viardot (1800-83).

18 P.V. Annenkov, Vosp. sov., pp. 436-7. 
under the the guidance of a Dr Zemplin, Belinskii went on a diet, took the spa waters and his health improved, but he was soon complaining about the doctor as a charlatan (letter to Marie of 16 June) and making plans to go to Paris. Meanwhile, he would be up early each morning to visit the spa and be home before Annenkov was awake. With Turgenev he engaged in amiable arguments which always began with the admonition 'Boy, take care or I'll put you in the corner' 19 and ended with the boy - Turgenev - telling him home truths or whiling away the time with anecdotes that could provoke such spasms of laughter Belinskii would instantly be assailed by paroxysms of coughing. Soon Turgenev was fending off boredom by working on his most outspoken sketch against serfdom 'Bailiff' (Burmistr) ${ }^{20}$ with its brilliant portrait of Penochkin, the foppishly elegant landowner who was so callous towards his serfs. 'What a bastard with refined tastes!' was Belinskii's verdict on hearing it, but even Belinskii's praise could not detain Turgenev longer in the sick world of Salzbrunn. He left and went to London, exactly why is unclear, but was ready to meet up with his friends in Paris the following month. However, just as they were themselves about to leave for Paris a few days later Annenkov received a letter from Gogol along with one addressed to Belinskii. It contained Gogol's hurt, self-justifying response to Belinskii's review in which he claimed the critic had looked at his book 'with the eyes of an angry man,' concluding with the words 'I find it hard, very hard (I mean this sincerely) when personal hatred towards me is felt by an evil man, let alone a good man, and I have always considered you a good man. Here you have a sincere expression of my feelings!'21

This was the spark that ignited the dry tinder of Belinskii's anger.

Why? The most obvious single reason was Gogol's assumption that the anger, easily discernible beneath the surface of the review, was personal. The critic's anger was grounded in issues of far more pressing and national import than the merely personal. It had its source in Belinskii's life-long moral idealism, his private search for ideological answers, his own proneness to error, his own recent first-hand experience of Russian backwardness, his acquaintanceship with the leading growingpoints of European radical thought - Comte, for example, Proudhon, Marx (Annenkov must have spoken about him because he had recently

19 Ibid., p. 438.

20 Turgenev also very likely worked on an equally bitter indictment of serfdom, his sketch 'The Office' (Kontora), while in Salzbrunn.

21 N.V. Gogol', op. cit., pp. 329, 330. 
met him) and Stirner ${ }^{22}$ - and it sprang, as anger, from the twofold sense that he himself, Vissarion Belinskii, had somehow to justify himself and that his love and advocacy of Russian literature, his vision of its purpose, were now, like his health, under serious mortal threat.

As Annenkov testified, Belinskii had told him once how he felt: 'It's no good being ill, even worse dying, but to be ill and die with the thought that you'll leave nothing behind you on this earth - that's worst of all. What have I done? I wanted to finish my history of Russian poetry and literature, but there's no point in thinking about that now. If I had finished it, maybe someone would have remembered me, but now? I know what you want to say... but two or three articles, after all, half of which were taken up with contemporary nonsense no one cares about now, do not amount to a legacy. ${ }^{23}$

On receipt of Gogol's letter, which he took as a challenge to everything he stood for, he turned the small room adjoining his bedroom into a study and used the round table at which he and Annenkov had whiled away the evenings with boring card games as a writing table. Every morning for three days he worked at his reply taciturnly and concentratedly, making pencil drafts to start with on odd sheets and then producing a final version in ink, accompanied by a copy for himself. He had the time, in short, to produce a finished work, unlike the hectic pace at which he was usually obliged to write his St Petersburg articles. The result was also an article after its fashion, but, as Annenkov remarked, 'written under a different sky... ${ }^{24}$

Written freely, in fact, without the constraint of censorship. The famous Letter to Gogol was Belinskii's masterpiece because he was able to

22 On Stirner and Belinskii's reaction to Der Einziger und sein Eigenthum, see P.V. Annenkov, Vosp. sov., pp. 441-6. On Annenkov's meeting with Marx and the discussion of Proudhon, see P.V. Annenkov, Literaturnye vospominaniia, Gos. izd. khud. lit., 1960, pp. 301-6.

23 P.V. Annenkov, Vosp. sov., p. 442. Annenkov was the sole eyewitness to have left testimony of the Salzbrunn stay and he wrote his memoirs almost a quarter of a century after the event. His word-for-word recall of Belinskii's statements must seem implausible at such a remove, but their gist was no doubt correctly recollected, as were the details of daily life. It is ironic that he should have acted as a kind of literary attendant midwife both to Gogol's masterpiece, Dead Souls (Part I), when he helped Gogol with the final text in Rome in 1841, and to Belinskii's masterpiece, his Letter to Gogol, in Salzbrunn six years later.

24 Ibid. p. 454. 
express his feelings openly. ${ }^{25}$ Put bluntly, he declared: 'One cannot be silent when, under the cover of religion and in defence of the knout, falsehood and immorality are preached as truth and virtue.' $(X, 212)$

He had loved Gogol with all the passion that a man bound by ties of blood to his country can love its hope, its honour, its fame, one of its great men on the path to self-awareness, development and progress. The love which Belinskii professed here, however misguided, must be considered genuine, a clear acknowledgement of the love he had for Russian literature and the candid invective of what followed must be partly attributable to the feeling of a lover spurned in an intellectual sense, because the most serious charge he brought against Gogol was ignorance. Gogol knew Russia profoundly only as an artist, not as a thinking man, 'the role which you have so unsuccessfully taken upon yourself in your fantastic book.' $(\mathrm{X}, 213)$ This was not because Gogol was not a thinking man but because he did not know his country at first hand; he had looked at Russia only from his far blue yonder of Europe:

'Consequently you have not noticed that Russia sees its salvation not in mysticism, not in asceticism, not in pietism, but in the successes of civilisation, enlightenment and humanism. She does not need sermons (she has heard enough of them already!), does not need prayers (she's said enough of them already!), she needs an awakening in the people of a feeling of human dignity lost for so many centuries in dirt and filth, and rights and laws not consistent with the teachings of the church but with good sense and justice, and their strictest possible implementation. But instead of that it presents the terrible picture of a country where human beings trade in human beings without even the justification of the American plantation owners who argue that a negro is not a human being; a country where human beings are not called by proper names but by nicknames such as Vanka, Vaska, Steshka, Palashka; a country where, finally, there are no guarantees of individuality, honour and property, not even order imposed by the police, but merely enormous corporations of different official thieves and plunderers! The most vital contemporary questions in Russia now are: the abolition of serfdom, the outlawing of corporal punishment and the introduction of the strictest possible implementation of such laws as already exist.' (Ibid.)

25 The letter is available in an excellent English translation in A Documentary History of Russian Thought: From the Enlightenment to Marxism. Translated and edited by W.J. Leatherbarrow and D.C. Offord. Ardis, Ann Arbor, 1987, pp. 130-5. 
This was the programmatic statement that may have cost Dostoevskii ten years of his life spent in penal servitude and administrative exile for having read it aloud at a meeting of the Palm-Durov circle of the Petrashevskii group in mid-April $1849 .{ }^{26}$ This became Turgenev's credo. Hardly revolutionary on the face of it and essentially a re-statement of Belinskii's fundamental beliefs, it was written above all as an appeal for a sense of human dignity, for all that he conceived of as lichnost', in manifest outrage at the inhumanity of serfdom. Its open attack on serfdom was a distant echo of the appeal for freedom, justice and human dignity first expressed in Dmitrii Kalinin and justified so courageously in the letter the student Belinskii wrote to his parents.

The rest of the Letter to Gogol can easily be seen as a more personal development of this theme. As a great writer Gogol had used his artistry to show Russia her true image as in a mirror. He had now appeared with a book urging landowners to fleece their peasants, teach them verbal abuse, address them as 'unwashed snouts' and mete out arbitrary justice regardless of right or wrong. If Gogol had made an attempt on Belinskii's life he could not despise him more than he despised him for writing such shameful lines. If he had really been filled with Christian truth rather than with such a devilish doctrine, he would not have written his book. He would have taught the landowner to treat his peasants as brothers in Christ, either freeing them or making their labour worthwhile in recognition of his own falseness. Gogol's admonitions could hardly be the consequence of superior spiritual enlightenment as he claimed: they were the result of sickness or worse, and Belinskii did not care to speculate what that could be.

At which point he issued his most damning and famous condemnation:

'Proponent of the knout, apostle of ignorance, upholder of obscurantism and the black arts, panegyrist of Tartar morals, what are you doing? Look down at your feet, you're standing above an abyss!' (X, 214)

The abyss was the Orthodox Church which had always advocated the knout and despotism. Why, Belinskii asked, should Gogol include Christ in such institutionalised tyranny? He had been the first to teach freedom, equality and brotherhood, had proved the truth of his teaching by his martyrdom and been the salvation of the people until the church in its orthodoxy had become a hierarchy and a champion of inequality, a licks-

26 For the best description in English of this event and the circumstances surrounding it, see Joseph Frank, Dostoevsky: The Seeds of Revolution, 1821-1849, Princeton University Press and London (Robson Books), 1977, pp. 286-91. 
pittle of authority and the enemy and persecutor of brotherhood among men. It was the philosophical ideas of the eighteenth century that had revealed once more Christ's word.

'Which is why,' he went on in a superlative passage, 'some Voltaire or other, extinguishing with the weapon of his ridicule the bonfires of fanaticism and ignorance throughout Europe, is more a son of Christ, flesh of his flesh, bone of his bone, than all your priests, bishops, metropolitans and patriarchs!' (X, 214-5)

Belinskii's anticlericalism, expressed so clearly at this point, served to preface his further assertion that the Russian people were profoundly atheistic. True religious feeling prevailed only among the Raskol sects, ${ }^{27}$ a notion which he immediately linked to Gogol's eulogising of the Russian people's love for their rulers. This had so lowered Gogol's reputation in the eyes even of those closest to him that Belinskii himself could only ascribe what he sarcastically called such 'contemplation of the divine beauty of autocracy' $(X, 215)$ to the fact of Gogol's absence from Russia. In close proximity such autocracy was neither so beautiful, nor so harmless. And Gogol's worship of such earthly rather than heavenly authority could only be attributed to what was psychiatrically known as religious mania.

As for the claim that literacy was positively harmful for the mass of the people, Gogol's Byzantine God might forgive him for saying so, but this and his other teachings, apart from being inconsistent, had been considered signs of his madness - or worse - evidence that he was aiming to become tutor to the heir to the throne! In any case, he did not understand the Russian public, Belinskii argued, nor the fresh forces appearing in Russian society which, however oppressed and apathetic, looked to literature, for:

' $\ldots$ only in literature, despite the Tartar censorship, is there still vitality and movement forward. That is why the vocation of writer is so honoured among us, why literary success is so easy among us even for those of little talent. The title of poet and the calling of a literary man have for us long since eclipsed the gold braid of epaulettes and multicoloured uniforms.' $(\mathrm{X}, 217)$ Gogol had dishonoured his calling as well as himself with his book; and the public had been right to reject it because 'it sees in Russian writers its only leaders, defenders and saviours from Russian autocracy,

27 Raskol (i.e. schismatic) refers to the Old Believer sects who opposed the reforms in church ritual initiated by Metropolitan Nikon in the 1660s and were persecuted. Their best-known martyr was Archpriest Avvakum, whose Life was their most important literary monument. 
orthodoxy and nationalism and is therefore always ready to forgive a writer a bad book but not an evil one.' (X, 217-8)

The assertions of this paragraph were the most seditious of any that Belinskii made in his Letter to Gogol. By implication he endowed the role of a writer in Russia with responsibility for opposition to the official view of nationalism, although this counted for less in the last resort than the responsibility for vitality, for what could be considered progress, for differentiation between good and evil, since, as Belinskii was quick to point out, Russians generally had a deep, if as yet undeveloped, instinct for the truth. They did not need to make pilgrimages to Jerusalem to discern who truly carried Christ in their hearts, who truly suffered at the sight of others' suffering. This was the final major charge he brought against Gogol. 'No,' he wrote, 'you are merely blinkered, not enlightened; you have understood neither the spirit nor the form of the Christianity of our time. It is not the truth of Christian teaching but a sickly fear of death, of the devil and of hell that emanates from your book!' $(\mathrm{X}, 218)$

The remaining passages of the letter indicted Gogol for the crudity of his language, referred to peripheral matters and concluded with a re-assertion of the letter's main intent, that it was not a question of their respective personalities but of the truth, Russian society and Russia herself. If Gogol were truly humble, he would renounce his latest book as he had previously renounced his great works and make amends by producing new works reminiscent of them. The letter was dated 15 July 1847.

Annenkov felt Belinskii had been too harsh, and it might indeed seem he had gone in for overkill, but when Herzen first heard the letter read out after Belinskii and Annenkov reached Paris a few days later he whispered in the latter's ear the prescient words:

'It's a work of genius - and I think it's his last word too!'28

\section{***}

Was Gogol's very personal, even private work, his 'book of letters', as it has been called, ${ }^{29}$ really a fit object for such an attack? Had Belinskii

28 P.V. Annenkov, Vosp. sov., p.456.

29 This is the description used in the recently published monograph by the late Iu.

D. Margolis Kniga N.V. Gogolia 'Vybrannye mesta iz perepiski s druz'iami': Osnovnye vekhi istorii vospriiatiia, Spb., 1998. The Introduction (pp.6-20) offers a condensed but valuable description of the main polemical issues raised by the varying interpretations of Gogol's last work and is particularly interesting for its discussion of the academic furore occasioned by the publication of I.P. Zolotusskii's Gogol' (M., 1979; reprinted 1984). 
really understood it? Was his letter really not excessive? After all, so far as we know, he did not have a copy with him in Salzbrunn when he composed his Letter to Gogol and presumably did not re-read it prior to writing. And what was Gogol's response?

It was apparently twofold. First came a letter of 10 August from Ostend admitting he had been shaken to the core and conceding that Belinskii's letter contained a partial truth, although he had received fifty or so letters in response to his book, all different. He was bound to concede also that he did not know Russia and could not produce living images (zhivykh obrazov), as he put it, until he had revisited it. If the upcoming age was one of rational awareness, then it should be viewed from many different angles, and we - here he included Belinskii, it seemed - should be considered children in the face of it. Both he and his correspondent were therefore guilty of excess and he was prepared to admit it. He, Gogol, had concentrated too much on his inner self; Belinskii had flung himself in too many directions at once (vy slyshkom razbrosalis'). The conclusion was 'Just as I should learn much from what you know and is unknown to me, so you also should learn at least a bit of what I know and you are just neglecting. 30

This conciliatory, mild and seemingly balanced response turned out to be merely the tip of an iceberg of anger and hurt. Gogol had accumulated it slowly through a dozen and more draft pages of anguished, barely intelligible text. This was the second answer to Belinskii's letter and ostensibly the fullest. ${ }^{31}$

Because the text in the Russian must be regarded as far from definitive, ${ }^{32}$ Gogol's real meaning must often be in doubt. It opened with a reference to Belinskii's warning that Gogol was standing above an abyss, berated him for misconstruing his book, lamented his concern with politics and went on to express sorrow at his delusions. In a frankly rambling and untidy fashion the draft letter touched on such issues as

30 N.V. Gogol', op. cit., p. 361.

31 An English translation of this text was offered by Carl Proffer in his valuable edition of Gogol's letters, but for no very clear reason he combined it with the letter Gogol actually sent. Moreover, his translation gave no idea of the difficulties of interpretation, textual decipherment and likely variants that can be encountered in the fragmentary Russian text. See Letters of Nikolai Gogol, selected and edited by Carl Proffer, Michigan U.P., Ann Arbor, 1967, pp. 179-187.

32 N.V. Gogol', op. cit., pp. 435-46. 
Gogol's attempt to depict the Russian character, his mendicant role, his attitude towards the tsar, his disparagement of European civilisation, his defence of the 'good' Russian clergy, his mockery of Voltaire and a rather bizarre attribution to Pushkin of Francophobe lines by Polezhaev. The nub probably of his complaint against Belinskii was that he did not know the Russian people, spending all the time as he did in journalistic activities in St Petersburg (no account being taken of the recent trip to the south). Therefore, in a preacherly spirit quite in keeping with the tone of the Selected Passages, Gogol's advice to Belinskii was to stick to his critical last, as it were, remember that he was a university dropout and devote more time to reading great works rather than contemporary brochures.

Had Gogol actually sent this draft letter, there would have been proper grounds for Belinskii's attack. In the light of what we know, the charge of being excessive in his reaction might be justified, for in some respects he was as blinkered as his addressee. History, though, has largely judged otherwise. Herzen was quite accurate in the sense that even if the Letter to Gogol was not Belinskii's last utterance, it was he who undoubtedly had the last word.

Of course, he did not understand the inner, spiritual journey to which Gogol had committed himself as a means of depicting a morally rejuvenated Russia in the projected second and third parts of his masterpiece Dead Souls. Unfairly he attributed this to a self-deluding religious mania. In the final analysis, the collision between their views occurred at its most obvious in the role to be played by literature. If Gogol knew the anguish of a writer's task, the 'subjectivity' of his commitment to such a sullen craft and art, then Belinskii relied upon what he imagined was an 'objective' understanding of Russian society and the role of literature in that context. To this should be added his passionate conviction about the humanitarianism of the West, the need for Russian literature to be national as well as humanitarian and the special role assigned to all 'great men' in promoting the new versus the old, ideas versus empiricism, reason versus prejudice. It was here that his anti-Slavophile feeling emerged at its keenest. Slavophilism, therefore, with its appeal to the past and its negativity, as Belinskii saw it, was incompatible with a humanitarian literature designed to promote the new versus the old; and by this token, of course, Gogol had abrogated his right to leadership of Russian literature. Set in the context of their respective lives and personalities, though, this was a quarrel between two men at the end of their tether: Belinskii's an anger induced in part by physical illness, by an awareness of approaching death, Gogol's a resentment induced by what seems to 
have been increasing, but undiagnosed, mental illness, easily discernible as incipient in his last work. ${ }^{33}$

Belinskii's Letter to Gogol was the single most important document he ever wrote. A product of his genius for telling the truth as he saw it in his private correspondence, it ultimately demonstrated to the world his most cherished beliefs and hopes. Central to these was a vision of the Christian life which coloured all his thinking on social and political matters. It implied, for example, the identification of Christ and 'the Christianity of our time' with the ideals of the French revolution - liberty, equality, fraternity - and can be seen as the revolutionary subtext of the Letter. If the stated programme was one of limited political reform, the revolutionary spirit shone out of it through the excesses of the rhetoric. But the political message chimed in with the idea of a literature given the elevated role of a forum for airing all the vital questions of the day and for ensuring progress. Though the message had inherent in it the idealism and some of the Romanticism always present in Belinskii's thinking, equally unmistakable was the urgent, passionate commitment to the notion that writers, like the poet as Shelley conceived of his role, should be considered the unacknowledged legislators of the world.

33 Gogol's letter to Annenkov of 12 August 1847 demonstrated a similar sort of derangement in its frankly dotty defence of his case against Belinskii's charges by referring to his sincere conviction that all official posts in the Russian state (so one must assume) could be sanctified (osviashcheny) by man, and the higher such a post, the more sanctified it should be. Something very like mania must also be evident in his further claim to be reminding people of the sanctity of their obligations and his own prolonged effort to educate himself inwardly and analyse his own soul, etc. Although such confessional utterances related directly to Belinskii's letter, Gogol made a much fuller self-critical diagnosis in his 'Author's Confession', a work unpublished in his lifetime but supposedly composed between May and July 1847 in answer to hostile criticism aroused by his Selected Passages. 



\section{Chapter 11}

\section{Paris, Last Reviews and Death}

Belinskii had gone abroad 'in the solemn and sad conviction,' as he put it (letter to Kavelin, 22 November 1847), 'that my career was finished, that I had done everything I had been given to do, that I was worn to shreds, written out, said my last word and was like a lemon squeezed to a pulp for a glass of tea.' (XII, 431) In this context his Letter to Gogol might be thought of as no more than an item in his personal correspondence which became famous by accident. ${ }^{2}$ Once he had finished it, he continued with his planned trip to Paris.

En route he and Annenkov stopped in Dresden. His health was improved, he had to admit, though he still had difficulties with his cough, was breathless and headachy (letter to Marie, 7 July 1847). Shirts were apparently cheap in Dresden, so he ordered a dozen to be made in three days. Annenkov described him as being offended by the fleshly tones of Rubens in the art gallery. ${ }^{3} \mathrm{He}$ also complained that Raphael's 'Madonna' looked like 'an aristocratic woman, a daughter of the tsar, idéal sublime du comme il faut' (XII, 384, letter to Botkin, 7 July). The Christ child in her arms reminded him not so much of a future God of love, peace, forgiveness and salvation as of an old testament God of anger and ferocity, punishment and retribution. Yet the brilliance of the brushwork and its elegance called to mind a similar nobility of manner in Pushkin and he found it no wonder that Pushkin had loved Raphael because they were by nature of a piece. His discrimination as an art-lover was finally

1 A most valuable assessment of Kavelin's contribution to Russian liberal thought is to be found in Derek Offord's Portraits of Early Russian Liberals: A study in the thought of T.N. Granovsky, V.P. Botkin, P.V. Annenkov, A.V. Druzhinin and K.D. Kavelin, Cambridge U.P., 1985, pp. 175-213.

2 It came to be circulated in numerous copies in a form of early samizdat and was first published in Herzen's emigre journal The Polar Star (Poliarnaia zvezda) in 1855.

3 P.V. Annenkov, Vosp. sov., p 459. 
proved beyond doubt by his admiration for the female buttocks in Michelangelo's 'Leda and the Swan'.

He admitted to Botkin that he had learned one thing so far about Western Europe: he now knew what the words pauperism and proletariat really meant. He had witnessed poverty of a kind he had never seen in Russia. His native land might have crop failures and consequent hunger, landowners might treat their serfs like negroes and officials might thieve, but there was not the grinding poverty of a proletariat reduced to beggary as in the West. The revelation turned him against the Germans. He was especially annoyed by their habit of smoking cigars. It seriously affected his already weakened lungs on the protracted journey via Frankfurt and the Rhine to Cologne.

From Cologne they caught the train via Brussels to Paris, arriving at the beginning of August, and at once made their way to where Herzen and his wife were staying. The weather was now excellent. Writing to Marie (letter of 3 August), he described how Paris had exceeded all his dreams, all his expectations. The Tuileries, the Place de la Concorde, the Palais Royal were all like items from the Arabian Nights, part of the world of Scheherazade, places of fountains, chestnut trees, brightly lit shop windows. This was not so according to Turgenev. On arriving in Paris shortly after Belinskii, he found the latter's reactions to such sights slightly different. Having been assured that the Place de la Concorde was the finest square in the world, he behaved like a typical Russian, showed no further interest and started talking about Gogol. Told that it was the site of the guillotine where Louis XVII had been executed, he started talking about the execution scene in Taras Bul'ba. ${ }^{4}$

For some three weeks during the Paris visit he was treated for tuberculosis at a maison de santé in Passy. It was run by a doctor referred to by Belinskii as Tirat (de Melmor) and there can be little doubt that the treatment regime led to a temporary improvement in his health. By midAugust he could tell his wife that his cough had almost gone and there were some days when he did not cough at all, something he had not known for many years. A week later, though, (letter to Marie, 22 August) he had to admit he was not really better, but his doctor felt he was well enough to leave Passy and return to central Paris.

It was, of course, a Paris on the eve of the 1848 revolution. Dusty, crowded, noisy, it was not the healthiest of places and Belinskii, sick as he was, found theatre-going, museums and public lectures burdensome duties of which he was only too happy to be relieved. ${ }^{5}$ On the other hand, he was

4 Ibid., p. 510.

5 Ibid., pp. 460-1. 
happy to participate in vigorous discussion of political issues with Herzen, Michel Bakunin, Annenkov and others. Change was certainly in the air, though none of the participants in the discussions could have anticipated the revolutionary events to come. So far as one can determine, the arguments centred on the question of the bourgeoisie and the likelihood of imminent changes in Russia. Belinskii's advocacy of a new Peter the Great was challenged by Bakunin's faith in the natural revolutionism of the masses, just as Belinskii appeared to disagree with Herzen over the significance of the bourgeoisie, arguing that it was not an accidental phenomenon but a historical fact of the greatest consequence for humanity. ${ }^{6}$

However important these arguments were, and they appear to have had a determining effect on the orientation of Belinskii's thinking, they were overshadowed by his anxiety to be home. As his letters to his wife indicated, there was none of the contentiousness of the previous year. Personal matters naturally preoccupied him. For example, Herzen's wife, knowing Belinskii's fondness for his daughter, had assembled a number of toys and picture books for him to take back to her, just as he had bought for himself a showy dressing-gown which had caught his eye in a shop window. In a mixture of silk and cotton, it had large red designs along the edges. He was delighted with it.

Annenkov somewhat laconically tells the story of Belinskii's return journey to St Petersburg, how Turgenev reneged on his promise to accompany him to Berlin and went off to the Viardot home at Courtavenel instead, how Belinskii was given a new companion called Frederic, how he forgot his cherished dressing-gown and had to travel alone to Brussels where his French was inadequate to explain to the Belgian customs that the dutiable toys in his luggage were presents and he did not know their price. ${ }^{7}$ All ended satisfactorily with the customs official taking

6 The evidence for such discussions comes largely from Belinskii himself as outlined in his letter to Botkin of December 1847 and a letter to Annenkov dictated by him in February of the following year. The discussions, as well the letters, were prompted by Herzen's 'Letters from the Avenue Marigny', first published in The Contemporary late in 1847. The evidence is at best onesided, therefore, and inconclusive, much like Belinskii's own thoughts on the bourgeoisie and its significance; and one is bound to accept Martin Malia's somewhat bemused verdict that Belinskii's, like Herzen's, was 'a naively moralistic view of industrialization which shows how little the debaters understood the phenomenon they were discusing.' Martin Malia, Alexander Herzen and the Birth of Russian Socialism, Harvard U.P., 1961, p. 355.

7 P.V. Annenkov, op. cit., pp. 464-7. Belinskii's version of his return journey was given in somewhat greater detail in his letter to Anennkov of 17 September 1847. 
pity on the inarticulate traveller and Frederic arriving by a later train with the dressing-gown. The two then travelled to Berlin where Belinskii was handed into the safekeeping of D.M. Shchepkin, son of the famous actor, who accompanied him back to St Petersburg.

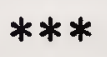

It is doubtful whether Belinskii had his mind fundamentally changed by his visit to the West, no more than his health was fundamentally improved. He was now engaged in an ever more desperate struggle both to prolong his life and to assert, as if it were a secular vision of paradise, the kind of future he hoped for Russian literature.

He admired the West but he clearly did not love it. He did not share Turgenev's degree of pro-Western cosmopolitanism. Too deeply Russian in his basic instincts, he was always more of a patriot than a citoyen $d u$ monde, but he never rejected the West on the simplistic grounds of its capitalism, its bourgeois standards or its exploitation of the working class. Always an idealist, he readily acknowledged the humanitarian ideals of advanced Western thought and became more and more conscious of both their radicalism and the need for radical means of implementing them.

But the immediate challenge to his own stance and reputation still came from the Slavophiles. In his first major article for The Contemporary after his return from Europe, he bitterly attacked Slavophile criticism of the new journal and a certain sniping at himself which had come from The Muscovite. His 'Answer to The Muscovite' ('Otvet Moskvitianinu'), though suffering from serious censorship cuts when first published, ${ }^{8}$ gave expression to his anger at the way the editorial principles of the new journal and the ideals of contemporary Russian literature were under attack. This was no longer a personal matter but a question of ideas and his answer echoed both the tone and the content of his Letter to Gogol. He implied a marked difference between Moscow and St Petersburg in literary attitude, condemned the restricted and elitist approach of the Muscovites, argued for freedom and catholicity of choice in journalistic policy and stoutly defended Gogol's contribution to Russian literature as leader of the 'natural school' by emphasising his talent for clearly exposing the 'spiritless mediocrity' (poshlost') of life in all the fullness of its reality and truth. The 'natural school', far from being derided and abused, had become uniquely popular; it demonstrated that Russia now had a literature of its own. Belinskii, as its principal advocate, was there-

8 It was apparently passed by the censorship at the end of October 1847. 
fore the chief target of the Slavophiles' attack and his 'Answer' was most notable for his angry defence of his own role as a true devotee of Russian literature by contrast with his critic's dilettantism: ${ }^{9}$

'The public knows how to tell the difference between a man whose literary activity was a vocation, a passion, who never kept his convictions separate from his interests, who, guided by an inbred instinct for the truth, had more influence on social opinion than many of his really learned opponents - and some gentleman or other who has studied the peasantry through his valet and thinks he loves them more than others because he has invented or adopted on faith a mystical theory about them, who, along with his official and worldy obligations, also occupies himself with literature in a dilettante fashion and hatches out year after year some article or other, having enough time to demonstrate in it his cleverness, his learning and maybe some talent...' (X, 262-3)

Belinskii sorely wished to know what, beyond a mystical worship of 'the people', the peasantry, Slavophilism actually was; and his mockery and derision must be attributable to inadequate awareness - no doubt partly deliberate - of Slavophile ideas. But his overwhelming concern at this time was defence of The Contemporary and what it stood for. He very nearly broke with his friend Botkin over the latter's decision to write for the hated Kraevskii's journal, for the only way in which the new journal could flourish was by attracting contributions away from its rival (letter to Botkin, 4-8 November, 1847). In any case, Kraevskii was a vampire who had sucked Belinskii's life-blood out of him. When, after returning to St Petersburg, he suddenly fell ill during a move to a new apartment, he was reminded once more of his fragile health. Thankfully he recovered sufficently to compose his answer to The Muscovite, to his doctor's surprise (letter to Annenkov, 20 November - 2 December, 1847), and the renewed vigour, however tragically shortlived, helped him to compose his final defence of The Contemporary in his last annual review of literature.

As for his private thoughts (letter to Kavelin of 22 November 1847), he reiterated his belief in his own country and its future while conceding that individual personality (lichnost') was only just emerging from its shell in Russia and that fact must account for the way in which Gogol's characters were still the truest depictions of Russian types. He also reiterated, in the face of Kavelin's charge of Slavophilism, his belief in Peter the Great 'my philosophy, my religion, my insight into everything concerning

9 The author of the personal attack on Belinskii's review of literature for 1846 was Iu. F. Samarin (1819-76) writing under the pseudonym of M... Z... K... Belinskii knew he was a bureaucrat and member of the nobility. 
Russia,' (XII, 433) as he enthusiastically put it. In further self-justification (letter of 7 December), he confessed that his strength lay not in his own talent but in his passion, 'in the subjective character of my nature, in the fact that my articles and I are always something indivisible' (XII, 455) a tacit acknowledgement, perhaps, that his work was coloured by genius of a kind. As for the ticklish question posed by his correspondent whether Russia could be said to have a positive side to it (which was, after all, the Slavophile claim), Belinskii had to admit to the private conviction that Russia was principally a country of extremes and monstrous, strange, incomprehensible exceptions, something as axiomatic for him as $2 \times 2=$ 4. In Russian life, he implied, only literature could speak the truth, the literature, that is to say, of the 'natural school', even though there lay a great divide between Gogol and this natural school of literature. Yet the 'natural school' still derived from him, he fathered it; he not only gave it form, he also indicated its content. Gogol may not have been conscious of playing such a role, but geniuses were like that. Despite being maddened by this idea earlier, Belinskii confessed he now considered it an axiom to which there were no exceptions. Peter the Great was no exception either:

'He wanted to make out of Russia something resembling Holland and construct out of St Petersburg a kind of Amsterdam. But was that all that came out of it or should have come out of his reforms? Genius is an instinct and from it comes revelation, it throws into the world an idea and impregnates the future with it, not knowing what it has done and not intending to do what it did! Talent acts consciously, but then it is a castrate, impotent; it doesn't give birth to anything of its own but instead it nurtures, brings up and fortifies the children of genius.' (XII, 461-2)

The abolition of serfdom, always of course at the forefront of Belinskii's expectations, was now under serious consideration by the government, or so he suggested in a digest of recent events which he included in a letter to Annenkov at the beginning of December 1847. On the other hand, his thoughts on other political issues took the form of disjointed pronouncements condemning 'Liberals' as misguided (along, incidentally, with the Ukrainian poet Shevchenko), interspersed with high praise for Dickens's Dombey and Son ${ }^{10}$ and comments (in his final letter to Botkin of December 1847) to the effect that a literary work should always give rise to questions and have a moral effect on society. The most important feature of his final letters was the extent to which they echoed the discussions held in Paris during the summer.

10 The novel was appearing in translation in both The Contemporary and Fatherland Annals. 
Their pretext was the publication in The Contemporary of Herzen's 'Letters from the Avenue Marigny', letters composed, Belinskii claimed, in his own presence and therefore vitally reflective of views expressed at the time. In an earlier long letter to Botkin (2-6 December 1847) he had admitted he did not agree with Herzen's negative assessment of the bourgeoisie but this did not mean he was not privy to anti-bourgeois feeling. No matter how silly it might be to condemn the bourgeoisie as 'a syphilitic sore on the body of France,' (XII, 447) the opposition, by pronouncing such an anathema, exhibited the only vitality and talent in French cultural life. What Belinskii condemned was not the bourgeoisie as such (insofar as he was prepared to define it) but the major capitalists and, above all, mercenary commercialism (torgash). Against those engaged in commerce. he launched all his slings and arrows, while reserving for the ordinary French and Russian working man characteristic anti-German approval for the way they sought to work and at the same time enjoy life which was 'to understand what life is all about in a human rather than a German way.' (XII, 451) It was therefore not surprising that he took a very favourable view of the English middle class as a counterbalance to the aristocracy in English life and hoped that, should the aristocracy disappear, the mass of the people would then provide a substitute counterbalance. Contrary to what his 'German friend', Michel Bakunin, might think about the need to abolish the middle class, Belinskii did not know a state which could flourish without its middle class. Industry, he admitted, was a source of great evil, but it was also a source of great benefits to society as a whole. An even greater evil, though, uniting all nations of the world in hatred of it, was Jewish commercialism.

Such thoughts, replete with their bigotry, lack of system and inconsistency, were merely items in a private correspondence which achieved a kind of epilogue in his last letter to Annenkov, dictated from his sick bed in February 1848. Apart from expressing guarded approval of Turgenev's Sketches and disillusionment with Dostoevskii's latest works such as 'The Landlady' (Khoziaika), he reiterated his Westernist views and his personal convictions in the clearest terms. Voltaire remained his hero above all, just as Michel Bakunin, his 'believing friend', remained as misguided as ever in his assessment of the peasantry and of Russia's future. Here was the final echo from the discussions in Paris:

'... my believing friend and our Slavophiles have been an enormous help to me in throwing off any mystical belief in the people. Where and when have the people ever liberated themselves? Everything has always been done through individual personalities. When, in disputing with you about the bourgeoisie, I used to call you a conservative, I was being a 
complete idiot and you were being the intelligent one. The entire future of France is in the hands of the bourgeoisie, any progress is dependent on it alone, and the people can merely play from time to time a role of passive assistance. When I said in the presence of my believing friend that what Russia needed was a new Peter the Great, he fell upon my idea as if it were a heresy, saying that the people must do everything for themselves. What a naive, arcadian idea! After that, why not advocate the idea that wolves living in the Russian forests might unite into a well-ordered state, set up first of all an absolute monarchy, then a constitutional one and finally become a republic?... My believing friend went on to try to prove to me that, God willing, Russia should be saved from having a bourgeoisie. But it's now abundantly clear that the inner process of civil growth in Russia will only begin from the moment the Russian nobility becomes a bourgeoisie.' (XII, 467-8)

Whatever truth there may be in prophecy, Belinskii's vision of future progress was to be a lot more plausible than Bakunin's. But progress in his terms had a priority quite other than Bakunin's anarchism or Herzen's agrarian socialism, even if designed to cultivate a likeminded climate of social and political awareness. Belinskii was ever the literary critic and though these thoughts of his as expressed in his private correspondence may shed an oblique light on his state of mind, his final, most authoritative - if sometimes ambiguous - pronouncements were programmatic in another sense. They were his ultimate judgements on the future of Russian literature.

His 'View of Russian literature for 1847' was published in The Contemporary in two parts, the first in January 1848 and the second in March. The first part contained the programme and began with the idea of social progress as inherently organic, as a product of a history, that is to say, which presupposed a sequential growth. Such progress could be traced in Russian literature from the beginning of the nineteenth century. It had become particularly rapid in recent years and reached its peak with the 'natural school'. Belinskii sought to justify this claim by identifying a twofold lineage of idealism and naturalism which culminated in the work of Pushkin and his Eugene Onegin.

If Pushkin's 'novel in verse' had idealised the landowning ethos, the prose novel, on the other hand, owed its unique place to Gogol's special genius for depicting Russian life in all its truthfulness. In asserting this, Belinskii was largely repeating what he had already claimed several times 
before, in regard both to the novel as a genre and to Gogol's uniqueness, but implicit in the claim, now more than ever obvious, was the need for a democratisation of literature in the sense of greater emphasis on depicting the masses and ordinary people rather than ideal figures. Gogol's great service had been performed in this very sphere. By reproducing reality in all its truthfulness, by emphasising the negativity (otritsanie) of Russian life, he had concentrated on types and the ideal was to be understood in his case not as a decoration (and therefore false) but as 'the relationships in which the author sets his created types consistent with the idea which he wants to develop in his work.' (X, 294-5)

Exactly what Belinskii meant by this did not receive immediate elucidation. The praise lavished on Gogol in succeeding paragraphs suggested a degree of covert apologetics for his notorious Letter while also reflecting in part his on-going polemics with the Slavophiles over the theoretical issue of moral priorities in the portrayal of character. Gogol's uniqueness in this respect was once more endorsed. The 'natural school' could therefore be defined by declaring that 'the close approximation of the figures depicted by it to their models in reality possibly does not comprise its whole purpose, but is its primary objective, without fulfilment of which a work can have nothing good in it,' (X, 297) a burdensome objective, as Belinskii recognised, which could only be achieved by a writer with talent. He then went on to parody elitist literature and to advocate an anti-aristocratic concern for all conditions of humanity by asserting once more his Christian humanism: 'The saviour of the human race came into the world for all men; he called upon not the clever and well-educated but fishermen of simple mind and heart to be "fishers of men" and he sought not the rich and contented but the poor, the suffering and the fallen to comfort some and encourage and fortify others.' (X, 301) Social charity on such a Christian model, he asked somewhat rhetorically, was it not, in the highest sense, a joyous phenomenon of the most recent civilisation, of intellectual success, of enlightenment, of education? And literature, in mirroring society, had done much to promote this change of social attitude.

This raised, of course, the question of the purposes of art. Could there be pure art or did art serve a social purpose? The answer was simple: pure art did not exist per se and had never been more than an ideal expressed in the extreme form of an art that was didactic, instructive, cold, dry and dead, whose works amounted to no more than rhetorical exercises on given themes. Nevertheless, Belinskii went on: 'Without any doubt, art must be first of all art and only afterwards can it be an expression of the spirit and direction of society in a given epoch.' $(X, 303)$ He recognised that the issue was vexed, so that despite the strictures placed on art he did 
not waver in asserting its primacy in evaluating literature but was always conscious of the apparently competing claims of reason and intellect, on the one hand, and creative imagination, on the other. In an interesting passage he debated the issue without labouring his points too much:

'People say that mind and reason are needed for science, imagination for art, and they then think the matter is settled and done with. But doesn't art also need mind and reason? Can a scientist get by without using his imagination? Not true! The truth is that in art imagination plays the most active and pre-eminent role and in science the mind and reason. There are, of course, works of poetry in which one can see nothing save strong and brilliant imagination; but that is by no means a general rule in artistic works. In the works of Shakespeare one doesn't know which to marvel at more - the wealth of creative imagination or the wealth of all-embracing intellect. There are species of scholarship which not only do not demand imagination but can be damaged by it; but one cannot say this about scholarship in general. Art is the reproduction of reality, a repeated or as it were recreated world: can it be some kind of single reality, isolated from all external influences? Can the poet not be reflected in his work as man, as a character, as human nature - in a word, as a personality? It goes without saying that the answer is No! because the very capacity for depicting the phenomena of reality without any relationship to oneself must also be an expression of the nature of the poet. But this capacity also has its limits. The personality of Shakespeare is always discernible through his works although it seems he is just as indifferent to the world he depicts as is the fate that rescues or dooms his heroes.' $(\mathrm{X}, 305)$

Though the notion of enclosedness (zamknutost') raised its head here for the last time in the definition of art as the reproduction of reality in the shape of 'a repeated or as it were recreated world,' Belinskii placed all his authority behind the inevitable relationship between art and social reality, between the poet and his world, with the ensuing important proviso that 'a poet must not express the particular and accidental but the general and necessary which gives colour and sense to his entire epoch.' $(\mathrm{X}, 306)$ In this he was to be guided above all by his instinct, 'a dark, unconscious feeling,' as he put it, 'which often comprises the entire strength of his genius' (Ibid.); and in asserting this Belinskii was hardly offering a very convincing justification of his case, though he evidently had in mind the example of Gogol who had attempted to rationalise his genius and suffered in consequence. It was to Belinskii's credit that, despite arguing so cogently for a 'progressive' literature, he never denied that priority had to be given to the instinctive character of genius in creating literature. Again Shakespeare was quoted as an example: 
'That Shakespeare was a very great creative genius, a poet above all, cannot be doubted; but he is always likely to be poorly understood by those who, because of his poetry, cannot see the rich content of his work, the inexhaustible source of lessons and facts in it for the psychologist, the philosopher, the historian, the statesman and so on. Shakespeare conveys everything through his poetry, but what he conveys is far from belonging only in the sphere of poetry. In general the character of today's art involves a balance of the importance of content over the importance of form, whereas the character of ancient art involved a balance between content and form.' (X, 309-10)

Although this smacked of special pleading, it was in keeping with the main thrust of his argument, which was that art should not be denied the right to serve social interests. That would mean not raising it but lowering it because it would mean depriving it of its very life force, which was ideas. Pure art in the sense of an art without ideas had never existed, he claimed. Both the philosopher speaking in syllogisms and the poet speaking in images and pictures were equally necessary to society, yet talent remained an essential prerequisite, no matter how properly 'tendentious' the subject-matter might be. In this respect he was adamant. It was a claim that went to the very heart of the importance which he attached to 'personality' and the intuitive sources of art; and one suspects that ever in his mind was the example of Gogol:

"The magic little word "tendentiousness" [napravlenie] nowadays attracts many people; they think it is all that matters and do not understand that, in the sphere of art, firstly, no tendentiousness matters a jot without talent and, secondly, the tendentiousness must be not only in the head but primarily in the heart, in the blood of the writer, must be first of all feeling and instinct and only afterwards what may be called conscious thought, that it is as necessary for this tendentiousness to be born as it is for art itself. An idea, whether read about or heard and understood as it should be but not experienced through one's own nature, not endowed with the imprint of one's own personality, is dead capital not only for poetic but for any kind of literary activity. No matter how carefully you copy from nature, no matter how much you spice your copies with ready-made ideas and well-intentioned "tendencies", if you have no poetic talent your copies will not remind anyone of the originals and your ideas and your tendentiousness will remain so many rhetorical commonplaces.' (X, 312)

As a thorn in the side of socialist realism and all forms of political tendentiousness in art, this passage obviously had its significance. In the context of Belinskii's argument it was related to his on-going defence of the 'natural school' as an indigenous Russian phenomenon. In so many 
words this implied that Russian literature had finally found its way. There was no need, of course, to exaggerate its successes; equally there was no need to regard it as unduly influenced by French models. Russian literature of the 'natural school' exemplified by and large what Belinskii defined as 'progress', meaning in his view a striving towards portrayal of the actual, the real, the truthful and rejection of its opposite, which was the fantastic, the spectral. He could claim, therefore, at the end of his life and in his final critical work that Russian literature now existed in its own right, something he had been unable to claim in his first work, his Literary Reveries. The emphasis on reality as the touchstone of truth in art was blinkered after its fashion and inimical above all to poetry and all forms of imaginative writing, despite Belinskii's best intentions. Russian literature was nevertheless evolving towards prose.

'The novel and short story have now become the head of all other genres of writing' $(X, 315)$ was the opening declaration of the second part of his review, and it echoed the statement made thirteen years before in his first signed review, devoted to Gogol's Arabesques and Mirgorod. At that time he could not make substantial claims for the Russian novel and short story. Now, on his sick bed, dictating the second part of his review to his wife, he was able to claim for them the potential of greater freedom for the writer. They posed the challenge of the need for creative imagination along with verisimilitude, particularly in such genres as the historical novel or literary memoir, and very pertinent to this issue was the first work examined, Herzen's novel Who is Guilty?

It elicited praise less as a novel than as a series of biographies which were 'masterfully written and cleverly combined externally into a single whole by an idea which the author had not succeeded in developing poetically.' (X, 322-3) As a judgement this was irrefutable. Belinskii did not find the hero, Bel'tov, convincing, nor was he more than lukewarm about the other figures, but the idea of the work - the exploration of the meaning of humanism and true human feeling (Humanitaet) - received ample endorsement for its relevance to the issue of superfluity and human dignity in Russian society. Herzen, praised as a 'poet of humanitarianism' (gumannost'), was more of an intellectual or philosopher than a creative writer or poet in Belinskii's meaning of the term. In this he offered a complete contrast to Goncharov, whose first novel An Ordinary Story received an extensive, if discursive, review for being exclusively the work of a poet, an artist.

In fact, as Belinskii went on to demonstrate, Goncharov's novel was more to his taste than Herzen's. It was more objective in its treatment of human relationships, more sensitive in its depiction of the young Aduev's faltering first steps on the path of love and self-discovery and chiefly 
notable for the astonishingly well-sustained portrayal of Aduev's uncle, Petr Ivanych. Digressions on the nature of love made the review somewhat unfocussed and led perhaps to an underestimation of the irony of the novel's epilogue. It received, though, the final accolade of being 'one of the remarkable works of Russian literature' with special tribute paid to its 'pure, correct, easy, unconstrained, flowing language.' Not 'a printed book, but an improvisation from life (zhivaia improvizatsiia),' (X, 344) as Belinskii put it, the most remarkable aspect of the novel was the dialogue in which Goncharov could so easily have obtruded as a kind of raisonneur but deliberately refrained from doing so.

The remainder of the review was devoted to thumbnail estimates of other works which had appeared during the past year. Several of the early pieces from Turgenev's Sketches from a Hunter's Album were praised. He was commended for his 'gift of observation, his ability rapidly and faithfully to comprehend and evaluate every phenomenon and instinctively discern its causes and consequences...' (X, 346) and mention had also to be made of his unusual mastery in painting pictures of Russian nature: 'He loves nature not as a dilettante but as an artist and therefore never strives to paint it only in its poetic aspects but takes it as he finds it. His pictures are always true to life and you can always see in them our native Russian natural scene...' (X, 346) Like the Sketches devoted to peasant types, Grigorovich's 'The Village' and 'Anton Goremyka' were instances of the 'democratisation' of literature which Belinskii favoured. He also found features to approve in the work of Druzhinin (Polin'ka Saks) and Dal'. As for Dostoevskii's most recent work, 'The Landlady', he would scarcely have bothered to mention it had it not been for the author's name. He was so disgusted with it he could do little more than exclaim at its strangeness and incomprehensibility, a verdict which may have had superficial justification but was hardly evidence of critical insight. The plea for tolerance towards others' opinions (expressed at the end of the review overall) should have been heeded by Belinskii himself in appraising a work so obviously out of kilter with his own view of literature.

\section{$* * *$}

But he was in a hurry. Dostoevskii himself supplied a glimpse of Belinskii towards the end, describing him as 'the most hurried man in all of Russia." 11 They met only once, it seems, in the last year of Belinskii's life, probably in

11 From his The Diary of a Writer for 1873. F.M. Dostoevskii, Pss., Vol. 21, Leningrad, 1980, p. 12. The ensuing quotes are from this source. 
the autumn of 1847 , while the critic was returning from a visit to the site of the first major St Petersburg railway-station being constructed near his home. 'I often go and see how the work is coming along... My heart expands as I stand there and watch it: at last, I tell myself, we'll have a railway line. You can't imagine how that thought sometimes raises my spirits.'

This was said, Dostoevskii noted, 'fiercely and well: Belinskii was never one to show off. We walked along together. I remember he said to me on the way: "Only when they dig my grave (he knew he had tuberculosis) will they pause a moment and realise who they've lost.",

A touching and endearing moment, beautifully recalled by Dostoevskii, it showed how railways, the novelty of the age, were the true mark of progress and how Belinskii knew he would never live to see that novelty come to pass in his own country, just as, a few months later, he lived just long enough to experience the shortlived triumph of European socialism $^{12}$ in Paris but was saved from seeing its 'final defeat', as Turgenev put it in his Reminiscences. Political ideas, however inchoate, naturally dominated his thinking in the early months of 1848 as a result of the revolutionary events in Paris and of these we may catch a glimpse from the recollections of Aleksandr Berkh. He was a student at the Military Engineering Institute in St Petersburg, and greatly in awe of the Belinskii whom a relative of his (with the initials 'G.P.') ${ }^{13}$ urged him to visit. He apparently delayed for a year, until presumably March 1848, and when he finally plucked up courage to make the visit he found a Belinskii who was virtually housebound through illness - 'a pale, very pale, thin, drawn face, with a pale forehead over which dark locks of hair fell cut in the round like a peasant's' ${ }^{14}$ - and no longer had the strength to write. He had the strength nonetheless to talk, even if with difficulty, and he talked about the February revolution and French politics, aware, it seems, of the likely effect of the revolutionary events on other European countries. What he actually said was not recorded but his teenage audience was so impressed by the two-hour talk that he revisited Belinskii on several subsequent Saturdays. The critic was always alone, to the young Aleksandr's surprise, only disturbed from time to time by Marie entering

12 On May 15, 1848, Auguste Blanqui and Armand Barbes led a group of workers into the Chamber of Deputies in Paris in an effort to replace the political republic with a social one. Belinskii died within a few days of this event.

13 Nechaeva supposes it may have been N.V. Pantusov. V.S. Nechaeva, op. cit., Vol. IV, p. 267.

14 A.M. Berkh, Vosp. sov., p. 572. 
unobtrusively or by little Olga running in from other rooms in what was evidently a spacious apartment. He gave his visitor the impression of having cut himself off from the rest of the world.

It was more likely that the rest of his world had cut itself off from him. Turgenev, Annenkov and Herzen were abroad, experiencing at first hand a Paris in the throes of revolution; Botkin, his closest friend and confidant over so many years, had been treacherously disloyal in working for Kraevskii and apparently could not stomach the sick Belinskii's company. $\mathrm{He}$ was even prepared to denounce him as 'apathetic' and 'written out' and urged Nekrasov not to publish the final review of literature. ${ }^{15}$ Nekrasov, in his turn, was equally ungracious. According to Agrippine, on visiting the sick Belinskii he not only complained that illness was merely an excuse for not writing but threatened him with the likelihood of being forbidden to write anything at all. Marie took such strong exception to his attitude that she exclaimed: 'Aren't you ashamed of tormenting a sick man! Can't you see he's dying?' and showed him the door. ${ }^{16}$ There can be no doubt that Belinskii was treated shabbily.

The Tsarist authorities treated him with similar disrespect and even greater hostility. Nekrasov's threat may have had a truly sinister implication in the sense that, even though the Letter to Gogol was as yet unknown to the authorities, Belinskii had been anonymously denounced to the Third Department in February 1848 as one whose articles contained 'Communistic' ideas. The use of the 'foreign' term 'progress', among others, was seized upon as having a covert political meaning. Belinskii was invited to visit the Third Department but wrote that he was too ill to attend such a meeting and very likely decided at that time to destroy any compromising material in his possession. The Contemporary itself fell under immediate suspicion and was in danger of closure. In other words, Nekrasov's threat was not idle. For the last few weeks of his life Belinskii was under fairly close police surveillance, though he was not actually arrested, nor 'rotted in the Peter and Paul fortress,' the destiny awaiting him had he lived. ${ }^{17}$

His last published work of consequence was an obituary of the famous actor Mochalov who died on 16 March 1848. As an assessment of Mochalov's abilities the dictated encomium offered little that Belinskii had not said in print already. He was praised for his native talent as an actor, driven as it was by inspiration rather than by artistry or training. 'Gifted in

15 V.S. Nechaeva, op. cit., pp. 424-5.

16 A.V. Orlova, Vosp. sov., p. 569.

17 V.S. Nechaeva, op. cit., pp. 433-6. 
the highest degree with a passionate nature, he possessed a voice,' the obituary claimed, 'which was capable of expressing every shade of passion and feeling.' (X, 390) The words seemed to echo all that Belinskii would have wished said about himself, as if the identification with Hamlet and his greatest exponent on the Russian stage at that time were a rounding-off of his own life and achievement, that amalgam of passion and truth which he brought instinctively to his work as a literary critic.

Poverty, though, remained with him to the last. So weakened by tuberculosis that he could not write, he received no income from The Contemporary and was even regarded as in debt to the tune of 6000 roubles. For months the rent was unpaid. The shirts he had bought in Dresden had to be sold. His greatest solace was his little daughter Olga, with whom, so Agrippine recalled, he used to play at being a bear, dressed up in his much-prized dressing-gown brought from Paris. He would roar at her and she would run away, but one time he climbed under a table to frighten her and became so breathless and afflicted by coughing that his wife and sister-in-law were scarcely able to pull him out. ${ }^{18}$

In May, with the coming of warmer weather, he spent much of the time on a divan in the courtyard. He then grew restless and would try to move about from room to room, only to fall down and have to be helped to his feet. 'I never thought I'd live to the point where I'd have to be helped about,' Agrippine reported him as saying. She also provided a moving account of his last moments:

'On the eve of his death, 25 May, he was very quiet and did not cough at all. For several nights in a row my sister had slept badly and had grown terribly tired and about ten o'clock in the evening. went to my room to get some sleep. I remained in the bedroom, directly facing him in the bed. I picked up a book and gave the impression of reading but kept on glancing at him. He lay there quietly, not coughing, saying nothing, but staring at me with such enormous eyes. I did not know where to turn from such staring looks and yet I had to appear calm. He frequently asked for a drink and asked what the time was and would try to reach the edge of the bed. I put a cushion under the mattress to stop him from falling. At first he drank from his glass, then straight from the carafe, and drank so much. I grew more and more anxious and he kept on asking what time it was.

'I stayed there until one o'clock in the morning and then he said: "Get my wife!" I ran to get her and she came in and saw he wasn't lying down but sitting up in bed, his hair all on end and such fright in his eyes. "You

18 A.V. Orlova, op. cit., p. 561. Agrippine remembered the dressing-gown as black, not red, as Annenkov reported. 
look as if something's frightened you?" "Of course, I'm frightened! They want to roast me alive!" My sister calmed him by telling him it must have been a dream. She laid him down more comfortably and ran to tell me he was dying. But I had fallen fast asleep and she didn't want to wake me. She went back into the bedroom and saw that Belinskii had raised himself up again. She placed cushions behind his back and supported him with her arm. Unusually loudly but brokenly he began a kind of speech to the Russian people. He talked hurriedly, interspersed with sighs, about genius and honesty. Suddenly, with inexpressible sadness and in a sick man's wail he said: "They don't understand me, they don't understand me at all! It doesn't matter. They don't understand me now, but they will! Do you understand me?" "Of course I do." "Well, you explain it to them and the children." And his speech became quieter and fainter. My sister laid him back. He still went on talking. Suddenly his daughter started crying and he heard her and said: "Poor child, she's been left all alone, all alone!" "No, she's not alone - my sister's with her." And as soon as I had comforted her, I at once fell asleep again. Finally, at six o'clock in the morning of 26 May, he died quietly. My sister stayed with him by herself all the time. He died just short of his thirty-eighth birthday.' ${ }^{19}$

The funeral took place three days later and was attended by about twenty mourners, mostly the customary ragtag and bobtail at a pauper's burial. The only friend to come to the aid of the bereaved family was Panaev who provided financial help for a few months. Ironically it was he who had first accompanied Belinskii to St Petersburg and it was he who followed him to his last resting place.

The young Aleksandr Berkh called by some time afterwards on a warm sunny day and, finding every sign that the family was moving out, supposed that Belinskii had already left for the summer dacha, only to be told matter-of-factly by Marie that he had indeed already left and would not be coming back. The news of Belinskii's death came as a great shock to the teenage student. He was later to make a distinguished military career for himself during the defence of Sevastopol' in the Crimean War. As he confessed in his memoir, his attachment to Belinskii in the weeks before his death had amounted to an adoration and love which his shyness had prevented him from admitting. ${ }^{20}$

Some money was scraped together to mark Belinskii's grave in the Volkov cemetery with a headstone. Over the years it became so neglected

19 Ibid., pp. 562-3. In fact, if the date of his birth was 30 May 1811, he must have died within four days of his thirty-seventh birthday.

20 A.M. Berkh, op. cit., pp. 575-6. 
that Chernyshevskii, for instance, had difficulty finding it at the time of Dobroliubov's death in 1861 when he endeavoured to fulfil the deceased's wish to be buried beside his 'teacher' and had to rely on a stranger's remark about a 'great man' being buried somewhere there to trace the exact spot. Meanwhile, Marie returned to Moscow with Agrippine and little Olga and Belinskii's dog. She was pregnant for a third time (the baby, a girl, died in November 1848 shortly after birth) and necessity obliged her to take a poorly-paid job as a linen-keeper in the Alexandrovskii Institute where Agrippine resumed her teaching duties. The family lived by all accounts a threadbare existence for many years with no financial help from any of Belinskii's former friends. Finally, with the publication of his works, Marie received 14,000 roubles $^{21}$ which she used as a dowry for Olga on her marriage. The family moved to Corfu in Greece. It was from here, in 1891, that Agrippine wrote her brief but revealing account of her life in the Belinskii household.

In 1866 Marie could afford to erect a much finer memorial to her late husband in the Volkov cemetery. It became further marked in 1883 when Turgenev's wish to be buried beside him led to a serious disagreement between his widow and the graves' commission. The commission proposed to disinter Belinskii's remains and move them to the section of the cemetery reserved for members of the nobility, so that Turgenev's wish might be fulfilled. Marie objected. A compromise was therefore reached by the commission's appropriation of the area of the cemetery between Belinskii's grave and the nearest possible point in the area reserved for nobility burials where Turgenev could be buried (amounting to some ten burial plots). ${ }^{22}$

In this way - though at a respectful distance - Belinskii and Turgenev were united in death. In life Turgenev, equally distanced by privilege and age, had not always been the most reliable of friends, but in his maturity, as a famous novelist and the first Russian writer to achieve a European reputation, he recognised his indebtedness to Belinskii and commemorated the debt by deliberately dedicating his most controversial work to him and, at the end of the 1860 s, forever preserving his memory in the best memoir he ever wrote. What he was acknowledging with hindsight was Belinskii's contribution to the genesis of Russian nineteenth-

21 The money came from the 12-volume collected edition of his works published in 1859-62 with the help of A.D. Galakhov, under the editorship of N. Kh. Ketcher, M.K. Soldatenkov and N.M. Shchepkin.

22 V.A. Manuilov and G.P. Semenova, Belinskii v Peterburge, Leningrad, 1979, p. 327. 
century literature as we now know it. The acknowledgement also included tacit recognition of the debt owed by Russian literature and society to the critic and personality known as 'ferocious Vissarion.' For far too many years official suppression of his name had led to neglect of his reputation as of his grave, both of which were only remembered and revisited, like the grave of Turgenev's hero, Bazarov, by those who had loved him most. 



\section{Conclusion}

The dedication of Turgenev's masterpiece Fathers and Sons (Ottsy $i$ deti, 1862) 'To the memory of Vissarion Grigor'evich Belinskii' has proved the most lasting memorial to his name. It was a dedication made both as a token of friendship and in protest at the way his name had been suppressed immediately after his death. Following the Crimean War, in the ensuing period of reform, both his reputation and his dream of liberating the Russian people from serfdom became issues of public debate prior to the Emancipation Act of 1861.

Times, of course, had changed. Turgenev's generation of the intelligentsia had been superseded. No longer content to be 'gradualist' or 'liberal' in their demand for change, as the generation of the 'fathers' had been, the young raznochintsy' or 'new men', those whom Turgenev branded as the 'sons' or 'children', were more radical and revolutionary. In this respect, Belinskii was their direct forerunner. Turgenev intimated as much by implying a resemblance between his nihilist hero, Bazarov, and the 'furious Vissarion' through his dedication. Manifestly of an older generation though not exactly one of the 'fathers', Belinskii had made it his public duty throughout his career as a critic to proclaim the need for the type of liberated individual exemplified so masterfully in the character of Bazarov and his own boldly assertive moral nihilism, if not based in the natural sciences, had about it all the anti-establishment passion which characterised the revolutionism of the 'new men' of the 1860 s.

This was the Belinskii to whom Turgenev dedicated his novel. This was also the Belinskii who 'had died in time', as Turgenev put it in his

1 Plural form of raznochinets, meaning those of multi-rank background (a reference to the 14 ranks of the government service created by Peter the Great) who were children of civil servants, priests, doctors, etc. and not principally of peasant origin. 
Reminiscences. He had died, in fact, before disillusionment with the events in Paris stifled the euphoria of the revolution's beginning. Significantly, published as they were just over twenty years after Belinskii's death, Turgenev's Reminiscences formed part of a series of literary and other reminiscences containing autobiographical fragments devoted to his experiences during the 1848 revolution. ${ }^{2}$ Belinskii's own views may not have been revolutionary, but they were clearly sympathetic to degrees of radical change which the hidebound autocracy of Tsar Nicholas I could easily brand as dissident in the extreme. Such views and much lesser instances of them were persecuted accordingly, as Dostoevskii was persecuted, imprisoned, subjected to mock execution, sentenced to penal servitude and exile in Siberia for reading aloud the Letter to Gogol, and Herzen was driven abroad into lifelong exile for simply wishing to think freely, and Turgenev himself was imprisoned and later confined to Spasskoe-Lutovinovo for his obituary on Gogol (though the real pretext was the publication of a separate edition of his Sketches from a Hunter's Album in 1852). Belinskii died before he could be persecuted, but the revolutionary context and intent of his ideas clearly justified Turgenev in using his Reminiscences to set his recollections of Belinskii beside his recollections of revolutionary Paris in 1848.

He was also justified in his initial claim that Belinskii was, as he put it, 'what I permit myself to call a central nature; with his entire being he stood close to the heart of his people and embodied it completely, both its good and its bad sides.' ${ }^{3}$ The centrality of Belinskii's nature in this context was both social, in the sense of being a raznochinets, of neither peasant nor nobility origin, and psychological or intellectual, in the sense that, largely self-educated as he was, he had the freedom to choose his own ideas and remain uncommitted to received opinion or the need to 'serve' in an official sense while still being firmly rooted in his native heritage. What Turgenev also stressed, and perhaps unfairly, was Belinskii's ignorance of matters outside the sphere of Russian literature. Within that sphere, however, he was unrivalled:

2 Published as Literaturnie $i$ zhiteiskie vospominaniia, 1869 (commonly translated as Literary Reminiscences with the addition of 'Autobiographical Fragments' to convey the idea of zhiteiskie, e.g. David Magarshack's Turgenev's Literary Reminiscences, with an essay by Edmund Wilson, London, Faber and Faber, 1959; referred to in this study simply as Reminiscences.)

3 Vosp. sov., p. 489. 
'Belinskii undoubtedly possessed the principal qualities of a great critic; and if, in the matter of knowledge, he had to borrow from friends and accept their words on faith, in the matter of criticism he had no need to ask anything of anyone. On the contrary, others always yielded to him; the initiative was constantly with him. The esthetic sense in his case was almost faultless; his insight always penetrated deeply and never became hazy. Belinskii was not deceived by appearances or circumstances and did not submit to influences and trends; he used instantly to recognise what was beautiful, what was ugly, what was true and what was false, and would deliver his judgement with courageous boldness - would deliver it fully, without hesitation, passionately and strongly, with all the headlong certainty of conviction. Anyone who has witnessed the critical mistakes to which even remarkable minds have been prone ${ }^{4} .$. cannot but feel respect for the acute judgement, sure taste and instinct of Belinskii and for his ability to "read between the lines." 5

Yet Belinskii knew, as Turgenev goes on to point out, that he had to confine his publicly expressed opinions to literary matters in view of the censorship under Nicholas I and the prevailing official climate. He was also - and here Turgenev must seem less than specific in his prognosis though remarkably farsighted for all that - very clear about seeing and understanding that in the development of every nation an epoch of literature preceded other epochs and that there can be no progress until that epoch has been lived through and fully experienced. Criticism, therefore, in the sense of negation of falsehood and lies, must initially concern itself with analysing literary phenomena - and this was exactly what Belinskii saw as his vocation. Although his political and social convictions were very strongly held, they remained, so Turgenev believed, in the sphere of instinctive sympathies and antipathies and Belinskii knew he had no means, nor intention, of implementing them in reality. Despite that, 'as a literary critic he was precisely what the English call "the right man in the right place".'6

4 The reference at this point in Turgenev's text is to Pushkin's exaggerated description of the mediocre tragedy Marfa Posadnitsa as 'Shakespearean'.

5 Vosp. sov., pp. 490-1.

6 Ibid., p. 493. Turgenev's English was 'the right man on the right place.' Interestingly, in this same context (p. 494), Turgenev took Pisarev to task for his negative attitude to Pushkin, an attitude which was by implication equally hostile to Belinskii. 
$\mathrm{He}$ was the right man in the right place, in Turgenev's estimate, because he was an idealist. 'Belinskii,' he went on, 'was as much an idealist as he was a negative critic (otritsatel'); he criticised negatively in the name of an ideal. This ideal was of a very definite and uniform kind, although it was called and is still called by different names: science, progress, humanitarianism, civilisation, finally the West. Unsympathetic but well-meaning people even use the word: revolution. It's not a matter of what it is called but of its substance, which is so clear and beyond doubt that there is no need to dwell on it: misunderstandings are pointless here. Belinskii devoted all of himself to service of this ideal; in all his sympathies and in all his activity he belonged to the camp of "Westernists" (zapadnikov) as their opponents called them. He was a Westernist not only because he recognised the superiority of western knowledge, western art and western social structures, but because he was deeply convinced of the need for Russia to acquire everything that had been worked out by the West to ensure the development of its own strength and its own significance. He believed that we had no other way to salvation than by following the path shown us by Peter the Great, against whom the Slavophiles were then hurling their choicest thunderbolts. ${ }^{7}$

Turgenev was of course defending his own principles as well as Belinskii's in this declaration of the latter's pro-Western idealism. He was on the side of the angels in doing so, since the leading spokesmen for the generation of the 'sons', Chernyshevskii and Dobroliubov, were equally keen to acknowledge Belinskii as their forerunner and mentor, but if his Westernist sympathies were no impediment to Belinskii's popularity in the eyes of later generations, his reputation as 'the right man in the right place' in terms of his literary criticism tended gradually to take second place to his image as a seeker after truth, an ideological father of the Russian intelligentsia (vlastitel' dum), who struggled year after year to achieve an independent intellectual position for himself. This aspect of Belinskii's reputation cast in the shade both his originality as a literary critic and his lifelong personal struggle for love and good health.

Plekhanov's interpretation of Belinskii, very authoritative in its time and crucial for later Soviet asessments, stressed, firstly, a periodisation in the critic's evolution based almost wholly on the extent to which he was successively influenced by Fichte, Hegel and Feuerbach and, secondly,

7 Ibid., pp. 499-500. 
offered what was claimed to be the critic's 'esthetic codex' ${ }^{8}$ Marxist and scholarly though he was, Plekhanov appeared over-emphatic in his concern to identify Belinskii as a dialectician rather than as a literary critic and, by his reductionist codex of laws, to turn the lifelong struggle for a national literature into what came to be recognised as a formula for 'realism', a term which Belinskii himself of course never used. No Soviet interpretation of value could afford to ignore Plekhanov, even if it became a sign of Marx-Engels-Lenin-Stalinist legitimacy to dispute or deride his approach. ${ }^{9}$ What was of course also overlooked in such interpretations was the personal struggle.

It is arguable, for example, that Belinskii's view of literature's role was as much influenced by moments in his personal life - the loveletters to his future wife in late 1843 were one instance - as by his rejection of Hegel or his adoption of the basic tenets of Utopian Socialism. The ideas, whether Schellingian in relation to his first work, Literary Reveries, or Feuerbachian in relation to his quasi-materialist interpretation of 'personality' in his 'View of Russian literature for 1846' ('Mind is a human being in a body or - better - a human being through a body, in short, a personality') were always to a greater or lesser extent imported into his articles as foreign matter, highlighted, as it were, to emphasise

8 Plekhanov defined the codex as follows: 'The first law of this codex specifies that a poet must show, not prove, must think in images, not in syllogisms. This law flows from a definition of poetry according to which it is an unpremeditated consciousness of the truth or a thinking in images.

'But if the subject of poetry is truth, then truthfulness is the first condition of artistic creation and beauty is truth and simplicity. A poet must depict life as it is, without enhancement or distortion. This is the second law of Belinskii's esthetic codex.

'The sense of his third law is that the idea lying at the source of a work of art must be a concrete idea that encompasses the whole subject and not only one aspect of it.

'The fourth law is that the form of a work of art must correspond to its idea and the idea to the form.

'Finally, unity of form must correspond to unity of thought. This means that all parts of a work of art musi comprise a harmonious whole. This is the fifth and, if we are not mistaken, the last basic law of Belinskii's esthetic codex.' G.V. Plekhanov, 'Vissarion Grigor'evich Belinskii (1800-1848)', Istoriia russkoi literatury XIX veka, pod red. D.N. Ovsianiko-Kulikovskii, Vol. 2, M. 1909, p. 259. Plekhanov's more detailed studies of Belinskii amplify but do not substantially alter this codex.

9 For an extremely valuable digest of competing attitudes to Belinskii's reputation, see Victor Terras, Belinskij and Russian Literary Criticism: The Heritage of Organic Aesthetics, University of Wisconsin, 1974, especially chapter 7: 'Belinskij's Heritage'. 
their novelty and importance. They manifested, of course, his Bazarovlike, nihilistic tendency never to accept any authority on faith and implicitly to challenge conformist native thinking by introducing new - that is to say, European - ideas. Indeed, this form of 'enlightenment' was fundamental to the purposes of the Russian intelligentsia. Belinskii largely set the tone in this respect, along with his question-and-answer, catechetic style, in which the question usually assumed greater importance than the answer.

Victor Terras has helped to define Belinskii's achievement in the following way:

'He succeeded in integrating Russian literature into the historical development of the Russian nation as he saw it, and in presenting the major works of Russian literature as organic products of the Russian national spirit as well as of the Zeitgeist. Even more important, he was instrumental in creating a relationship of regular and conscious mutual feedback between Russian literature and Russian sociopolitical thought.' 10

There is no disputing that this was true of Belinskii's role as a literary critic, but one must necessarily add that throughout his career as a critic he was engaged in a struggle to make Russian literature pass muster as a branch of European writing, to match the standards of Europe in terms of excellence as a literature reflecting the social and psychological realities of its time. For that reason he concentrated on the best — on Pushkin, that is to say, as the only Russian poet to compare with the European masters, on Gogol as the only Russian prose writer to rival European equivalents, on Lermontov as a master of portraiture in the European manner, and if he was never exactly specific in making large claims for them, or altered his opinion as to their precise merits over time, he always insisted that, just as Russian literature, in his view, began with Peter the Great's orientation of Russia towards the West, it should ultimately be judged by European standards and enjoy a rightful place in the company of other European literatures.

This insistence on European standards of comparison - and every one of Belinskii's major or programmatic statements in his annual reviews of literature subsumed a European context - was of vital consequence for the future development of Russian literature both as a supposedly organic, national phenomenon and as a national literature designed to encompass universal human issues. The fundamentally Christian precepts at the source of Belinskii's beliefs were to be the moral guidelines for this

10 Ibid., p. 213. 
literature. But they were not ready-made. They were parts of an ongoing struggle to be witnessed in the pro and contra of Belinskii's thinking, in the posing of question and answer, in the trial and error of his search for ideas and ideals. Whether through Shakespeare's Hamlet, or such exemplars as Lermontov's Pechorin and Pushkin's achievement, not to mention the enduring image of Peter the Great or the misinterpretation of Hegel, Belinskii's was a lifelong struggle to enlarge his own understanding, to achieve fuller recognition of the moral values guiding human conduct and social relations, all with the aim of developing what he himself regarded as of supreme importance, the notion of individuality, of human personality (lichnost'), the only likely guarantee of progress and social justice. This legacy of his can be said to find its mirror image in the experience of so many intellectually inquiring, self-questioning, morally unsure heroes and heroines of the major Russian fiction of the 1860s and 1870 s, none more so than Dostoevskii's. As a leading Russian commentator has succinctly observed:

'Throughout almost all his literary work Dostoevskii struggled with Belinskii as in the Biblical story Jacob struggled with the Lord.'11

Emphasis, then, on content (though never to the exclusion of artistic form), on ideas, on such prose forms as the novel and short story, on truthfulness in depicting reality, on awareness of the historical and social responsibilities of literature and those responsible for it, and emphasis finally on the morally questing and questioning individual seeking in a Russian context to perceive what could be regarded as truly progressive by universal, meaning basically European, standards - such was the principal emphasis of Belinskii's thinking and literary criticism. Take away the European standard, meaning the certainty that Russia must be rated in terms of the West, and you take away practically all of Belinskii's teaching and influence. Nineteenth-century Russia never did this; it may have disputed the West's priority and primacy; it never seriously disputed that Belinskii was right in his emphasis on the need for Russian literary standards to match those of the West. Twentieth-century Soviet Russia did. Its deliberate repudiation of the West gave rise to a literature deprived of a cultural umbilical cord to its European past and sustained by little except conformity to politically imposed standards and a civic purpose supposedly justified by notions of collectivism. It was a literature devoid of that passionately concerned, nurturing influence which Belinskii's literary criticism, in its Westernism and insistent moral questioning, brought to the literature of nineteenth-century Russia and led to it gaining

11 V. Kirpotin, Dostoevskii i Belinskii, izd. vtoroe, M., 1976, p. 299. 
a leading place among the literatures of the world. In this sense there is no disputing that Belinskii was 'the right man in the right place.'

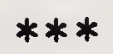

The legacy of Belinskii, the man, and his influence as the 'ferocious Vissarion' were even greater. The fact that he embodied the ideal of the self-made intelligent, privileged only by merit, entitled him to be respected for his views. It gave him the undisputed right to speak for freedom and social justice, to challenge morally and ideologically the prevailing conformities and, finally, to create his own personality, his own form of lichnost', his own independent basis for right conduct in much the same way as he strove to identify and encourage specifically national, Russian qualities in the society and the literature of his time. It was also integral to his passion. According to Herzen, what Belinskii always needed was argument and opposition, for there dwelt beneath his shyness and puny physique the powerful nature of a gladiator:

'Oh, indeed, he was a fighter! He did not know how to sermonise and instruct; what he needed was argument. He did not speak well without objections, without being irritated, but whenever he felt wounded, whenever his dearest convictions were touched upon, whenever the muscles of his face began to quiver and his voice cracked, he was a sight to behold: he would fall on his opponent like a wild beast, he would tear him limb from limb, make him a laughing stock, make him look pathetic, and all the while he would develop his own ideas with extraordinary force and poetic feeling. An argument would very often end in blood, which would gush from his throat; white-faced, breathless, his eyes fixed on his opponent, he would raise a handkerchief to his mouth with shaking hand and stand there, deeply offended, crushed by his own physical weakness. How I loved and pitied him at such moments!'12

No matter how exaggerated this picture may have been, it conveyed an impression shared, for example, by a much less impressionable and more phlegmatic observer, who knew Belinskii for a shorter time than Herzen but no less intimately: Ivan Goncharov. Goncharov's estimate of Belinskii was very perceptive.

'It is understandable,' he wrote, 'that, combining in himself the roles of publicist, esthetic critic and tribune, and being a prophet of imminent new fundamentals of social life, he should inevitably fall sometimes into extremes, into sharp words, into a fever of haste, distractions, 
disillusionments, disagreements, ephemeral sympathies, unjust antipathies and innuendoes - in a word, into a fever of constant struggle without cease and without a backward glance."13

This hectic, hurried Belinskii was of a piece with Goncharov's overall view, but he recognised particularly the rare quality of the man, for as he put it: 'If writers themselves are not encountered at every turn, then critics of Belinskii's powerful sensibility, allied to his strength of mind and giftedness, are even rarer.' ${ }^{14}$ And one aspect of this rarity, which Goncharov appeared to appreciate more than any other of his literary contemporaries, was Belinskii's deep concern for female emancipation and the place of woman in marriage. 'In general, looking at his family life, it would be possible to conclude,' he observed with a bachelor's modest irony, 'that in fact he always recognised the "sanctity" of family ties - he who never liked to recognise the sanctity of anything. ${ }^{\prime} 15$

Few people, even his closest friends, ever penetrated deeper into what was most sacrosanct for Belinskii. He deliberately hid his boyhood from view and such glimpses of autobiography as we have tell us little more than was known to his contemporaries about the 'sanctity' of his private life. At the heart of it, of course, was disease. When exactly he contracted his tuberculosis we have no idea, but presumably it was in childhood. Though perhaps not serious at the start, it must have had an isolating effect and no doubt contributed to the increasing emphasis in his thinking and his literary critical work on the importance of the individual, on the role of lichnost'; for as a recent history of tuberculosis has claimed, it was an illness that encouraged individualism and became associated particularly with the nineteenth-century bourgeoisie. ${ }^{16}$ Belinskii was no "bourgeois' but he was, as Turgenev put it, a central nature within the context of the Russian social hierarchy of his day and reverence for individuals was self-evidently reinforced in his case by the constant presence of illness. Notions of 'sacrifice' and 'atonement', so common in the nineteenth-century view of tuberculosis, were inseparably part of his vision of the way 'personalities' could make their presence felt in ensuring progress.

13 Ibid., pp. 542-3.

14 Ibid., p. 541.

15 Ibid., p. 548.

16 'Illness is an intensely individual experience and reverence for individuals rather than for families, clans or lineages was a bourgeois invention.' Thomas Dormandy, The White Death: A History of Tuberculosis, London, The Hambledon Press, 1999, p. 61. Chapters 6, on 'sacrifice' and 'atonement', and 8 , on the Romantic image, have special relevance to Belinskii's case. 
He lived that kind of life of sacrifice and atonement in the name of literature, but he expressed it at its most obvious and most personal in the love letters to his future wife. This aspect of the Belinskii so often projected as the austere, humourless and forbidding critic, revolutionary democrat and moral teacher has never been studied before in any of the works devoted to him. The passionate man was here at his most passionate. His love for his future wife simultaneously inspired him to write some of his best passages of literary criticism, in his study of Pushkin's lyrics, for instance, or his lines on Tatiana in Eugene Onegin. In his relations with his wife, despite evidence of friction and misunderstandings, he displayed a husband's tolerance which was matched, so far as one can judge, by wifely concern and if it was not exactly a marriage made in heaven it offered a family life that grew mutually warmer the more ill he became.

This aspect of his biography must give depth and perspective to his personality without altering the fact that, as a man, he had an angry, sharp-edged mind, ${ }^{17}$ gifted with particular sensitivity in the understanding of literature and its values, and a personal character which drew gifted people to him as equals, in a spirit of deference and awe. He had blind spots and preferences, was tediously repetitious in restatements of his views, could be prolix and muddled, too grandly magniloquent and histrionic in his purple passages, contradictory and tendentious. He was also never less than sincere, heartfelt, eloquent and robust in his opinions and verdicts, occasionally to the point of achieving vividly memorable judgements. An animal-lover, doting on children, especially his little daughter Olga, fond of flowers and card-playing, he was rigorously self-disciplined in his reading, in pursuing the treadmill of his work and in conducting correspondence with friends or enemies, so that his personal self as revealed in his letters can illuminate the man more thoroughly and truthfully than the public image as enshrined in his critical writings.

Bursting as he was with knowledge and opinions, he always had a publicist's need for a forum. This must partly explain his love of the theatre. He never wrote self-indulgently for himself. Even his letters, however private and confessional, were not designed as diary entries. They needed an addressee. The public voice in his case expressed itself

17 Not all, of course, would agree. Francis B. Randall concluded his Vissarion Belinskii (Oriental Research Partners, Newtonville, 1987) with the confession: 'My mind, after much study, rates Belinskii high, but not with the highest. But the great minds who knew him recognised him as a peer, and I cannot say that I know they were mistaken. This is the ultimate question in judging Belinskii, and who has the arrogance to say the question is not still open?' p. 127. 
initially through the theatre, with his youthful drama Dmitrii Kalinin, nurtured itself on Shakespeare, became in its maturity closely associated with a new realistic Russian theatre whose founding father was his friend, M.S. Shchepkin, and on his deathbed concluded with his obituary to Mochalov, the greatest actor of his age. The theatre as a mirror of human personality and a reflection of life excited and motivated him. It inspired a declamatory note in his writing that resounded through all his most obviously programmatic statements about Russian literature. But because it tended to have the spontaneity of good declamation, Belinskii's style as a critic could accommodate many viewpoints and attitudes. It lent itself more to the theory of literature than to literary criticism as such, to generalisations rather than to specifics, which meant that his authority could often be quoted in defence of different arguments. So voluminous and wide-ranging was the catholicity of his preferences and enmities, his reputation could easily be adapted to seem orthodox to some, haphazard and liberal to others, either ultra-revolutionary and blinkered or admirably balanced and inspiringly erudite.

What has remained as testimony to his personal influence - an influence exercised in its most effective form over a period of little more than seven years (between 1840, say, and 1847) - was the emergence, scarcely a decade or more after his death, in the immediate wake of the Crimean War, of a national literature recognisably Russian, recognisably a match for its European counterparts in the genre of the novel, with a role and a programme recognisably superior in its effects upon society and in its understanding of human nature to those prevailing in European cultures. No literary critic in a major European culture of the nineteenth century rivalled him in this respect. His circumstances were of course Russian and constrained by official censorship, just as he was of provincial background, with none of the initial advantages of his more privileged contemporaries and unable to acquaint himself with Europe directly until the last year of his life, but he saw from the very beginning that Russia needed the West quite as much as it needed to acquire 'enlightenment' as a prerequisite of a national culture. This meant awareness of Shakespeare, for instance, and Voltaire and the classical heritage, among many other things, and he, Vissarion Belinskii, could act as a channel for such influences to enter Russian life.

It was an influence, both personal and public, that was two-way and ambiguous. It aimed to foster a national literature and to create an intellectual ambience in which Russian literature could flourish. The ambience was Europe-orientated, though never uncritically, but with the clear implication that Russia, its public and its society, needed to learn, as he, 
Belinskii, sought to learn through an awareness of European literatures and ideas. Out of his example grew a Russian literature and a Russian intelligentsia. It is arguable that without Belinskii's influence the literature would not have been so intelligent or the intelligentsia so literary, but this was less important than his sense of being enragé, outraged, essentially in denial, unprepared to accept unquestioningly, at the core of which, as Isaiah Berlin has put it, was 'crudeness, and a self-conscious, rough, sometimes aggressive tone in his writing. This tone enters Russian literature, never to leave it.' ${ }^{18}$ To this extent, Belinskii entered Russian literature, never to leave it.

His greatest legacy was opposition to injustice. He was at his most passionate when confronted by degrees of injustice of every kind, from the manifest indignity of buying and selling human beings sanctioned by serfdom to the innumerable slights to human dignity sanctioned by hierarchy, convention and prejudice. His vision of Christ as revolutionary, of Christian humanism as a liberating social ideal, was inseparably part of his opposition to injustice, but it was a current that ran deeply through his thinking and was only realised partly in his struggle to define what he meant by 'personality'and 'progress'. The legacy of his outraged tone and passionate example was always there as an uneasy, discordant, provocative summons to confront every injustice, even the very injustice ultimately done to his name, his reputation, his achievement and to Russian literature through the association with Stalin's patronymic, Vissarionovich. To have outlasted that spurious adulation has meant that justice can finally be done to the Vissarion Belinskii who struggled all his life to make Russian literature true to his vision of it as the only sure means of achieving justice in Russian society.

18 Isaiah Berlin, Russian Thinkers, London, 1978, p.176. 


\section{Explanatory List of Little-Known Russian Personalities}

Letters after each entry, where appropriate, indicate the source of further information available in the following works:

Derek Offord, Portraits of Early Russian Liberals, Cambridge University Press, 1985 (referred to as P).

Handbook of Russian Literature, edited by Victor Terras, Yale University Press, 1985 (referred to as H).

Reference Guide to Russian Literature, edited by Neil Cornwell, Fitzroy Dearborn, London-Chicago, 1998 (referred to as R).

Aksakov, I.S. (1823-86). Son of S.T. Aksakov and brother of K. Aksakov. Slavophile journalist. Became prominent as leading figure of Slavophile ideology in 1860 s and 1870 s. (H)

Annenkov, P.V. (1812-87). Critic and memoirist; friend of Belinskii (post-1843), Turgenev, Herzen. Author of famous memoir 'The Remarkable Decade' (1880) devoted to ideas and personalities in the $1840 \mathrm{~s}$. Editor of first scholarly edition of Pushkin's works. (P)

Bakunin, M.A. (1814-76). Known to Belinskii as 'Michel'. Founder of European Anarchism, political theoretician and activist. Famous for his Revolutionary Catechism. See Studies by E.H. Carr and Aileen Kelly. $(\mathrm{H})$

Baratynskii, E.A. (1800-44). Poet. Outstanding member of so-called Pushkin 'pleiad'. Philosophical and elegiac in content, his poetry was noted for its harmonious, subtle and complex qualities, though he was little appreciated by contemporaries. $(\mathrm{H}, \mathrm{R})$ 
Batiushkov, K.N. (1787-1855). Poet and essayist. Composer of elegiac poems, part-Classical, part-Romantic; considered leading fore-runner of Pushkin. Suffered periodic depression and was committed to an insane asylum (mid-1820s). (R)

Botkin, V.P. (1811-69). Publicist, art and literary critic. Wealthy from birth, an ardent tourist in Europe, author of travelogue letters from Spain (1847-9). Close friend and correspondent of Belinskii, Turgenev, Annenkov. $(\mathrm{P}, \mathrm{H})$

Chaadaev, P.Ia. (1794-1856). Philosopher; religious thinker. Author of famous 'Philosophical Letter' (1836) which condemned Russia's lack of an indigenous culture. Officially declared mad, he wrote 'The Apology of a Madman' (1837) but was effectively silenced thereafter. $(\mathrm{H})$

Chernyshevskii, N.G. (1828-89). Publicist and novelist. Leader of radical younger generation of intelligentsia in post-Crimean War period. Advocate of Feuerbach, materialism and anthropological principle in philosophy, he perpetuated Belinskii's influence for the 1850s and 1860s. Most famous for his revolutionary novel What is to be Done? (1863). Arrested in 1864 and exiled to Siberia. $(H, R)$

Derzhavin, G.R. (1743-1816). Poet. Celebrated for his odes, notably to Catherine the Great ('Felitsa', 1789), but he always transcended the role of court poet. (H, R)

Dmitriev, I.I. (1760-1837). Poet of Karamzinian 'sentimental' school. (H)

Dobroliubov, N.A. (1836-61). Critic and publicist, famous as 'enfant terrible' of The Contemporary (1858-61) with his seminal review of Goncharov's Oblomov ('What is Oblomovism?' 1859) and articles on the 'dark kingdom' of Ostrovskii's plays. He epitomised radicalism in criticism. $(\mathrm{H})$

Druzhinin, A.V. (1824-64). Novelist, esthetic critic, theoretician of conservatism. Author of Polin'ka Saks (1847). (P, H, R)

Fonvizin, D.I. (1745-92). Playwright. Famous for two comedies, The Brigadier (1768-9) and The Minor (1782). (H, R)

Goncharov, I.A. (1812-91). Novelist and essayist. Most famous for Oblomov (1859), his second novel, portraying its indolent hero afflicted with the disease of 'Oblomovism'. (H, R)

Griboedov, A.S. (1795-1829). Playwright. Famous for his satirical comedy Woe from Wit (1825). (R) 
Grigorovich, D.V. (1822-1900). Writer. Author of the short novels 'The Village' (1846) and 'Anton Goremyka' (1847) about the peasantry, he acquired the status of a literary 'elder' in later life, particularly noted for encouraging Chekhov. (H, R)

Herzen, A.I. (1812-70). Memoirist, novelist, editor and political commentator. Famous for his reminiscences of the Russian intelligentsia in its early years with his Past and Thoughts (Byloe i dumy). Author of the novel Who is Guilty? (1847). In his London exile, leading exponent of Russian socialism and critic of Russian autocracy as editor of The Bell. Became an advocate of agrarian socialism in the $1860 \mathrm{~s}$. (H, R)

Ivanov, D.P. (1812?-81). Son of Belinskii's first cousin, F.S. Ivanova. Educated with Belinskii at Chembar and at Moscow University but on different courses. Their friendship lasted throughout Belinskii's life.

Karamzin, N.M. (1766-1826). Writer. Exponent of 'sentimentalism', most noted for his famous short story 'Poor Liza' (1792); also a travel writer and author of short novels. Later renowned as a historian with his History of the Russian State. $(\mathrm{H}, \mathrm{R})$

Katkov, M.N. (1818-87). Journalist, critic and translator. Became politically conservative in his maturity as editor of the influential journal The Russian Messenger which published some of the most important works of Turgenev, Tolstoi and Dostoevskii. (H)

Kavelin, D.V. (1818-85). Publicist, lawyer and university professor. Became renowned advocate of liberalism. (P)

Ketcher, N. Kh. (1809-86). Doctor and writer. Translator of Shakespeare. In later life he adopted right-wing views. Editor of first edition of Belinskii's works.

Khomiakov, A.S. (1804-60). Poet, theoretician of Slavophilism, inventor. He stressed the importance of sobnornost' ('togetherness') in faith and Christian fellowship. (H)

Kol'tsov, A.V. (1809-42). Poet. Born in Voronezh, where he was forced to work for a despotic father in his cattle-dealing business, he was rarely able to meet other members of the literary world, but with encouragement of Stankevich and Belinskii became famous as a poet who explored the sadness and bitterness of peasant life. $(H, R)$ 
Kraevskii, A.A. (1810-89). Proprietor and editor of Fatherland Annals. Later, post-1852, took over St Petersburg News and enjoyed success and considerable riches as a consequence.

Krylov, I.A. (1769-1844). Fabulist. Renowned for satirical use of animals and their traits to poke fun at human weakness and social inadequacies. Also gained a reputation as a dramatist. $(H, R)$

Lermontov, M. Iu. (1814-51). Poet, dramatist and novelist. Leading poet after Pushkin, Byronic in spirit in earlier works, later enlargd his themes and became more socially engaged. Author of the first true psychological novel $A$ Hero of Our Time. (H, R)

Lomonosov, M.V. (1711-65). Poet. Russia's first scientist of note. Author of odes to Russian sovereigns and instrumental in reforming poetic language and versification. $(H, R)$

Maikov, A.N. (1821-97). Poet. Themes of nature couched in lyrical verse celebrated harmony and joy of living. Steadfastly anti-civic in attitude. (H)

Nadezhdin, N.I. (1804-56). Publicist and academic. Founder of the journal The Telescope (1831), closed after publication of Chaadaev's 'Philosophical Letter'. Exiled for a time to Siberia where he became interested in ethnography. $(\mathrm{H})$

Nekrasov, N.A. (1821-78). Poet and editor. Post-1846 edited The Contemporary. Renowned as greatest poet after Pushkin for the civic themes and realistic manner of his poetry. Achieved widespread fame with his long poems 'Red-Nosed Frost' and 'Who is happy and free in Russia?' (1863-76). (H, R)

Nikitenko, A.V. (1804/5-77). Academic. Of serf background, achieved an education only with great difficulty. For a time a censor. Enjoyed modest fame for his 'Speech on criticism' (1842) and his attempt to write a history of Russian literature (1845).

Panaev, I.I. (1812-62). Journalist. Co-editor of The Contemporary. Wrote mediocre fiction but valuable as a memoirist. $(\mathrm{H})$

Polezhaev, A.I. (1804/5-38). Poet. Incurred enmity of Tsar Nicholas I and was forcibly conscripted into the army. Wrote short-lined poetry of despair and protest containing echoes of Byronic romanticism. $(\mathrm{H})$ 
Shchepkin, M.S. (1788-1863). Character actor. Outstanding in both comedy and tragedy. Instrumental in helping to create the realistic school of acting characteristic of the Maly Theatre.

Sollogub, Count A.A. (1813-82). Author. Best known for Tarantass (1845), a witty and observant travelogue-style work with interpolations commenting on urban and provincial life. $(\mathrm{R})$

Stankevich, N.V. (1813-40). Philosopher. Best known for attracting a peer group to his 'circle' in early 1830 s to discuss Schelling, Kant and Fichte. $(\mathrm{H})$

Strakhov, N.N. (1828-96). Essayist and critic. Friend and correspondent of both Tolstoi and Dostoevskii, he composed valuable critiques of Crime and Punishment and War and Peace. $(\mathrm{H})$

Sumarokov, A.P. (1718-77). Poet and dramatist. Author of copious works in several genres, particularly the drama. Generally, if not always fairly, regarded as little more than an imitator of foreign models. $(H, R)$

Zhukovskii, V.A. (1783-1852). Poet and translator. Notable as the initiator of Romanticism with translations of Thomas Gray, Schiller, Byron, etc., but he was also an exponent of the ballad and the meditative elegy. Very influential in pleading the case for fellow poets and writers in his role as a courtier. $(H, R)$ 



\section{Select Bibliography}

(M. = Moscow; P-grad $=$ Petrograd $;$ L. = Leningrad; Spb. $=$ St Petersburg; O.U.P. $=$ Oxford University Press; C.U.P. $=$ Cambridge University Press)

Aikhenval'd, Iu., Spor o Belinskom, M., 1914.

Andrew, J., Writers and Society During the Rise of Russian Realism, London and New Jersey, 1980.

Annenkov, P.V., Literaturnye vospominaniia, Gos. izd. khud. lit., 1960; M., 1983.

Bayley, J., Pushkin: A Comparative Commentary, C.U.P., 1971.

Belinskii: Pis'ma (3 Vols.), pod red. E.A. Liatskogo, Spb., 1914.

Belinskii, V.G., Sobranie sochinenii (3 Vols.), pod red. F.M. Golovenchenko, M., 1948.

, Polnoe sobranie sochinenii, Vols. I-XIII, M., 1953-9.

V.G. Belinskii $v$ vospominaniiakh sovremennikov (sostaviteli: A.A. Kozlovskii i K.I. Tiun'kin), M., 1977.

Belinskii: Istorik i teoretik literatury, sbornik statei, M.-L., 1949.

Berdyaev, N.A., The Russian Idea, London, 1947.

Berezina, V.G., Belinskii i voprosy istorii russkoi zhurnalistiki, L., 1973. , Etiudy o Belinskom, Spb., 1991.

Berlin, I., Russian Thinkers, London, 1978.

Blagoi, D.D. et al., Belinskii i sovremennost', M., 1964.

Botkin, V.P., Literaturnaia kritika - publitsistika - pis'ma, M., 1984.

Bowman, H.E., Vissarion Belinskii, 1811-1848: A Study in the Origins of Social Criticism in Russia, Harvard U.P., 1954.

Brown, E.J., Stankevich and his Moscow Circle, Stanford U. P., 1966.

Carr, E.H., Michael Bakunin, London, 1937.

The Romantic Exiles, London, 1968.

Chernyshevskii, N.G., Ocherki gogolevskogo perioda russkoi literatury, M., 1958. 
Cornwell, N., The Life, Times and Milieu of V.F. Odoyevsky, London, 1986.

D'iakov, I. Ia., Mirovozzrenie V.G. Belinskogo, Amurskoe kn. izd., 1962. Dormandy, T., The White Death: A History of Tuberculosis, London, 1999.

Dostoevskii, F.M., Polnoe sobranie sochinenii v 30 tomakh, L., 1972-90. Egorov, B.F., Literaturno-kriticheskaia deiatel'nost' V.G. Belinskogo, M., 1982.

Fasting, S., V.G. Belinskij: Die Entwicklung seiner Literatur Theorie. I: Die Wirklichkeit ein Ideal, Scandinavian University Books, OsloBergen-Tromso, 1972.

Forsyth, J., 'Pisarev, Belinsky and Evgeny Onegin,' The Slavonic and East European Review (April, 1970), pp. 163-80

Frank, J., Dostoevsky: The Seeds of Revolution, 1821-1849, Princeton U.P. and London, 1972.

Ginzburg, Lydia, On Psychological Prose. Translated and edited by Judson Rosengrant. Foreword by Edward J. Brown. Princeton U.P., 1991.

Gogol', N.V., Polnoe sobranie sochinenii, Izd. Akad. nauk, 1940-52.

Hare, R., 'Vissarion Belinsky' in Pioneers of Russian Social Thought, O.U.P., 1951.

Herzen (Gertsen), A.I., Polnoe sobranie sochinenii, pod red. M.K. Lemke, vol. VI, P-Grad, 1919. , Sobranie sochinenii v 30 tomakh, M., 1954-65.

Illertskii, V.E., Istoricheskie vzgliady V.G. Belinskogo, Gos. izd. polit. lit., 1953.

Iovchuk, M., Belinskii: Ego filosofskie i sotsial'no-politicheskie vzgliady,

Gos. sots.-ekon. izd., 1939.

Ivanov-Razumnik, V.G. Belinskii, P-grad. 1918.

Karpenko, G, Iu., Vozvrashchenie Belinskogo, Samara, 2001.

Kelly, A., Mikhail Bakunin: A Study in the Psychology and Politics of Utopianism, O.U.P., 1982.

Kirpotin, V., Dostoevskii i Belinskii, izd. vtoroe, M., 1976.

Lampert, E., Studies in Rebellion, London, 1957.

Lavretskii, A., Estetika Belinskogo, M., 1959.

Layton, S., Russian Literature and Empire: Conquest of the Caucasus from Pushkin to Tolstoy, C.U.P., 1994.

Leatherbarrow, W.J., and Offord, D.C., eds., A Documentary History of Russian Thought from the Enlightenment to Marxism, Ardis, Ann Arbor, 1987.

Literaturnoe nasledstvo, 55-57, M., 1948-51. 
Magarshack, D., Turgenev's Literary Reminiscences, London, 1959.

Manuilov, V.A., and Semenova, G.P., Belinskii v Peterburge, L., 1979.

Margolis, D., Kniga N.V. Gogolia 'Vybrannye mesta iz perepiski $s$ druz'iami': Osnovnye vekhi istorii vospriiatiia, Spb., 1998.

Mezentsev, P.A., Belinskii: Problemy ideinogo razvitiia i tvorcheskogo naslediia, M. 1957.

—, Belinskii i russkaia literatura, M., 1965.

Mordovchenko, N., Belinskii i russkaia literatura ego vremeni, M.-L., 1950.

Nechaeva, V.S., V.G. Belinskii: Nachalo zhiznennogo puti i literaturnoi deiatel'nosti 1811-1830, Izd. Akad. nauk, 1949.

_ V.G. Belinskii: Uchenie v universitete i rabota v 'Teleskope' $i$ 'Molve' 1829-1836, izd. akad. nauk, 1954.

1961.

, V.G. Belinskii: Zhizn' i tvorchestvo 1836-1841, izd. akad. nauk.,

, V. G. Belinskii: Zhizn' i tvorchestvo 1842-1848, izd. 'Nauka', 1967.

Offord, D., Portraits of early Russian liberals, C.U.P., 1985.

, 'Vissarion Grigor'evich Belinskii' in Russian Literature in the Age of Pushkin and Gogol: Prose, ed. Christine A. Rydel, (Dictionary of Literary Biography, vol. 198), Bruccoli Clark Layman, Gale Research, Detroit, Washington D.C., London, 1999, pp. 24-53.

Panaev, I.I., Literaturnye vospominaniia, Gos. izd. khud. lit., 1950.

Panaeva, A.I. (Golovacheva), Vospominaniia, M., 1972.

Pisarev, D.I., Izbrannye sochineniia v dvukh tomakh, M., 1935.

Poliakov, M., Vissarion Belinskii: Lichnost' - idei - epokha, M., 1960. -, Poeziia kriticheskoi mysli, M., 1968.

Plekhanov, G.V., 'Vissarion Grigor'evich Belinskii (1810-1848)', Istoriia russkoi literatury XIX veka, pod red. D.N. Ovsianiko-Kulikovskogo, Vol. 2, M., 1909, pp. 227-69.

—, V.G. Belinskii: sbornik statei, M.-P-grad, 1923.

- Estetika i sotsiologiia iskusstva. V dvukh tomakh, M., 1978.

Proffer, C., ed. and trans., Letters of Nikolai Gogol', Michigan U.P., Ann Arbor, 1967.

Prokhorov, E.P., V.G. Belinskii, M., 1978.

Proktor, T., Dostoevsky and the Belinsky School of Literary Criticism, The Hague, 1969.

Pypin, A.N., Belinskii: Ego zhizn' i perepiska, Izd. vtoroe, Spb., 1908.

Randall, F.B., Vissarion Belinskii, Newtonville, 1987.

Remizov, P., Nekotorye velikie i poleznye istini ob igre v preferans, Spb.,

1843. 
Retsepter V., The Return of Pushkin's Rusalka, Pushkin State Theatre Centre, Spb., 1998; London, Angel Books, 1998. Translated by Antony Wood.

Shatz, M., 'Bakunin, Turgenev and Rudin,' The Golden Age of Russian literature and Thought, ed. Derek Offord, Macmillian, London, 1992, pp. 103-14.

Sobolev, P., Estetika Belinskogo, M., 1978.

Solov'ev, G.A., Esteticheskie idei molodogo Belinskogo, M., 1986.

Slavin, L., Neistovyi: povest'o Vissarione, M., 1973.

Stepanov, V.I., Filosofskie i sotsiologicheskie vozzreniia V.G. Belinskogo, Minsk, 1959.

Tal'nikov, D.L., Teatral'naia estetika Belinskogo, M., 1962.

Terras, V., Belinskii and Russian Literary Criticism: The Heritage of Organic Criticism, Madison, 1974.

—, 'Belinsky the journalist and Russian literature' in Literary Journals in Imperial Russia, ed. Deborah A. Martinsen (Columbia University), C.U.P., 1997, pp. 117-28.

Tihonova, E. Iu., Mirovozzrenie Molodogo Belinskogo, M., 1998.

-, Belinskii v spore so slavianofiliami, M., 1999.

Vengerov, S.A., Ocherki po istorii russkoi literatury, Spb., 1907. 


\section{Index}

(limited to names of persons mentioned in the text and notes)

Aksakov, I.S., 140

Aksakov, K.S., 75

Alexander the Great, 12

Alexander I, 12

Annenkov, P.V., 2, 4, 6, 44, 63, $133-4,142,145,148-50,154$, $157,159,161,163,164-5,173$ Arendt, A. F., 139

Armance, $90-4$

Avvakum, P., Archpriest, 153

Bakunin, M. A. ('Michel'), 5, 26, 31, $33-4,36-9,41,52-4,79-80,86$, $161,165-6$

Bakunin, N. A., $63,65,79-80$

Bakunina, A. A., 26, 34, 37

Bakunina, L. A., 37, 41

Bakunina, T. A., 26, 34, 41

Balzac, H. de, 23

Baratynskii, E. A., 76

Barbes, A., 172

Batiushkov, K. N., 111

Bayley, J., 123

Belinskaia, M. V., see Orlova, M. V.

Belinskii, K. G., 17

Belinskii, N. T., 10

Berdiaev, N. A., 55

Berkh, A. M., 138, 172, 175

Berkh, M., 138

Berlin, I., 2, 3, 190

Blanqui, A., 172
Botkin,V. S., 5-6, 11, 26, 35, 39, 52, $54,56,64,71,73,79,82,86$, 90-4, 101, 106-7, 109, 142, 145, $148,160,163-5,173$

Bowman, H. E., 5, 20, 57, 83

Brown, E. J., 18

Bulgarin, F. V., 131

Byron, Lord G. G. N., 1, 15, 23, 64, $69,76,85,97,110$

Carr, E. H., 54

Catherine the Great, 20, 82

Chaadaev, P. Ia., 23, 26

Charpiot, Mme., 92-3, 102

Chernyshevskii, N. G., 39, 66-7, 176,182

Comte, A., 145-6, 149

Cooper, F., 40, 56, 69

Cornwell, N., 146

Dal', V. I., 171

Dante, 118

Derzhavin, G. R., 12, 20-1, 72, 82, 108, 111

Dickens, C., 108, 164

Dmitriev, I. I., 12

Dobroliubov, N. A., 144, 176, 182

Dormandy, T., 187

Dostoevskii, F. M., 1, 6-7, 22, 51, 54, $64,72,113,126-31,136-7,142-3$, $145,152,165,171-2,180,185$ 
Dostoevskii, M. M., 136

Druzhinin, A. V., 117, 171

Fasting, S., 5, 48

Feuerbach, L. A., 142, 182

Fichte, J. G., 3, 34-5, 182

Fonvizin, D. I., 40, 44-5

Forsyth, J., 109

Frank, J., 130, 152

Frederic, 161-2

Galakhov, A.D., 176

Ginzburg, L., 22, 43

Glinka, F., 46

Godwin, W., 40

Goethe, J. W. von, 23, 38, 46-7, 69, $85,110-1,114,118,123$

Gogol, N. V., 1, 7, 23-5, 44-5, 48-9, $51,71,73-7,88,94,105-6$, $114-5,119,124,126,131-2,135$, $140-1,145-57,159-60,162-4$, $166-70,173,180,184$

Goncharov, I. A., 6, 109, 133, 142, 176-7, 186-7

Gorbunov, 81

Gorchakov, V. P., 116

Grech, N. I., 77

Griboedov, A. S., 21, 44-5, 47-9, 54, 119

Grigorovich, D. V., 127-8, 171

Hegel, G. W. F., 2-3, 7, 28, 33-5, $38-9,43,54-5,59,64,86,182$

Heine, H., 23

Herzen, A. I., 1, 6, 9-10, 18-19, 34, 52, $71-2,86,90-1,126,130,132-3$, $135,139-40,145,154,156$, $159-60,165,170,173,180,186$

Hogarth, W., 106-7

Homer, 40, 75, 77, 110

Hugo, V., 23, 85

Ivanov, D. P., 13, 27

Ivanov-Razumnik, R. V., 1 Ivan the Terrible, 60
Kantemir, A. D., 108

Karamzin, N. M., 12, 20, 82, 121

Katkov, M. N., 39, 48, 52-3, 67

Kavelin, K. D., 159, 163

Kelly, A., 34, 54

Ketcher, N. K., 66, 103, 126, 176

Khomiakov, A. S., 108

Kirpotin, V., 185

Kol'tsov, A. V., 40, 80

Kotoshikhin, G. K., 140

Kraevskii, A. A., 47, 51, 56, 73, 76, 80, $86,88,96,101,125,133,163,173$

Krylov, I. A., 21, 108, 132

Lamartine, A. de, 85

Lavretskii, A., 48

Layton, S., 61, 116

Leatherbarrow, W. J., 151

Lemke, M. K., 10

Lenin, V. I., 5

Lermontov, M. Iu., 7, 26, 55-6, $59-61,67,73-4,116,119-20$, 184-5

Liatskii, E. A., 16, 37, 89

Lomonosov, M. V., 20, 82, 132

Luther, M., 64

Lytton, B., 24

Maikov, A. N., 76, 130

Malia, M., 161

Manuilov, V. A., 129, 176

Margolis, Iu. D., 154

Marx, K., 126, 149-50

Menzel, W., 43-4, 46

Michelangelo, 160

Mochalov, P., 29, 173, 189

Molière, 23, 49

Mozart, A. W., 123

Musorgskii, M., 121

Nadezhdin, N. I., 17-18, 22-3, 26

Nechaev, S., 38 
Nechaeva, V. S., 5, 10, 13, 20, 23, $25,27,44,52,65-6,84,89,107$, $138,172-3$

Nekrasov, N. A., 81, 127-8, 130, $133,142,173$

Nicholas I, 12, 61, 180-1

Nikitenko, A. V., 68, 142

Nikon, Metropolitan, 153

Odoevskii, V. F., 130, 146

Offord, D., 4, 33, 117, 151, 159

Ogarev, N. P., 54

Ogareva, M., 52, 54

Olga, 137, 146, 173-4, 176, 188

Orlova, A. V., 88, 93, 95, 109, 125, 147, 173-6

Orlova, M. V. ('Marie'), 72-3, 86-90, 92-103, 106-7, 109, $125-6,135-7,147,160,172-6$

Ovsianiko-Kulikovskii, D. N., 183

Palm-Durov (Circle), 152

Panaev, I. I., 51-2, 56, 65, 130, 142, 175

Panaeva, A. I., 103

Pantusov, N. V., 172

Peter the Great, 7, 28-9, 46, 51, 67, $115,118,121-2,143,161,163$, $166,179,182,184-5$

Philip II, 55

Pisarev, D. I., 109, 110-1, 114-5, 121,181

Plekhanov, G. V., 144, 182-3

Pogodin, M. P., 71

Polevoi, N. A., 29

Polezhaev, A. I., 76, 156

Poliakov, A. S., 44

Poliakov, M., 66, 84

Potêmkin, G. A., 138

Proffer, C., 155

Proudhon, P.-J., 142, 149-50

Prozorov, P. I., 15

Pushkin, A. S., 2, 7, 12, 20-1, 25, $35-6,39,44-5,51,58,60-1,67$,
$72-6,82,87,105,109-24,131$, $133,159,166,181,184-5,188$

Randall, F. B., 188

Raphael, S., 159

Remizov, P., 81

Retsepter, V., 123

Roetscher, H. I., 39, 40, 48, 57, 67

Rubens, P. P.,159

Saint-Simon, Comte de, 65,67

Samarin, Iu. F., 163

Sand, G., 65, 67, 91, 95, 140, 142

Satin, N. M., 27

Schelling, F. W. J., 3, 18, 34, 146

Schiller, F., 14, 23, 38, 69, 85, 110

Scott, W., 23, 56, 69, 75

Semeneva, G. P., 129, 176

Senkovskii, O. I., 77

Shakespeare, W., 7, 14, 23-4, 29-30, $38,40,110,112,122-3,168-9$, 185,189

Shatz, M., 33

Shchepkin, D. M., 162

Shchepkin, N. M., 176

Shchepkin, M. S., 43-4, 135, 137-9, 189

Shelley, P. B., 157

Shevchenko, T., 164

Shevyrev, S.P., 71

Shmakov, I., 139

Sidonskii, Archpriest, 91

Slavin, L., 2

Smirnova, A. O., 140-1

Soldatenkov, M. K., 176

Sollogub, V. A., 130, 132

Sophocles, 76

Sresnevskii, I., 44

Stael, Mme de, 111

Stalin, J. V., 2, 5, 190

Stankevich, N. V., 18, 33, 37, 40-1, 74

Stirner, M., 150

Strakhov, N. N., 126-7 
Sue, E., 107-8

Sumarokov, A. P., 12

Terras, V., 2, 5, 83, 183-4

Tirat (?), de Melmor, 160

Tolstoi, L. N., 7, 112

Turgenev, I. S., 1, 6, 33-4, 44, 70, $80-1,101,117,125-6,130-1$, $141,146-9,152,160-1,165$, $171-3,176-7,179-82$

Vengerov, S. A., 13

Viardot, L., 131, 148

Viardot, P., 148
Vigny, A. de, 23

Vladimir, 147

Voltaire, 10, 12, 27, 64, 156, 165, 189

Werder, K., 33

Wilson, E., 180

Wilson, J., 123

Wood, A., 123

Zemplin, Dr, 149

Zhukovskii, V. A., 21, 46, 72, 86-7, 111

Zolotusskii, I. P., 154 





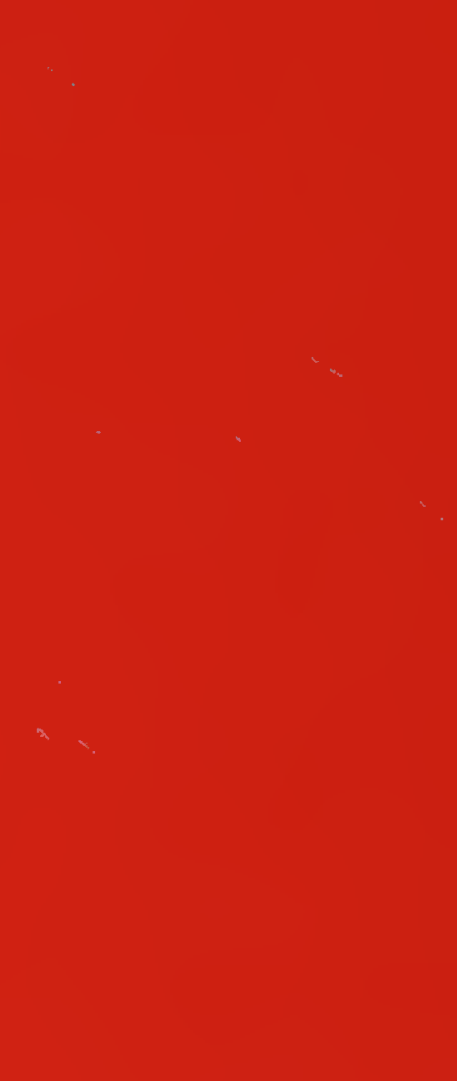

